ERDÉLYI TUDOMÁNYOS FÜZETEK

263

W. KOVÁCS ANDRÁS

\title{
AZ ERDÉLYI VÁRMEGYÉK KÖZÉPKORI ARCHONTOLÓGIÁJA
}

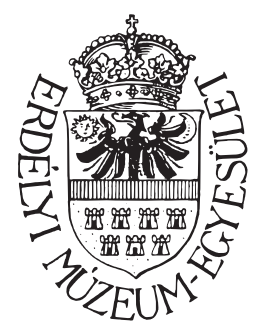

Kolozsvár, 2010 
Készült

a Magyar Tudományos Akadémia

Határon Túli Magyar Tudományosságért Ösztöndíjprogram

támogatásával

az Erdélyi Múzeum-Egyesület kolozsvári Kutatóintézetében.

Az Erdélyi okmánytár IV. kötetének előkészítését

az Erdélyi Múzeum-Egyesület,

a Magyar Tudományos Akadémia

Határon Túli Magyar Tudományosságért Ösztöndíjprogram,

a Magyar Országos Levéltár és az

Országos Tudományos Kutatási Alapprogram K 78324 TRT sz. pályázata támogatja.

A nyomtatást a Szülőföld Alap

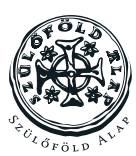

támogatta.

(C) Erdélyi Múzeum-Egyesület, 2010

Felelős kiadó

BIRÓ ANNAMÁRIA

Lektorálta

HEGYI GÉZA

Müszaki szerkesztés, tördelés

BODÓ ZALÁN

Nyomdai munkálatok

Napoca Star, Kolozsvár

Descrierea CIP a Bibliotecii Naționale a României

KOVÁCS, ANDRÁS W.

Az erdélyi vármegyék középkori archontológiája / W. Kovács András. Cluj-Napoca: Societatea Muzeului Ardelean, 2010

Bibliogr.

Index

ISBN 978-606-8178-08-0

94(498.4) 


\section{TARTALOM}

Bevezető.

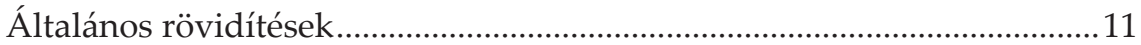

A könyvészeti források rövidítései ................................................................ 13

A felhasznált kéziratos (levéltári és kézirattári)

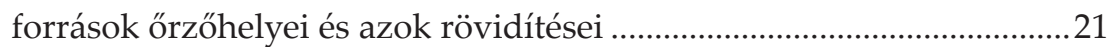

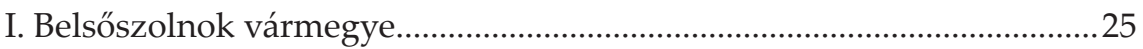

II. Doboka vármegye ......................................................................................

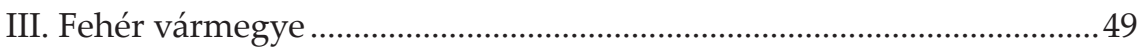

IV. Hunyad vármegye ................................................................................ 55

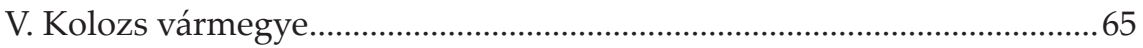

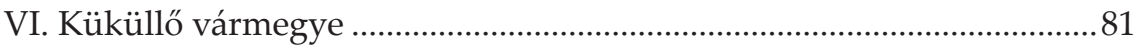

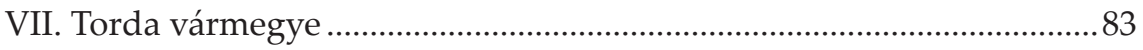

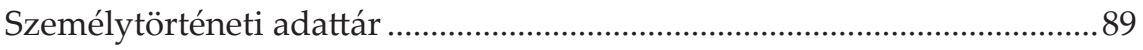

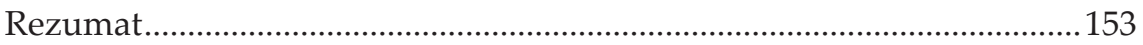

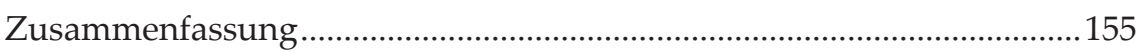


EME 


\section{EME}

\section{BEVEZETŐ}

Az erdélyi vármegyék középkori archontológiája a hét erdélyi vármegye (Belsőszolnok, Doboka, Fehér, Hunyad, Kolozs, Küküllő, Torda) ismert tisztségviselőinek - az ispánok, a megyénkénti két szolgabíró és a vármegyei jegyző - neveit és hivatalviselésük időhatárait tartalmazza 1541 végéig. Ezen archontológiai segédlet az Erdélyi okmánytár tervezett következő köteteinek előkészítési munkálatai során állt össze; célja az, hogy az erdélyi vajdaság igazgatásának, illetve az erdélyi vármegyei nemesség tanulmányozását segítse. Minthogy egy országrésznyi területről van szó, remélhetőleg nem csak lokális kutatói igényt elégít ki. ${ }^{1}$

Az összeállítás - természetesen - nem előzmény nélküli. A 14. századra Wertner Mór állított össze archontológiai listákat (az erdélyi megyék Árpád-kori ispánjairól és 14. századi ispánjairól és szolgabíráiról is). ${ }^{2}$ Erdélyi archontológiai adatokat Csánki Dezső is szép számmal közölt, elszórtan, történeti földrajzának V. kötetében. ${ }^{3}$ 1996-ban Engel Pál kiadta a középkori Magyarország 1301-1457 közötti archontológiáját. Ez utóbbi munka tartalmazza az erdélyi vármegyék ispánjait is a jelzett korszakból. ${ }^{4}$ Mindazonáltal az adatgyüjtést nem volt célszerü csak 1458-tól elkezdeni. Egyrészt az 1301-1457 közötti időszakból is kerültek elő ispánokra vonatkozó újabb archontológiai adatok, másrészt úgy tűnt, hogy az ispánokat

\footnotetext{
${ }^{1}$ A középkori Magyarország vármegyéiről megjelent legújabb összefoglalás, az ide tartozó szakirodalom áttekintésével együtt: Tringli István: Megyék a középkori Magyarországon. In: Honoris causa. Tanulmányok Engel Pál tiszteletére. Bp.-Piliscsaba 2009 (Társadalom- és müvelödéstörténeti tanulmányok 40. sz. - Analecta Medievalia III). 487-518.

${ }^{2}$ Wertner Mór: Árpádkori megyei tisztviselők (I-III). In: TTár 20/1897. 439-486, 653-679. 21/1898. 105-133; uő: Újabb adalékok az Árpád-kori megyei tisztviselők ismeretéhez (I-II). In: TTár 6/1905. (Új folyam) 42-61, 164-184; uő: Adalékok a XIV. századbeli magyar világi archontológiához (I-IV. közlemény). In: TTár 7/1906. (Új folyam) 583-609; 8/1907. (Uj folyam) 1-69, 161-198, 327-354; Wertner Moritz: Siebenbürgens Komitatsbeamtenkörper bis zum Ende des vierzehnten Jahrhunderts. In: Archiv des Vereins für siebenbürgische Landeskunde 29 (1899). 236-311.

${ }^{3}$ Csánki V. passim.

${ }^{4}$ Engel: Arch. I. 246-251.
} 
és a vármegyék szolgabíráit érdemes együtt bemutatni. E két tisztség viselése között ugyanis volt átjárás: szolgabírákból lettek ispánok és fordítva. A megyésispánok többségének ezen a szinten megrekedt a karrierje, és főképpen a 15. században - az országos politikához meglehetősen kevés közük volt, legföljebb Erdélyben volt szerepük. (Mindez egybecseng azzal a megállapítással, hogy az erdélyi ispánok rangja - minthogy a 14. század elejétől őket nem a király, hanem az erdélyi vajda nevezte ki familiárisai köréből - alacsonyabb volt magyarországi társaikénál és voltaképpen alispánoknak tekinthetők.) A szolgabírák számbavételét az is indokolta, hogy - noha nem volt politikai szerepük - legalábbis részben ugyanazokból a helyi, szerény vagyonú, de a vármegyéjükben hangadó családokból kerültek ki, mint az ispánok.

Jegyzékemben feltüntettem egy tisztség összes előfordulását (tehát nemcsak az elsőt és utolsót), ugyanis viszonylag ritkán, leginkább az ispánok tisztségviselése esetében ismerünk egynél több említést. A hivatkozott források napi keltezése után ezek levéltári őrzőhelye vagy a közlés helye szerepel.

Az összeállítás végén található az archontológiai listákban előforduló személyek betürendes felsorolása. Ugyanitt reájuk vonatkozó egyéb adatokat is megtalál az olvasó. E személytörténeti adattár tartalmazza a javasolt azonosítások magyarázatát is. ${ }^{5} \mathrm{Az}$ általam megállapított azonosító nevek („,családnevek”) az archontológiai részben szögletes zárójelbe kerültek. A magyarországi, Mohács előtti iratanyag ismert egyoldalúsága miatt - az oklevelek nagy része leginkább birtokjogi adatokat tartalmaz - az ispáni és szolgabírói tisztséget viselőkről szinte kizárólag csak annyit tudunk meg, hogy hol és milyen jogon voltak birtokaik. Olykor ügyvédként, királyi vagy vajdai emberként tünnek elő az oklevelekben, de általában szerény, megyék keretén belüli életpályákat futnak be. Az esetleg viselt egyéb tisztségeket ugyanitt, az összeállítás végén található Személytörténeti adattárban találja meg az olvasó.

Az összegyűjtött archontológiai adatok elsöprő többsége a vármegyei hatóságok által kibocsátott oklevelekből származik, melyek összegyűjtését (levéltári jelzeteik megállapítását) könnyűszerrel el lehetett végezni a Ma-

\footnotetext{
${ }^{5}$ A tisztséget viselők meghatározása, egy bizonyos családhoz kötése ugyanis nem bizonyult mindig egyszerű feladatnak. Ha csak a keresztnevet említik az oklevelek (pl. Saul magister, Hunyad vm. ispánja, 1365), közelebbi meghatározása nem volt lehetséges. Máskor, ha nemcsak a tisztségviselőnek, hanem apjának a nevét is említi a megyei oklevél, nagy valószínűséggel meghatározható volt a kiléte (pl. Demeter fia: János - Doboka vm. szolgabírája 1350-1361 között - minden bizonnyal azonos azzal a Galaci Demeter fiával: Jánossal, aki ekkoriban ebben a vármegyében több alkalommal királyi vagy vajdai kiküldött). Olykor azonban, noha vármegyei oklevélből ismert ugyan a család- és keresztnév is, bizonyosan nem volt megállapítható, hogy melyik - azonos nevü - családhoz tartozik az illető (pl. Nagy Ambrus, Belsőszolnok vm. ispánja 1468-ban).
} 
gyar Országos Levéltár Mohács előtti gyűjteménye elektronikus adatbázisának segítségével. ${ }^{6}$ Meglehetősen ritka az az eset, amikor tanúkihallgatás alkalmával vagy birtokba iktatásnál a szomszédok felsorolásakor említik valakinek az ispáni vagy szolgabírói tisztségét. Az ispánokat az erdélyi vajda nevezte ki, de ezek a kinevezések általában szóban történtek. ${ }^{7}$ A kevés Árpád-kori archontológiai adat többsége királyi oklevelek méltóságsorából való. Minthogy a 14. század elejétől az erdélyi vármegyék ispánjai a mindenkori erdélyi vajda familiárisai, a Személytörténeti adattár általában csak abban az esetben említi ezt a viszonyt, ha arról konkrét okleveles említés ismert. ${ }^{8}$

Fehér vármegye ispáni tisztségét a mindenkori erdélyi alvajda viselte, viszont az archontológia és a névmutató is csak azoknak az alvajdáknak a nevét tartalmazza, akiknek ispáni minőségükben kiállított megyei oklevelét ismerjük. Megjegyzendő azonban, hogy mivel a MOL fentebb említett adatbázisa az erdélyi alvajdák által Fehér vármegyei ispánként és a két ottani szolgabíróval együtt kiadott okleveleket olykor megtévesztően alvajdai oklevélként regisztrálja, e vármegye ispánjainak és szolgabíráinak sorozata a későbbiekben még bővíthető lesz.

Egyelőre megoldhatatlan feladat maradt az 1526-1541 közötti megyei oklevelek hiánytalan átnézése is. A korszak iratairól ugyanis nem áll a rendelkezésünkre egy olyan, úgyszólván mindent számba vevő segédlet, amilyennel a Mohács előtti korszak okleveleiről rendelkezünk (a legtöbb családi levéltár esetében az 1526-1541 közötti iratokat nem emelték ki az illető levéltár egységeiből és nem tették időrendi sorrendbe). A Román Nemzeti Levéltár Kolozs Megyei Igazgatósága kezelésében levő Erdélyi Nemzeti Múzeum Levéltárának részét képező több gyűjtemény és családi levéltár e korszakból való iratait időrendbe helyezték, mások azonban a kutatás számára továbbra is hozzáférhetetlenek. Az átnézett fondok alap-

\footnotetext{
${ }^{6}$ Collectio diplomatica Hungarica. A középkori Magyarország digitális levéltára. Digital archives of medieval Hungary. A Magyar Országos Levéltárban (MOL) a Mohács előtti gyưjteményekhez 1874-2008 között készült levéltári segédletek és oklevelek elektronikus feldolgozása (DL-DF 4.3). Szerk. Rácz György. Bp. 2008. - Internetes kiadás (DL-DF 5.1): 2009. - A tisztségviselőkre vonatkozó adatok jó része is a digitális oklevélkatalógusban hozzáférhető regesztákból származik.

${ }^{7}$ Jelenleg csak két, ispáni kinevezéssel kapcsolatos oklevelet ismerünk. Szentgyörgyi Péter erdélyi vajda 1499. I. 1-jén értesíti Torda vármegye nemeseit és más rendű-rangú embereit, hogy új ispánokat nevezett ki és kéri, hogy nekik mindenben engedelmeskedjenek (DL 65442, idézi: Mályusz: Az erdélyi társadalom 31, 91, 117. jegyzet) és ugyanő 1525-ben Torda vm. nemességét értesíti, hogy a vm. ispánjává Gerendi László helyett Barcsai Pált nevezte ki (ENMLt, iktári Bethlen cs 1t, 1525. I. 2., DF 255125).

${ }^{8}$ Az erdélyi vajdák és alvajdák hivatalviselését lásd: Engel: Arch. I. 11-15; Fügedi Erik: $A$ XV. századi magyar arisztokrácia mobilitása. Bp. 1970. (Történeti statisztikai kötetek). 108-109; Pall Francisc: Voievozii şi vicevoievozii Transilvaniei. In: Documente privind istoria Romîniei. Introducere. I. Bucureşti 1956. Anexa II. 497-505.
} 
ján a kutatónak az a benyomása támad, az 1526-1541 közötti korszakból a korábbi évtizedekhez képest meglehetősen kevés irat maradt fenn. Ezek között pedig elvétve található megyei oklevél. Ezek archontológiai adatait kár lett volna kihagyni az összeállításból, azonban az itt jelzett fogyatékosságot e füzet használói szem előtt kell hogy tartsák. Az 1540-1690 közötti korszakra az erdélyi vármegyék főispánjairól Lázár Miklós - sajnos igen gyéren jegyzetelt - összeállítása áll a kutatás rendelkezésére. ${ }^{9}$

Az egyes megyékre vonatkozó adatok felsorolása előtt az illető megyék archontológiáját vagy történeti földrajzát tárgyaló korábbi fontosabb munkák bibliográfiai adatai találhatók.

A kézirat kényszerü újratördelése közben jelent meg Zsoldos Attila Magyarország világi archontológiája 1000-1301 címü munkája, amely az erdélyi vármegyék - továbbá az itteni királyi vagy királynéi uradalmak, illetve ispánságok (Beszterce, Brassó, Hátszeg, Radna, Szeben) és az ekkor még osztatlan Szolnok vármegye - tisztségviselőit is tartalmazza (i. m. 137, 145, 158, 187, 204-205, 209-211). A megyei archontológiából az Árpád-kori megyésispánok adatait ennek ellenére sem töröltük, hanem - ahol szükségesnek mutatkozott - Zsoldos kötetének pontosabb azonosításait, az erre történő hivatkozással, átvettük.

\footnotetext{
${ }^{9}$ Lázár Miklós: Erdély főispánjai 1540-1711. In: Sz 21/1887. 5. sz. 400-426 (Fehér); 6. sz. 518-528; 7. sz. 610-625; 9. sz. 700-715 (Kolozs); 22/1888. 1. sz. 33-41; 3. sz. 242-251; 4. sz. 334-348 (Küküllő); 5. sz. 426-434; 6. sz. 505-522 (Torda); 7. sz. 622-637; 8. sz. 730-739 (Doboka); 10. sz. 911-931 (Belsőszolnok); 23/1889. 1. sz. 30-41 (Hunyad); 2. sz. 131-147 (Kővár-vidék); 3. sz. 229-237 (Fogaras-vidék). - Különlenyomat: Bp. 1889. - Kiegészítések hozzá: Torma Károly: Adalék gróf Lázár Miklós „Erdély főispánjai (1540-1711.)” czímű közleményéhez. In: Sz 23/1889. 4. sz. 311-324. Lásd még: Koncz József: Hunyadvármegye főispánjai (1540-1711). In: Hunyadvármegyei Történelmi és Régészeti Társulat Évkönyve 11/1900. Déva 1900. 145-147.
} 


\section{ÁLTALÁNOS RÖVIDÍTÉSEK}

$t=$ meghalt

a. = ante (keltezésben)

$\mathrm{AD}=$ Arad vm.

$\mathrm{AJ}=$ Abaúj vm.

$\mathrm{BAR}=$ Baranya vm.

BCs = Bács vm.

BÉ $=$ Békés vm.

$\mathrm{BI}=$ Bihar vm.

$\mathrm{BSz}=$ Belsőszolnok vm.

$\mathrm{BSD}=$ Borsod vm.

cs = család, $-\mathrm{i}$

CsD = Csanád vm.

(d) = dictus

$\mathrm{DO}=$ Doboka vm.

e. = elött

eml. = említés, említve

f. = feria (és alakjai; keltezésben)

$\mathrm{FH}=$ Fehér vm.

GM = Gömör vm.

gyüjt. = gyüjtemény, -e

$\mathrm{HD}=$ Hunyad vm.

hitb. = hitbizományi

HS $=$ Heves vm.

$\mathrm{KA}=$ Kraszna vm.

k. = körül

kápt. = káptalan

$\mathrm{KK}=$ Küküllő vm.
$\mathrm{KL}=$ Kolozs vm.

konv. = konvent

$\mathrm{KR}=$ Krassó vm.

$\mathrm{KSz}=$ Középszolnok vm.

lt = levéltár, levéltára

mlt = magánlevéltára

nb. = nemzetségbeli

nemz. $=$ nemzetségi

$\mathrm{MM}=$ Máramaros vm.

$\mathrm{NO}=$ Nógrád vm.

$\mathrm{Ny}=$ Nyitra vm .

p. = post (keltezésben)

$\mathrm{PO}=$ Pozsony vm.

sz. = szám

SzR = Szatmár vm.

$\mathrm{TC}=$ Turóc vm.

$\mathrm{TD}=$ Torda $\mathrm{vm}$.

$\mathrm{TO}=$ Tolna $\mathrm{vm}$.

$\mathrm{TS}=$ Temes vm.

u. = után

$\mathrm{UG}=$ Ugocsa vm.

uo. = ugyanott

uö = ugyanő

vm. = vármegye

$\mathrm{ZD}=$ Zaránd vm.

$\mathrm{ZN}=$ Zemplén vm. 
EME 


\section{EME}

\section{A KÖNYVÉSZETI FORRÁSOK RÖVIDÍTÉSEI}

AcadRomMemSecțIst. Seria III. = Academia Română. Memoriile secțiunii istorice. Seria III.

Tom. XVIII (1935-1936). 215225: Sacerdoțeanu, Aurelian: Două acte hațegane şi unul vâlcean.

Amlacher: Broos $=$ Urkundenbuch zur Geschichte der Stadt und des Stuhles Broos bis zum Übergang Siebenbürgens unter Erbfürsten aus dem Hause Österreich 1690. Hg. Albert Amlacher, Hermannstadt 1879.

AOkl = Anjou-kori oklevéltár. Documenta res Hungaricas tempore regum Andagavensium illustrantia 1301-1387. I-XV, XVII, XIX-XX, XXIII-XXVII, XXXI. Szerk. Kristó Gyula, Blazovich László, Géczi Lajos, Almási Tibor, Kőfalvi Tamás, Tóth Ildikó, Makk Ferenc, Piti Ferenc, Sebők Ferenc. Bp.Szeged 1990-2007.

ArhIstRom $=$ Arhiva Istorică a României. Serie nouă. Bucureşti I-. 2004-.

1/2004. 1. sz. Buc. 2004. 27-74: Diaconescu, Marius: Documente medievale transilvă- nene din arhivele maghiare (1340-1350).

2/2004. 2. sz. Buc. 2004. 1-28:

Diaconescu, Marius: Documente din arhiva conventului din Cluj-Mănăştur referitoare la comitatul Dăbâca (cista comitatus Doboka) (1376-1399).

3/2004. 1. sz. Buc. 2005. 1-49:

Documente din arhiva conventului din Cluj-Mănăştur referitoare la comitatul Cluj (cista comitatus Colosiensis) (1376-1399).

ÁÚO = Codex diplomaticus Arpadianus continuatus. Árpádkori új okmánytár. Kiad. Wenzel Gusztáv. I-XII. Bp. 1860-1874. (Monumenta Hungariae Historica. Diplomataria. Magyar Történelmi Emlékek. Első osztály: Okmánytárak. VI-XIII, XVII-XVIII, XX, XXII).

BánfOkl = Oklevéltár a Tomaj nemzetségbeli losonczi Bánffy család történetéhez. Szerk. Varjú Elemér, Iványi Béla. I-II. (A Tomaj nemzetségbeli losonczi Bánffy család története). Bp. 1908-1928. 
Berger: Regesten = Berger, Albert: Urkunden Regesten aus dem Archiv der Stadt Bistritz in Siebenbürgen. I-II (1203-1570). Aus dem Nachlass herausgegeben von Ernst Wagner. Köln-Wien 1986; III. (1571-1585). Begründet von Albert Berger. Mit Ioan Dordea, Ioan Drăgan und Konrad G. Gündisch herausgegeben von Ernst Wagner. Köln-Weimar-Wien 1995. (Schriften zur Landeskunde Siebenbürgens. Bd. 11/I-III.).

Cat. font. $=$ Catalogus fontium historiae Hungaricae aevo ducum et regum ex stirpe Arpad descendentium ab anno Christi DCCC usque ad annum MCCCI. I-III. Collegit Albinus Franciscus Gombos. Budapestini 1937-1938.

Cercetări Istorice $=$ Cercetări Istorice. Buletinul seminarului de istoria românilor al Universității din Iaşi. [1943-tól: Studii şi cercetări istorice. Buletinul Institutului de Istorie Națională]. I-XX. Iaşi 1925-1947.

10-12/1934-1936. Nr. 1. 3-61:

Minea, Ilie: Din istoria unui cnezat ardelean.

CDHung $=$ Codex diplomaticvs Hungariae ecclesiasticvs ac civilis. Studio et opera Georgii Fejér. Tom. I-XI. Budae 1829-1844.

CDTrans = Codex diplomaticus Transsylvaniae. Diplomata, epistolae et alia instrumenta litteraria res Transsylvanas illustrantia. Erdélyi okmánytár. Oklevelek, levelek és más írásos emlékek Er- dély történetéhez. I. (1023-1300). Bevezető tanulmánnyal és jegyzetekkel regesztákban közzéteszi Jakó Zsigmond. Bp. 1997. II. (1301-1339). Jegyzetekkel regesztákban közzéteszi Jakó Zsigmond. Bp. 2004. III. (1340-1359). Regesztákban jegyzetekkel közzéteszi Hegyi Géza és W. Kovács András közreműködésével Jakó Zsigmond. Bp. 2008. (A Magyar Országos Levéltár Kiadványai. II: Forráskiadványok 26, 40, 47.).

Csánki = Csánki Dezső: Magyarország történelmi földrajza a $\mathrm{Hu}$ nyadiak korában. I-III, V. Bp. 1890-1913. (Hunyadiak kora Magyarországon. Gr. Teleki József művének folytatása gyanánt. VIVIII, IX.c).

Dani = Dani, Ioan: Anton cel Mare de la Buda în lumina unui document din 1435. In: Sub semnul lui Clio. Omagiu acad. prof. Ştefan Pascu. Cluj 1974. 317-325.

DRH C. = Documenta Romaniae Historica, C. Transilvania. Întocmit de Belu, Sabin - Dani, Ioan, Răduțiu, Aurel - Pervain, Viorica - Gündisch, Konrad G. - Rusu, Adrian - Andea, Susana - Gross, Lidia - Dincă, Adinel. X-XV. (1351-1380). Buc. 1977-2006.

DocVal = Documenta historiam Valachorum in Hungaria illustrantia usque ad annum 1400 p. Christum. Ed. Antonius Fekete Nagy et Ladislaus Makkai. (Etudes sur l'Europe Centre-Orientale. Ostmitteleuropäische Bibliothek nr. 29). Budapestini 1941. 
EM = Erdélyi Múzeum. Az Erdélyi Múzeum-Egyesület Bölcselet-, Nyelv- és Történettudományi Szakosztályának kiadványa. I-. Kv 1874-.

67/2005. 78-85: W. Kovács András: Szécsényi Tamás erdélyi vajda familiárisairól. (Néhány kiegészítés az Archontológiához).

EMOkl = Szabó Károly: Az Erdélyi Múzeum eredeti okleveleinek kivonata (1232-1540). Bp. 1889. (Klny a TTár 1889-1890. évfolyamából).

Engel: Alvajda = Engel Pál: Néhány XIV. századi erdélyi alvajda származása. In: Emlékkönyv Jakó Zsigmond születésének nyolcvanadik évfordulójára. Szerk. Kovács András, Sipos Gábor és Tonk Sándor. Kolozsvár 1996. 176-186.

Engel: Arch. = Engel Pál: Magyarország világi archontológiája 13011457. I-II. Bp. 1996. (História Könyvtár. Kronológiák, adattárak 5.).

Engel: Gen. = Engel Pál: Magyar középkori adattár. Magyarország világi archontológiája 1301-1457. Középkori magyar genealógia. MTA Történettudományi Intézete. [Bp.] 2001. [CD-ROM].

Entz = Entz Géza: Erdély építészete a 14-16. században. Kolozsvár 1996.

ErdKLt $=$ Beke Antal: Az erdélyi káptalan levéltára Gyulafehérvárt. Bp. 1889-1895. (Klny a TTár megfelelő évfolyamaiból).
ErdKJkv = Az erdélyi káptalan jegyzőkönyvei 1222-1599. Mutatókkal és jegyzetekkel regesztákban közzéteszi Bogdándi Zsolt, Gálfi Emőke. Kolozsvár 2006. (Erdélyi Történelmi Adatok VIII/1.).

Györffy = Györffy György: Az Árpád-kori Magyarország történeti földrajza. I-IV. Bp. 1987-1998.

Hanvay $=$ Az Abaffy család levéltára 1247-1515. A Dancs család levéltára 1232-1525. A Hanvay család levéltára 1216-1525. Ila B. kézirata alapján sajtó alá rendezte és szerkesztette Borsa Iván. Bp. 1993. (A Magyar Országos Levéltár Kiadványai II: Forráskiadványok 23.).

HOkm $=$ Codex diplomaticus patrius [Hungaricus]. Hazai okmánytár. Kiad. Nagy Imre, Páur Iván, Ráth Károly, Stummer/Ipolyi Arnold, Véghely Dezső. I-VIII. Győr-Bp. 1876-1891.

HOkl = Hazai oklevéltár 1234-1536. Szerk. Nagy Imre, Deák Farkas, Nagy Gyula. Bp. 1879.

HunyadmÉvk = A Hunyadmegyei Történelmi és Régészeti Társulat Évkönyve. I-XXII. Bp.-Arad-Déva. $1882-1913$.

1/1880-1881. (Bp. 1882). 52-78: Sólyom Fekete Ferenc: A magyarság és az oláh incolatus Hunyadban.

5/1887-1888. (Bp. 1889). 74-137: Sólyom Fekete Ferenc: Egy ős magyar telep Hunyadmegyében. 
11/1900. (Déva 1900). 58-69: Wertner Mór: Hunyadmegye legrégibb tisztikara (A XV. század végéig).

12/1901: 137-139 (Déva 1901):

Wertner Mór: Márton hunyadmegyei főispán családja.

Iczkovits = Iczkovits Emma: Az erdélyi Fehér megye a középkorban. Bp. 1939. (Település- és népiségtörténeti értekezések 2.).

Iványi: Gyömrő = A római szent birodalmi család gyömrői levéltára (Archivum Gyömröense gentis comitum Teleki de Szék). Irta és összeállította dr. Iványi Béla. Szeged 1937.

Iványi: Bánffy = A Tomaj nemzetség és a Tomaj nemzetségbeli losonczi Bánffy család története. Írta Iványi Béla. I. kötet. Kezdetektől 1526-ig. Bp. 1941.

Jajcza = Jajcza (bánság, vár és város) története 1450-1527. Írta Thallóczy Lajos. Az oklevéltárat szerkesztette Horváth Sándor. Bp. 1915. (Monumenta Hungariae Historica. Diplomataria XL. Magyarország melléktartományainak oklevéltára. Codex diplomaticus partium regno Hungariae adnexarum 4.).

Kádár-Tagányi $=$ Tagányi Károly Kádár József - Réthy László, dr. - Pokoly József: Szolnok-Dobokavármegye monographiája. I-VII. Deésen 1901-1905.

Jakó-Manolescu 1987 = Jakó Zsigmond-Manolescu, Radu: A latin írás története. Bp. 1987.
Kálniczky: Várnagyok $=$ Kálniczky László: Várnagyok és várkapitányok a Hunyadiak korában. In: Tanulmányok a bölcsészettudományok köréből. (A XV. Országos Tudományos Diákköri Konferencián díjat nyert dolgozatok). Tudományos Diákköri Füzetek 11. (Eötvös Loránd Tudományegyetem Tudományos Diákköri Tanács). Bp. 1982. 65-164.

Karácsonyi: Nemzetségek $=$ Karácsonyi János: A magyar nemzetségek a XIV. század közepéig. Bp. $1995^{2}$.

KárOkl = Codex diplomaticus comitum Károlyi de Nagy-Károly. A nagykárolyi gróf Károlyi család oklevéltára. Szerk. Géresi Kálmán. I-V (1253-1707). Bp. 18811897.

$\mathrm{KmJkv}=\mathrm{A}$ kolozsmonostori konvent jegyzőkönyvei. I-II (1289-1556). Kivonatokban közzéteszi és a bevezető tanulmányt írta Jakó Zsigmond. Bp. 1990. (A Magyar Országos Levéltár Kiadványai II: Forráskiadványok 17.).

$\mathrm{KmLt}=$ Beke Antal: A kolosmonostori konvent levéltára. Bp. 1898. (Klny a TTár 1896-1898. évfolyamából).

Kubinyi: Szapolyaiak=Kubinyi András: A Szapolyaiak és familiárisaik (szervitoraik). In: Tanulmányok Szapolyai Jánosról és a kora újkori Erdélyről. Miskolc 2004. (Studia Miskolcensia).

LtKözl = Levéltári Közlemények. A Magyar Országos Levéltár folyóirata. I-. Bp. 1923-. 
1/1923. 98-125: Hajnal István: Kivonatok Hunyadi János kormányzói okleveleiből.

9/1931. 38-111: Fekete Nagy

Antal: A Petróczy levéltár középkori oklevelei (Második közlemény).

55/1984. 2. sz. 111-139: Jakó Zsigmond: A kolozsmonostori apátság hamis oklevelei.

Lukcsics = Lukcsics Pál: XV. századi pápák oklevelei. I-II. Bp. 19311938. (Olaszországi magyar oklevéltár).

Makkai: Okl $=$ Kiadatlan oklevelek Kolozsvár középkori történetéhez. Írta Makkai László. Kolozsvár 1947.

Mályusz: Erdélyi társadalom = Mályusz Elemér: Az erdélyi magyar társadalom a középkorban. Bp. 1988. (Társadalom- és müvelődéstörténeti tanulmányok 2.).

MonRustReb $=$ Monumenta rusticorum in Hungaria rebellium anno MDXIV. Maiorem partem collegit Antonius Fekete Nagy. Ediderunt Victor Kenéz et Ladislaus Solymosi atque in volumen redegit Geisa Érszegi. Bp. 1979. (Publicationes Archivi Nationalis Hungarici II. Fontes 12.).

Ortvay: Temes $=$ Ortvay Tivadar: Oklevelek Temesvármegye és Temesvár város történetéhez. Másolta és gyüjtötte Pesty Frigyes. Sajtó alá rendezte Ortvay Tivadar. I (1183-1430). Pozsony 1896 (Temesvármegye és Temesvár város története. 4. köt.).
Pataki: Hunedoara $=$ Pataki, Iosif: Domeniul Hunedoara la începutul secolului al XVI-lea. Studiu şi documente. Buc. 1973. (Biblioteca istorică XXXIX.).

PerényiLt $=$ A Perényi család levéltára 1222-1526. Közzéteszi Tringli István. Bp. 2008. (A Magyar Országos Levéltár kiadványai II: Forráskiadványok 44.).

Pesty: Krassó $=$ Krassó vármegye története. Írta Pesty Frigyes. Harmadik kötet (Oklevéltár). Bp. 1883.

Petrichevich $=$ A Petrichevich család történetének regesztái. Első rész. II. kötet. 1069-1942. Írta báró Petrichevich Horváth Emil. (A Mogorovich nemzetségbeli Petrichevich család története és oklevéltára). Pécs 1942.

Podmaniczky = A podmanini Podmaniczky-család oklevéltára. Közzétette, családtörténeti bevezetéssel és jegyzetekkel ellátta Lukinich Imre. I-II. Bp. 1937-1939.

RegArp = Regesta regum stirpis Arpadianae critico-diplomatica. Az Árpád-házi királyok okleveleinek kritikai jegyzéke. I/1-II/4. Ed. Emericus Szentpétery et Iván Borsa. Bp. 1923-1990. (A Magyar Országos Levéltár kiadványai II: Forráskiadványok 9, 13).

RegVar $=$ Az időrendbe szedett váradi tüzesvaspróba-lajstrom. Az 1550-iki kiadás hû másával együtt. Dr. Karácsonyi János és Dr. Borovszky Samu akadémiai 1. tagok közreműködésével kiadja a Váradi Káptalan. Regestrum 
Varadinense examinum ferri candentis ordine chronologico digestum, descripta effigie editionis a. 1550 illustratum sumptibusque Capituli Varadinensis Lat. rit. curis et laboribus Joannis Karácsonyi et Samuelis Borovszky Academiae Scientiarum Hungaricae membrorum editum. Bp. 1903.

RevArh = Revista Arhivelor. Seria a III-a. (1997-től a folyóirat címe: Revista de Arhivistică.) Editată de Asociația Arhiviştilor „David Prodan" Cluj-Napoca. I-. ClujNapoca 1995-.

2/1996. nr. 1-2. 155-159: Răduțiu, Aurel: DIR, veacul XIV, C, Transilvania, vol. II (1321-1330). Addenda.

4/1998. nr. 1-2. 103-105: Szabadi Péter - W. Kovács András: Întregiri la Monumenta rusticorum in Hungaria rebellium anno MDXIV.

Sargetia. Acta Musei Devensis. I-. Deva 1966-.

18-19/1984-1985. 181-194: Feneşan, Costin: Ohaba şi Ponor - două moşii româneşti din Țara Hațegului şi stăpânii lor în secolele XV-XVI.

35-36/2007-2008. 203-240: W. Kovács András: Administrația comitatului Hunedoara în evul mediu.

Simon: Szapolyai familiárisai $=\mathrm{Si}-$ mon Zsolt: Szapolyai János familiárisainak egy lajstroma 1531ből. In: Tanulmányok Szapolyai Jánosról és a kora újkori Erdély- ről. Miskolc 2004. (Studia Miskolcensia 5.). 231-243.

Szerbia = Thallóczy Lajos - Áldásy Antal: Magyarország melléktartományainak oklevéltára. II. kötet. A Magyarország és Szerbia közti összeköttetések oklevéltára (1198-1526). Bp. 1907.

Sz = Századok. A Magyar Történelmi Társulat közlönye. I-. Bp. 1867-.

21/1887. Pótfüzet 32-48. Sólyom Fekete Ferenc: Jelentés Hunyad vármegye közlevéltárairól, családi leveles ládáiról és elszórt okmánykincseiről.

SzOkl = Székely Oklevéltár. Szerk. Szabó Károly, Szádeczky Lajos, Barabás Samu. I-VIII. Kolozsvártt-Bp. 1872-1934.

TelOkl = Codex diplomaticus sacri Romani imperii comitum familiae Teleki de Szék. A római szent birodalmi gróf széki Teleki család oklevéltára. Szerk. Barabás Samu. I-II. Bp. 1895.

ThLt $=$ A torockószentgyörgyi Thorotzkay család levéltára. Ismerteti Jakó Zsigmond és Valentiny Antal. Kolozsvár 1944. (Erdélyi Nemzeti Múzeum Levéltára 1.).

TTár = Történelmi Tár. Évnegyedes folyóirat. Kiadja a Magyar Történelmi Társulat közvetítése mellett a Magyar Tudományos Akadémia Történelmi Bizottsága. Bp. 1878-1911.

12/1889. 555-587, 753-772; 13/1890. 130-154，360-366; 14/1891. 109-138; 15/1892. 
493-512, 635-650; 16/1893. 93-108, 291-306, 459-473, 617-630; 18/1895. 230-259, 409-432, 630-652; 19/1896. 45-62: Beke Antal: Az erdélyi káptalan levéltára Gyulafehérvárt.

12/1889. 523-554, 728-752; 13/1890. 102-129, 328-359: Szabó Károly: Az Erdélyi Múzeum eredeti okleveleinek kivonata.

19/1896. 483-504, 718-736; 20/1897. 339-360, 496-512, 733-748; 21/1898. 151-166, 343-356, 532-555, 653-669: Beke Antal: A kolosmonostori konvent levéltára.

20/1897. 439-486, 653-679; 21/1898. 105-133: Wertner Mór: Árpádkori megyei tisztviselők (I-III).

6/1905 (Új folyam). 42-61, 164-184: Wertner Mór: Újabb adalékok az Árpádkori megyei tisztviselők ismeretéhez (I-II).

7/1906 (Új folyam). 583-609; 8/1907 (Új folyam). 1-69, 161-198, 327-354: Wertner Mór: Adalékok a XIV. századbeli magyar világi archontologiához (I-IV. közlemény).

8/1907 (Új folyam). 80-120: Magyari Károly: Regesták Alsófehérvármegye levéltárából.

TudGyüjt = Tudományos Gyüjtemény. I-XXV. Pest 1817-1841.
7/1831. 25-44: Kenderesi Ferenc: Vajda Hunyadvár külső tekintetben és ennek történeti leírása az újabb időkig.

Turul = Turul. A Magyar Heraldikai és Genealógiai Társaság közlönye. I-LXIV. Bp. 1883-1950.

10/1892. 105-111: Décsényi Gyula: A somkereki Erdélyi család 1415. évi czímeres levele és nemzedékrendje.

82/2009. 1. sz. 1-12: Rüsz-Fogarasi Enikő: Kolozs vármegye szolgabírái a középkorban.

Hațeg = Izvoare privind evul mediu românesc. Țara Hațegului în secolul al XV-lea (1402-1473). Introducere, ediție îngrijită, note şi traduceri de Adrian Andrei Rusu, Ioan Aurel Pop, Ioan Drăgan. Cluj-Napoca 1989. (Testimonia).

$\mathrm{Ub}=$ Zimmermann, Franz - Werner, Carl - Müller, Georg - Auner, Michael - Gündisch, Gustav - Gündisch, Herta - Nussbächer, Gernot - Gündisch, Konrad G.: Urkundenbuch zur Geschichte der Deutschen in Siebenbürgen. I-VII(1191-1496). HermannstadtBukarest 1892-1991.

VerArch = Archiv des Vereins für siebenbürgische Landeskunde. Herausgegeben vom VereinsAusschuss. I-L. Hermannstadt 1845-1944.

29/1899. 236-311: Wertner Moritz: Siebenbürgens Komitatsbeamtenkörper bis zum Ende des vierzehnten Jahrhunderts. 
Veress: Acta et epistolae IV. $=$ Acta et epistolae relationum Transylvaniae Hungariaeque cum Moldavia et Valachia. Collegit et edidit Andreas Veress. Bp. 1914. (Fontes Rerum Transylvanicarum IV.).

Veress: GyulaOklt $=$ Gyula város oklevéltára (1313-1380). Szerkesztette Veress Endre. Bp. 1938.

WassLt = A Wass család cegei levéltára. Valentiny Antal oklevélkivonatait felhasználva bevezető tanulmányokkal és jegyzetekkel közzéteszi W. Kovács András. Kolozsvár 2006. (Erdélyi Nemzeti Múzeum Levéltára 3.).

Wenzel: Stibor $=$ Wenzel Gusztáv: Stibor vajda. Életrajzi tanulmány. Bp. 1874. (Értekezések a történeti tudományok köréből IV. 2.).

ZOkm = Nagy Imre - Nagy Iván - Véghely Dezső - Kammerer Ernő - Döry Ferenc - Lukcsics Pál - Áldásy Antal - Barabás Samu: A zichi és vásonkeői gróf Zichy-család idősb ágának okmánytára. Codex diplomaticvs domvs senioris comitvm Zichy de Zich et Vasonkeő. I-XII. PestBp. 1871-1931.

ZsOkl = Zsigmondkori oklevéltár. III/1-2 (1387-1410). Összeállította Mályusz Elemér. Bp. 1951-1958. III-VII (1411-1420). Mályusz Elemér kéziratát kiegészítette és szerkesztette Borsa Iván. Bp. 1993-2001. VIII-IX (1421-1422). Borsa Iván, C. Tóth Norbert. Bp. 2003-2004; X (1423). C. Tóth Norbert. Bp. 2007. (A Magyar Országos Levéltár kiadványai II:
Forráskiadványok 1, 3-4, 22, 25, 27, 32, 37, 39, 41, 43.).

Zsoldos: Archontológia $=$ Zsoldos Attila: Magyarország világi archontológiája 1000-1301. Bp. 2011. (MTA Történettudományi Intézete. História könyvtár. Kronológiák, adattárak 11.).

Zsoldos: IV. Béla és István = Zsoldos Attila: Családi ügy. IV. Béla és István ifjabb király viszálya az 1260as években. Bp. 2007. (História könyvtár. Monográfiák 24.). 


\section{EME}

\section{A FELHASZNÁLT KÉZIRATOS (LEVÉLTÁRI ÉS KÉZIRATTÁRI) FORRÁSOK ÖRZŐHELYEI ÉS AZOK RÖVIDÍTÉSEI}

E jegyzék a felhasznált levéltárak és kézirattári forrásgyűjtemények, azok őrzőhelyei és rövidítései felől nyújt tájékoztatást. A magyarországi középkori írásbeliség termékeként, annak keretei között létrejött levéltárakat és könyvtárakat a magyar szakirodalomban használt módon, történetileg kialakult magyar elnevezésük betürendjében sorolja fel, de jelenlegi hivatalos nevüket is megadja annak az államnak a nyelvén, melynek területén most őrzik. Ugyancsak a magyar elnevezésből formáltuk a rövidítésekként használt betűszavakat is.

Arhivele Naționale Cluj (Cluj-Napoca) lásd KolozsNLt

Arhivele Naționale Covasna (Sfântu Gheorghe) lásd KovásznaNLt

Arhivele Naționale Sibiu (Sibiu) lásd SzebenNLt

Bálintitt cs lt (az ENMLt-nak a KolozsNLt-ban őrzött anyagában)

Bánffy cs nemz. It (az ENMLt-nak a KolozsNLt-ban és a KvEkt-ban őrzött anyagában)

Barcsay cs lt (KolozsNLt)

Batthyaneum = Batthyaneum-könyvtár, Gyulafehérvár (Biblioteca documentară Batthyaneum, Alba Iulia)

Beszterce v lt (KolozsNLt)

Bethlen, bethleni, cs lt (DL)

Bethlen, iktári, cs lt (az ENMLt-nak a KolozsNLt-ban őrzött anyagában)

Biblioteca Centrală Universitară „Lucian Blaga”, Cluj-Napoca lásd KvEKt Biblioteca documentară Batthyaneum, Alba Iulia lásd Batthyaneum Bornemisza cs (kászoni br) lt (ENMLt)

Brassó v lt (BrassóNLt) 
BrassóNLt = A Nemzeti Levéltár Brassó Megyei Igazgatósága, Brassó (Direcția Județeană Braşov ale Arhivelor Naționale, Braşov)

Bukaresti Állami Lt (Direcția Arhivelor Naționale Istorice Centrale, Bucureşti), Erdélyi iratok gyüjteménye

Cornides-gyűjtemény = Cornides Dániel Diplomatarium című kéziratos forrásgyưjteménye. (Ennek eredeti kötetei az MTAKt Kézirattárában találhatók, az ezekből Kovachich Márton György részére készült válogatás köteteit viszont az OSZK Kézirattára őrzi FolLt 2220. sz. alatt.)

Családi fondtöredékek (MOL)

Dés v lt (KolozsNLt)

DF = Diplomatikai Fényképgyűjtemény (MOL)

DL = Diplomatikai Levéltár (MOL)

Dobó József (fejérvári) gyưjteménye

ENMLt = Erdélyi Nemzeti Múzeum Levéltára (a KolozsNLt és a KvEKt, valamint a KvAKt őrizetében)

ENMLt Törzsgyüjtemény = Erdélyi Nemzeti Múzeum Levéltárának Törzsgyűjteménye (a KolozsNLt és a KvEKt őrizetében)

Erdélyi fiscalis levéltár (DL)

Erdélyi káptalan hiteleshelyi lt (DL)

Erdélyi káptalan mlt (a Batthyaneum őrizetében)

Esterházy cs cseszneki lt (ENMLt)

Gyulafehérvári Káptalan Országos Levéltára (MOL)

Gyulay-Kuún cs lt (az ENMLt-nak a KolozsNLt-ben őrzött anyagában)

Hunyad megyei családok (korábban Sólyom Fekete Ferenc gyűjteménye; MOL)

Jósika cs hitb. It (az ENMLt-nak a KolozsNLt-ban őrzött anyagában)

Károlyi cs lt (DL)

Kemény cs csombordi lt (a KolozsNLt-ban)

Kemény: DiplApp = Kemény, Josephus: Diplomatarii Transsilvanici Appendix, kéziratos másolatgyűjtemény (Kemény József gyűjteményének a KvAKt-ban őrzött anyagában)

Kemény: DiplSuppl = Kemény, Josephus: Diplomatarii Transsilvanici Supplementum, kéziratos másolatgyưijtemény (Kemény József gyüjteményének a KvAKt-ban őrzött anyagában)

Kemény: DiplTr = Kemény, Josephus: Diplomatarium Transsilvanicum, kéziratos másolatgyűjtemény (Kemény József gyüjteményének a KvAKt-ban őrzött anyagában)

Kemény cs csombordi lt (KolozsNLt) 
Kemény cs malomfalvi lt (az ENMLt-nak a KolozsNLt-ban őrzött anyagában; Kemény Pál letéte)

Kemény József gyűjteménye (az ENMLt-nak a KolozsNLt-ban és a KvAKtban őrzött anyagában)

KolozsNLt = A Nemzeti Levéltár Kolozs Megyei Igazgatósága, Kolozsvár (Direcția Județeană Cluj ale Arhivelor Naționale, Cluj-Napoca)

Kolozsmonostori konvent hiteleshelyi lt (DL; MOL)

Kolozsmonostori konvent mlt (a Batthyaneum őrizetében)

Kolozsvár v lt (KolozsNLt)

K[olozsvári] Papp Miklós gyưjteménye (DL)

Kornis cs szentbenedeki lt (az ENMLt-nak a KolozsNLt-ban őrzött anyagában)

KovásznaNLt = A Nemzeti Levéltár Kovászna Megyei Igazgatósága, Sepsiszentgyörgy (Direcția Județeană Covasna ale Arhivelor Naționale, Sfântu Gheorghe)

KvAKt = Kolozsvári Akadémiai Könyvtár (Biblioteca Academiei Române, Filiala Cluj-Napoca)

KvEKt = Kolozsvári Egyetemi Könyvtár (Biblioteca Centrală Universitară „Lucian Blaga”, Cluj-Napoca)

Lázár (szárhegyi) cs meggyesfalvi lt (ENMLt)

Magyar Nemzeti Múzeum, Törzsanyag (DL)

Magyar Mezőgazdasági Múzeum (Bp.), oklevélgyűjtemény

Megyei iratok (MOL)

Mike Sándor gyüjteménye (az ENMLt-nak a KvAKt-ban és a KolozsNLtban őrzött anyagában)

MOL = Magyar Országos Levéltár, Bp.

MTA = Magyar Tudományos Akadémia, Bp.

MTAKt = Magyar Tudományos Akadémia Könyvtára, Bp.

Nagy Jenő csíkszentmártoni gyưjteménye (a KovásznaNLt őrizetében)

Nemes, hídvégi, cs lt (ENMLt)

Pozsonyi Területi Állami Levéltár (Štátny Ústredný Archív SR Bratislava)

Radák cs lt (DL)

Révay család központi levéltára (Pozsonyi Területi Állami Levéltár)

Sólyom Fekete Ferenc gyüjteménye lásd Hunyad megyei családok

Sombory cs lt (DL)

Štátny Ústredný Archív SR Bratislava lásd Pozsonyi Területi Állami Levéltár

Suky cs lt (az ENMLt-nak a KolozsNLt-ban őrzött anyagában)

SzNLt $=$ Szász Nemzeti és Szeben v lt (SzebenNLt) 
SzebenNLt = A Nemzeti Levéltár Szeben Megyei Igazgatósága, Nagyszeben (Direcția Județeană Sibiu ale Arhivelor Naționale, Sibiu)

Teleki cs marosvásárhelyi lt (DL)

Toldalagi cs lt (az ENMLt-nak a KolozsNLt-ban őrzött anyagában)

Török Bertalan gyüjteménye (az ENMLt-nak a KolozsNLt-ban őrzött anyagában)

Vay cs berkeszi lt (DL)

Wass cs lt (az ENMLt-nak a KolozsNLt-ban őrzött anyagában)

Wesselényi cs bp.-i lt (DL)

Wesselényi cs zsibói lt (az ENMLt-nak a KolozsNLt-ban őrzött anyagában)

Zimmermann: Urkundenbuch = Zimmermann, Franz: Urkundenbuch zur

Geschichte der Deutschen in Siebenbürgen (kéziratos másolatgyüjtemény a Szász Nemzeti és Szeben v lt-ban) 


\section{BELSŐSZOLNOK VÁRMEGYE}

Vö. VerArch 29/1899. 303-306 (Wertner M.); Kádár-Tagányi VII. 178-179, 204-206, 212-213, 218; Zsoldos: Archontológia 209-211.

[Gerendi] Miklós comes (Péter fia) ispán (1325)

1325. VIII. 2. (Bánffy cs nemz. lt, DF 260589. = CDTrans II. 529. sz.); 1325.

IX. 18-i adat is (DL 62683. = CDTrans II. 532. sz.); 1325. X. 4. (Dés v lt, DF 253308. = CDTrans II. 537. sz., kétes hitelű oklevél).

[almakeréki Apafi?] Gegus magister (1325) és István comes (1325) szolgabirák 1325. IX. 18. (DL 62683. = CDTrans II. 532. sz.); 1325. X. 4. (Dés v lt, DF 253308. = CDTrans II. 537. sz., kétes hitelü oklevél).

[Zsuki] Mihály magister (Albert fia) ispán (1329-1332)

1329. [VIII. 27. k.] (DL 30367. = CDTrans II. 662. sz.); 1332. VI. 8. (DL 30367. = CDTrans II. 753. sz.)

Myke comes szolgabíró (1329)

1329. [VIII. 27. k.] (DL 30367. = CDTrans II. 662. sz.)

[Torockói] István (Elleus fia) alispán (1349)

1349. IX. 17. (Dés v lt, DF 253311. = CDTrans II. 526. sz.)

[Járai] Gál magister (Pascha fia) ispán (1355)

1355. VI. 11. (Bánffy cs nemz. lt, DF 260633. = CDTrans III. 793. sz.)

[Besenyő?] Pál ispán (1368)

1368. VIII. 23. (DL 62724. = Ub II. 317-318. = DRH C. XIII. 541-542).

[Derencsényi] János magister (Pető fia) ispán (1370)

1370. VI. 5. (Wass cs lt, DF 252786. = WassLt 155. sz.). Egyidejúleg Bálványos vár várnagya (BSz, 1364-1371). 
[Szilkeréki] István (Márton fia) (1370) és [Tötöri] László (Myke fia) (1370) szolgabírák

1370. VI. 5. (Wass cs lt, DF 252786. = WassLt 155. sz.); 1370 (Kádár-Tagányi VII. 204).

Dengelegi István (1392, 1399) és Némai Mihály (Petó fia) (1392) szolgabírák

1392. V. 1. (DL 73798. = TelOkl I. 238. = ZsOkl I. 2496. sz.)

[Szavai] László (Márk fia) ispán (1392)

[Szilágytői] Miklós (Kozma fia) $(1392,1407)$ és István (Pető fia) (1392) szolgabirák 1392. VIII. 14. (DL 73799. = TelOkl I. 239-240. = ZsOkl I. 2597. sz.)

Andrásházi „Darabos” Mihály magister (István fia) ispán (1397-1400)

1397. XI. 4. (DL 73813. = TelOkl I. 261. = ZsOkl I. 5053. sz.); 1398. VI. 26. (DL 73821. = TelOkl I. 265. = ZsOkl I. 5382. sz.); [1399. k.] (DL 74438. $=$ TelOkl I. 271. = ZsOkl I. 6225. sz.); 1400. X. 6. (DL 73832. = TelOkl I. 273. = ZsOkl II/1. 533. sz.)

Szilágytői Lesták (Leusthasius) magister (1397-1398, 1400) és Szilkeréki János magister (Jakab fia) (1397-1398, 1400-1406) szolgabírák

1397. XI. 4. (DL 73813. = TelOkl I. 261. = ZsOkl I. 5053. sz.); 1398. V. 22. $($ DL 73820. $=$ TelOkl I. 264-265. = ZsOkl I. 5330. sz.); 1398. VI. 26. (DL 73821. = TelOkl I. 265. = ZsOkl I. 5382. sz.); 1398. [VII. 2. k.] (DL 74437. = TelOkl I. 268. = ZsOkl I. 5392. sz., ebben tévesen: Szilkeréki Jakab fia: Jakab); 1398. [VIII. 21.?] (DL 73822. = TelOkl I. 266. = ZsOkl I. 5446. sz.)

Mikeházi Antal magister (1399) és Dengelegi (d) István magister (1392, 1399) szolgabirák

1399. XII. 10. (DL 73828. = TelOkl I. 271. = ZsOkl I. 6194. sz.); [1399 k.] $($ DL 74438. $=$ TelOkl I. 271. = ZsOkl I. 6225. sz.)

Szilágytői Lesták (Leusthasius) (1397-1398, 1400) és Szilkeréki János (Jakab fia) (1397-1398, 1400-1406) szolgabirák

1400. IX. 1. (DL 73831. = TelOkl I. 272-273. = ZsOkl II/1. 471. sz.); 1400.

X. 6. (DL 73832. = TelOkl I. 273. = ZsOkl II/1. 533. sz.)

Galaci Miklós ispán (1405)

1405. II. 25. (DL 62766. = ZsOkl II/1. 3680. sz.)

Szilkeréki János (Jakab fia) (1397-1398, 1400-1406) és Jánoktelki/Jánoki Antal (Péter fia) $(1405-1406,1408)$ szolgabírák

1405. II. 25. (DL 62766. = ZsOkl II/1. 3680. sz.); 1406. VII. 28. (DL 62769). 
Szilágytői Miklós (Kozma fia) (1392, 1407) és Girolti Veres (Rufus) Miklós (1407) szolgabírák

1407. III. 2. (DL 73872. = TelOkl I. 317-318. = ZsOkl II/2. 5336. sz.)

Jánoktelki Antal (Péter fia) (1405-1406, 1408) és Szentiványi István (János fia) (1408) szolgabírák

1408. VII. 18. (DL 62777. = ZsOkl II/2. 6238. sz.)

Drági Jakab ispán (1431)

[Belső]szolnok vm. ispánja

1431. V. 7. (Kornis cs lt: DL 37294. = DF 257669). - Egyidejűleg Doboka vm. ispánja (1429-1431).

[szentmártoni] Medvés Antal alispán (1434-1435)

1434. X. 27. (DL 74057. = TelOkl I. 535); 1434. XII. 1. (DL 74057. = TelOkl I. 535-536); 1435. III. 23. (DL 74057. = TelOkl I. 536); 1435. V. 4. (DL 74057. = TelOkl I. 537-539).

Girolti Antal (1434-1435) és Szilágytôi János (1434-1435) szolgabirák

1434. X. 27. (DL 74057. = TelOkl I. 535); 1434. XII. 1. (DL 74057. = TelOkl I. 535-536); 1435. III. 23. (DL 74057. = TelOkl I. 536).

Girolti Antal (1434-1435) és Némai Gergely (1435) szolgabirák

1435. V. 4. (DL 74057. = TelOk1 I. 537-539).

tárkányi [Boda] Dénes ispán (1443)

Szentgyörgyi Miklós (1443) és Dengelegi Zsigmond (1443) szolgabirák

1443. I. 2. (Beszterce v 1t, DF 247260. = Berger: Regesten I. 111. sz., az adatot idézi Engel: Arch. I. 246).

Deáki Balázs (1449-1455) és Szilkeréki Jakab (1449) szolgabirák

[1449.] IV. 14. (KmJkv I. 682. sz.)

szentegyedi Székely István (1452) és Bádoki Balázs (1452-1455) alispánok

Deáki Balázs (1449-1455) és Szilkeréki András (1452) szolgabirák

1452. VIII. 9. (Bánffy cs nemz. 1t, DF 260971-260972). - Bádoki Balázs egyidejűleg Doboka vm. alispánja (1452). - Székely István egyidejüleg Doboka vm. alispánja/ispánja (1446-1452).

szamosfalvi Gyerőfi János (1455) és Bádoki Balázs (1452-1455) ispánok

Deáki Balázs (1449-1455) és Szilkeréki Péter (1455, 1468-1470) szolgabírák

1455. X. 8. (DL 74130). - Gyerőfi János egyidejűleg Doboka vm. ispánja (1455). 
Nagy Ambrus és Miskei Török Ferenc ispánok (1468)

Szilkeréki Péter (1455, 1468-1470) és Girolti Illés (1468) szolgabirák 1468. VIII. 17. (DL 62892. = Ub VI. 348).

Nagy Pál és Török Ambrus ispánok (1470)

Szilkeréki Péter (1455, 1468-1470) és szucsáki Ravasz Lukács (1470) szolgabirák 1470. VII. 4. (Kornis cs 1t, DF 257678, korábbi jelzete: DL 37301).

Galaci Lőrinc és borzafői Huszár Fülöp ispánok (1471)

Szilkeréki Miklós (1471, 1495) és Szilkeréki Mihály (1471) szolgabírák 1471. VII. 3. (Bánffy cs nemz. lt, DF 260794). - Huszár Fülöp egyidejüleg

Doboka vm. alispánja (1471).

makrai Kis Tamás ispán (1474)

Girolti Miklós (1474) és Deáki Mihály (1474) szolgabírák 1474. V. 25. (Bánffy cs nemz. lt, DF 260804).

szilvási Tót István ispán (1476)

Kodori András (1476, 1484-1485) és szentgyörgyi Porkoláb Sandrinus (1476) szolgabírák

1476. IV. 10. (DL 74202. = TelOkl II. 127-128).

Nagy Barnabás és Bot Miklós alispánok (1482)

szilkeréki Mórici Péter (1482) és szentiványi Keresztesi Antal (1482-1483) szolgabírák

1482. III. 27. (DL 62914).

Zolardus ispán (1483-1485)

1483. II. 19. (DL 62916); 1484. II. 4. (DL 62919); 1484. IV. 14. (DL 62920); 1485. III. 30. (DL 62921).

szentiványi Keresztesi Antal (1482-1483) és Szilkeréki Demeter (1483-1485) szolgabirák

1483. II. 19. (DL 62916).

Zorad ispán (1483-1485) és Nagy János alispán (1484)

Kodori András (1476, 1484-1485) és Szilkeréki Demeter (1483-1485) szolgabirák 1484. II. 4. (DL 62919); 1484. IV. 14. (DL 62920); 1485. III. 30. (DL 62921, ebben Nagy János alispán nem szerepel).

kidei Fegyveres György alispán (1485-1487)

1485. V. 18. (DL 62922-62923); 1487. I. 3. (DL 62926). 
Kodori András (1476, 1484-1485) és Szilkeréki Demeter (1483-1485) szolgabírák 1485. V. 18. (DL 62922-62923).

Girolti Márton (1487) és Mikeházi Bálint (1487) szolgabirák 1487. I. 3. (DL 62926).

Péterházi Péter szolgabíró (1488)

1488. IV. 4. (jelentés fogalmazványa 1488. IV. 2-i oklevél hátlapján, DL 30052).

Nagy Máté alispán (1495)

Szilkeréki Miklós (1471, 1495) és Almádi Mihály (1495) szolgabirák 1495. V. 27. (Bánffy cs nemz. lt, DF 260841-260842).

Horvát Kelemen és Palásti Péter ispánok (1509)

Némai Tamás (1509) és Mikeházi Imre (1509) szolgabírák 1509. II. 14. (DL 62984).

Szilvási Kristóf ispán (1515 e.) 1515 k. (DL 36607).

Belsőszolnok vármegye nemességének egyeteme (universitas nobilium conprovincialium comitatus Zolnok interioris)

sztrigyi Mányiki Simon alispán (1519)

Mikeházi Fülöp és Iklódi Márton szolgabirák (1519)

1519. XI. 9. (iktári Bethlen cs lt, DF 255102); 1519. X. 20. (VI. d. Sab.a. Galli conf., DL 28030, idézi Kádár-Tagányi VII. 206, hibás keltezéssel; az oklevél csak Mikeházi Fülöp szolgabírát említi).

Makrai Bertalan

1527. VI. 24. (Berger: Regesten I. 981-982. sz.)

Kozárvári László ispán (comes comitatus Zolnok) (1529-1536)

1529. VIII. 13. (Berger: Regesten I. 1169. sz.); 1536. VI. 29. u. (KvEKt, Bánffy cs nemz. lt, középkori oklevelek, 595. sz.)

Kendi Mihály ispán (1539)

1539. VI. 12. (Beszterce $\mathrm{v} l \mathrm{t}=$ Berger: Regesten I. 1413. sz. - Az oklevelet 2010-ben a Román Nemzeti Levéltár Kolozs Megyei Fiókjában őrzött besztercei lt-ban nem sikerült fellelni). 
EME 


\section{DOBOKA VÁRMEGYE}

Vö. TTár 1897. 466; 1905. 50; 1907. 4-5 (Wertner M.); VerArch 29/1899. 244-253 (Wertner M.); Kádár-Tagányi VII. 279-280, 295-298, 302-303, 307, 309-310; Györffy II. 41-94; Zsoldos: Archontológia 147-148.

Doboka (Dobuca; Csanád fia) [ispán] [1000 k.?]

(Scriptores rerum Hungaricarum tempore ducum regumque stirpis Arpadianae gestarum. Edendo operi praefuit Emericus Szentpétery. I. Budapestini 1937. 50.)

[Rátót nb.] Lesták ispán (Eustachius, comes de Dobuka) (1165-1166 k.) [1165-1166 k.] (Veszprémi Érseki és Főkáptalani Levéltár, DF 200001. = RegArp I/1-3. 106. sz., keltezésére lásd: LtKözl 46/1975. 1. sz. 66, Kubinyi A.)

Zakeus, curialis comes (1213)

[1213]. (CDTrans I. 45. és 46. sz. = RegVar p. 157, 6. [376.] sz. és p. 158, 7. [377.] sz.)

Vajda ispán (Voiouoda, comes de Doboka) (1214-1219)

1214. (CDTrans I. 67. sz. = RegVar p. 181-182, 78. [304.] sz.). Vö. [1219] (CDTrans I. 99. sz. = RegVar p. 230-231, 212. [44.] sz.)

[Kökényes-Radnót nb. Dobokai] Mikod ispán (Micud comes) (1265, 1274)

[1262-1268 k.] (1265 k.-re: comitatum suum tunc temporis de Dabaka ad manus nostras resignavit, DL 73627. = 1269: CDTrans I. 275. sz.)

[Miskolc nb.] Panyit ispán (Ponith, comes de Doboka) (1268)

1268. (CDTrans I. 273. sz. = RegArp II/1. 1884. sz.) 
[Kemény fia] Lőrinc ispán (1270-1272)

1270. VIII. 27. (DL 40154. = RegArp II/1. 1959. sz.); 1271. III. 23. (uo. II/1. 2083. sz.); 1271. IX. 20. (uo. II/1. 2109. sz.); 1272. III. 18. (DL 781. = uo. II/1. 2174. sz.); 1272. V. 23. (CDTrans I. 316. sz. = RegArp II/1. 2190. sz.); 1272. VI. 17. (RegArp II/1. 2213. sz.); 1272. VI. 25. (uo. II/2. 2216. sz.) - Egyidejűleg szörényi bán (1270-1272).

[korógyi Keled fia] Fülöp ispán (1272)

1272. VIII. 3. (DL 62395. = RegArp II/1. 2224. sz.); 1272. (DL 825. = RegArp II/1. 2225. sz.). - Egyidejúleg királyi pohárnokmester (1270-1272).

Pál ispán (1273)

1273. $($ DL 840. $=$ RegArp II/2-3. 2406. sz. = ÁÚO IX. 27-29). - Egyidejüleg szörényi bán (1272-1275) és valkói ispán (1273-1275).

[Drugh fia: Karászi] Sándor bán, ispán (1274)

1274. VIII. 27. (DL 41578. = CDTrans I. 331). - Egyidejúleg szebeni ispán (1274).

[Kökényes-Radnót nb. Dobokai] Mikod (Mykud) bán, ispán (1265, 1274)

[1274?] XI. 1. (banus, comes de Doboka, Cornides, D.: Diplomatarium II. 147, MTAKt $=$ CDTrans I. 332. sz., vö. DL 73627. = CDTrans I. 275. sz.). - A királyi tanácsban bekövetkezett gyakori változások alapján az 1276. évi keltezés is lehetséges.

[Drugh fia: Karászi] Sándor bán, ispán (1274)

1274. [XII. 25-30.] (Szlovák Nemzeti Levéltár, Leleszi konvent hiteleshelyi lt, Acta anni 24A, DF 221076. = RegArp II/2-3. 2566. sz.). - Egyidejúleg szebeni ispán (1274).

[Keresztesi] Mihály (Kaza fia) (1305) és [Tötöri?] Deme (Miklós testvére) (1305) szolgabirák (iudices provincie)

[1305. XI. 25.] (ENMLt, Törzsgyüjtemény, DF 253653. = CDTrans II. 47. sz.)

[Gyulai] Lorand (Artolf fia) (1315), [Gyulai] Gula/Jula comes (Artolf) (1315) és [Mórici] János (Márton fia) szolgabirák

1315. XI. 13. (Wass cs lt, DF 252753, CDTrans II. 256. sz. = WassLt 13. sz.). - Gula/Jula comes (Artolph/Ortalph fia) [1315. X. 16. e.]; 1315. XI.

8. (Bánffy cs nemz. lt, DF 260925. = CDTrans II. 252-253. sz.)

[Dobokai] Miklós (Mikod/Mykud bán fia) ispán (1317)

1317. V. 10. (DL 30363. = CDTrans II. 272. sz.) 
[Mórici] János (Márton fia) comes ispán (1321-1334)

1321. XI. 4. (DL 27829. = CDTrans II. 410. sz.); [1326.] III. 30. (Wass cs 1t, DF 252700. = WassLt 18. sz.); 1326. IV. 25. (Wass cs lt, DF 252700. = WassLt 19. sz.); 1326. V. 3. (Wass cs 1t, DF $252700=$ WassLt 20. sz.); [1331. k.] VI. 15. (Wass cs lt, DF 252700. = WassLt 26. sz.); [1331. IX. 10. e.] (DL 40604. = CDTrans II. 718. sz.); [1331. IX. 10.] (DL 40604. = CDTrans II. 719. sz.); 1332. VI. 8. (DL 30367. = CDTrans II. 753. sz.); 1332. XII. 21. (ENMLt Törzsgyüjtemény, DF 253643. = CDTrans II. 765. sz.); 1333. VII. 26. (Bánffy cs nemz. 1t, DF 260599. = CDTrans II. 781. sz.); 1333. VIII. 29. (Bánffy cs nemz. lt, DF 260599. = CDTrans II. 783. sz.); 1334. I. 17. (Wass cs lt, DF 252738. = WassLt 30. sz.) - Mórici János Doboka vm. szolgabírája (1315).

[Lónai] Caplon/Coplon (1331) és Csép (Cheph d) János (1331) szolgabirák

[1331 k.] VI. 15. (Wass cs 1t, DF 252737. = WassLt 26. sz.); [1331. IX. 10. e.] $($ DL 40604. = CDTrans II. 718. sz.); [1331. IX. 10.] (DL 40604. = CDTrans II. 719. sz.)

Bádoki Péter (1332-1341) és Bongárdi János (1332) szolgabirák

1332. XII. 21. (ENMLt Törzsgyüjtemény DF 253643. = CDTrans II. 765. sz.)

Bádoki Péter (1332-1341) és Cseh (Cheh d) János (1334) szolgabirák 1334. I. 17. (Wass cs lt, DF 252738. = WassLt 30. sz.)

[Méhesi?] Miklós comes (Gyerö fia) ispán (1341)

Bádoki Péter (1332-1341) és [Boncnyíresi] János (Domokos fia) (1341) szolgabirák 1341. VI. 18. (Wass cs 1t, DF 252746. = WassLt 63. sz.)

[somkeréki Erdélyi] László magister (Geleth fia) ispán (1350)

Benedek (Lőrinc fia) (1350) és [Galaci] János (Demeter fia) (1350, 1361-1362) szolgabírák

1350. II. 16. (Wass cs lt, DF 252762. = WassLt 93. sz.)

[cegei] Wass (d) Miklós magister ispán (1361)

1361. XII. 14. (DL 73688).

[Galaci?] János (Demeter fia) (1350-1361) és [Kidei] János (Inok fia) (1361-1364) szolgabírák

1361. XII. 14. (DL 73688); 1362. XII. [8-13. e.] (DL 29069. = DRH C. XII. 114-117. = Makkai: Okl 7-8, 1366. XII. 13-i hibás keltezéssel).

[Derencsényi] Miklós magister (Pető fia) ispán (1364-1372)

1364. V. 7. (DL 73704. = TelOkl I. 131-132); 1364. VIII. 13. (DL 73707. = TelOkl I. 135-136); 1367. VI. 29. (Wass cs lt, DF 252778. = WassLt 146. sz.); 1369. VI. 26. (Wass cs lt, DF 252783. = WassLt 152. sz.); 1371. XI. 
18. (Wass cs lt, DF 252785. = WassLt 156. sz.); 1372. III. 9. (Wass cs lt, DF 252791. = WassLt 158. sz.). - Egyidejüleg Léta (1364, KL) és Bálványos vár (BSz, 1364-1371) várnagya.

[Kidei] János (Inok fia) (1361-1364) és Lónai Demeter (1364-1367) szolgabírák 1364. V. 7. (DL 73704. = TelOkl I. 131-132); 1364. VIII. 20. (DL 73707. = TelOkl I. 135-136. = DRH C. XII. 318-319).

Lónai Demeter comes (1364-1367) és [Szentegyedi] Mihály (Jakab fia) (1367-1372) szolgabírák

1367. VI. 29. (Wass cs 1t, DF 252778. = WassLt 146. sz.)

Szentegyedi Mihály magister (Jakab fia) (1367-1372) és Kendi Tamás (Raphael fia) (1369-1372) szolgabírák

1369. VI. 26. (Wass cs lt, DF 252783. = WassLt 152. sz.); 1371. XI. 18. (Wass cs lt, DF 252785. = WassLt 156. sz.); 1372. III. 9. (Wass cs lt, DF 252791. = WassLt 158. sz.); 1372. IV. 6. (Wass cs lt, DF 252792. = WassLt 159. sz.)

[Aranyi] István magister ispán (1378-1379)

1378. VI. 29. (Wass cs 1t, DF 252829. = WassLt 171. sz.); 1379. VIII. 16. (Wass cs lt, DF 252831. = WassLt 173. sz.); 1379. IX. 27. (Wass cs lt, DF 252840. = WassLt 174. sz.). - Bálványos vár (BSz) várnagya (1377).

Macskási Darabos Mihály (1378) és Bongárdi Mihály (1378) szolgabírák 1378. VI. 29. (Wass cs 1t, DF 252829. = WassLt 171. sz.)

Fürményesi Mihály (1379-1380) és Kidei (de Kege) Péter (1379) szolgabírák

1379. VIII. 16.; 1379. IX. 27.; 1379. XI. 28. (Wass cs lt, DF 252831, 252840, 252832. $=$ WassLt 173-175. sz.)

Fürményesi Mihály (1379-1380) és Zsombori Pál (Petô fia) (1380) szolgabírák 1380. I. 24. (Wass cs lt, DF 252833. és 252853. = WassLt 176. sz.)

Miklós magister (István fia) ispán (1384)

1384. VIII. 16. (Wass cs lt, DF 252839. = WassLt 190. sz.)

Olnoki Barnabás (1384) és Márkházi [=Frátai] Péter (Gál fia) (1384, [1384-1392?]) szolgabirák

1384. VIII. 16. (Wass cs 1t, DF 252839. = WassLt 190. sz.). - Márkházi [=Frátai] Péter Kolozs vm. szolgabírája (1398, 1403-1407). 
Szentmiklósi Jakab (1390-1397, 1406) és Macskási János (Márton fia) (1390) szolgabírák

1390. XII. 20. (Wass cs 1t, DF 252806. és DF 252796. = WassLt 205-206.

sz.)

Frátai [=Márkházi] Péter (Gál fia) (1384, [1384-1392?]) és Kendi Gergely ([13841392?] 1392-1397) szolgabírák

1408. X. 24. (DL 73898. = ZsOkl II/2. 6386. sz.). - Az 1408. X. 24-én kelt alvajdai oklevél Frátai Péter és Kendi Gergely dobokai szolgabírák okleveléről tesz említést. Márkházi/Frátai Péter dobokai szolgabíróságáról egyelőre csak 1384-ből van adat, társa, Kendi Gergely dobokai szolgabíróságáról pedig 1392-1397 közöttről. Kettejük egyidejű hivatalviselésére valószínúleg valamikor 1384 és 1392 között kerülhetett sor.

Göci Mihály magister ispán (1392)

1392. X. 22. (Wass cs lt, DF 252801. = WassLt 216. sz.)

Kendi Gergely ([1384-1392?], 1392-1397) és Szentmiklósi Jakab (1390-1397, 1406) szolgabírák

1392. X. 22. (Wass cs lt, DF 252801. = WassLt 216. sz.); 1393. X. (Wass cs lt, DF 252804. = WassLt 219. sz.); 1394. X. 20. (Wass cs 1t, DF 252808. = WassLt 223. sz.); 1397. V. 29. (DL 73811. = TelOk1 I. 259-260).

Drági László magister (Péter fia) ispán (1397-1400, 1406)

[1396. V. 28. u.] (DL 62759. = Wenzel: Stibor 92); 1397. X. 23. (DL 62758. = ZsOkl I. 5031. sz.); 1398. VI. 18. (DL 62759. = Ub III. 223-224. = ZsOkl I. 5376. sz. és 5164, hibásan I. 22-re keltezve); 1398. X. 8. (Wass cs lt, DF 252812. = WassLt 229. sz.); 1398. X. 22. (DL 73823; Wass cs lt, DF 252815. = WassLt 232. sz.); 1399. VII. 15. (DL 73826. = TelOkl I. 270); 1400. X. 19. (DL 73834. = TelOkl I. 273-274); 1400. X. 20. (DL 73835. = TelOkl I. 274).

Olnoki Pál (1397-1401, 1414) és Szentegyedi András (Mihály fia) (1397-1401, 1414, 1416-1420, 1423) szolgabirák

[1396. V. 28. u.] (DL 62759. = Wenzel: Stibor 92); 1397. X. 23. (DL 62758. = ZsOkl I. 5031. sz.); 1398. VI. 18. (DL 62759. = Ub III. 223-224. = ZsOkl I. 5376. sz. és 5164, hibásan I. 22-re keltezve); 1398. X. 8. (Wass cs 1t, DF 252812. = WassLt 229. sz.); 1398. X. 22. (DL 73823; Wass cs lt, DF 252815. = WassLt 232. sz.); 1399. VII. 15. (DL 73826. = TelOkl I. 270); 1400. X. 19. (DL 73834. = TelOkl I. 273-274); 1400. X. 20. (DL 73835. = TelOkl I. 274); 1401. I. 11. (DL 73838. = TelOkl I. 277-278); 1401. XI. 29. $($ DL 73844. $=$ TelOkl I. 281-282; DL 73843. = TelOkl I. 282-283). 
Dobokai János ispán (1404)

[1404.] XII. 29. (DL 74451. = ZsOkl. II/1. 3567. sz.)

Drági László magister (Péter fia) ispán (1397-1400, 1406)

1406. IX. 28. (DL 28133. = ZsOk1 II/1. 5021. sz.)

Bádoki János (1406-1407) és Szentmiklósi Jakab (1390-1397, 1406) szolgabirák 1406. IX. 28. (DL 28133. = ZsOkl II/1. 5021. sz.)

Bádoki László [!] (1407) és devecseri Fenesi László (1407) szolgabírák 1407. IV. 5. (Bánffy cs nemz. lt, DF 260940. = ZsOkl II/2. 5414. sz.)

Bádoki János (1406-1407) és Szentmiklósi Ferenc (1407) szolgabírák 1407. V. 31. (Wass cs lt, DF 252856. = WassLt 276. sz.)

marói Székely Péter alispán (1414)

1414. III. 27. (Wass cs 1t, DF 252872. = WassLt 319. sz.); 1414. VII. 31. (Wass cs lt, DF 252865. = WassLt 321. sz.); 1414. VIII. 28. (DL 73942. = ZsOkl IV. 2398. sz.)

Szentegyedi András (Mihály fia) (1397-1401, 1414, 1416-1420, 1423) és Olnoki Pál (1397-1401, 1414) szolgabírák 1414. III. 27. (Wass cs 1t, DF 252872. = WassLt 319. sz.)

Olnoki Pál (1397-1401, 1414) és Nyíresi István (1414-1415, 1426-1430) szolgabírák

1414. VII. 31. (Wass cs lt, DF 252865. = WassLt 321. sZ.); 1414. VIII. 28. (DL 73942. = ZsOkl IV. 2398. sz.)

[mikói] Kegye (Kege d) Miklós alispán (1415-1416, 1426-1428)

Nyíresi István (1414-1415, 1426-1430) és tóki Kis (vagy Konc) Mihály (1415) szolgabirák

1415. VII. 16. (DL 73953. = TelOkl I. 417).

Jánosdi Domokos alispán (1415)

Nyíresi István (1414-1415, 1426-1430) és tóki Kis Mihály (1415) szolgabírák 1415. VII. 30. (DL 73953. = TelOkl I. 417-418).

mikói (de Mico) Kegye (Kege d) Miklós alispán (1415-1416, 1426-1428)

1415. VIII. 20.; 1415. X. 8.; 1415. XII. 17.; 1415. XII. 31.; 1416. I. 14.; 1416. III. 10.; 1416. III. 24.; 1416. IV. 7. (DL 73953. = TelOkl I. 418-421, 416-423). 
Nyíresi István (1414-1415, 1426-1430) és tôki Kis Mihály (1415) szolgabírák

1415. VIII. 20.; 1415. X. 8.; 1415. XII. 17.; 1415. XII. 31. (DL 73953. = TelOkl I. 418-420).

sólyomkői Ördög (d) Miklós (1416-1419) és Szentegyedi András (Mihály fia)

(1397-1401, 1414, 1416-1420, 1423) szolgabírák

1416. I. 14.; 1416. III. 10.; 1416. III. 24.; 1416. IV. 7. (DL 73953. = TelOkl I. 420-421, 416-423); 1419. I. 3. (Kemény József gyüjt., DF 253486. = ZsOkl VII. 12. sz.). - Szentegyedi András (Mihály fia) 1418. IV. 2-án is szolgabíró (Wass cs lt, DF 253096. és 255388. = WassLt 353. sz.)

Tamásfalvi Tamás (Gergely fia) ispán (1419-1420)

1419. VII. 4. (DL 73976. = ZsOkl VII. 743. sz.); 1420. II. 27. (Wass cs lt, DF 252917. = WassLt 358. sz.); 1420. VI. 18. (Wass cs lt, DF 253046. = ZsOkl VII. 1855. sz. = WassLt 361. sz.)

sólyomkői Ördög Miklós (1416-1419) és Szentegyedi András (Mihály fia) (13971401, 1414, 1416-1420, 1423) szolgabírák

1419. VII. 4. (DL 73976. = ZsOkl VII. 743. sz.)

Szentegyedi András (Mihály fia) (1397-1401, 1414, 1416-1420, 1423) és Kidei András (1420) szolgabirák

1420. II. 27. (Wass cs 1t, DF 252917. = WassLt 358. sz.); 1420. VI. 18. (Wass cs lt, DF 253046. = ZsOkl VII. 1855. sz. = WassLt 361. sz.)

Drági Ferenc ispán [1421 e.?]

Egykori ispánként későn, 1456-ban említik (KmJkv II. 1251. sz.), de hivatalviselése az 1420 körüli évekre tehető (1416: TelOkl I. 424-425; leánygyermekei 1417-ben hajadonok, ZsOkl VI. 995. sz.; utolsó ismert említése 1421-ből való: ZsOkl VIII. 1148. sz.). 1408-ban Kolozs vm. ispánja és Léta várnagya (TelOkl I. 342).

Györgyfalvi Imre ispán (1423-1425)

1423. VI. 15. (DL 74001. = ZsOkl X. 801. sz.); alispán: 1425. VII. 30. (DL 27454, idézi Engel: Arch. I. 247).

Szentegyedi András (Mihály fia) (1397-1401, 1414, 1416-1420, 1423) és Olnoki István (Barnabás fia) (1423-1429) szolgabírák

1423. VI. 15. (DL 74001. = ZsOkl X. 801. sz.)

Olnoki István (Barnabás fia) (1423-1429) és Nyíresi István (1414-1415, 14261430) szolgabirák

1426. IV. 2. (DL 74014). 
[mikói] Kegye (Kege) Miklós alispán (1415-1416, 1426-1428)

1426. V. 14. (Wass cs lt, DF 252928. = WassLt 373. sz.); 1426. X. 8. (DL 74022); 1426. XII. 3. (DL 28193); 1427. XII. 30. (Wass cs 1t, DF 252934. $=$ WassLt 382. sz.); 1428. XI. 2. (Wass cs 1t, DF 252933. = uo. 388. sz.)

Olnoki István (Barnabás fia) (1423-1429) és Nyíresi István (1414-1415, 14261430) szolgabirák

1426. V. 14. (Wass cs lt, DF 252928. = WassLt 373. sz.); 1426. X. 8. (DL 74022); 1426. XII. 3. (DL 28193); 1427. III. 25. (Wass cs 1t, DF 252929. = WassLt 378. sz.); 1427. XI 18. (DL 74433); 1427. XII. 30. (Wass cs lt, DF 252934. = WassLt 382. sz.); 1428. IX. 8. (DL 43769); 1428. XI. 2. (Wass cs 1t, DF 252933. = WassLt 388. sz.)

Drági Jakab ispán (1429-1431)

1429. I. 11. (Wass cs lt, DF 253051. = WassLt 390. sz.); 1430. III. 7. (Wass cs lt, DF 252939. = WassLt 400. sz.); 1431. V. 7. (Kornis cs lt, DL 37295. = DF 257669), ekkor [Belső]szolnok vm. ispánja is.

Olnoki István (Barnabás fia) (1423-1429) és Nyirresi István (1414-1415, 14261430) szolgabírák

1429. I. 11. (Wass cs 1t, DF 253051. = WassLt 390. sz.)

Nyíresi István (1414-1415, 1426-1430) és csomafáji Tót Péter (1429-1430) szolgabirák

1429. XI. 15. (Wass cs 1t, DF 252936. = WassLt 396. sz.)

[feldevecseri] Devecseri Mihály (Miklós fia) alispán (1429-1430)

1429. XII. 13. (Wass cs lt, DF 253011. és 252938. = WassLt 397-398. sz.); 1430. III. 7. (Wass cs lt, DF 252939. = WassLt 400. sz.). - Devecseri Mihály utóbb Doboka vm. szolgabírája (1431-1436).

Nyiresi István (1414-1415, 1426-1430) és csomafáji Tót Péter (1429-1430) szolgabirák

1429. XII. 13. (Wass cs lt, DF 253011. és 252938. = WassLt 397-398. sz.); 1430. I. 3. (DL 74045); 1430. III. 7. (Wass cs 1t, DF 252939. = WassLt 400. sz.); 1430. V. 2. (Wass cs 1t, DF 252940. = WassLt 404. sz.); 1430. VII. 18. (Wass cs 1t, DF 252941. = WassLt 407. sz.)

szentmártoni Medvés Antal alispán (1431-1434)

1431. XI. 6. (Wass cs 1t, DF 252948. = WassLt 423. sz.); 1434. VI. 21. (kolozsmonostori konv. hiteleshelyi lt = DL 27293).

[feldevecseri] Devecseri Mihály (Miklós fia) (1431-1436) és Mikei (Mykey) Péter (1431) szolgabirák

1431. XI. 6. (Wass cs lt, DF 252948. = WassLt 423. sz.); Devecseri Mihály 1434. VI. 21-én is (DL 27293). 


\section{Indali Pál alispán (1435)}

1435. IX. 13. (DL 74062). - Indali Pál Kolozs vm. alispánja (1434-1435).

[feldevecseri] Devecseri Mihály (Miklós fia) (1431-1436) és Bádoki László (14351436) szolgabírák

1435. IX. 13. (DL 74062); 1436. IV. 10. (DL 74065).

Kidei István (1439) és devecseri Fenesi László (1439) szolgabírák

1439. V. 19. (DL 74071).

Benedek (1443) és Gergely (1443) ispánok

[gyekei?] Sztrigyi Györoy (1443-1446) és Fodorházi András (1443-1445) szolgabirák

1443. VI. 18. (ENMLt Törzsgyüjtemény, DF 253707).

szilágyi Nagy Jakab alispán (1444)

1444. I. 28. (Wass cs 1t, DF 252952. = WassLt 431. sz.)

[gyekei?] Sztrigyi Györoy (1443-1446) és Fodorházi András (1443-1445) szolgabírák

1444. I. 28. (Wass cs lt, DF 252952. = WassLt 431. sz.); 1444. III. 3. (Wass cs lt, DF 252953. = 432. sz.); 1444. VII. (TTár 1907. 93. = Petrichevich 355, 1866. sz.); 1444. VIII. 4. (Wass cs lt, DF 252956. = WassLt 434. sz.)

Bádoki László (1444) ispán

1444. XII. 15. (Wass cs 1t, DF 252955. = WassLt 435. sz.). - Az oklevélben tévesen Kolozs megyei ispánként szerepel. A hivatkozott oklevél valójában Doboka vm. hatóságának a kiadványa, mert Bonchidán kelt és mert a benne említett két szolgabíró - Sztrigyi György és Fodorházi András - korábban is Doboka vm. szolgabírájaként szerepelt. Bádoki László azonban 1445-ben már valóban Kolozs vm. ispánja (Suky cs 1t, DF 255297, vö. Engel: Arch. I. 250).

[gyekei?] Sztrigyi György (1443-1446) és Fodorházi András (1443-1445) szolgabírák

1444. XII. 15. (Wass cs 1t, DF 252955. = WassLt 435. sz.; az oklevélben elírás, hogy Kolozs vm. kiadványa lenne); 1445. IX. 21. (Wass cs 1t, DF 253065. = WassLt 436. sz.)

Szomordoki Domokos (1446-1448) és szentegyedi Székely István (14461452) alispánok

1446. IX. 13. (Bánffy cs nemz. lt, DF 260962); 1448. IV. 30. (Wass cs lt, DF 252959. = WassLt 438. sz.) 
[gyekei?] Sztrigyi György (1443-1446) és [kidei] Tóki Gergely (1446-1449) szolgabírák

1446. IX. 13. (Bánffy cs nemz. lt, DF 260962).

[kidei] Tóki Gergely (1446-1449) és Nyíresi Lukács (1448) szolgabírák 1448. IV. 30. (Wass cs lt, DF 252959. = WassLt 438. sz.)

Bádoki Antal (1448) és Szomordoki Domokos ispánok (1446-1448), szentegyedi Székely István alispán [!] (1446-1452)

[kidei] Tóki Gergely (1446-1449) és Nyíresi Lukács (1448) szolgabírák 1448. VIII. 13. (Wass cs lt, DF 252957. = WassLt 439. sz.)

szentegyedi Székely István ispán [!] (1446-1452)

[kidei] Tóki Gergely (1446-1449) és feldevecseri Kis István (1449-1452) szolgabirák 1449. XII. 2. (Wass cs 1t, DF 252966. = WassLt 441. sz.)

szentegyedi Székely István (1446-1452) és Esztényi István (1450) [al]ispánok alispánokként: 1450. III. 15. (KvEKt Kézirattár, oklevélgyűjtemény, 178/9. sz.); ispánokként: 1450. VI. 16. (DL 62849).

feldevecseri Kis István (1449-1452) és kidei Récsei Gergely (1450-1452) szolgabirák

1450. III. 15. (KvEKt Kézirattár, 178/9. sz.); 1450. VI. 16. (DL 62849).

szentegyedi Székely István (1446-1452) és Szalmatercsi János alispánok (1451)

feldevecseri Kis István (1449-1452) és kidei Récsei Gergely (1450-1452) szolgabírák

1451. X. 5. (Wass cs lt, DF 252960. = WassLt 442. sz.). - Szalmatercsi János egyidejúleg Kolozs vm. alispánja (1450-1451).

szentegyedi Székely István (1446-1452) és gyerőmonostori Kabos Péter alispánok (1452)

feldevecseri Kis István (1449-1452) és kidei Récsei Gergely (1450-1452) szolgabírák

1452. II. 8. (DL 44619).

szentegyedi Székely István (1446-1452) és Bádoki Balázs alispánok (1452, 1456)

feldevecseri Kis István (1449-1452) és kidei Récsei Gergely (1450-1452) szolgabirák

1452. V. 23. (DL 74117). - Bádoki Balázs és Székely István egyidejúleg Belsőszolnok vm. alispánjai (1452). 
Szentmiklósi Károly László (1453) és Újbudai Bálint (1453) ispánok

Nyíresi Mihály (1453-1466) és szentegyedi [Székely?] István (András fia) (14531455) szolgabirák

1453. III. 13. (Wass cs lt, DF 252962. = WassLt 446. sz.); 1453. VI. 19. (Suky cs lt, DF 255240. = Petrichevich 356, 1871. sz.)

szamosfalvi [Gyerőfi, filius Gerew] János (1455) és Devecseri András deák

(litteratus) ispánok (1455)

Nyíresi Mihály (1453-1466) és Szentegyedi [Székely?] Istoán (András fia) (14531455) szolgabirák

1455. VII. 8. (DL 27311). - Gyerőfi János egyidejúleg Belsőszolnok vm. ispánja (1455).

[szentmiklósi] Károly István (1456-1457) és Bádoki Balázs $(1452,1456)$ ispánok

Nyíresi Mihály (1453-1466) és Göci György (1456-1462) szolgabirák 1456. VIII. 24. (DL 74136).

szentmiklósi Károly István (1456-1457) és Szentpáli Pál (1457) ispánok

Nyíresi Mihály (1453-1466) és Göci György (1456-1462) szolgabirák 1457. VII. 19. (DL 74139).

Iklódi Márton (1460, 1465) és patai Dezső Antal (1460) ispánok

1460. IX. 30. (WassLt 456. sz.). - Dezső Antal egyidejúleg Kolozs vm. ispánja (1460).

Nyíresi Mihály (1453-1466) és Göci György (1456-1462) szolgabirák

1460. IX. 30. (Wass cs lt, DF 252969. = WassLt 456. sz.). - Göci György 1462.

X. 6. e. is. (KmJkv I. 1658. sz.)

Varsányi Péter alispán (1464)

Nyíresi Mihály (1453-1466) és mányiki Erdős János (1464-1465) szolgabírák 1464. IX. 26. (DL 62880).

Iklódi Márton ispán (1460, 1465)

Nyíresi Mihály (1453-1466) és mányiki Erdős János (1464-1465) szolgabirák 1465. I. 30. (DL 62882).

Iklódi Márton (1460, 1465) és Iklódi István (1465) ispánok

Nyíresi Mihály (1453-1466) és mányiki [Sztrigyi] László (1465-1470) szolgabirák

1465. VI. 26. (Wass cs lt, DF 252970. = WassLt 461. sz.) 
Csomafáji György alispán (1466)

Nyíresi Mihály (1453-1466) és mányiki [Sztrigyi] László (1465-1470) szolgabirák 1466. IV. 29. (Bánffy cs nemz. It, DF 260784).

mányiki Sztrigyi László (1465-1470) szolgabiró

1466. IX. 18. (DL 27914, forrás: Kádár-Tagányi VII. 297).

Nagy Pál (1470, 1475, 1476) és Nagy Bertalan (1470) alispánok

mányiki [Sztrigyi] László (1465-1470) és Kidei Frank (1470-1473) szolgabírák

1470. V. 15. (Bánffy cs nemz. lt, DF 260995). - Kidei Frank: 1470. V. 15. (DL 73726).

Miskei Ambrus (1471), [kápolnai] Nagy Tamás (1471) és borzafői (de Borzafew) Huszár Fülöp alispánok (1471)

Kidei Frank (1470-1473) és Göci [Porkoláb?] Demeter (1471-1473, 1487) szolgabirák

1471. I. 8. (DL 27338). - Huszár Fülöp egyidejűleg Belsőszolnok vm. alispánja (1471).

kápolnai Nagy Tamás (1471) és kápolnai Nagy Fülöp (1471) alispánok

Kidei Frank (1470-1473) és Göci [Porkoláb?] Demeter (1471-1473, 1487) szolgabirák

1471. VII. 9. (Bánffy cs nemz. lt, DF 261014).

Körtvélyesi György ispán (1473)

Kidei Frank (1470-1473) és Göci [Porkoláb?] Demeter (1471-1473, 1487) szolgabirák

1473. VIII. 3. (Bánffy cs nemz. lt, DF 261019).

Oláh András ispán (1475)

szentegyedi Valkai János (1475-1479) és Csomafáji Gergely (1475-1484, 1487) szolgabirák

1475. III. 14. (iktári Bethlen cs lt, DF 255035).

Bádoki Mihály (1475-1476) és Nagy Bálint (1475) ispánok

szentegyedi Valkai János (1475-1479) és Csomafáji Gergely (1475-1484, 1487) szolgabirák

1475. V. 30. (DL 62904).

Nagy Pál (1470, 1475, 1476) és Bádoki Mihály (1475-1476) alispánok

szentegyedi Valkai János (1475-1479) és Csomafáji Gergely (1475-1484, 1487) szolgabirák

1475. XI. 21. (Bánffy cs nemz. lt, DF 260809). 
Ezbwody Bernát ispán (1476)

szentegyedi Valkai János (1475-1479) és Csomafáji László [!] (1476) szolgabirák

1476. I. 30. (Kornis cs 1t, DF 257681, korábbi jelzete: DL 37304). - Csoma-

fáji László neve minden bizonnyal elírás Csomafáji Gergely helyett.

Nagy Pál (1470, 1475, 1476) és Bádoki Mihály (1475-1476) alispánok

szentegyedi Valkai János (1475-1479) és Csomafáji Gergely (1475-1484, 1487) szolgabírák

1476. III. 5. (DL 28313).

zsombori [Nagy] Albert alispán (1479-1481, 1487)

1479. XII. 7. (DL 62912); 1480. I. 4. (Kemény cs malomfalvi lt, DF 280925. = TTár 1907. 99).

szentegyedi Valkai János (1475-1479) és Csomafáji Gergely (1475-1484, 1487) szolgabírák

1479. XII. 7. (DL 62912); 1480. I. 4. (Kemény cs malomfalvi lt, DF 280925);

Csomafáji Gergely: [1480-ra] ([1481?]. III. 28., KmJkv I. 2314. sz.)

Németi Albert magister, [Belső]szolnok vármegye nótáriusa (1479)

1479. XII. 7. (DL 62912).

zsombori Nagy Albert (1479-1481, 1487) és esztényi Kis Tamás alispánok (1481)

Csomafáji Gergely (1475-1484, 1487) és szentegyedi Székely Lörinc (1481-1484) szolgabirák

1481. III. 27. (DL 45874). Csomafáji Gergely szolgabíró 1484. II. 18-án is (1484. III. 1., DL 27546).

szentegyedi Székely Lőrinc alispán (1487)

1487. III. 20. (Bánffy cs nemz. lt, DF 261054); 1487. V. 29. (uo., DF 261058).

- Egy, a közlője által 1479. III. 18. utánra keltezett protokollumbejegyzés (KmJkv I. 2272. sz. = DL 29056) szentegyedi Székely Lőrinc alispán és Csomafáji László szolgabíró nevét említi. Székely Lőrinc alispán hivatalviseléséről csak 1487-ből, Csomafáji László szolgabíró hivatalviseléséről pedig 1476-ból van adat (1476. I. 30.: Kornis cs 1t, DF 257681 = DL 37304).

[tóki?] Szilkeréki András (1487) és zsombori Roth András (1487) szolgabirák 1487. III. 20. (Bánffy cs nemz. lt, DF 261054).

[esztényi] Marói Lốrinc (1487) és Zsombori Mátyás (1487) szolgabírák

1487. V. 29. (Bánffy cs nemz. lt, DF 261058). 
zsombori Nagy Albert alispán (1479-1481, 1487)

Csomafáji Gergely $(1475,1476-1481,1487)$ és Göci [Porkoláb?] Demeter (14711473, 1487) szolgabirák

1487. VI. 19. (Bánffy cs nemz. lt, DF 261048).

cegói Zalai (Zalay) László, megyei választott esküdt (1489)

1489. II. 26. (DL 27554); 1489. IV. 6. (DL 27553. és 36841).

Szakácsi [Nagy] György [deák] (1493-1494) és [mányiki] Sztrigyi István alispánok (1493)

göci Fenesi Mihály (1493-1494) és kidei Frank Gergely (1493) szolgabírák

1493. XII. 3. (Wass cs 1t, DF 252972. = WassLt 484. sz.)

Szakácsi [Nagy] György deák alispán (1493-1494)

göci Fenesi Mihály (1493-1494) és tóki Szilkeréki Lukács (1494) szolgabirák

1494. X. 14. (Wass cs 1t, DF 255337. = WassLt 486. sz.)

Újfalusi Lukács deák, a vm. itélőszékének jegyzöje (1494-1495)

1494. X. 14. (Wass cs lt, DF 255337. = WassLt 486. sz.); 1495. X. 1. (Wass cs

lt, DF 252983. = WassLt 488. sz.); 1495. XI. 17. (Wass cs lt, DF 252983.

$=$ WassLt 489. sz.)

csomafáji Kidei János alispán (1495-1496)

tóki Girolti Miklós $(1495,1505)$ és kisdevecseri Balai Mihály (1495-1496) szolgabirák

1495. XI. 17. (Wass cs lt, DF 252983. = WassLt 489. sz.); 1496. V. 10. (Bánffy cs nemz. lt, DF 261074).

[szentegyedi] Valkai Péter (1498, 1510, 1515-1516) szolgabiró 1498. VIII. 9. (Wass cs 1t, DF 252985. = WassLt 496. sz.)

[gyerőmonostori] Dobszai Antal és Gesztrágyi Albert ispánok (1505)

[tóki] Girolti Miklós $(1495,1505)$ és Göci Mátyás (1505) szolgabirák 1505. I. 21. (Kemény József gyüjt., DF 253538).

gyulai Valkai Márton és Zutori István deák alispánok (1510)

szentegyedi Valkai Péter (1498, 1510, 1515-1516) és kidei Egyed István (1510) szolgabirák

1510. I. 8. (Wass cs lt, DF 253023. = WassLt 557. sz.)

gyulai Valkai Márton és Sárdi Kis Antal alispánok (1510)

szentegyedi Valkai Péter (1498, 1510, 1515-1516) és kidei Ispán Mátyás (1510) szolgabirák

1510. IV. 9. (Wass cs 1t, DF 253024. = WassLt 558. sz.) 
gyulai Valkai Márton és kidei Ispán Máté (!) alispánok (1510)

szentegyedi Valkai Péter (1498, 1510, 1515-1516) és kidei Egyed István (1510) szolgabirák

[1510?. VI. 4. u.] (Wass cs lt, DF 255397. = WassLt 563. sz.)

János deák (litteratus), Doboka vm. jegyzője (1512)

1512. VII. 8. (DL 74340).

Szászzsombori Salatiel (1511-1515) szolgabíró

1511. XI. 23. (Wass cs lt, DF 255370. = WassLt 567. sz.); 1512. VI. 7. (Wass cs lt, DF 255373. = WassLt 572. sz.); 1512. VII. 8. (Wass cs lt, DF 253032. = WassLt 575. sz.); 1513. I. 28. (Wass cs lt, DF 255380. = WassLt 582. sz.)

Kendi Gál ispán (1513-1524)

1513 (DL 29621, idézi: Kádár-Tagányi VII. 280); 1513. IV. 5. (DL 99264. = KárOkl III. 88-89); 1513. X. 16. (Wass cs 1t, DF 255357. = WassLt 602. sz.); 1514. IV. 4. (Wass cs lt, DF 253028. = WassLt 609. sz.); 1516. I. 15. (Wass cs lt, DF 255359. = WassLt 613. sz.); 1516. II. 12. (Wass cs lt, DF 255385. = WassLt 617. sz.); 1524. X. 11. (Wass cs 1t, DF 253043. = WassLt 639. sz.); 1525. III. 21. (Beszterce v lt, DF 247759. = Berger: Regesten 816. sz.)

Szászzsombori Salatiel (1511-1515) és Macskási Damján (1513-1516) szolgabírák 1513. IV. 5. (DL 99264. = KárOkl III. 88-89).

Göci Porkoláb Mátyás alispán (1513)

1513. V. 29. e. (Wass cs lt, DF 255402. = WassLt 587. sz., 1513. VI. 2.)

Szászzsombori Salatiel $(1511-1515)$ és Göci Mátyás $(1505,1513)$ szolgabírák

1513. VI. 3. (Wass cs 1t, DF 255353. = WassLt 588. sz.)

Szászzsombori Salatiel (1511-1515) és Macskási Damján (1513-1516) szolgabírák

1514. IV. 4. (Wass cs lt, DF 253028. = WassLt 609. sz.); 1515. II. 27. (Wass cs lt, DF 255385. = WassLt 617. sz., 1516. II. 12.)

Macskási Damján (1513-1516) és szentegyedi Valkai Péter (1498, 1510, 1515-1516) szolgabirák

1516. I. 15. (Wass cs lt, DF 255359. = WassLt 613. sz.); 1516. II. 12. (Wass cs lt, DF 255385. = WassLt 617. sz., 1516. II. 12.)

Sebestyén, vm.-i nótárius (1516)

1516. II. 12. (Wass cs lt, DF 255385. = WassLt 617. sz.) 
csehi Móré Miklós (1524, 1525, 1528) és zsombori Roth (Rood) János (1524-1525,

1536-1540) szolgabírák

1524. X. 11. (Wass cs lt, DF 253043. = WassLt 639. sz.). - Zsombori Roth

(Rood) János említve még: [1525.] I. 24. (Wass cs lt, DF 255400. = Wass-

Lt 643. sz.)

[zsombori] Roth (Rood) János (1524-1525, 1536-1540) ${ }^{10}$ szolgabíró

Devecseri Fábián, Doboka vármegye jegyzője

1525. II. 22. (Wass cs lt, DF 255386. = WassLt 645. sz.)

zsombori Roth János (1524-1525, 1536-1540) és csehi Móré Miklós (1524, 1525,

1528) szolgabirák

1525. III. 21. (Beszterce v lt, DF 247759. = Berger: Regesten 816. sz.)

kisdevecseri Devecseri Fábián magister, vm.-i jegyző (1520-1525)

1520. V. 20. (Bánffy cs nemz. lt, DF 261121); [1525.] I. 24. (Wass cs lt, DF 255400. = WassLt 643. sz.); 1525. II. 14. (Wass cs 1t, DF 255400. = WassLt 644. sz.); 1525. II. 22. (Wass cs lt, DF 255386. = WassLt 645. sz.); 1525. V. 16. (DL 65482).

csomafáji Baksa (Boxa) János (1528) és Csomafáji István (1528), alispánok

csehi Móré Miklós (1524, 1525, 1528) és szentegyedi Valkai István (1528) szolgabírák

1528. II. 20. (in oppido Bonczyda, f. V. p. Valentini mart., MTAKt, K 326. doboz, no. 668).

Gyulai János (1530-1540) és Diósi (de Diogh) Ferenc (1530) ispánok

Csomafáji Istuán (1530-1538) és mányiki Sztrigyi László (1530) szolgabírák

Szucsáki Miklós magister, vm.-i jegyző (1530)

1530. IV. 26. (Wass cs lt, XV/7. = WassLt 649. sz.)

Szentpáli András (1536, 1544-1546) és Gyulai János (1530-1540) ispánok

1536. V. 7. (KmJkv II. 4592. sz.), említve csak Szentpáli András ispán;

1536. X. 31. (in oppido Bonchyda, loco scilicet sedis nostre iudiciarie, $f$. III. in vig. Omn. sanct., iktári Bethlen cs lt, R. VI. fasc. 6/2, [= uo. középkori oklevelek, 186. sz.])

Csomafáji István (1530-1538) és zsombori Roth (Rod) János (1524-1525, 1536-1540) szolgabirák

1536. X. 31. (iktári Bethlen cs lt, R. VI. fasc. 6/2); [1538. XII. 29. e.] (KmJkv II. 4672. sz.), említve csak Csomafáji István szolgabíró.

\footnotetext{
${ }^{10}$ Szentegyedi Valkai Péterrel (szolgabíró: 1498, 1510, 1515-1516) és szentegyedi Valkai Istvánnal, valamint Devecseri Fábiánnal, Doboka vármegye jegyzőjével együtt kibocsátott fogott bírói oklevél.
} 
Gyulai János (1530-1540) és Kendi Antal (1540) ispánok

zsombori Roth János (1524-1525, 1536-1540) és csehi Nádasi György (1540-1548) szolgabírák

1540. III. 16. (Wass cs 1t, LIV/5. = WassLt 664. sz.)

Szentpáli András (1536, 1544-1546) és szavai Almádi Bálint (1544) ispánok

csehi Nádasi György (1540-1548) és bongárdi Zalai (Zalay) Gáspár (1544-1546) szolgabírák

1544. XI. 11. (f. III. p. Omn. sanct., in oppido Bonchyda, loco scilicet sedis nostre iudiciarie, Kemény cs malomfalvi lt, középkori oklevelek, 99. sz.)

Doboka vm. nemességének egyeteme (universitas nobilium comprovincialium, iuratorum et assessorum comitatus de Doboka)

1545. III. 24. (in oppido Zeek, f. III. p. dom. Iudica, Kemény cs malomfalvi lt, középkori oklevelek, 101. sz.)

Gyulai Mihály, exactor (1545)

1545. IX. 22. (f. III. p. Mathei ap., Beszterce v lt, I. a/1594. sz. = Berger: Regesten 1750. sz., a közölt regesztában: 1545. IX. 24., f. V. p. Mathei ap.)

Szentpáli András ispán (1536, 1544-1546)

bádoki Nádasi György (1540-1548) és bongárdi Zalai (Zalay) Gáspár (1544-1546) szolgabirák

1546. VI. 8. (in oppido Bonczyda, loco scilicet sedis nostre iudiciarie, f. III. $p$. Asc. dom., Beszterce v lt, I. a/1622. sz. = Berger: Regesten 1779. sz.); 1546. XI. 16. (in oppido Bonczyda, loco scilicet sedis nostre iudiciarie, f. III. p. Martini ep. et conf., Kemény cs csombordi lt, középkori oklevelek, 63. sz.; régi jelzet: $\mathrm{I} / 42$. sz.)

Kidei Damján magister a vm. nótáriusa (1546)

1546. XI. 16. (Kemény cs csombordi lt, középkori oklevelek, 63. sz.; régi jelzet: I/42. sz.)

Bánk Pál, Bálványos vár várnagya és kisesküllői Székely Sebestyén ispánok (1548)

bádoki Nádasi György (1540-1548) és Zsombori László (1548) szolgabírák

1548. X. 23. (f. III. p. Luce ev., MOL, Kolozsmonostori konvent hiteleshelyi lt, F17, Cista comitatuum, Comitatus Doboka, T/90.) 
EME 


\section{FEHÉR VÁRMEGYE}

Vö. VerArch 29/1899. 253-255; TTár 1907. 7. (Wertner M.); Györffy III. 95204; Iczkovits: 12. - Az alvajdák hivatalviselésére vonatkozó adatok: Engel: Arch. I. 11-15; Zsoldos: Archontológia 150-151.

Mercurius comes Bellegratae (1097)

[1097] Cat. font. II. p. 977 (Vincurius); III. p. 2158.

Gál ispán (Gallus, comes Albensis Ultrasilvanus) (1177 k.)

[1177 k.] (Bencés Főapátság Levéltára, Pannonhalma, Konventi lt, Capsarium, E 6. = DF 206822. = ÁÚO I. 69. = RegArp I/1. 128. sz.)

[Geregye nb.] Écs [Eth], erdélyi vajda és Fehér vm. ispánja (Eth voywoda et comite Albe Transsilvane) (1200)

1200 (Zárai Állami Lt, DF 286751. = RegArp I/1-3. 189. sz.)

[Kán nb.] Gyula erdélyi vajda és Fehér vm. ispánja (Jula, voiwoda et comite Albe Transilvane) (1201)

$1201($ DL 61124. = RegArp I/1-3. 195. sz. = HOkm V. 5). - Erdélyi vajda 1201-ben és 1214-ben.

[Csák nb.] Pous, hercegi tárnokmester, Fehér vm. ispánja (1227)

1227. (Prímási Levéltár, Esztergom, Esztergomi kápt. mlt, DF 238224. = CDTrans I. 146. sz. = RegArp I/1-3. 580. sz.)

Szentkirályi Gergely comes ${ }^{11}$ (1303) és Forrói Péter comes (1303) szolgabirák (iudices nobilium provincialium)

1303. X. 16. (Suky cs lt, DF 255287. = CDTrans II. 31. sz.)

${ }^{11}$ 1291-ben Benedek comes, László erdélyi alvajda helyettese (comes Benedictus gerens vices Ladizlai vicevaivodae Transsiluani), illetve Gombási Domokos comes és az itt említett Szentkirályi Gergely comes, az Erdélyország részére (v. által) az alvajda helyettese mellé kirendelt társbírák (per regnum Transiluanum iudicibus deputatis nobiscum consedentibus) bocsátanak ki 
[Vásári] Miklós erdélyi alvajda (1319-1320)

Alvajda: 1319. VIII. 8. (CDTrans II. 327. sz.); [1320. VII. 2.] (uo. II. 376377. sz.)

Ispán: 1320. II. 19. (DL 36540. = CDTrans II. 349. sz.); 1320. II. 28. (DL 36540. = CDTrans II. 350. sz.)

Miklós, az alvajda viceiudexe: 1319. VIII. 8. (DL 30364. = CDTrans II. 327. sz.)

[Demjén nb. Lapádi] Péter magister (Bökény fia) (1320) és Szentkirályi István comes (1320-1322) szolgabirák

1320. II. 19. (DL 36540. = CDTrans II. 349. sz.)

Gyógyi Gergely comes (1320-1322) és Szentkirályi István (1320-1322) szolgabírák 1320. II. 28. (DL 36540. = CDTrans II. 350. sz.)

Mihály magister erdélyi alvajda (1322-1332)

Ispán és alvajda: 1322. III. 3. (Bálintitt cs 1t, DF 292764. = CDTrans II. 421. sz.); [1322.] III. 17. (Bálintitt cs lt, DF 292764. = CDTrans II. 422. sz.); 1332. XII. 21. (Esterházy cs cseszneki lt, CDTrans II. 766. sz.)

[Gyógyi] Gergely (1320-1322) és [Szentkirályi] István (1320-1322) szolgabírák 1322. III. 3. (Bálintitt cs lt, DF 292764. = CDTrans II. 421. sz.); [1322.] III. 17. (Bálintitt cs 1t, DF 292764. = CDTrans II. 422. sz.); 1322. IV. 2. (Bálintitt cs 1t, DF 292764. = CDTrans II. 425. sz.)

[Zsámboki] Simon erdélyi alvajda (1333-1336)

Alvajda: 1333. VII. 26. (CDTrans II. 781. sz.) - 1336. X. 18. (CDTrans II. 912. sz.). - Volt alvajda: CDTrans II. 927. sz. (1337. IV. 9.)

Ispán: 1336. I. 15. (az erd. kápt. mlt, DF 277306, pag. 1, nr. 2. = ErdKLt 1033. sz. $=$ CDTrans II. 875. sz.)

Csekelaki Miklós (Lukács fia) (1336) és Szentkirályi Sándor (István fia) (13361339) szolgabirák

1336. I. 15. (az erd. kápt. mlt, DF 277306, pag. 1, nr. 2. = ErdKLt 1033. sz. $=$ CDTrans II. 875. sz.)

[Derencsényi „Orros”] Peto (Péter) erdélyi alvajda (1337-1342)

Ispán: 1339. V. 12. (DL 30375. = CDTrans II. 1033. sz.)

Szentkirályi [István fia:] Sándor (1336-1339) és Tátéi [Kemény/Kemin fia:] Márton (1339-1342) szolgabírák

1339. V. 12. (DL 30375. = CDTrans II. 1033. sz.)

oklevelet (1291. V. 8.: erd. kápt. mlt, DF 277204. = CDTrans I. 479. sz.), de kétséges, hogy ők tekinthetők Fehér vm. ispánjának, illetve szolgabíráinak. 
Forrói Mihály (1342-1348) és [Tátéi] Márton (Kemin fia) (1339-1342) szolgabirák 1342. V. 1. (az erd. kápt. mlt, DF 277334. és 277366. = CDTrans III. 86. sz.)

[Járai (Váradjai)] Péter (Mihály fia), erdélyi alvajda (1344-1349)

Ispán: 1348. VII. 1. (DL 30648. = Ub II. 56-57. = CDTrans III. 474. sz.)

Forrói Mihály (1342-1348) és Balázsfalvi László (Balázs fia) (1348) szolgabirák

1348. VII. 1. (DL 30648. = Ub II. 56-57. = CDTrans III. 474. sz.)

Mocsk Domokos erdélyi alvajda (1356-1359)

Ispán: [1357. III. 1. e.] (DL 62708. = CDTrans III. 891. sz.); 1357. III. 5. (DL 62708. = CDTrans III. 893. sz.)

Mihálcfalvi Bakó (1357) és Sülyei István (1357-1366) szolgabirák

[1357. III. 1. e.] (DL 62708. = Ub II. 135. = CDTrans III. 891. sz.); 1357. III.

5. (DL 62708. = Ub II. 135. = CDTrans III. 893. sz.)

Sülyei István (1357-1366) és Tátéi László (Márton fia) (1363-1366) szolgabirák

1363. IX. 22. (DL 73697. = TelOkl I. 126. = DRH C. XII. 174-175); 1363. X. 20. (DL 73699. = TelOkl I. 128. = DRH C. XII. 177); 1366. IX. 22. (DL 73715. = TelOkl I. 147, 1366. IX. 20-i hibás keltezéssel. = Ub II. 272-273. = DRH C. XIII. 245-246).

Swerch-i János magister, erd. alvajda (1396-1401) [Fehér vm. ispánja]

Mátyás deák (litteratus), alvajdai jegyző, alispán (1398)

1398. VII. 1. (DL 42678. = DocVal 506. $=$ ZsOkl I. 5387. sz.)

Nadányi László (1404-1406) és Sztrigyi Péter (1404-1408) erdélyi alvajdák, ispánok

Ispánok és alvajdák: 1406. I. 13. (DL 26384. = ZsOkl II/1. 4385. sz.)

Mihálcfalvi Péter (Jak fia) (1406) és Forrói Miklós (1406-1408) szolgabírák

1406. I. 13. (DL 26384. = ZsOkl II/1. 4385. sz.); 1406. III. 24. (DL 26384. = ZsOkl II/1. 4566. sz.)

[csombordi] Tompa Jakab (1408) és Forrói Miklós (1406-1408) szolgabirák

1408. I. 13. (DL 73883. $=$ TelOkl I. 328-329); 1408. I. 13. $($ DL 73884. $=$ TelOkl I. 327-328).

váraskeszi Lépes Loránd alvajda (1426-1438) [Fehér vm. ispánja?] 
Ispánlaki Benedek és Vessződi János alispánok (1435)

1435. II. 9.; 1435. VII. 1. (mindkettő jelzete: DL 12666).

Sülyei Gergely (1435) és Csügedi Miklós (1435) szolgabirák

1435. II. 9. (DL 12666).

Bagói Miske (1435) és Forrói Imre (1435) szolgabirák

1435. VII. 1. (DL 12666).

Antal deák, Fehér és Kükülló vármegyék nótáriusa (1438)

1438. V. 10. (DL 27648).

Szőkefalvi Antal deák (litteratus) és Gáldtői Péter alispánok (1451)

Ispánlaki Benedek (1451) és Hosszútelki László (1451) szolgabirák

1451. III. 19. (DL 62850. = Ub V. 312, 2727. sz., 1451. III. 12-i hibás keltezéssel).

Gáldtői Péter és Septéri Gyula ispánok [!] (1455)

Csekelaki Adorján (1455) és szentkirályi Sztrigyi (Strigy) Dénes (1455) szolgabirák

1455. VI. 12. (DL 30830).

Szentkirályi Gyula szolgabiró (1462)

1462. VIII. 10. (ENMLt, Törzsgyűjtemény, DF 253717. = EMOkl 335. sz.)

Herepei Péter ispán [!] (1471)

gáldtői Sülyei Illés (1471) szolgabiró

1471. VI. 3. (KmJkv II. 2027. sz.)

Lozsádi István (1478) és Barancskai Tamás (1478-1479) alispánok

Sülyei Mihály (1478-1479) és [sülyei] Volkányi Miklós (1478-1479) szolgabirák 1478. V. 17. (DL 45724. = Ub VII. 178, 4247. sz.)

németi Fejér Péter (1478-1483) és Barancskai/Brancsikai Tamás (1478-1479) alispánok

Sülyei Mihály (1478-1479) és [sülyei] Volkányi Miklós (1478-1479) szolgabirák

1478. IX. 15. (iktári Bethlen cs lt, DF 255038); 1478 (Iczkovits 12; a megadott jelzet nyomán - ENMLt, "gr. Kemény-cs. 1t. 293. 2." - a hivatkozott oklevelet nem sikerült fellelni); 1478. XII. 7. (DL 45760); 1478. XII. 7. (az erd. kápt. mlt, DF 277589. = ErdKLt 342. sz.); 1479. II. 9. (DL 62911); [1479.] II. 9. (eredetije egykor a Béldi cs bodolai ltban volt, szövegét Franz Zimmermann 1890. évi kéziratos másolata őrizte meg, SzNLt, Zimmermann: Urkundenbuch XIII. 36. = Ub VII. 207., 4296. sz.) 
németi Fejér Péter alispán (1478-1483)

Csongvai Gergely (1483) és Hosszútelki Osvát (1483) szolgabírák

1483. III. 12. (az oklevél egykor a Kemény cs csombordi lt-ban volt, amit 1897-ben Nagyenyeden, Alsófehér vm. levéltárában, ma pedig a KolozsNLt-ben őriznek; azonban itt az oklevél 2010-ben nem volt fellelhető. Reg.: TTár. 1907. 101).

Rákosi Gáspár és Sülyei Osvát alispánok (1494)

Béldi Benedek (1494) és Ózdi Illés (1494) szolgabirák

1494. [IV. 29. u.] (DL 26459).

Horvát Simon ispán [!] (1499)

Gáldtöi Tamás (1499) szolgabiró

1499. IV. 3. (tartalmi említés, kolozsmonostori konv. mlt, DF 275366).

csesztvei Mike [Miske?] Tamás és gáldi Cucor (Cuchor) Balázs alispánok (1510)

Kisenyedi János (1510) és csesztvei Csongvai György (1510) szolgabírák

1510. IV. 7. (Kemény József gyűjt., DF 253574. = SzOkl I. 322-323. = EMOkl 458. sz.)

Tamás, Fehér vm. nótáriusa (notarius Albensis)

1510. XI. 10. (DL 62989).

béldi Herepei Gergely alispán (1511-1515, 1522)

1511. IX. 15. (DL 62994); 1515. II. 9. (DL 63003); 1522. (DL 67262, itt említik herepei előnevét).

Gáldi Ferenc (1511) és ispánlaki Balog Pál (1511, 1522) szolgabírák

1511. IX. 15. (DL 62994).

Gáldtői Benedek (1515) és elekesi Komjátszegi István (1515) szolgabirák 1515. II. 9. (DL 63003).

Gáldtői Benedek, Gáspár Tamás, Gaspar Pesthy de eadem, Kertész János [szolgabírák?] 1515. XI. 20. (DL 63007).

Forró Tamás, (az alispán által kinevezett) helyettes alispán (1522)

tompaházi Porkoláb Józsa (1522) és [ispánlaki] Balog Pál $(1511,1522)$ szolgabírák 1522 (DL 67262).

bényei Herepei Gergely alispán (1524)

1524. VII. 17. (DL 67263). 
Fehér vármegye nemességének egyeteme (universitas nobilium de comitatu Albensi)

Említve: Herepei Gergely és Vesszódi Elek alispánok; Forrói János és Hosszútelki Zsigmond szolgabírák; Bolyai Dávid és Gáldtói Kelemen, Fehér vm. kapitányai (1525).

1525. II. 1. (DL 63036).

kövesdi Tomori István ispán (1530)

1530. XII. 31. (MOL, P 2269, K. Papp Miklós által gyűittött iratmásolatok, 163. sz., mely szerint eredetijének jelzete: Magyar Kamara lt, Publ. fasc. XVI., no. 59.)

[gyerőmonostori] Kemény Péter (1533) ispán

1533. VII. 11. (f. VI. a. Marg., Kemény cs malomfalvi lt, középkori okl., 89. sz.)

Hosszútelki Ferenc ispán (1536)

Elekesi Boldizsár és Nagyvátyi (Nagwathi) György szolgabírák (1536)

Szókefalvi [lecta per Zwkeffalwy], jegyzö (1536)

1536. V. 1. (in oct. Georg. mart., MOL, bethleni Bethlen cs lt, P 1960, Rokon és idegen családok, 2. csomó, 11. tétel, Bolyay cs, f. 7.)

Gerendi Péter ispán (1546)

1546. III. 7. (ex Olczona, in dom. ultima intervalli vid. Carnisprivi, Beszterce v lt, 1609. sz. = Berger: Regesten 1767. sz.) 


\section{HUNYAD VÁRMEGYE}

Vö. TTár 1897. 477; TTár 1905. 53; 1907. 14. (Wertner M.); VerArch 29/1899. 255-256 (Wertner M.); Csánki V. 3-249; Györffy III. 275-301; HunyadmÉvk 11/1900. 58-69; 12/1901. 137-139 (Wertner M.); Sargetia 35-36/2007-2008. 203-240 (W. Kovács A.); Zsoldos: Archontológia 271.

[Mátéházi] Márton (Máté fia) ispán (1333), Déva várnagya (1326-1338; Engel: Arch. I. 248)

Ispán: 1333. IX. 29. (DL 40652. = CDTrans II. 786. sz.). - Dévai várnagy: 1326. VIII. 1. (DL 86571. = AOkl X. 321. sz.); 1333. (DL 29427. és 107453. = CDTrans II. 789. sz.); 1334. VII. 4. (DL 98535. = CDTrans II. 816. sz.); 1335. (DL 29427. és 107453. = CDTrans II. 870/1. sz.); 1337. XI. 27. (DL 31082. = CDTrans II. 961. sz.); 1338. V. 12. (Haus-, Hofund Staatsarchiv, Bécs, Erdődy cs galgóci lt, lad. 95. fasc. 12. nr. 1. = CDTrans II. 997. sz.). - Téves azonosítása: HunyadmÉvk 12/1901. 137-139.

Aranyi István (1333) és Keresztúri Péter (Pál fia) (1333) szolgabirák

1333. IX. 29. (DL 40652. = CDTrans II. 786. sz.)

Saul magister ispán (1365)

1365. V. 7. (DL 28047. = DRH C. XII. 419-420).

[Aranyi] János (Miklós fia) ispán (1382-1384, 1387-1390) és dévai várnagy (1384, 1387-1390)

Ispán: 1382. [XII. 8-12. között (f. [---] p. Nicolai conf.)] (DL 42244); 1387. X. 16. (Török Bertalan gyüjt., DF 244533. = ZsOkl I. 260. sz.). - Dévai várnagy: 1384. V. 4. (DL 30731); 1387. II. 2. (DL 29435. = DocVal 333); 1387. X. 16. (Török Bertalan gyüjt., DF 244533. = ZsOkl I. 260. sz.). Engel: Arch. I. 300. 
[Aranyi] Miklós fia: János (1382-1384, 1387-1390) és István (1390), dévai és hátszegi várnagy, ispánok

[alpestesi] Csanádfi (Chanadini) István (1390-1395) és Harói Demeter (1390) szolgabirák

1390. I. 26. (DL 73785. = TelOkl I. 223); 1391. VIII. 8. (DL 30744).

[Zagyvafői] László magister (Miklós fia) ispán, dévai várnagy (1395)

pestesi Csanád fia: Istuán (1390-1395) és Pestesi Benche fia: Mihály (1395) szolgabirák

1395. IV. 20. (DL 42611. = HOkm VIII. 350-351, tévesen 1295-re keltezve).

János magister ispán, dévai várnagy (1397)

1397, okl., egykor a galaci Buda lt-ban (Csánki V. 246).

Kis Lőrinc alispán (1410)

Szentgyörgyi [Mihály fia: János fia:] János (1410-1413) és Alpestesi Egyed (László fia) (1410) szolgabirák

1410. XII. 2. (szárhegyi Lázár cs meggyesfalvi lt, DF 257919).

kazai Kakas Gyula ispán, hátszegi várnagy (1413)

Szentgyörgyi Mihály fia: János fia: János (1410-1413) és Pestesi Chanad fia: [István?] fia: István (1413) szolgabírák

1413. VI. 13. (DL 63051. = ZsOkl IV. 751. sz.)

Simon ispán (1431)

1431. V. 15. (csak újkori másolatban fennmaradt, minden bizonnyal hamis oklevél, mert négy szolgabírát említ és mert eredetije ismeretlen, Kemény: DiplSuppl III. 121). Vö. TudGyüjt 7/1831. 31-32. (Kenderesi F.); HunyadmÉvk 11/1900. 63 (Wertner M.).

Dengelegi Zsigmond ispán, dévai várnagy (1433)

alpestesi Csanád Fábián (1433-1439) és Kéméndi Simon (Gergely fia) (1433) szolgabirák

1433. III. 24. (DL 43950).

Rápolti Mátyás (1439-1446) és Aranyi Miklós (1439) ispánok

alpestesi Csanád Fábián (1433-1439) és Szentgyörgyi István (1439) szolgabirák

1439. III. 10. (Barcsay cs lt, DF 280909).

Rápolti Mátyás (1439-1446) és [Páznádi] Ferenc deák (1446-1452) ispánok. Rápolti egyúttal dévai (1446-1458), Páznádi hunyadi várnagy (1446-1456).

1446. VI. 29. (DL 29482). - Rápolti Mátyás, Hunyadi János dévai várnagya: 1446. VI. 29. (DL 29482); 1449. (DL 30446); 1453. I. 17. (SzNLt, Urk. II/148, DF 244791); 1458. VI. 6. (DL 30446). - Páznádi Ferenc hunyadi várnagy: 1446. VI. 29. (DL 29482); 1448. VI. 5. (DL 93096); 
1449. V. 1. (Hațeg 136, 1446. évi hibás keltezéssel); 1451. V. 8. (DL 13440. = LtKözl 1/1923. p. 118. 59. sz.); 1451. XI. 8. (Ub V. 328); 1451. XII. 8. (BrassóNLt, Brassó város levéltára, Privilegia et instrumenta publica, 115 C, DF 246929. = Ub V. 332); 1451. XII. 15. (Ub V. 333); [1454-1456] (Hațeg I. 212). - Az itt felsorolt forrásokat idézi Engel: Arch. I. 248.

Páznádi Ferenc deák alispán (1446-1452), Hunyad vár várnagya (14461456)

1452. I. 18. (Brassó v lt: Privilegia et instrumenta publica, DF 246945. = Ub V. 335-336).

Dédácsi Illés és Kéméndi Péter alispánok (1467)

alpestesi Csanád Bertalan (1467-1468) és Kéméndi Pál (1467) szolgabirák

1467. VII. 21. (iktári Bethlen cs lt, DF 255032).

Rédei János erdélyi alvajda és Körei Kristóf ispánok (1468-1469)

alpestesi Csanád Bertalan (1467-1469) és Lozsádi Benedek (Bereck fia) (Benedictus Brictii) (1468-1469) szolgabírák

1468. X. 25. (DL 45325. = HunyadmÉvk 5/1887-1888. 96-97, 1478. X. 20-i hibás keltezéssel); 1469. VII. 3. (DL 45359).

Laki (de Laak) György és Polyeni (de Polyen) János alispánok, Hunyad vár várnagyai (1477)

harói Csuka Tamás $(1477-1479,1483)$ és alpestesi Lógó Máté (1477-1483) szolgabírák

1477 (iktári Bethlen cs lt, DF 255037); 1477. V. 27. (Kemény cs csombordi lt, DF 280952. = TTár 1907. 96-97).

Vajcai (de Wayca) András és Temesvári Vince alispánok, Hunyad vár várnagyai (1479)

harói Csuka Tamás (1477-1479, 1483) és alpestesi [Lógó] Máté (1477-1483) szolgabirák

1479. III. 16. (DL 45773).

Corvin János ispán 1479-1504 (?)

1479. X. 21. (DL 27714, idézi Csánki V. 246); 1482. IV. 8. (DL 37652; DL 37653; DL 37657, idézi Pataki: Hunedoara XIX; Csánki V. 47, 246; Veress: GyulaOklt 25); 1493. VI. 15. (DL 37679, idézi Csánki V. 247-248).

Temesvári Vince és Nagy Pál ispánok (1481), Hunyad vár várnagyai (14811483)

1481. II. 13. (CDHung XI. 505-507. = Fejér: Genus 253-254); 1481. VIII. 14. (Révay cs központi 1t, 87/1/12, DF 260282); 1481. IX. 4. (Révay cs központi lt, 87/1/13, DF 260283). - Várnagyok: 1482. VII. 12 (DL 
37653, idézi Csánki V. 246); 1483. VI. 24. (DL 45957 = HunyadmÉvk 5/1887-1888. 98-99). - Temesvári Vince 1489-1491 között is várnagy.

alpestesi [Lógó] Máté (1477-1483) és Harói János (1481) szolgabirák

1481. II. 13. (CDHung XI. 505-507); 1481. VIII. 14. (Révay cs központi lt, 87/1/12, DF 260282); 1481. IX. 4. (Révay cs központi lt, 87/1/13, DF 260283).

harói Csuka Tamás (1477-1479, 1483) és alpestesi [Lógó] Máté (1477-1483) szolgabírák

1483. VI. 24. (DL 45957. = HunyadmÉvk 5/1887-1888. 98-99).

Vízközi (de Wyzkez) András ispán, Hunyad vár várnagya (1484-1488)

1488. II. 26. (Bánffy cs nemz. lt, DF 261059); 1488. VI. 17. (iktári Bethlen cs

lt, DF 255046); 1488. VII. 1. (DL 46091. = HunyadmÉvk 1/1880-1881. 68-69). - Vízközi András várnagy, Győri (de Iaurino) Dénessel együtt: 1484. VII. 2. (DL 37660. = Pataki: Hunedoara 129).

harói Kis Bálint (1488, 1508) és hosdáti Gergelyfi (Gergelfy) Bálint (1488) szolgabirák

1488. II. 26. (Bánffy cs nemz. lt, DF 261059).

harói Kis Bálint $(1488,1508)$ és Keresztúri Kelemen (1488) szolgabírák

1488. VI. 17. (iktári Bethlen cs lt, DF 255046); 1488. VII. 1. (DL 46091. = HunyadmÉvk 1/1880-1881. 68-69); 1488. VIII. 26. (DL 26442).

Temesvári Vince ispán (1489), Hunyad vár várnagya (1481-1483, 14891491)

1489. IV. 2.-1491 (Jajcza 87); 1489. VIII. 25. (Révay cs központi 1t, 87/1/15, DF 260285); 1491. VII. 9. (KmJkv II. 2737. sz.). - Hunyad vár várnagya: 1489. (DL 86798); 1491. XII. 17. (SzNLt, Urk. III/82. = DF 245389).

pestesi Bíró Máté (1489) és szentgyörgyi Czászár Demeter (1489-1494) szolgabirák

1489. VIII. 25. (Révay cs központi 1t, 87/1/15, DF 260285). - Szentgyörgyi Czászár Demeter 1489. XII. 26-án is (Jósika cs hitb. 1t).

Magyi (de Magh) Pál és Horvát János ispánok, Déva vár várnagyai (1492) szentgyörgyi Czászár Demeter (1489-1494) és keresztúri Furka Balázs (1492-1494) szolgabirák

1492. V. 1. (Magyar Mezőgazdasági Múzeum Kézirattára, III/7965, DF 287768); 1492. V. 8. (AcadRomMemSecțIst. Seria III. Tom. XVIII/1935-1936. 220-221). 
[bikali] Bikli (de Bykly) János ispán, Hunyad vár várnagya (1494-1495, 1496-1498, 1500-1504)

szentgyörgyi Császár Demeter (1489-1494) és keresztúri Furka Balázs (1492-1494) szolgabírák

1494. II. 4. (Révay cs központi lt, 87/1/13, DF 260287); 1494. VIII. 12. (DL 74248. = TelOkl II. 195-196; iktári Bethlen cs lt, DF 255060).

Bikli (de Bykly) János ispán, Hunyad vár várnagya (1494-1495, 1496-1498, 1500-1504)

1495. IX. 13. (DL 46320); 1495. X. 13. (Magyar Mezőgazdasági Múzeum Kézirattára, III/1009. sz., DF 274530). - Várnagy: 1495. IX. 13. (DL 46320, idézi Entz G.: Erdély építészete a 11-13. században. Kolozsvár 1994. 190); 1496. I. 3. (Amlacher: Broos 61-62).

hosdáti [Bíró] Bálint (1495-1496, 1505, 1507-1508) és harói Csuka Máté (14951496) szolgabirák

1495. X. 13. (Magyar Mezőgazdasági Múzeum Kézirattára, III/1009. sz., DF 274530).

[németi] Pestesi Zacharias alispán $(1496,1500)$

Bojtori György alispán (1496)

1496. II. 6. (DL 29568, idézi Csánki V. 180).

Rohodi János ispán (1496)

hosdáti [Biró] Bálint (1495-1496, 1505, 1507-1508) és harói [Csuka] Máté (14951496) szolgabirák 1496. III. 8. (DL 46336).

Kéméndi Istuán (1496) és hosdáti Bíró Bálint (1495-1496, 1505, 1507-1508) szolgabirák

1496. IV. 21., 1496. V. 1. (DL 31157).

Bojtori György alispán (1496)

1496. VI. 7. (DL 46352. = HunyadmÉvk 1/1880-1881. 72).

hosdáti [Bíró?] Bálint (1495-1496, 1505, 1507-1508) és harói Horvát [Mikló]s (1496) szolgabirák

1496. VIII. 9. (Magyar Mezőgazdasági Múzeum Kézirattára, III/7966. sz., DF 287769, részben lekopott szöveggel).

Bikli János ispán, Hunyad vár várnagya (1494-1495, 1496-1498, 15001504)

hosdáti [Bíró?] Bálint (1495-1496, 1505, 1507-1508) és harói Horvát Miklós (1496) szolgabírák

1496. XI. 8. (Magyar Mezőgazdasági Múzeum Kézirattára, III/7967. sz., DF 287770). 
Bikli János ispán, Hunyad vár várnagya (1494-1495, 1496-1498, 1500-1504, 1518-1529)

1498. V. 24. (DL 37718). - Várnagy: 1499. II. 25. (DL 30493).

Felpestesi Zakariás ispán $(1496,1500)$

Hosdáti János (1500) és harói Csuka Mátyás (1500) szolgabirák

1500. IX. 1. (Bukaresti Állami Lt, Erdélyi iratok gyüjteménye, XVII/4a. = Sargetia 18-19/1984-1985. 189).

Bikli János ispán (1494-1495, 1496-1498, 1500-1504)

1500. XI. 3. (DL 46529. = HunyadmÉvk 5/1887-1888. 99); 1500. XI. 24.

(Gyulay-Kuún cs lt, DF 252623); 1502. XI. 25. (KmJkv II. 3261. sz.); 1503. II. 21. (KmJkv II. 3272. sz.); 1503. V. 16. (Révay cs központi lt, 87/1/13, DF 260294); 1504. I. 2. (Iványi: Gyömrő 424. sz.). - Várnagy: 1500 k. (DL 32547, idézi Csánki V. 249); volt várnagy: DL 37765 (1504. VII. 28). - Bikli János 1504. X. 22. e. átadta Hunyad várát és a hozzá tartozó ispánságot Corvin János képviselőinek, enyingi Török Imrének és kisasszonyfalvi Istvánffy Istvánnak (DL 21499. = Pesty: Krassó III. 482-483).

keresztúri Veres László (1500) és harói Csikós (Chykos) Pál (1500) szolgabirák

1500. XI. 3. (DL 46529. = HunyadmÉvk 5/1887-1888. 99); 1500. XI. 24.

(Gyulay-Kuún cs lt, DF 252623).

Hosdáti Vince (1503) és Harói Máté (1503) szolgabirák

1503. V. 16. (Révay cs központi lt, 87/1/13, DF 260294).

Török András és Gáldi László ispánok (1505)

hosdáti [Bíró?] Bálint (1495-1496, 1505, 1507-1508) és Harói Bálint (1505) szolgabirák

1505. VII. 1. (DL 30965).

plávnai Benkovics Miklós ispán, Hunyad vár várnagya (1506)

1506. XII. 24. (DL 30970); 1506. XI. 29. (Amlacher: Broos 78; Nicolaus Benkowych, capitaneus Hwniadiensis).

alpestesi Balog Ferenc provisor és Zalasdi János ispánok, Hunyad vár várnagyai (1507)

alpestesi Kónya János (1507) és Csolnokosi [Mihály?] (1507) szolgabirák

1507. IV. 27. (Révay cs központi lt, DF 260457).

hosdáti [Bíró?] Bálint (1495-1496, 1505, 1507-1508) szolgabíró; Hosdáti János magister, a vm. jegyzóje $(1507 ; 1524)$

1507. VIII. 8. (DL 37797). 
Remetei Zakariás alispán (1508)

harói Kis Bálint $(1488,1508)$ és hosdáti [Bíró?] Bálint $(1495-1496,1505,1508)$ szolgabírák

1508. I. 4. (iktári Bethlen cs 1t, DF 255076).

[endrédi] Bekes János hunyadi várnagy (1509)

Csak mint hunyadi várnagy: 1509. III. 20. (Staatsarchiv Nürnberg, Brandenburgisches Archiv, Brandenburger Literalien, 1056/5. = DF 267265. $=$ Pataki: Hunedoara 139-140).

Hosdáti János (1509) szolgabíró

1509. X. 31. (DL 27590).

Folti László ispán (1510-1511)

1510. XI. 26. (DL 46960; DL 46961. = HunyadmÉvk 5/1887-1888.

100-101); 1511. II. 11. (Bukaresti Állami Lt, Erdélyi iratok gyűiteménye, XVII/4d. = Sargetia 18-19/1984-1985. 190-191); 1511. IV. 1. (uo. XVII/8. = Sargetia 18-19/1984-1985. 191); 1510. XII. 18. (Podmaniczky I. 611), alispán. - Csak mint hunyadi várnagy: 1511. XII. 20. (Staatsarchiv Nürnberg, Brandenburgisches Archiv, Brandenburger Literalien, 1056/8. = DF 267268. = Pataki: Hunedoara 154).

Hosdáti Gergely (1510-1516) és Bácsi György (1510-1511) szolgabirák

1510. XI. 26. (DL 46960; DL 46961. = HunyadmEvk 5/1887-1888. 100-101); 1511. II. 11. (Bukaresti Állami Lt, Erdélyi iratok gyüjteménye, XVII/4d. = Sargetia 18-19/1984-1985. 190-191); 1511. IV. 1. (uo. XVII/8. = Sargetia 18-19/1984-1985. 191); vö. 1514. XII. 24. (MonRustReb 305).

iregdi Patócsi Péter ispán (1516), Hunyad vár várnagya (1513-1516)

1516. I. 8. (DL 47135. = HunyadmÉvk 5/1887-1888. 102). - Patócsi Péter az erdélyi vajda különleges parancsából Hunyad vármegye hadainak vezére a mostani hadjáratban (ex speciali mandato domini waywode Transsiluanensis etc. belliductor gentium comitatus predicti Hwnyadiensis presentis exercitus; 1516. II. 26., DL 47141. = HunyadmÉvk 5/1887-1888. 103). - Csak mint hunyadi várnagy: 1513. XII. 28. (Staatsarchiv Nürnberg, Brandenburgisches Archiv, Brandenburger Literalien, 1056/9. = DF 267269); 1514 (DL 47094); vö. 1514. XII. 24. (MonRustReb 306).

Hosdáti Gergely (1510-1516) és Kisbarcsai Mihály (1516-1520) szolgabírák

1516. I. 8. (DL 47135. = HunyadmÉvk 5/1887-1888. 102); 1516. II. 26. (DL 47141. $=$ HunyadmÉvk 5/1887-1888. 103). 
Szentimrei András deák (litteratus) és Bekes (Bekws) János ispánok (15201529) és Hunyad vár várnagyai (1518-1529)

1520. VI. 19. (Török Bertalan gyüjt., DF 244563. = TTár 1907. 118). Mindketten csak mint Hunyad vár várnagyai: 1518. VIII. 14. (Staatsarchiv Nürnberg, Brandenburgisches Archiv, Brandenburger Literalien, 1056/13. = DF 267272). = Pataki: Hunedoara 177; 1520. VII. 1. (uo. 1056/17. = DF 267276. $=$ Pataki: Hunedoara 181-183).

Kisbarcsai Mihály (1516-1520) és harói Berecki Péter (1520-1536) szolgabirák 1520. VI. 19. (Török Bertalan gyüjt., DF 244563).

Kisbarcsai Mihály (1516-1520) szolgabiró

1520. IX. 20. (Jósika cs hitb. lt, DF 257630), a következőkkel együtt kiadott oklevél: Folti László, bakaji Macskási Gáspár, Kéméndi Miklós (utóbbiak azonban valószínűleg nem szolgabírák).

Szentimrei András deák és Bekes János ispánok (1520-1529) és Hunyad vár várnagyai (1518-1529)

harói Berecki Péter (1520-1536) és Naláci István (1520, 1524-1536) szolgabirák 1520. IX. 25. (DL 47374).

Szentimrei András deák és Bekes János ispánok (1520-1529) és Hunyad vár várnagyai (1518-1529)

Hosdáti Pál (1523) és harói Berecki Péter (1520-1536) szolgabirák

1523. I. 13. (DL 47486. = HunyadmÉvk 5/1887-1888. 104); 1523. IV. 14.

(DL 47499. = HunyadmÉvk 5/1887-1888. 104-105).

Szentimrei András deák és Bekes János ispánok (1520-1529) és Hunyad vár várnagyai (1518-1529)

1524. X. 11. (Révay cs központi lt 87/2/5/a, DF 260304; Révay cs központi 1t, 87/2/4, DF 260303); 1529. IV. 6. (MOL, Erdélyi kápt. hiteleshelyi lt, Prot. I. p. 9. = ErdKJkv I. 156. sz.). - Szentimrei András deák, várnagy: 1528. VII. 1.; 1529. III. 7.; 1529. VI. 28.; 1529. XII. 4. (Staatsarchiv Nürnberg, Brandenburgisches Archiv, Brandenburger Literalien, $1227 / 5 ; 1127 / 45 ; 1127 / 65 ; 1174 / 4$. = Pataki: Hunedoara 202-203, 225-227, 230-231, 239).

harói Berecki Péter (1520-1536) és Naláci István (1520, 1524-1536) szolgabírák 1524. X. 11. (Révay cs központi lt 87/2/5/a, DF 260304; Révay cs központi 1t, 87/2/4, DF 260303).

Hosdáti János deák, Hunyad vm. nótáriusa $(1507,1524)$

1524. X. 27. (Révay cs központi lt, DF 260306).

Kisbarcsai Mihály alispán (1524)

1524. XII. 3. (Gyulay-Kuún cs lt, DF 252623). 
Schtolz Georg, Hunyad vár tulajdonosának, Brandenburgi Györgynek a várnagya (1526-1529)

1526. V. 23. (DL 38093. = Pataki: Hunedoara 185-186); 1528. I. 4.; 1528. VI.

9.; 1529. XII. 4. (Staatsarchiv Nürnberg, Brandenburgisches Archiv, Brandenburger Literalien, 1225/3. = Pataki: Hunedoara 189-191; uo. 1225/2. = Pataki: Hunedoara 201-202; uo. 1117/4. = Pataki: Hunedoara 239). † 1530-ban (uo. 1043/8. = Pataki: Hunedoara 242-243).

János magister, deák, Hunyad vm. nótáriusa (1529-1531)

1529. I. 7. (MOL, Erdélyi kápt. hiteleshelyi lt, Prot. I. p. 8-9. = ENMLt, Kemény cs csombordi lt, I/35. = ErdKJkv I. 154. sz.); 1531. V. 17. (in profesto Ascens. dom., MOL, Hunyad megyei családok, R 391, 1. csomó, 8. tétel, 2ri , Hosdát, Sólyom Fekete gyüjt.-ből).

Hunyad vármegye nemességének egyeteme (universitas nobilium districtus comitatus de Hwnyad; universitas nobilium comitatus Hunyadyensis)

1528. VI. 9. (Staatsarchiv Nürnberg, Brandenburgisches Archiv, Brandenburger Literalien, 1225/2. = Pataki: Hunedoara 201-202); 1528. XI. 3. (MOL, NRA, fasc. 1530/37. = Pataki: Hunedoara 203-205).

István pap és Morzsinai Gáspár, Brandenburgi György által kinevezett várnagyok (1530-1533)

1530. IX. 20.; 1531. III. 2.; 1531. IV. 16.; 1531. V. 5.; 1532. I. 20.; 1533

(Staatsarchiv Nürnberg, Brandenburgisches Archiv, Brandenburger Literalien, 1043/8; 1127/85; 1034/3; 1034/4; 1034/11; 1050/19. = Pataki: Hunedoara 246, 254-255, 257-258, 261, 265-269, 271-279).

Barcsai Pál magister ispán (1531)

1531. I. 7. (iktári Bethlen cs 1t, R. VI. fasc. 20. no. 12. [= uo., középkori oklevelek, 149. sz.])

Horvát Bertalan, Kabos Mihály, Balátfi (Balatffy) András, egregii ispánok (1531)

1531. V. 1. (János kir. levele az ispánokhoz; Staatsarchiv Nürnberg, Brandenburgisches Archiv, Brandenburger Literalien, 1034/2. = Pataki: Hunedoara 259-260). - I. János kir. familiárisai. Hunyad vár várnagyi tisztségét ekkor a Ferdinánd-párti Brandenburgi György emberei viselik (lásd fentebb). Hunyad vára 1534 nyarától I. János királyé (Pataki: Hunedoara 284). 
Barátfi (Barthffy) András és ilyei Erdélyi (Erdely de Ilye) Mihály ispánok, Hunyad vár várnagyai (1531)

harói Berecki Péter (1520-1536) és Naláci István (1520, 1524-1544) szolgabírák

1531. XI. 21. (f. III. a. Clementis pape; MOL, Hunyad megyei családok, R 391, 1. csomó, 8. tétel, 3r, Hosdát, Sólyom Fekete gyưjt.-ből. = HunyadmÉvk 5/1887-1888. 108-109).

Felpestesi András [ispán] (1536)

harói Berecki [Péter] (1520-1536) és [Naláci] István (1520, 1524-1544) szolgabirák

1536. III. 7. (f. III. p. dom. Invocavit, iktári Bethlen cs lt, R. VI. fasc. 184. no. 1/2/9 [= uo. középkori oklevelek, 179. sz.], csonka oklevél).

Nényei (Nenyey) István és Horvát Péter ispánok, Hunyad vár várnagyai (1544)

hosdáti Gálfi (Galffy) Bálint (1544) és Naláci István (1520, 1524-1544) szolgabirák 1544. V. 27. (f. III. p. Urbani pape, MOL, Hunyad megyei családok, R 391, 1. csomó, 8. tétel, 5r, Hosdát, Sólyom Fekete gyúijt.-ből). 


\section{KOLOZS VÁRMEGYE}

Vö. TTár 1897. 479; 1907. 15-16 (Wertner M.); VerArch 29/1899. 257-266 (Wertner M.); Csánki V. 250-637; Balázs Éva: Kolozs megye kialakulása. Bp. 1939. (Település- és népiségtörténeti értekezések 3); Györffy III. 323-381; Turul 82/2009. 1. sz. 1-12. (Rüsz-Fogarasi E.); Zsoldos: Archontológia 163.

Tamás ispán (comes Clusiensis) (1177 k.)

[1177 k.] (Pannonhalmi Főapátság Lt, Konventi lt, Capsarium, 6 E. = DF 206822. = ÁÚO I. 69. = RegArp I/1. 128. sz.)

Gál (Gallus) ispán (Culusiensis comes) (1183)

1183. (Veszprém Megyei Levéltár, Szalóky cs 1t, DF 282699. = RegArp I/1. 138. sz. = HOkm I. 2; kétes hitelü oklevél).

Pázmány ispán (Pazman, comes de Kulus) (1201)

1201. (DL 40. = Rerum Hungaricarum monumenta Arpadiana. Edidit Stephanus Ladislaus Endlicher. Sangalli 1849. 399-400. = RegArp I/1. 194. sz.); 1201. (DL 61124. = HOkm V. 4-5. = RegArp I/1. 195. sz., az ispánság megnevezése nélkül; DL 100415; Zsoldos: Archontológia 163).

Kristóf ispán (comes de Clus) (1213)

[1213-ban] ispán (a forrásban tévesen curialis comes, CDTrans I. 47. sz. = RegVar p. 158, 10 [380]. sz.); ispán (CDTrans I. 54. és 61. sz. = RegVar p. 166, 32 [254]. sz. és p. 176, 61 [157]. sz.)

Beken, curialis comes de Clus (1213)

[1213] (CDTrans I. 57. sz. = RegVar p. 172, 49 [145]. sz.; RegVar p. 159, 13 [383]. sz.)

Basu, curialis comes de Clus (1214)

[1214] (CDTrans I. 68. sz. = RegVar p. 182, 80 [306]. sz.) 
[Geregye nb.] Écs (Ecce) ispán (comes de Clus) (1215)

[1215] (CDTrans I. 79. sz. = RegVar p. 196, 118 [180]. sz.)

Sebestyén ispán (comes de Clus) (1229)

[1229] (CDTrans I. 56. sz. = RegVar p. 296-297, 369 [358]. sz.)

Nucden, curialis comes (1235)

[1235] (CDTrans I. 182. sz. = RegVar p. 306-307, 388 [141]. sz.)

Nyitrai Péter ispán (1288)

1288. VI. 8. (CDTrans I. 437. sz.). Az oklevél kibocsátói: Ladizlaus vicevayuoda Transsiluanus, Petrus de Nytra comes de Kulus, Michael comes filius Laurentii, ... [Pe]trus filius Murun, et comes Petrus filius Clementis, iudices per regnum Transsiluanum constituti et eidem Ladizlao viceuoyuode in assessores ad [cert]as causas assignati.

[rődi?] Cseh Jakab ispán (1312-1314)

1312. III. 1. (Suky cs lt, DF 255259. = CDTrans II. 195. sz.); 1312. VI. 4. (DL 30598. = CDTrans II. 198/1. sz.); 1314. VII. 13. (DL 73637. = CDTrans II. 223. sz.)

Zsuki István comes (1312-1314) és [Szentpéteri] Mihály comes/magister (Dénes fia) (1312-1314) szolgabírák (iudices provincie)

1312. VI. 4. (DL 30598. = CDTrans II. 198/1. sz.); 1314. VII. 13. (DL 73637. $=$ CDTrans II. 223. sz.)

Miklós ispán (1315)

Dezméri Miklós (Mikola fia) (1315) szolgabíró

1315. XI. 9. (DL 28717. = CDTrans II. 255. sz.)

[Fonói] János magister, besztercei, kolozsi és kolozsvári [!] ispán (1317)

1317. II. 24. (DL 58447. = CDTrans II. 268. sz.). - 1324 e. az erdélyi részek kapitánya, királynéi pohárnokmester (DL 2239. = CDTrans II. 482. sz.)

Zsuki Mihály ispán (1324)

1324. III. 19. (Kemény cs csombordi 1t, DF 280942. = CDTrans II. 479. sz.)

Rimai Miklós magister (Miklós fia), kolozsvári [!] ispán, létai várnagy (1331), Kolozs vm. ispánja (1332)

1331. VIII. 8. (DL 75391. = CDTrans II. 715. sz.); 1332. I. 20. (DL 76008, idézi Engel: Arch. I. 249).

Mérai Miklós ispán (1334)

1334. II. 17. (DL 73643. = CDTrans II. 796. sz.) 
[Györgyfalvi] „Henke” Péter comes (1334) és [rödi] Cseh (Cheh d) Mihály (1334, 1340) szolgabírák

1334. VIII. 10. (Kemény cs malomfalvi lt, DF 257789. = CDTrans II. 825. sz.)

Miklós ispán (1337; az előzővel vagy a következővel azonos)

1337. XII. 3. (Wass cs lt, DF 252742. = CDTrans II. 963. sz.); 1337. XII. 10.

(Wass cs 1t, DF 252742. = CDTrans II. 966. sz.) - Miklós, Kolozs vm. ispánjának 1337 k. oklevele a MOL nyilvántartása szerint egykor a Teleki cs marosvásárhelyi lt-ban (DL 74439).

[Zsuki] Miklós (Albert fia) ispán (1339)

1339. II. 10. (oklevél egykor a kolozsmonostori konv. mlt-ban, CDTrans II. 1025. sz.)

Miklós comes ispán (1339; talán az előzővel azonos)

[1339?]. II. [24]. (DL 74436. = CDTrans II. 1030. sz.)

Zsuki János comes [Domokos fia] (1340-1349, 1353-1359, 1363-1367) és Cseh (d) Mihály comes [rődi Jakab fia] $(1334,1340)$ szolgabirák; István comes (1340), alszolgabiró

[1340?] XI. [22.] (DL 74434. = CDTrans III. 35. sz.)

[cegei ifj.] Vas Miklós magister, ispán (1347-1349)

1347. VI. 13. (DL 41042. = CDTrans III. 396. sz., Miklós magister, ispán); 1349. [XI. 4. e.] (Wass cs 1t, DF 252758. = CDTrans III. 542. sz.); 1349. XI. 12. (Kemény cs malomfalvi lt, DF 252681. = CDTrans III. 547. sz.). Egykori kolozsi ispán: 1367. III. 24. (Wass cs 1t, DF 252776. = HOkl 281-282. = WassLt 144. sz.)

Zsuki János comes [Domokos fia] (1340-1349, 1353-1359, 1363-1367) és Dénes (1347) szolgabirák

1347. VI. 13. (DL 41042. = CDTrans III. 396. sz.)

Zsuki János (Domokos fia) (1340-1349, 1353-1359, 1363-1367) és [ródi] Cseh Dezső (1349) szolgabírák

1349. [XI. 4. e.] (Wass cs 1t, DF 252758. = CDTrans III. 542. sz.); 1349. XI. 12. (Kemény cs malomfalvi lt, DF 252681. = CDTrans III. 547. sz.)

Gombási (dictus de Gunbasi) János magister, ispán (1351)

Bogár János [Korpádi Márton fia: Beke fia] (1351) és [Szucsáki?] János (István fia)

(1351) szolgabirák

1351. X. 19. (DL 73664. = CDTrans III. 622. sz.) 
[Járai] Gál magister (Pascha fia) ispán (1353)

[Zsuki] János (Domokos fia) (1340-1349, 1353-1359, 1363-1367) és Cseh László [rödi Cseh Jakab fia] (1353) szolgabirák 1353. IX. 25. (DL 73667. = CDTrans III. 731. sz.)

[almakeréki Apafi] János magister (Gegus fia) ispán (1355)

[Zsuki] János (Domokos fia) (1340-1349, 1353-1359, 1363-1367) és ródi Cseh (d) László [Jakab fia] (1353-1355) szolgabírák

1355. VIII. 26. (DL 50335. = CDTrans III. 809. sz.)

[Járai] György magister (Jakab fia) ispán (1358-1359)

[Zsuki] János (Domokos fia) (1340-1349, 1353-1359, 1363-1367) és [Járai?] Miklós (Tamás fia) (1358-1359) szolgabirák

1358. VIII. 1. (DL 73676. = CDTrans III. 1031-1032. sz.); 1359. I. 16. (DL 73678. $=$ CDTrans III. 1055. sz.)

[cegei Vas] „Veres” Péter alispán (1359)

1359. [XII. 8.]. (Wass cs 1t, DF 252718. = HOkl 262-263. = WassLt 123. sz.)

[Szucsáki?] [Szentmihálytelki?] András (Miklós fia) (1360-1361) és [Györgyfalvi?]

[Tuzsoni?] János (Mihály fia) (1360-1361) szolgabirák

1360 (Kemény cs malomfalvi lt, DF 257794. = DRH C. XI. 453-454); 1361.

II. 10. (DL 73686. = TelOkl I. 119).

Zsuki János (Domokos fia) (1340-1349, 1353-1359, 1363-1367) és Budai György (1363) szolgabirák

1363. IV. 12. (DL 28914. = DRH C. XII. 146-148); 1363. IX. 23. (DL 73698. = TelOkl I. 126-127).

[Györgyfalvi] „Henke" Mihály (1364-1367) és Zsuki János (Domokos fia) (1340$1349,1353,1355,1358,1359,1363-1367)$ szolgabirák

1364. II. 6. (DL 73703. = TelOkl I. 131); 1365. II. 28. (DL 73709. = TelOkl I. 138-139).

[Nádasi?] László magister (László fia) ispán (1366)

Zsuki János (Domokos fia) (1340-1349, 1353, 1355, 1358, 1359, 1363-1367) és [Györgyfalvi] „Henke” Mihály (1364-1367) szolgabírák

1366. IV. 28. (a kolozsmonostori konv. mlt, DF 275184. = DRH C. XIII. 51-52); 1366. IX. 9. (DL 36944. = DRH C. XIII. 242); 1367. III. 24. (Wass cs 1t, DF 252776. $=$ HOkl 281-282. $=$ WassLt 144. sz.) 
[Bethlen] Gergely magister (János fia) ispán (1373)

Patai János (Imre fia) $(1373-1388,1390)$ és Mócsi Istuán (Miske fia) (1373) szolgabirák

1373. IX. 28. (Kemény cs malomfalvi lt, DF 257795. = DRH C. XIV. 414).

ősi Jankafi János (Iohannes filius Iwanka) ispán (1378)

Patai János (Imre fia) $(1373-1388,1390)$ és Tótházai Benedek (Tamás fia) (13781381, 1388) szolgabírák

1378. VIII. 25. (DL 73752. = TelOkl I. 179); 1378. IX. 15. (DL 73753, 73755. és 73754. = TelOkl I. 180, 180-181, 181).

Turóci Jakab ispán (1381)

Patai János (Imre fia) $(1373-1388,1390)$ és Tótházai Benedek (Tamás fia) (13781381, 1388) szolgabírák

1381. IX. 11. (DL 73768. = TelOkl I. 201-202).

Patai János (Imre fia) (1373-1388, 1390) és Frátai Imre (Beke fia) (1386) szolgabírák 1386. II. 7. (Wass cs lt, DF 252843. = HOkl 314-315. = WassLt 193. sz.)

Iklódi Gergely magister (Beke fia) ispán (1388-1390)

1388. I. 22. (Kemény cs malomfalvi lt, DF 257800); 1388 (f. IV. post [---], DL 36946); 1389. I. 27. (DL 73782. = TelOkl I. 216); 1389. XII. 29. (Suky cs lt, DF 255239); 1390. IV. 27. (DL 73786. = TelOkl I. 223-224); 1390. VI. 1. (DL 73787. = TelOkl I. 224).

Patai János (Imre fia) $(1373-1388,1390)$ és Tótházai Benedek (Tamás fia) (13781381, 1388) szolgabírák

1388. I. 22. (Kemény cs malomfalvi lt, DF 257800); 1388 (f. IV. post [---], DL 36946).

Györgyfalvi „Henke” László (1389-1393, 1398-1402) és Mérai Bálint (1389) szolgabirák

1389. I. 27. (DL 73782. = TelOkl I. 216); 1389. XI. 3. (DL 73784. = TelOkl I. 222); 1389. XII. 29. (Suky cs lt, DF 255239).

Györgyfalvi „Henke” László (1389-1393, 1398-1402) és Patai János (Imre fia) (1373-1388, 1390) szolgabírák

1390. IV. 27. (DL 73786. = TelOkl I. 223-224); 1390. VI. 1. (DL 73787. = TelOkl I. 224); 1390. VII. 13. (DL 73789. = TelOkl I. 227); 1390. IX. 25. $($ DL 73790. $=$ TelOkl I. 227). 
Györgyfalvi "Henke” László (1389-1393, 1398-1402) és Gesztrágyi László (János fia) (1391-1393, 1398) szolgabírák

1391. [IV. 2. u.] (Suky cs 1t, DF 255267); 1393. X. 3. (DL 26989. = ZsOk1

I. 3123. sz.); 1393 (csonka, napi keltezése kiszakadt; Kemény cs malomfalvi lt, DF 257801).

Szomordoki László magister (Domokos fia) ispán (1396)

Nádasi Domokos (Lơrinc fia) (1396) és Mócsi Miklós (István fia) (1396) szolgabirák

1396. II. 2. (Kornis cs lt, DF 257661, korábbi jelzete: DL 37287).

Kályáni Mihály magister (Dénes fia) ispán (1398)

1398. III. 27. (DL 28767. = ZsOkl I. 5229. sz.); 1398. IV. 24. (DL 73818. = TelOkl I. 263-264); 1398. X. 9. (Wass cs lt, DF 252813. = WassLt 230. sz.); 1398. X. 9. (Wass cs 1t, DF 252814. = WassLt 231. sz.); 1398. XI. 6. (Wass cs 1t, DF 252817. = WassLt 234. sz.); 1398. XI. 20. (Wass cs lt, DF 252818. = WassLt 235. sz.); 1398. XII. 18. (Wass cs lt, DF 252819. = WassLt 236. sz.); 1398. XII. 18. (Wass cs lt = WassLt 237. sz.)

Frátai Péter (Gál fia) (1398, 1403-1407) és Gesztrágyi László [János fia] (1391, 1398) szolgabirák

1398. III. 27. (DL 28767. = ZsOkl I. 5229. sz.); 1398. IV. 24. (DL 73818. = TelOkl I. 263-264).

Györgyfalvi „Henke” László (1389-1391, 1398-1402) és Szomordoki László (13981407) szolgabirák

1398. X. 9. (Wass cs lt, DF 252813. = WassLt 230. sz.); 1398. X. 9. (Wass cs 1t, DF 252814. = WassLt 231. sz.); 1398. XI. 6. (Wass cs lt, DF 252817. = WassLt 234. sz.); 1398. XI. 20. (Wass cs lt, DF 252818. = WassLt 235. sz.); 1398. XII. 18. (Wass cs lt, DF 252819. = WassLt 236. sz.); 1398. XII. 18. (Wass cs lt, DF 252820 = WassLt 237. sz.); 1402. V. 10. (Kemény cs malomfalvi lt, DF 257859).

Frátai Péter magister (Gál fia) (1398, 1403-1407) és Szomordoki László (13981407) szolgabírák

1403. VI. 6. (ebben az oklevélben tévesen Patai Gál fia: Péter szerepel; 18. századi másolat, ENMLt, kászoni br. Bornemisza cs lt, 3 [régi jelzet: Fő osztály, II. Gyerőffy jószágokat tárgyazó levelek 32. sz.] 163 ${ }^{\mathrm{r}-\mathrm{v}}$ ); 1404. VI. 18. (DL 28131); 1404. VII. 30. (DL 73858. = TelOkl I. 298). 1405. X. 28. (DL 73863. = TelOkl II. 408-409); 1406 (DL 73869); 1407. I. 5. $($ DL 73870. $=$ TelOkl I. 314-315).

Szucsáki János (László fia) (1408) és Dezméri Tamás (1408-1410, 1413-1417) szolgabirák

1408. VI. 6. (DL 73893. = TelOk1 I. 340-341). 
D[rági?] Ferenc és Angyali (dictus de Angal) István ispánok, létai várnagyok (1408)

Szucsáki János (László fia) (1408) és Dezméri Tamás (1408-1410, 1413-1417) szolgabirák

1408. IX. 5. (DL 73897. = TelOkl I. 342; Franciscus de D[--- et] Stephanus de Angal dictus, castellani de Leta, comites de [Clu]s, TelOkl I. 342).

Dezméri Tamás (1408-1410, 1413-1417) és szucsáki [Tatár] Péter (1410, 14151417) szolgabírák

1410. VII. 23. (Dezméri Tamás és tévesen: Macskási Péter, Wass cs lt, DF 252860. = WassLt 289. sz.; Dezméri Tamás és Szucsáki Péter, DL 28141. = ZsOkl II/2. 7783. sz.)

Dezméri Tamás (1408-1410, 1413-1417) és Macskási Péter (1410, 1422-1424, 1425, 1429) szolgabírák

1410. IX. 17. (DL 73916. = TelOkl I. 366; DL 73915. = TelOkl I. 367; DL 73917. $=$ TelOkl I. 367-368).

papfalvi Csoronk Benedek (1413-1414) és Dezméri Tamás (1408-1410, 1413-1417) szolgabírák

1413. II. 1. (a kolozsmonostori konv. mlt, DF 275223. = Ub III. 561); 1413.

V. 17. (DL 28147. = ZsOk1 IV. 602. sz.); 1413. VI. 28. (DL 28148. = ZsOkl IV. 793. sz.)

Péter alispán (1414)

papfalvi Csoronk Benedek (1413-1414) és Dezméri Tamás (1408-1410, 1413-1417) szolgabírák

1414. XI. 7. (DL 73944. = TelOkl I. 402-403).

Dezméri Tamás (1408-1410, 1413-1417) és csutaki [helyesen: szucsáki] (de Chutak, valószínüleg elírás de Zvchak helyett) Tatár (d) Péter (1410, 1415-1417).

1415. V. 22. (DL 43283; DL 73951. = TelOk1 I. 413-415).

Bagdi Demeter alispán (1416)

Dezméri Tamás (1408-1410, 1413-1417) és szucsáki Tatár Péter (1410, 1415-1417) szolgabirák

1416. I. 29. (Wass cs lt, DF 252873. = ZsOkl V. 1479. sz. $=$ WassLt 328. sz.)

Esztári Imre ispán (1416)

Dezméri Tamás (1408-1410, 1413-1417) és szucsáki Tatár Péter (1410, 1415-1417) szolgabirák

1416. X. 21. (Wass cs lt, DF 252876. $=$ ZsOkl V. 2374. sz. $=$ WassLt 334. sz.) 
Drági Jakab ispán (1417-1419)

1417. V. 19. (DL 62788. = ZsOkl VI. 452. sz.); 1417. VI. 30. (DL 62791. = ZsOkl VI. 623. sz.); 1417. VI. 30. (DL 62790. = ZsOkl VI. 624. sz.); 1419. III. 29. (DL 73972. = TelOkl I. 437-438. = ZsOkl VII. 229. sz., utóbbi III. 24-i keltezéssel); 1419. IV. 19. (DL 73973. = TelOkl I. 438-439. = ZsOkl VII. 324. sz.); 1419. V. 3. (DL 73974. = TelOkl I. 439. = ZsOkl VII. 391. sz.); 1419. VII. 19. u. (DL 73979. = TelOkl I. 441. = ZsOkl VII. 783. sz.). - Egyidejüleg Léta (1419, KL) és Hátszeg (1422 e., HD) várnagya.

Dezméri Tamás (1408-1410, 1413-1417) és szucsáki Tatár Péter (1410, 1415-1417) szolgabirák

1417. V. 19. (DL 62788. = ZsOkl VI. 452. sz.); 1417. VI. 30. (DL 62791. = ZsOkl VI. 623. sz.); 1417. VI. 30. (DL 62790. = ZsOkl VI. 624. sz.)

Mócsi Miklós (Sandrinus fia) (1419-1424, 1429-1435) és Budai Gergely (1419) szolgabirák

1419. III. 29. (DL 73972. = TelOkl I. 437-438. = ZsOkl VII. 229. sz., utóbbi III. 24-i keltezéssel; Suky cs lt, DF 255271); 1419. IV. 19. (DL 73973. $=$ TelOkl I. 438-439. = ZsOkl VII. 324. sz.); 1419. V. 3. (DL 73974. = TelOkl I. 439. = ZsOkl VII. 391. sz.); 1419. VII. 19. u. (DL 73979. = TelOkl I. 441. = ZsOkl VII. 783. sz.)

Mócsi Miklós (Sandrinus fia) (1419-1424, 1429-1435) és Macskási Péter (1410, 1422-1424, 1425, 1429) szolgabirák

1422. IX. 30. (DL 73996. = TelOkl I. 462).

Sárdi András alispán (1423-1424)

1423. III. 17. (DL 36944. = ZsOkl X. 292. sz.); 1423. XII. 15. (DL 74002. = TelOkl I. 466-467. = ZsOkl X. 1524. sz.); 1424. IV. 11. (Kemény cs malomfalvi lt, DF 257807); 1424. VII. 19. (Kemény József gyüjt., DF 253489. = Transilvania 5/1872. 233-234).

Mócsi Miklós (Sandrinus fia) (1419-1424, 1429-1435) és Macskási Péter (1410, 1422-1424, 1425, 1429) szolgabírák

1423. III. 17. (DL 36944. = ZsOkl X. 292. sz.); 1423. V. 27. (DL 26770. $=$ ZsOkl X. 679. sz.); 1423. XII. 15. (DL 74002. = TelOkl I. 466-467. $=$ ZsOkl X. 1524. sz.); 1424. IV. 11. (Kemény cs malomfalvi lt, DF 257807).

Péter, nótárius

1423. XII. 15. (DL 74002. = ZsOkl X. 1524. sz.)

Macskási Péter (1410, 1422-1424, 1425, 1429) és Szucsáki János (Jakab fia) (1424, 1425) szolgabírák

1424. VII. 19. (Kemény József gyüjt., DF 253489. = Transilvania 5/1872. 233-234). 
Mócsi Miklós (Sandrinus fia) alispán (1425)

Mócsi Miske (1425, 1426-1427) és Szomordoki Imre (1425, 1426-1427, 1434-1435) szolgabírák

1425. VI. 6. (a kolozsmonostori konv. mlt, DF 275241. = TTár 1897. 342. =

KmLt 114. sz.); 1425. VIII. 15. (DL 74013. = TelOkl I. 481-482; ez utóbbi oklevél sérült és benne csak Mócsi Miklós ispán és Szomordoki Imre szolgabíró neve olvasható; a másik szolgabíró neve kiszakadt). - Mócsi Miklós Kolozs vm. szolgabírája (1419-1424, 1429-1435).

Macskási Péter (1410, 1422-1424, 1425, 1429) és Szucsáki János (Jakab fia) (1424, 1425) szolgabírák

1425. X. 24. (DL 28189).

Mócsi Miske (1425, 1426-1427) és Szomordoki Imre (1425, 1426-1427, 1434-1435) szolgabirák

1426. IX. 26. (DL 28191).

Haranglábi Gál ispán (1426-1427)

1426. X. 9. (DL 28192); 1427. VI. 18. (DL 62804).

Mócsi Miske (1425, 1426-1427) és Szomordoki Imre (1425, 1426-1427, 1434-1435) szolgabírák

1426. X. 9. (DL 28192); 1427. VI. 18. (DL 62803-62804); 1427. VI. 19. (Suky cs lt, DF 255256).

Komjátszegi Miklós (1429) és Macskási Péter (1410, 1422-1424, 1425, 1429) szolgabírák

1429. I. 12. (DL 28197); 1429. III. 17. (Wass cs 1t, DF 252935. = WassLt 393. sz.)

Dobokai Miklós és [palotai, gyéresi] Cibak László ispánok (1429-1430)

1429. IV. 6. (DL 28198); 1430. III. 22. (DL 74046. = TelOkl I. 525).

Komjátszegi Miklós (1429) és Macskási Péter (1410, 1422-1424, 1425, 1429) szolgabírák

1429. IV. 6. (DL 28198); 1429. IV. 20. (Suky cs lt, DF 255257).

Mócsi Miklós (Sandrinus fia) (1419-1424, 1429-1435) és újbudai Kis Gergely (1429-1434) szolgabírák

1429. VIII. 31. (DL 28199; sérült oklevél, az egyik szolgabíró neve kiszakadt: Mócsi Sandrinus fia: Miklós és [Újbudai Kis Gergely?] szolgabírák); 1429. XI. 30. (Suky cs lt, DF 255225); 1429. XII. 14. (DL 105488); 1430. III. 22. (DL 74046. = TelOkl I. 525); 1430. VI. 7. (Kemény cs malomfalvi lt, DF 257808); 1431. IV. 18. (DL 28207). 
Károlyi Lanch [= László] és Kömörői (de Kemere) János ispánok (1431)

1431. X. 10. (Wass cs lt, DF 252946. = WassLt 420. sz.)

Mócsi Miklós (Sandrinus fia) (1419-1424, 1429-1435) és újbudai Kis Gergely (1429-1434) szolgabírák

1431. X. 10. (Wass cs lt, DF 252946. = WassLt 420. sz.); 1434. III. 3. (DL 74056. $=$ TelOkl I. 534).

Indali Pál alispán (1434-1435)

1434. XI. 24. (DL 44014); 1435. V. 4. (a kolozsmonostori konv. mlt, DF 275256. $=$ Dani 318-320. - Hibás regesztája: KmLt 136. sz.). - Indali Pál Doboka vm. alispánja (1435).

Mócsi Miklós (Sandrinus fia) (1419-1424, 1429-1435) és Szomordoki Imre (1425, 1426-1427, 1434-1435) szolgabírák

1434. XI. 24. (DL 44014); 1435. V. 4. (a kolozsmonostori konv. mlt, DF 275256. = Dani 318-320); 1435. VIII. 3. (DL 74061. = TelOkl I. 542).

szamosfalvi Gyerőfi László ispán (1439)

Frátai János (1439) és Andrásházi „Nagy" Gergely (1439-1446) szolgabirák

1439. IV. 22. (a kolozsmonostori konv. mlt, DF 275262. = KmLt 147. sz., 1437. IV. 18-i téves keltezéssel).

csomafáji Erdélyi (Erdely) Péter és Sárosi János ispánok (1441)

Novaji Fülöp (1441-1446) és Andrásházi „Nagy” Gergely (1439-1446) szolgabírák

1441. VIII. 23. (DL 26781).

[---] és Bádoki László12 ispánok (1445)

1445. [I. 10. k.] ([f. [---] Pauli her.], Suky cs lt, DF 255297).

Andrásházi „Nagy” Gergely (1439-1446) és Novaji Fülöp (1441-1446) szolgabirák

1445. [I. 10. k.] ([f. [---] Pauli her.], Suky cs lt, DF 255297); 1445. V. 26. (Suky cs lt, DF 255295).

Somai Gergely és Simon [?] alispánok (1445)

Andrásházi „Nagy” Gergely (1439-1446) és Novaji Fülöp (1441-1446) szolgabirák 1445. XI. 10. (Suky cs lt, DF 255296).

\footnotetext{
${ }^{12}$ Bádoki László 1444. XII. 15-i oklevélben (Wass cs 1t, DF 252955. = WassLt 435. sz.) tévesen Kolozs megyei ispánként szerepel. A hivatkozott oklevél valójában Doboka vm. hatóságának a kiadványa, mert Bonchidán kelt, és az említett két szolgabíró - Sztrigyi Gyögy és Fodorházi András - korábban is Doboka vm. szolgabírájaként szerepelt.
} 
alispánok (1446)

Andrásházi „Nagy" Gergely (1439-1446) és Novaji Fülöp (1441-1446) szolgabírák 1446. III. 16. (DL 74096. = TelOkl II. 23-24).

szamosfalvi "Gyerő fia” János ${ }^{13}$ (1449-1451) és Szomordoki Domokos (1449) ispánok

Újbudai Balázs (1449-1450) és novaji Sztrigyi István (1449-1450) szolgabirák 1449. XI. 12. (Suky cs lt, DF 255299).

szamosfalvi „Gyerő fia” János (1449-1451) és Szalmatercsi János (14501451) alispánok

1450. VI. 3. (DL 14375); 1451. VII. 21. (DL 36403, p. 49. nr. 1. = KmJkv I. 971. sz.). - Szalmatercsi János egyidejúleg Doboka vm. ispánja (1451).

Újbudai Balázs (1449-1450) és [novaji] Sztrigyi István (1449-1450) szolgabírák 1450. VI. 3. (DL 14375).

Szomordoki Domokos (1451) és Patai János (1451) szolgabirák

1451. VII. 21. (DL 36403, p. 49. nr. 1. = KmJkv I. 971. sz.)

[szamosfal]vi „Gyerő fiai” Mihály és János [(al)ispánok?] [1451u. ?]

Patai [János] [1451 u. ?] és szucsáki Vas Fábián [1451 u. ?-1458] szolgabírák (145[-], DL 74435). A keltezés évét jelölő utolsó szó, illetve az ünnep megjelölése is kiszakadt. Az oklevél azonban 1451. VII. 21. u. kelhetett, ekkor ugyanis még szamosfalvi Gyerőfi János és Szalmatercsi János az alispán (KmJkv I. 971. sz.).

Szentpáli Pál és Szancsali Mihály ispánok (1458)

szucsáki [Vas] Fábián (1451 u. ?-1458) szolgabíró

1458. VI. 28. (Suky cs lt, DF 255278).

Dobai Gergely és inakfalvi Székely Tamás ispánok (1458)

szucsáki [Vas] Fábián (1451 u. ?-1458) és frátai Szentes György (1458) szolgabírák 1458. VII. 26. (DL 74142. = TelOkl II. 68).

patai Dezső Antal ispán (1460)

Szucsáki Nagy Pál szolgabíró (1460)

1460. VIII. 7. (DL 28844). - Dezső Antal egyidejúleg Doboka vm. ispánja (1460).

Szomordoki Domokos (1461) alispán

1461. XII. 23. (KmJkv I. 1652. sz.)

\footnotetext{
${ }^{13}$ Engelnél (Arch. I. 250) Gyerőfi János ispán neve helyett tévesen Gyerőfi László szerepel.
} 
bongárdi Szilágyi János és kolozsvári Sértő Péter magister, illetve Bereck várnagy, ispánok (1462)

szucsáki Nagy Kelemen $(1462-1465,1468)$ és frátai Báncsa Imre (1462) szolgabirák

1462. III. 17. (Bánffy cs nemz. lt, DF 260989. = BánfOkl II. 50-52); 1462. V.

5. (Jósika cs hitb. lt, DF 257583). - Szilágyi János és Sértő Péter egyidejűleg Torda vm. ispánjai (1462).

hesdáti „,[Ba?]ncza” Imre (1462?) szolgabíró

1462. X. 6. e. (KmJkv I. 1658. sz. = DL 28992; a közölt regesztában: Hosdat-i [...]ucza Imre).

Iklódi Márton (1465) és Iklódi István (1465) ispánok

Hesdáti Imre (1465-1468) és [szucsáki] Nagy Kelemen (1462-1465, 1468) szolgabirák

1465. VI. 26. (ENMLt Törzsgyűjtemény, DF 253603. = EMOkl 343. sz.).

- Iklódi Márton és Iklódi István egyidejúleg Doboka vm. ispánjai.

kercsedi (de Kerczeth) Székely Tamás (1465-1466) és bácsi Porkoláb János (1465-1466) alispánok

Somai Gergely (1465-1466) és Hesdáti Imre (1465-1468) szolgabirák

1465. IX. 25. (DL 62885); 1466. I. 9. (Suky cs lt, DF 255275, a szolgabírákat említi, illetve a két alispán közül csak bácsi Porkoláb Jánost); 1466. VI. 11. (Jósika cs hitb. lt, DF 257586).

Mucz-i magister [?!] fia: Simon és kercsedi Székely Tamás alispánok (14651466)

Somai Gergely (1465-1466) és Hesdáti Imre (1465-1468) szolgabírák 1466. VII. 16. (DL 36944).

Rápolti György ispán (1467); Szucsáki Mátyás alispán (1467)

1467. VI. 23. (DL 27031). - Az oklevél szerint Rápolti az alispánságot Szucsákira ruházta át.

zalai Nagy György Pál (Paulus Georgius Magny [!] de Zala) és Deák (litteratus) Bálint ispánok (1468)

Hesdáti Imre (1465-1468) és szucsáki Nagy Kelemen $(1462-1465,1468)$ szolgabirák 1468. VII. 20. (Suky cs lt, DF 255170).

méhesi Tót István alispán (1476)

botházi Porkoláb Mihály (1476, 1482, 1484, 1491) és Szucsáki Mihály (1476) szolgabirák

1476. V. 22. (Suky cs lt, DF 255205).

zsombori Móré Gergely alispán (1478)

Györgyfalvi „Henke” János (1478) és Szentpáli Mihály (1478, 1484, 1491, 1493) szolgabírák

1478. XI. 18. (Kornis cs lt, DF 257682, korábbi jelzete: DL 37305). 
szucsáki Nagy Benedek (1482-1488) és Bozkúti János alispánok (1482)

[budai] Budai Pál (1482) és botházi Porkoláb Mihály (1476, 1482, 1484, 1491) szolgabírák

1482. IX. 18. (DL 74218).

szucsáki Nagy Benedek alispán (1482-1488)

1484. IV. 7. (DL 105520); 1488. V. 14. (DL 36944).

botházi Porkoláb Mihály (1476, 1482, 1484, 1491) és Szentpáli Mihály (1478, 1484, 1491, 1493) szolgabírák

1484. IV. 7. (DL 105520).

szopori Szentgyörgyi György $(1488,1492)$ és szucsáki Porkoláb Demeter (1488) szolgabírák

1488. V. 14. (DL 36944).

[szucsáki] Sándorházi György alispán (1491-1492, 1497)

1491. V. 11. (Kemény cs malomfalvi lt, DF 257828); 1492. XI. 21. (Kemény cs csombordi lt IV/8, DF 280954. = TTár 1907. 102).

Szentpáli Mihály (1478, 1484, 1491, 1493) és botházi Porkoláb Mihály (1476, 1482, 1484, 1491) szolgabirák

1491. V. 11. (Kemény cs malomfalvi lt, DF 257828).

sárdi Budai István (1492-1493) és szopori Szentgyörgyi György $(1488,1492)$ szolgabirák

1492. XI. 21. (Kemény cs csombordi lt IV/8, DF 280954. = TTár 1907. 102).

[balázsfalvi] Cserényi Pál ispán (1493)

sárdi Budai István (1492-1493) és rődi Cseh Péter (1493) szolgabírák

1493. I. 23. (Kemény cs malomfalvi lt, DF 252658. és 257833).

Nagy Tamás alispán (1493)

sárdi Budai István (1492-1493) és ródi Cseh Péter (1493) szolgabírák

[1493 k., DL 36347 $\left.7^{14}\right]$.

Farky [? = Zsuki] Pál ispán

1494. VIII. 11. (a kolozsmonostori konventnél tett bevallásban: Paulus Farky, comes comitatus de Colos, Kemény cs malomfalvi lt, DF 257836).

\footnotetext{
${ }^{14}$ Eredeti, rongált papíron, melynek alsó része leszakadt és elveszett. A keltezés Losonci László (1493-1494) és bélteki Drágfi Bertalan (1493-1498) erdélyi vajdák és székely ispánok, illetve Geréb László erdélyi püspök (1475-1501) egyidejü hivatalviselése alapján történt. Sárdi Budai István és rődi Cseh Péter egyidejű szolgabíróságáról 1493. I. 23-ról (DF 252658) ismeretes adat, de ekkor még Cserényi Pál Kolozs vm. ispánja.
} 
Kemény Péter (1493), Gyerőfi Balázs (1493), Szentpáli Mihály (1478, 1484, 1491, 1493) és [sárdi] Budai Istoán (1492-1493) szolgabírák

1493. VI. 14. (fogott bírák is, vélhetőleg közülük csak ketten szolgabírák, DL 36398, p. 137-138, nr. 2. = KmJkv II. 2872. sz.)

[szucsáki] Sándorházi György (1491-1492, 1497) és [budai, óbudai] Budai Lázár (1497) alispánok

Hacaki Dénes (1497) és Györgyfalvi „Henke” Salatiel (1497, 1513-1514) szolgabirák

1497. VI. 7. (Mike Sándor gyújt., DF 253613); 1497. XI. 8. (DL 27087).

Gesztrágyi Benedek és Várkői (Warkoy) Amade György ispánok (1499)

Gesztrágyi Ábrahám (1499) és rődi Cseh Gergely (1499) szolgabirák

1499. II. 27. (Kemény cs malomfalvi lt, DF 252665. és 257841).

újbudai Nagy (Nagh) Domokos (1509) szolgabíró

1509. XII. 15. (KmJkv II. 3525. sz.)

[gyerő]monostori Kemény Péter (egregius) [ispán] (1510-1516, 1521)

szucsáki Sándorházi Ambrus alispán (1510)

1510. I. 2. (Kemény cs malomfalvi lt, DF 252688).

gyerőmonostori Kemény Péter (1510-1516, 1521, 1528) és Drági Márton (1512-1514) ispánok

1512. III. 3. (Jósika cs hitb. lt, DF 257623); 1512. III. 31. (Jósika cs hitb. lt, DF 257624); 1512. VII. 8. (DL 65459); 1513. V. 18. (Kemény cs malomfalvi lt, DF 252669. és 257849); 1513. VII. 20. (ENMLt Törzsgyüjtemény, DF 253763); 1514. I. 4. (Kolozsvár v lt, DF 281253).

inaktelki Gyerôfi Ferenc (1512) és Szentpáli János $(1512,1525)$ szolgabirák

1512. III. 3. (Jósika cs hitb. lt, DF 257623); 1512. III. 31. (Jósika cs hitb. $1 \mathrm{t}, 257624)$.

Györgyfalvi „Henke" Salatiel (1497, 1513-1514) és [sárdi] Budai Vince (1513-1514, 1521-1522) szolgabírák

1513. V. 18. (Kemény cs malomfalvi lt, DF 252669. és 257849); 1513. VII. 20. (ENMLt Törzsgyüjtemény, DF 253763); 1514. I. 4. (Kolozsvár v lt, DF 281253). - Györgyfalvi „Henke” Salatiel egykori szolgabíróként említve: 1514. XII. 13. (Kornis cs 1t, DF 257693).

gyerőmonostori Kemény Péter (1510-1516, 1521, 1528) és Tótprónai Cherubin (Cherwbyn) (1514-1521) ispánok

1514. XII. 13. (Kornis cs lt, DF 257693); 1516. V. 28. (Suky cs lt, DF 255316). 
papfalvi Csoronk Benedek (1514) és [nagyszentmihálytelki] Olcsárdi János (1514, 1518) szolgabírák

1514. XII. 13. (Kornis cs 1t, DF 257693. - A kiegészítés forrása: KmJkv II. 3698. sz.)

Nádasi Ferenc (1516-1517, 1533) és Botházi Péter (1516-1517) szolgabírák 1516. V. 28. (Suky cs lt, DF 255316).

Tótprónai Cherubin (Cherwbyn) (1514-1521) ispán

Nádasi Ferenc (1516-1517, 1533) és Botházi Péter (1516-1517) szolgabírák 1517. IV. 29. (Kemény cs malomfalvi lt, DF 252670. és 257852).

nagyszentmihálytelki Olcsárdi János szolgabíró (1514, 1518)

1518. XII. 10. (KmJkv II. 3691. sz.); 1518. XII. 29. (KmJkv II. 3698. sz.)

gyerőmonostori Kemény Péter (1510-1516, 1521, 1528) és Tótprónai Cherubin (Cherwbyn) (1514-1521) ispánok

[sárdi] Budai Vince (1513-1514, 1521-1522) és Györgyfalvi „Kis” Salatiel (1521$1522,1525,1530)$ szolgabirák

1521. V. 15. (Suky cs 1t, DF 255317).

sárdi Budai Gergely ispán (1522-1526)

1522. VI. 18. (Kemény cs csombordi lt, DF 280941. = TTár 1907. 107-108); 1522. VIII. 29. (KmJkv II. 3871. sz.); 1523. IX. 30. (Toldalagi cs lt, DF 257539); 1524. X. 19. (Jósika cs hitb. lt, DF 257632); 1524. VI. 15. (Mike Sándor gyüjt., DF 253622); 1525. X. 4. (Kemény cs malomfalvi lt, DF 252672. és 257855); 1526. II. 7. (Suky cs lt, DF 255218).

sárdi Budai Vince (1513-1514, 1521-1522) és Györgyfalvi "Kis (minor)” „Henke” Salatiel (1521-1522, 1525, 1530) szolgabírák

1522. VI. 18. (Kemény cs csombordi lt, DF 280941. = TTár 1907. 107-108);

1523. IX. 30. (Toldalagi cs lt, DF 257539).

Miklós deák (litteratus), Kolozs vm. nótáriusa (1524-1530)

1524. II. 1. (DL 26855).

Bikali Ambrus (1524) és Szentmiklósi Nagy Ambrus (1524) szolgabírák 1524. VI. 15. (Mike Sándor gyűjt., DF 253622).

Kolozs vármegye nemességének egyeteme (universitas nobilium comitatus de Kolos)

1524. X. 19. (Jósika cs hitb. lt, DF 257632). 
Szentpáli János (1512, 1525) és Györgyfalvi ifjabb (iunior) „Henke” Salatiel (1521-1522, 1525, 1530) szolgabirák

1525. X. 4. (Kemény cs malomfalvi lt, DF 252672. és 257855); 1526. II. 7. (Suky cs lt, DF 255218).

gyerővásárhelyi Gyerőfi László ispán (1527-1528)

1527. IX. 27. (f. VI. a. Mich. arch., MOL, R 293, Megyei iratok, 5. d, No. 2., f. 2.)

[gyerővásárhelyi] Gyerőfi László (1527-1528) és Kemény Péter (1510-1516, 1528) ispánok

1528. V. 17. (in dom. Rogat., MOL, Családi fondtöredékek, P 2257, No. 214. Gyerőffy család iratai [régi jelzet: R 319, no. 716], f. 1.)

szamosfalvi Mikola László (1530-1533) és farnasi Veres Márton (15301533) ispánok

1530. X. 26. (KmJkv II. 4326. sz.); 1533. II. 12. (f. IV. a. Valentini mart., Suky cs lt, középkori oklevelek, 188. sz. = Petrichevich 368, 1950. sz.)

várcai Vajda Vasile (1530) és Györgyfalvi „Kis (minor)” „Henke" Salatiel (1521$1522,1525,1530)$ szolgabírák

Miklós deák, a vm. esküdt jegyzője (1524-1530)

1530. X. 26. (KmJkv II. 4326. sz.)

Nádasi Ferenc (1516-1517, 1533) és szamosfalvi Sándor András (1533) szolgabirák

1533. II. 12. (f. IV. a. Valentini mart., Suky cs lt, középkori oklevelek, 188. sz. $=$ Petrichevich 368, 1950. sz.)

Kolozs vármegye nemességének egyeteme (universitas nobilium comitatus de Colos)

1539. II. 5. (f. IV. p. Purif. Marie virg., Suky cs 1t, középkori oklevelek, 204. sz.)

Kolozs vármegye nemességének egyeteme (universitas nobilium comitatus de Colos)

sárdi Hacaki Gáspár, a vm. protonotariusa (1544)

1544. V. 21. (f. IV. vid. in profesto Ascens. dom., Jósika cs hitb. lt, középkori oklevelek, 25. sz.) 


\section{KÜKÜLLŐ VÁRMEGYE}

Vö. VerArch 29/1899. 269-271 (Wertner M.); TTár 1907. 21 (Wertner M.);

Csánki V. 839-971; Györffy III. 533-564; Zsoldos: Archontológia 167.

Rafael ispán (Rachael [!], comes de Kuckelluu) (1214)

[1214] (CDTrans I. 72. sz. RegVar p. 189, 99 [325]. sz.)

Ders magister ispán (1331)

[Haranglábi] Domokos (Bezter fia) (1331) és [Ebesfalvi] Oppor (László fia) (1331) szolgabírák

1331. XI. 6. (DL 73649. = TelOkl I. 44. = CDTrans II. 722. sz.)

Perényi (de Puren) Péter ispán (1344)

[Bordi] Burd (1344) és [Szalók nb. Darlaci] Simon bán fia: Miklós (1344) szolgabírák

[1344. III. 17. e.] (ENMLt Törzsgyűitemény, DF 253649. = CDTrans III. 190. sz.); 1344. III. 18. (Direcția Arhivelor Naționale Istorice Centrale, Béldi cs mezőméhesi lt, DF 290936. = CDTrans III. 192. sz.)

[Kállói] Ubul magister, nótárius [?], Újvár várnagya, ispán (1361) 1361. (DL 29694. = DRH C. XIII. 672-674).

Balad magister (1361) és [Szentpáli] László (Barabás fia) (1361) szolgabirák 1361. $($ DL 29694. $=$ DRH C. XIII. 672-674).

István ispán, küküllővári alvárnagy (1407)

Cikmántori János (Jakab fia) (1407) és Radnóti Bord László (1407) szolgabirák 1407. VIII. 31. (DL 73879. = TelOkl I. 325. = ZsOkl II/2. 5703. sz.)

Bogáti Imre ispán (1416)

1416. IX. 9. (DL 30772. = ZsOkl V. 2286. sz.); 1416. X. 7. (DL 30772. = ZsOkl V. 2342-2343. sz.); 1416. X. 21. (DL 30772. = ZsOkl V. 2375. sz.) 
Bükkösi János (Boncha fia) (1416) és kerelői Tatár Lőrinc (1416) szolgabírák

1416. IX. 9. (DL 30772. = ZsOkl V. 2286. sz.); 1416. X. 7. (DL 30772. = ZsOkl V. 2342. sz.); 1416. X. 21. (DL 30772. = ZsOkl V. 2375. sz.)

[---] ispán, küküllővári várnagy (1439)

péterfalvi Burján [---] (1439) és [---] Mihály (1439) szolgabirák

1439. XI. 11. (Mike Sándor gyűjt., DF 253594. = EMOkl 277. sz.)

[váraskeszi] Lépes Loránd ispán (1434)

1434. VII. 23. (SzNLt, Urk. II/105. = DF 244749. = Ub IV. 528). - Egyidejűleg erdélyi alvajda (1415-1438).

Antal deák, Fehér és Kükülló vármegyék nótáriusa (1438)

1438. V. 10. (DL 27648).

Herepei István, Jakab és Mihály alispánok (1448)

héderfájai Lökös Domokos (1448) és petendi Burján Pál (1448) szolgabirák

[1448.] III. 20. (DL 74107. = TelOkl II. 35).

péterfalvi Porkoláb András alispán, [küküllővári] várnagy (1478), ispán (1479)

abosfalvi Szakál Imre (1478-1479) és Korógyi András (1478-1479) szolgabirák

1478. IV. 25. (DL 62907); 1479. III. 10. (DL 45771. = Ub VII. 208, 4298. sz.)

szókefalvi Kis Illés szolgabíró $(1499,1513,1532)$

1499. XI. 24. (Szász Nemzeti és Szeben v lt, Urk. II/648. = DF 245292).

ádámosi Porkoláb Imre szolgabíró (1507)

1507. IV. 29. (KmJkv II. 3417. sz.)

Vécsei (de Wece) Balázs és mikeszászi Horvát Mihály ispánok (1513)

szancsali Sulyok Demeter (1513) és szókefalvi Kis Illés $(1499,1513,1532)$ szolgabirák

1513. VII. 6. (Bánffy cs nemz. lt, DF 261103).

Vessződi (de Vezeud) János alispán (1518 e.)

Megölését említik: 1518. VII. 14. (DL 31016).

Haranglábi Miklós (1532-1536) és eceli Tabiási (Thabyassy) János (1532) ispánok

szókefalvi Kis Illés (1499, 1513, 1532) és szancsali Sulyok Menyhárt (1532) szolgabirák

1532. X. 16. (f. IV. in Galli conf., Nagy Jenő gyüjt. 19. sz.) 
Haranglábi Miklós (1532-1536) és Pálosi (Palossy) Gergely (1536) ispánok [abosfalvi] Rákosi Mihály (1536-1538) és Ipolt János (1536) szolgabírák

1536. XI. 22. (f. IV. a. Kath. virg., MOL, bethleni Bethlen cs lt, P 55, 10. csomó, 7, Szentmiklós, f. 188; másolata: uo. P 55, 30. csomó, Birtokjogi iratok, 37. tétel; Bethlen cs, vegyes iratok, 1536, f. 1-2).

Porkoláb György ispán (1538)

abosfalvi Rákosi Mihály (1536-1538) szolgabíró

1538. I. 8. (f. III. p. Epiph. dom., MOL, Erdélyi iratok, 1527-1938, R 298,

Vegyes erdélyi iratok, 9. d, Évrendezett iratok, 1527-1600). 
EME 


\section{TORDA VÁRMEGYE}

Vö. VerArch 29/1899. 307-308; TTár 1907. 170-171 (Wertner M.); Csánki V. 638-838; Zsoldos: Archontológia 273.

Gerendi Miklós (Péter comes fia) ispán (1310-1312, 1326)

1310. VI. 9. (DL 30595. = CDTrans II. 168. sz.); 1312. IV. 19. (DL 30594. = uo. II. 197. sz.); 1326. VII. 24. (DL 40487. = uo. II. 565. sz.)

Járai Domokos (Marcellus fia) (1310) szolgabíró (iudex provincie)

Zalai (d) Pál (1310) alszolgabíró (viceiudex)

1310. VI. 9. (DL 30595. = CDTrans II. 168. sz.)

Iwahun magister ispán (1319)

1319. XII. 18. (DL 73655. = CDTrans II. 343. sz.)

Kochka Mihály fia: Pál magister (1321) szolgabíró

1321. XI. 4. (DL 27829. = CDTrans II. 410. sz.)

Jakab magister ispán (1335)

[Járai?] László (Dénes fia) (1335) és Toldalagi Barnabás (1335) szolgabirák

1335. VIII. 18. (DL 96182. = AOkl XIX. 516. sz.)

[Zsuki] Mihály (Albert fia) ispán (1338)

Járai László (1338) és Thorda (1338e.) szolgabirák

[1338. III. 12. e.]. (erdélyi kápt. mlt, DF 277282-277283. = CDTrans II. 987. sz.)

Olaszi Cine (d) Péter fia: Marót magister, ispán (1350)

1350. IX. 25. (DL 98564. = CDTrans III. 573. sz.) 
Túri János ispán (1366)

Szindi Sándor (1366) és Bogáti Herceg Péter (1366) szolgabirák

[1366.] IV. 30. (a kolozsmonostori konv. mlt, DF 275185. = DRH C. XIII. $55-56)$.

Szentmártoni János (Beke fia) (1383) és Indali Gál (1383) szolgabirák 1383. III. 30. (DL 73774. = TelOkl I. 208).

[mezőcsáni] Csáni János (Torda fia) (1392) és Szentmártoni Miklós (Pál fia) (1392) szolgabírák

1392. I. 22. (DL 73796. = TelOkl I. 234-235. = ZsOkl I. 2371. sz.)

Komjátszegi Imre (1401-1408) és Szengyeli László (1401) szolgabírák

1401. II. 14. (DL 73841. = TelOkl I. 279. = ZsOkl II/1. 878. sz.)

Komjátszegi Imre (1401-1408) és Szentmargitai Miklós (1408) szolgabirák

1408. VII. 10. (DL 73895. = TelOkl I. 341. = ZsOkl II/2. 6214. sz.)

Szarkadi László (Miklós fia) (1409-1421) és Komjátszegi Miklós (1409-1418) szolgabirák

1409. III. 11. (DL 73899. = TelOkl I. 349-350. = ZsOkl II/2. 6641. sz.)

Szilvási Bertalan ispán (1415)

1415. IV. 8. (DL 73949. = TelOkl I. 410. = ZsOkl V. 465. sz.)

Szarkadi [László?] (1409-1421) és Komjátszegi Miklós (1409-1418) szolgabírák

1418. III. 14. (DL 73963. = TelOkl I. 430, 1418. III. 13. körüli keltezéssel. = ZsOkl VI. 1641. sz.)

Szarkadi László (Miklós fia) (1409-1421) és [mezöcsáni] Csáni Mihály (János fia) (1421) szolgabirák

1421. X. 20. (a kolozsmonostori konv. mlt, DF 275236. = ZsOkl VIII. 1072. sz.)

Köte (Kethe) János ispán (1430-1436)

Szalmás (Salmas) Miklós (1430) és Szentiváni Péter (1430) szolgabirák 1430. I. 2. (DL 28201).

Köte János (1430-1436) és Sülyei Illés (1436) ispánok

petlendi Solymos (Solmus) Miklós (1436) és Keresztúri László deák (1436-1440) szolgabírák

[1436.] IX. 8. (a kolozsmonostori konv. mlt, DF 275261. = KmLt 144. sz.) 
Meggyesfalvi Alárd fia: Jakab és Szentkirályi Semjén ispánok (1440)

Keresztúri László deák (1436-1440) és Egresi István (1440) szolgabírák

1440. IV. 4. (DL 13535); 1440. IV. 18. (DL 13537); 1440. VI. 6. (DL 13553).

Szentkirályi Oláh János és Méhesi Balázs alispánok (1440)

Keresztúri László deák szolgabíró

1440. VI. 24. (KmJkv I. 253. sz.)

rődi Cseh Miklós ispán (1444-1446)

Szengyeli Domokos (1444, 1453) és Császári (Cassari) Mihály (1444) szolgabirák

1444. III. 16. (DL 74085. = TelOkl II. 13-14); 1444. V. 4. (DL 74086. = TelOkl

II. 14); 1444. VI. 1. (DL 74087. = TelOkl II. 15); 1444. VI. 15. (DL 74088. = TelOkl II. 15-16).

rődi Cseh Miklós (1444-1446) és Pál deák (1446) ispánok

szindi Tancs (Danch) Péter (1446-1448) és Toldalagi Tamás (1446) szolgabirák

1446. V. 9. (DL 74098. = TelOkl II. 26).

Hadrévi (de Hudrey) „Bíró” László és Nádasdi János ispánok (1446)

szindi Tancs (Danch) Péter (1446-1448) és Toldalagi Tamás (1446) szolgabirák

1446. IX. 26. (DL 74099. = TelOkl II. 27).

Csúcsi Miklós (1447), patai Dezső György és János (1447-1448) ispánok szindi Tancs (Thanch) Péter (1446-1448) és Szengyeli/Szentgyörgyi [!] Mátyás

(1447, 1462-1463) szolgabirák

1447. II. 20. (DL 74101. = TelOkl II. 27-28, Szentgyörgyi Mátyás neve valószínűleg elírás Szengyeli helyett); 1447. III. 13. (DL 74102. = TelOk1 II. 28-29, Szengyeli Mátyásként említve).

Herepei Márk (1448), [somkeréki] Erdélyi Miklós (1448), patai Dezső János és György (1447-1448) ispánok (1447-1448)

szindi Tancs (Danch) Péter (1446-1448) és Pókai András (1447-1448) szolgabirák 1448. III. 4. (DL 74105. = TelOkl II. 34). - Erdélyi Miklós (1448-ban), illetve Herepei Márk (1446-1450 között) egyidejűleg erdélyi alvajda; Pókai András Torda vm. alispánja (1448).

patai Dezső János (1447-1448), Pókai András (1448), Septéri Gyula (1448, 1453), Hadrévi László (1448) és sáromberki Nagy Imre (1448) alispánok [szindi] Tancs (Danch) Péter (1446-1448) és Pókai András (1447-1448) szolgabírák

1448. V. 6. (DL 74109. = TelOkl II. 37). 
Mezőcsáni László (Thorda fia [= „Tordafi”]) és egresi Császári Mihály alispánok (1449)

Szengyeli Miklós (1449) és petlendi Veres Pál (1449) szolgabirák 1449. I. 13. (iktári Bethlen cs lt, DF 255025).

[vajdaszentiványi] Földvári Imre (1453), szamosfalvi Gyerőfi János (1453) és Septéri Gyula $(1448,1453)$ alispánok

Szengyeli Domokos $(1444,1453)$ és petlendi Solymos Zsigmond (1453) szolgabirák 1453. XII. 17. (DL 74123. = TelOkl II. 52-54).

Járai Miklós és Margai László ispánok (1461)

Szentgyörgyi János (1461) és [mezöcsáni] Csáni László (1461-1462) szolgabirák 1461. X. 5. (DL 107468).

bongárdi Szilágyi János és kolozsvári Sértő Péter magister, Pókai Bereck várnagy, ispánok (1462)

Csáni László (1461-1462) és Szengyeli Mátyás (1447, 1462-1463) szolgabirák

1462. III. 22. (DL 29052). - Szilágyi János és Sértő Péter egyidejűleg Kolozs vm. ispánjai (1462).

Ficsor (Phicor) János és Porkoláb Bereck ispánok (1463)

Szengyeli Mátyás (1447, 1462-1463) és Petlendi Pál (1463) szolgabírák 1463. [V. 1. u.] (DL 29052).

Ficsor János és Porkoláb Bereck, illetve bongárdi Szilágyi János ispánok (1463 k.)

Szengyeli Mátyás (1447, 1462-1463) és Petlendi Pál (1463k.) szolgabírák [1463 k.] (DL 29052).

Ficsor János és [Pókai „Porkoláb”] Bereck várnagy, ispánok [1463k.]

Szengyeli [Mátyá]s [1463 k.] és Petlendi Pál [1463 k.] szolgabirák

[1463 u.] (DL 29052).

Porkoláb Demjén és Szengyel Mátyás alispánok (1469)

1469. III. 15. (KmJkv I. 1851-1852. sz.)

kerelői Erdély János ispán (1484-1487)

1484. III. 22. (Kemény József gyűjt., DF 253523. = EMOkl 393. sz.); 1485.

XI. 28. (Wass cs 1t, DF 252971. = WassLt 474. sz.); 1486. II. 13. (Kornis cs lt, DF 257685, korábbi jelzete: DL 37308); 1486. X. 9. (DL 37066. = Cercetări Istorice 10-12/1934-1936. 19-21. = Ub VII. 458., 4669. sz.); 1487. XII. 3. (DL 74233. = TelOkl II. 171-172). 
Komjátszegi János (1484) és szengyeli Sárosi Albert (1484) szolgabírák

1484. III. 22. (Kemény József gyüjt., DF 253523. = EMOkl 393. sz.)

túrcsáni Nagy János (1485-1487) és szentgyörgyi Csegedi Gergely (1485-1487, 1493-1494) szolgabírák

1485. XI. 28. (Wass cs lt, DF 252971. = WassLt 474. sz.); 1486. II. 13. (Kornis cs lt, DF 257685, korábbi jelzete: DL 37308); 1486. X. 9. (DL 37066. = Cercetări Istorice 10-12/1934-1936. 19-21. = Ub VII. 458); 1487. XII. 3. $($ DL 74233. $=$ TelOkl II. 171-172).

szentannai Tót Balázs és Lukai (Lwkay) Bernát ispánok (1493)

szentgyörgyi Csegedi (Chegedy) Gergely (1485-1487, 1493-1494) és túrcsáni Szurda (Zwrda) Istoán (1493-1494) szolgabirák

1493. VII. 29. (Bánffy cs nemz. lt, DF 260914).

Székely Miklós és Sásvári Miklós ispánok (1494)

szentgyörgyi Csegedi (Chegedy) Gergely (1485-1487, 1493-1494) és túrcsáni Szurda István (1493-1494) szolgabírák

1494. VII. 21. (DL 36638; Jósika cs hitb. lt, DF 257561). - Az oklevélben tévesen Szonda István szerepel.

Zsombori Péter és keresztesi Cseszelicki (Kyzeleczky) János ispánok (1499) Szentgyörgyi Péter erdélyi vajda 1499. I. 1-jei parancsa Torda vm. nemeseihez és más rendü-rangú embereihez (in comitatu nostri honoris de Thorda) az ispánok kinevezéséről: DL 65442. Idézi Mályusz: Erdélyi társadalom 31, 91 (117. jegyzet).

Szengyeli Mátyás $(1503,1512)$ szolgabíró

1503. V. 4. (Wass cs 1t, DF 255393. = WassLt 516. sz.)

losonci Dezsőfi János és szancsali Sulyok Benedek ispánok (1508)

petlendi Egresi Tamás (1508-1512) és szengyeli Sárosi Bernát (1508) szolgabírák 1508. XI. 6. (DL 74330. = TelOkl II. 305-307).

Túri Benedek (1512) és Gerendi László (1508-1525) ispánok

petlendi Egresi Tamás (1508-1512) és Szengyeli Mátyás $(1503,1512)$ szolgabírák

1512. VII. 5. (Bánffy cs nemz. 1t, DF 260916); Gerendi László 1525. I. 2. e. is ispán (iktári Bethlen cs lt, DF 255125); Egresi Tamás szolgabíró: 1517. X. 26. (MonRustReb 438).

Barcsai Pál magister, ítélőmester, ispán (1525-1526)

Kinevezése: 1525. I. 2. (iktári Bethlen cs lt, DF 255125); 1525. VIII. 20. (uo. DF 255129); 1526. IV. 2. (Berger: Regesten I. 871. sz.); 1526. V. 19. (DL 36644). 
Túri Benedek ispán (1527)

1527. VII. 22. (Kolozsvár v lt, Div. 21/5. Kiss András ny. főlevéltáros kéziratos regesztáiból).

Kecseti Balázs (1530-1536) és Gerendi Márton (1536) ispánok

1530. IX. 12. (f. II. p. Nat. virg., MOL, Erdélyi iratok, 1527-1938, R 298, Vegyes erdélyi iratok, 9. d, Évrendezett iratok, 1527-1600), említve csak Kecseti Balázs ispán; 1536. V. 7. (KmJkv II. 4592. sz.), említve csak Gerendi Márton ispán; 1536. XII. 4. (in Barbare virg., iktári Bethlen cs lt, R. VI. fasc. 304/6 [= uo. középkori oklevelek, 188. sz.])

Kobza Ferenc (1536) és Komjátszegi István (1536) szolgabirák

1536. XII. 4. (iktári Bethlen cs lt, R. VI. fasc. 304/6). 


\section{SZEMÉLYTÖRTÉNETI ADATTÁR}

[---] Mihály, Küküllő vm. szolgabírája (1439). 82

abosfalvi cs: Szakál

ádámosi cs: Porkoláb

Agmánd nemzetség: Péterházi, Zsuki

Ákos nemzetség: Torockói

Alárdfi (=Meggyesfalvi, de Megesfalua, Marosszék; TD; Csánki V. 427-428, 745-746)

- Jakab („Alárd fia”), Torda vm. isp. (1440). Meggyesfalvi Alárd fia ([1430?]: KmJkv I. 29. sz.; 1448: TelOkl II. 33); Ercsei (TD) Alárd fia (1447: uo. II. 29); Alárd (1448: uo. II. 33), Péter (1451: KmJkv I. 995. sz.), László (1461: uo. I. 1600. sz.) és Torockói Péterné Dorottya apja (uo. I. 1474: 2146. sz.). Petén (TD) birtokos (1447: TelOkl II. 27), 1448-ban marosszéki birtokokat szerez meg (uo. II. 35). Ügyvéd (1440: KmJkv I. 282. sz.). 1459-ben néhai (uo. I. 1352. sz.). 87

Almádi ([macskási], KL, BSz; Csánki V. 428-429)

- Mihály, B-Szolnok vm. szolgabírája (1495). Almádi Illés fia, Doboka és B-Szolnok vm.-ben birtokos (1491, 1493: KmJkv II. 2719, 2851. sz.); macskási (KL, 1493: uo. II. 2851. sz.); csepegőmacskási. 1504-ben néhai; Máté apja (1504: uo. II. 3318. sz.). 29
Almádi (szavai, DO; Sándor I.: A szavai Almádi család. In: Genealógiai Füzetek 8/1910. 73-74)

- Bálint, Doboka vm. isp. (1544). Egregius, Vécs (TD) várnagya (1530: KmJkv II. 4285. sz.). Szilkeréki (Jósika cs hitb. 1t, 1529. XII. 22.). I. János kir. Magyarkályán, Oláhkályán, Visa (KL, 1528. XI. 15.: Jósika cs hitb. lt), Báni, Harasztos, Katona (KL, Jósika cs hitb. lt, 1529. XII. 22.), Móric (1529: DO, Kádár-Tagányi V. 201) birtokokban adományoz neki jószágrészeket. Oláhpénteken és Szükeréken birtokos (BSz, uo. V. 426, 532). 47

almakeréki cs: Apafi

Alpestesi (HD; Csánki V. 150)

- Egyed (László fia), Hunyad vm. szolgabírája (1410). 56

alpestesi cs-ok: Balog, Csanádfi, Kónya, Lógó

András (Miklós fia), Kolozs vm. szolgabírája (1360-1361) 1. Szucsáki (v. Szentmihálytelki?) András

Andrásházi (KL; Csánki V. 429-430)

- „Darabos” Mihály (István fia), magister, B-Szolnok vm. isp. (1397-1400). Mérán (KL) birtokos (1418: TelOkl I. 435-436). Magyarfrátán (KL) telket vesz zálogba (1410: uo. I. 360-361). 1389-ben andrásházi (KL) jószágrész eladása ellen tiltakozott (uo. I. 216). 
[Losonci?] László erd. vajda özvegyének pénzt hitelezett (1392: uo. I. 239). Eml. 1422-ben (uo. I. 462). 26

- „Nagy” Gergely, Kolozs vm. szolgabírája (1439-1446). Felesége: Kéméndi Marcus Péter leánya: Dorottya (HD, 1439: KmJkv I. 170. sz.); ügyvéd (1450: uo. I. 854. sz.). 74-75

Angyali (dictus de Angal; KL?)

- István, Kolozs vm. isp., Léta (KL) várnagya (1408). Angyali István „valószínüleg azonos - vagy rokon az 1435-ben említett Cluswar-i Enghel (d) István mesterrel" (DL 36897. = A pannonhalmi Szent-Benedek-rend története. Bp. 1905. III. 315, jegyzet; Engel: Arch. I. 249). 71

Antal deák, Fehér és Küküllő vm.-ék nótáriusa (1438). Kornéltelkén (KK) jószágrészt vásárol Gyógyi (Dyog-i) Lukács fia: István fia: László fiától: Mihálytól (DL 27648). Talán azonos $\rightarrow$ Szőkefalvi Antal deákkal, Fehér vm. alispánjával (1451). 82

[Apafi] ([almakeréki], BSz; Engel: Gen., Becsegergely nem, elágazás és 2. tábla: Apafi)

- János magister (Gegus fia), Kolozs vm. isp. (1355). Almakeréki Gegus fia: János (1374: DRH. C. XIV. 458), Péter és László apja (1367: Ub II. 287). Udvari lovag, jobbágyai és birtoktalan famulusai felett ítélkezhet (1366: DL 5450; idézi: Engel: Arch. II. 484). Újfalun (FH) lakóháza és malma volt, ezüst serlegeit, fegyvereit említik (1345: CDTrans III. 250. sz.). Almakerék, Keresd, Bese, Rudály, Földszín, Újfalu stb. (FH) birtokban volt része (1349: uo. III. 534. sz., relator: Lackfi András székely isp.; 537, 541, 543, 548. sz.). Nagyfalun és Décsén (BSz) birtokos (1353: uo. III. 722. sz.). Bethleni és almakeréki (1364: DL 41571; DRH. C. XII. 292). Lackfi Dénes erd. vajda mellett részt vett I. Lajos kir. bulgáriai hadjáratában (1365: uo. XII. 430; uo. XII. 437). Vajdai ember (1366: uo. XIII. 15). 68

- Gegus magister, B-Szolnok vm. szolgabírája (1325). Apa fia: almakeréki Miklós fia (1298: CDHung VI/2. 152; 1315: CDTrans II. 243. sz.). János, Miklós és Gergely apja (1345: uo. III. 251. sz.). Fehér és B-Szolnok vm.ben birtokos (Almakerék, Újfalu stb. 1305, 1340: uo. II. 44. sz.; III. 8. sz.). Királyi és vajdai ember (1326, 1328: uo. II. 571, 623. sz.). Szécsényi Tamás erd. vajda familiárisa (1329: uo. II. 658. sz.). 25

\section{Apor 1. Oppor}

Aranyi ([bencenci, piskinci], HD; Csánki V. 75, 125, 150-151, 163; Engel: Gen., Aranyi, bencenci, piskinci)

- [„Porkoláb”] István („Malac” Miklós fia), Bálványos vár (BSz) várnagya (1377: DRH. C. XV. 346-348), dobokai isp. (1378-1379), Hunyad vm. isp., Déva és Hátszeg várnagya (1390). János miles és István, Viskenth-i (= Piskinci)/Benchenc-i Miklós fiai (1387, 1391: ZsOkl I. 214. sz., DocVal 404). [Aranyi] Miklós fia: István (1386: DL 29439). Aranyi Porkolab István (Gyulay-Kuún cs lt, 1439: DF 252610). $\rightarrow$ Miklós apja. (Vö. HunyadmÉvk 11/1900. 63). 34

- István (de Aran), Hunyad vm. szolgabírája (1333). 55

- János magister (Piskinci/Bencenci "Malac” Miklós fia; 1395, 1400, 1408: ZsOkl I. 3804. sz., Ub III. 250; ZsOkl II/2. 6030. sz.), Hunyad vm. isp. (1382-1384, 1387-1390), dévai várnagy (1384, 1387-1390; DL 30731; DocVal 326; ENMLt, Török B. gyüjt., DF 244533; TelOkl I. 223), hátszegi várnagy (1390; uo. I. 223; Ortvay: Temes I. 195). 55-56 
- Miklós (de Aran), Hunyad vm. isp. (1439). $\rightarrow$ István fia (1428: iktári Bethlen cs lt, DF 255024). Arany, [Alsó- és Felső]kitiden, Piskincen birtokos, harcol a törökök ellen (1439: GyulayKuún cs lt, DF 252610, idézi Engel). 56

Bácsi (HD; Csánki V. 151)

- György, Hunyad vm. szolgabírája (1510-1511). 61

bácsi cs: Porkoláb

Bádoki (DO; Csánki V. 430-431)

- Antal, Doboka vm. isp. (1448). Domokos fia (1440: KmJkv I. 206. sz.), $\rightarrow$ Mihály apja (1473: uo. I. 2088. sz.). Szentmártonmacskáson (DO) jószágrészt vesz zálogba (1440: иo. I. 175. sz.), ellentmondott egy botosmacskási (DO) iktatásnak (1447: DL 27477). Bádoki familiárisait említik 1441-ben (KmJkv I. 305. sz.). Ügyvéd (1444, 1448: uo. I. 526, 632. sz.). 40

- Balázs, B-Szolnok és Doboka vm. alisp. (1452), B-Szolnok vm. isp. (1455), Doboka vm. isp. (1456). Foris, Kelemen és Lozsádi Albertné Ilona apja (1494: KmJkv II. 2906. sz.). Bádokon birtokos (1494: DL 27223). Ügyvéd (1469: KmJkv I. 1890. sz.), királyi ember (1456, 1472, 1481: DL 27482, 27513, 27214, 36832). 27, 40-41

- János, Doboka vm. szolgabírája (1406-1407). Péter, László, Lukács és Jakab apja ([1430?]: KmJkv I. 40. sz.). Ellentmondott egy botosmacskási (DO) iktatásnak (1447: DL 27477). Királyi ember (1395: ArhIstRom 2/2004. 2. sz. 23. = DL 27441; 1396: иo. 26. = DL 27441). Ügyvéd (1441, 1442, 1447: KmJkv I. 305, 406, 432, 454, 633. sz.). 1441-ben Bádokon lakó familiárisait említik (DO, uo. I. 305. sz.). 36
- László, Doboka vm. szolgabírája (1407). Neve valószínűleg elírás $\rightarrow$ Bádoki János helyett, aki dobokai szolgabíró 1406-1407-ben. 36

- László, Doboka vm. szolgabírája (1435-1436), Doboka vm. isp. (1444), Kolozs vm. isp. (1445). Királynéi ember (1440: DL 30312). Somkeréki [Erdélyi] Miklós végrendelkezésénél tanú (1427: TelOkl I. 505). 39

- Mihály, Doboka vm. isp./alisp. (1475-1476). $\rightarrow$ Antal fia (1473: KmJkv I. 2088. sz.), sólyomkői Menyhárt Mátyásné Julianna (1500, 1502: uo. II. 3133, 3262. sz.) és bádoki Bojti/Vámos Máténé Márta apja (1500, 1502: uo. II. 3133, 3262. sz.). Girolton, Szentmártonmacskáson (DO; 1480, 1486: uo. I. 2294, II. 2628. sz.) és Bádokon birtokos, itt kúriája is volt (1498: uo. II. 3043. sz.; Entz 230; DL 97543). Országbírói és vajdai kiküldött (1481, 1496, 1499, 1500: DL 27541, 27568, 27576. és 27578). 42-43

- Péter, Doboka vm. szolgabírája (1332-1341). Vajdai ember (1348: CDTrans III. 470. sz.), Miklós és János apja (1368, 1369: DRH. C. XIII. 654; BánfOkl I. 289). Vö. LtKözl 55/1984. 2. sz. 130.33

Bagdi (BI; Csánki V. 602)

- (d) Demeter, Kolozs vm. alisp. (1416). 71

Bagói (FH; Iczkovits 38, 50-51)

- Miske, Fehér vm. szolgabírája (1435). A bagói Miske család (Csánki V. 557) tagja. 52

bakaji cs: Macskási

Baksa (Boxa, csomafáji, DO)

- János, Doboka vm. alispánja (1528). 46.

Baládfi cs (KK; Szalók nb.; Csánki V. 843, 906-908; Karácsonyi: Nemzetségek 962-965) 
Balad, Küküllő vm. szolgabírája (1361); a Baládfi család névadója. Balad magister kendhidai Simon bán fia: Tamás fia (1358: CDTrans III. 1011. sz.). Kendhidai Balad, aki Pipe és Istvánd (KK) jószágokban birtokos (1344: uo. III. 192. sz.); kendhidai Balad, Gyákoson birtokos (1373: DRH. C. XIV. 335-337); Zala vm.-ben birtokos (1380: Ub II. 512-513); kendhidai (1383: DL 30726, idézi: Engel: Gen., Szalók nem, 2. tábla: erdélyi ág). Domokos apja (1416: ThLt 25. sz.). 81

Balátfi, Barátfi (Balatffy, Barthffy) András, Hunyad vm. isp. (1531). Egregius, I. János kir. familiárisa (1531: Pataki: Hunedoara 259-260). L. még Barátfi. 64

Balai (kisdevecseri, DO; Kádár-Tagányi III. 292)

- Mihály, Doboka vm. szolgabírája (1495-1496). Kisdevecseren (DO) birtokos (1499: KmJkv II. 3075. sz.). Alvajdai (1498: WassLt 496. sz.; 1499: DL 27577) és vajdai (1500: DL 27231, 28662) ember. A család Feldevecseren is birtokos (1468: DL 62892). 44

Balázsfalvi (FH; Iczkovits 17-18)

- László (Balázs fia), Fehér vm. szolgabírája (1348). Királyi ember (1346, 1357: CDTrans III. 340, 903. sz.), Tür és Kapus/Gyáktelke (FH), Mártontelkén (Selykszék) birtokos (uo. III. 575, 588, 1100. sz.). Famulusát említik (1357: uo. III. 891. sz.). 51

balázsfalvi cs: Cserényi

Bálint, dévai pap, téves közlés szerint Hunyad vm. allevéltárosa [!] (vicearchivarius, 1533: HunyadmÉvk 5/18871888. 108-109). Helyesen: hunyadi esperes (vicearhidiaconus comitatus Hwnyadiensis, 1533. VI. 22., dom., X. mil. mart., MOL, Hunyad megyei családok, R 391, 1. csomó, 8. tétel, $4^{\mathrm{r}}$, Hosdát, Sólyom Fekete gyüjt.-ből).
Balog (alpestesi, HD; Csánki V. 153)

- Ferenc provisor, Hunyad vm. isp., Hunyad vár várnagya (1507). 60

Balog (ispánlaki, FH)

- Pál, Fehér vm. szolgabírája (1511, 1522). István fia (1509: DL 30976). Királyi (1516: DL 26533) és vajdai ember (1516: KmJkv II. 3597. sz.). 53

Balog nemzetség; balogi cs: Derencsényi

Balogsemjén nemzetség: Kállói

Báncsa, Bancha (frátai, KL; Csánki V. 442, Boncza név alatt; Boncz, Boncza, DL 26901, KmJkv I. 2409. sz.)

- Imre, Kolozs vm. szolgabírája (1462). Felesége: Keresztúri Mátyás leánya: Ilona (DO, 1468: KmJkv I. 1833. sz.). Antal, Miklós és hosdáti Porkoláb Balázsné Dorottya apja (1479, 1482, 1509: DL 26806; KmJkv I. 817, 3491. sz.). A család Magyar- és Oláhfrátán birtokos (KL, 1492: DL 26933). Királyi ember (1470: DL 26901). Fogott bíró (1482: KmJkv: I. 2337. sz.). 76

Bánk (Bács vm.)

- Pál, Doboka vm. isp. (1548), Újbálványos (Szamosújvár) várnagya (1540-1549; Kádár-Tagányi VI. 249; EMOkl 559. sz.; KmJkv II. 4934. sz.; Berger: Regesten I. 1512, 1551, 1936. sz.), erd. alvajda és székely alisp. (1553; KmJkv II. 5218. sz.). Egregius (1549; uo. II. 4934. sz.). A szamosújvári építkezések az ő irányításával folytak az 1540-ből való építési emléktáblája szerint (Balogh J.: Az erdélyi renaissance. Kvár 1943. 283-284; uő: Kolozsvári kőfaragó mühelyek. XVI. század. Bp. 1985. p. 332, 383. és 195. sz. kép). 47

Barancskai/Branyicskai (HD; Csánki V. 72-73)

- Tamás, Fehér vm. alisp. (1478-1479). Branyicskán (HD) birtokos. 52 
Barátfi (Barthffy) András, Hunyad vm. isp., Hunyad vár várnagya (1531) 1. Balátfi

Barcsai ([mezőszengyeli, TD; kisbarcsai, HD]; Csánki V. 196; Iványi B.: Barcsai Pál címereslevele. In: Turul 48/1934. 25). Lásd még Kisbarcsai cs.

- Pál magister, egregius, Torda vm. isp. (1525-1526), Hunyad vm. isp. (1531). Dévai Pál (1506: DL 29914), Kisbarcsai Pál (1509: DL 27593; 1510: DL 29615; 1509: iktári Bethlen lt, DF 255080) és barcsai Dévai Pál (1509: DL 27591) néven említik. Anyja Kisbarcsai Vince leánya: Anna (1509: iktári Bethlen lt, DF 255080). A kolozsmonostori konvent jegyzője (1485-1496, vö. KmJkv I. p. 65, 101, 126. II. 2544. sz.; DL 27075, 26938, 28877). Később az országbírói kancellária nótáriusa (1497?-1507, 1510-1516, vö. 1506: DL 29914; 1509 e.-re: DL 27591); a vajdai kancellária secretariusa (1507-1510; 1508: KmJkv I. 3470. sz.; 1509: DL 27591, TelOkl II. 312, DL 27593; 1510: TTár 1907. 106) Szentgyörgyi Péter országbíró és vajda ítélőmesterének, Werbőczi Istvánnak a keze alatt. Ezalatt II. Ulászló királytól Árkin (HD, 1506: DL 29914) és Kisbarcsán (más néven Apródpálfalván, HD, 1510: DL 29615) kap jószágrészt. Szapolyai János vajda ítélőmestere 1516-től (1516: a vajdai kancellária alkalmazottja, WassLt 622. sz.; protonotarius, 1519: KmJkv II. 3708. sz.; iktári Bethlen cs lt, DF 255097; 1527: uo. VI. R. Fasc. 327. no. 2). 1527-ben a Habsburg-pártiak bebörtönzik, majd 1528-ban követi Szapolyait Lengyelországba (1531: iktári Bethlen cs lt, VI. R. Fasc. 20. no. 6; ENMLt, Kemény J.: Diplomatarii Transsilvanici Supplementum. VI. 171-176). Visszatérésük után királyi secretarius Budán és Hunyad vm. isp. (1531: iktári Bethlen cs lt, VI. R.
Fasc. 20. no. 12; ENMLt, Kemény J.: i. m. VI. 171-176), erdélyi ítélőmester (1531: iktári Bethlen cs lt, VI. R. Fasc. 20. no. 12). Kisbarcsán birtokos (HD 1509: iktári Bethlen cs lt, DF 255080) Mezőszengyelen és Mezőszakálon jószágrészt szerez (TD, 1516: iktári Bethlen cs lt, DF 255093-255094; vö. 1536: KmJkv II. 4569. sz.), Korpádon jószágrészt kap zálogba, amit utóbb továbbad (KL, 1493, 1495: uo.: II. 2899, 2974, 3774. sz.). Birtokszerzeményeit megerősítteti a vajdával (1526: iktári Bethlen cs 1t, VI. R. Fasc. 304. no. 34). + 1532 e. (Kemény J.: i. m. VI. 203-206; a felsorolt adatok forrása Jakó Zs.: Az erdélyi vajdai kancellária szervezete a XVI. század elején. In: EM 52/1947. 70-73, ill. uő: Írás, könyv, értelmiség. Bukarest 1976. 53-56). 63, 89

Basu, curialis comes, Kolozs vm. (1214). 65

Becsegergely nemzetség: Apafi, Bethlen, Erdélyi

Bécsei (tévesen Bechey: WassLt 442. sz.) Gergely, Doboka vm. szolgabírája (1450-1452) 1. Récsei Gergely

Beken, curialis comes, Kolozs vm. (1213). 65

Bekes (Bekws, [endrédi, vö. DL 37797], AD; Csánki II. 73)

- János, Hunyad vm. isp., Hunyad vár várnagya (1509, 1520-1529). Hunyad vár birtokosának, Brandenburgi Györgynek a familiárisa (Pataki: Hunedoara 177); Facsáti (Krassó vm.); egregius; Gyula (Békés vm.) várnagya (1524, 1528: Veress: GyulaOklt 83, 85, 136). 61

Béldi (FH; Iczkovits 51)

- Benedek, Fehér vm. szolgabírája (1494). Márton apja, Bodolán (FH) birtokos (1462: DL 45028). 1467-ben az erd. kápt. szilvási, 1498-ban pedig orbói (FH) birtokát pusztítja (1467: 
KmLt 210, 303. sz. $=$ DF 275368). Vajdai ember (1492, 1493, 1506, 1513, 1520: DL 30481, 30931, 26491, 30534, 31030). 53

béldi cs: Herepei

[Bencefi] (v. Pestesi, HD; Csánki V. 163)

- Mihály (Benche fia) Hunyad vm. szolgabírája (1395). 56

bencenci cs: Aranyi

Benedek comes, László erd. alvajda helyettese [Fehér vm. isp.?] (1291: CDTrans I. 479. sz.). 49

- (Lőrinc fia), Doboka vm. szolgabírája (1350). 33

- Doboka vm. isp. (1443). 39

Benkovics (Benkowyth, plávnai, BCs; Csánki II. 158)

- Miklós (Nicolaus de Plawna), Hunyad vm. isp., Hunyad vár várnagya (1506). 1507 k. állítólag adományul kapta Corvin János herceg özvegyétől [Frangepán] Beatrixtől Kávás, Fajdas, Somos, Újfalu (ZD) birtokokat (1507: DL 37812). 60

bényei cs: Herepei

Bereck várnagy, Kolozs vm. isp. (1462). Talán azonos „Porkoláb” Bereckkel, aki Torda vm. isp. (1462-1463). 76

Berecki (harói, HD; Csánki V. 163)

- Péter, Hunyad vm. szolgabírája (1520-1536). 62, 64

Besenyő ([galántai /PO/? vagy özdögei /Ny/?]. Azonosítására lásd Engel: Arch. I. 246, 295. II. 35.)

- Pál, B-Szolnok vm. isp. (1368). Csicsói várnagy (1364: TelOkl I. 133; [1364-1368]: DocVal 178). 25

Bethlen ([bethleni], BSz; Becsegergely nb.; Csánki V. 438; Engel: Gen., Becsegergely nem, 3. tábla: Betleni, Bethlen)

- Gergely (Jakab fia: János fia, lásd Engel: Arch. I. 249), magister, Kolozs vm. isp. (1373). Szatmári alisp. (1370), ud- vari lovag (1390-1393, Engel: Arch. II. 36). Bethlen, Málom (BSz, 1368, 1369: DRH. C. XIII. 541, 635), Bőd (BSz) birtokosa (1371: Ub II. 757). Rokonaival együtt visszaadja a virágosberkieknek Brétét és Szekérbrétét (1364: TelOkl I. 132-135). Részt vett Zsigmond kir. havasalföldi hadjáratában, személyes küldötte (1395: ZsOkl I. 3913. sz.). 69

Bikali (bikali, tamásfalvi, középlaki, KL; Csánki V. 438-439)

- Ambrus, Kolozs vm. szolgabírája (1524). Inaktelki Gyerőfi András leánya: Erzsébet férje (1543: KmJkv II. 4805. sz.). 1526-ban Bikal, Alsó-, Közép- és Felsőfüld, Tamásfalva, Topa, Szentmihálytelke (KL) birtokokból követelt részt (1526: uo. II. 4164. sz.; vö. 1518 u.: uo. II. 3699. sz.), Valkón (KL) birtokos (1542: иo. II. 4763. sz.). Bikali (1538: uo. II. 4647. sz.). † 1545 e. (uo. II. 4858. sz.). 79

bikali cs: Bikli

Bikli ([bikali], KL; Csánki V. 48-49, 439; Engel: Gen., Mikola rokonsága, 8. tábla: Bikali, Tamásfalvi)

- János, Hunyad vm. isp., Hunyad vár várnagya (1494-1495, 1496-1498, 1500-1504). Felesége: harinai Farkas Tamás leánya: Margit (1510: KmJkv II. 3556. sz.), gyermekeik: Tamás, Ferenc, János, Katalin, Margit, Borbála és Erzsébet (1522: uo. II. 3867. sz.). Egregius (1516: uo. II. 3607. sz.). Hunyad várát (HD) zálogban bírta. Felesége testvérével ennek Doboka, B-Szolnok, Torda és Kolozs vm.-i birtokait illetően örökösödési szerződést kötött; Biklinek ekkor Kolozs és B-Szolnok vm.ben voltak birtokai (1502: uo. II. 3607. sz.; vö. 1505: uo. II. 3375. sz.). Bikali (KL; uo. II. 3261. sz., említve birtokai). Corvin János familiárisa (1499: DL 30493); amikor Mátyás Hunyad vá- 
rát Nagylucsei Orbán egri püspökre bízta (1489-1491), ez utóbbi állítólag Biklit elfogatta (Jajcza 85; DL 37673, idézi Kubinyi A.: A megyésispánok 1490-ben és Corvin János trónörökösödésének problémái. In: A Veszprém megyei múzeumok közleményei 16/1982. 179. 109. jegyz.; uő: A budai vár udvarbírói hivatala, 1458-1541. In: LtKözl 35/1964. 87). Familiárisát említik 1519-ben (KmJkv II. 3739. sz.). Fogott bíró (1504, 1507: TelOkl II. 265, 298). $59-60$

Bíró (HD)

- (hosdáti, HD; Csánki V. 170) Bálint, Hunyad vm. szolgabírája (1495-1496, 1505, 1507-1508). 59-61

- (pestesi, HD; Csánki V. 164) Máté, Hunyad vm. szolgabírája (1489). 58

Bíró László, Torda vm. isp./alisp. (1446, 1448) 1. Hadrévi „Bíró” László

Boda (kistárkányi, ZN; Engel: Gen., Boda, kistárkányi)

- Dénes, B-Szolnok vm. isp. (1443). Kistárkányi Miklós deák fia (1414, 1418: ZsOkl IV. 2715. sZ., VI. 1806. sz.). Akolszögön (ZN) birtokos (1437: Szerbia 108). Hunyadi János erd. vajda familiárisa; Brankovics György rác despota Pácin és Karsa birtokokat adományozza neki (ZN, 1443: Szerbia 142-143); címeres pecsétje magánlevelén: 1443, KárOkl II. 232-233. (A felsorolt forrásokat idézi: Engel: Gen.). 27

Bogár (Bugar d) János, Kolozs vm. szolgabírája (1351) 1. Korpádi János

Bogáti (bogáti, TD; Csánki V. 749-753; Engel: Gen., Kökényesradnót nem, 2. tábla: Bogáti)

- „Herceg” (d) Péter, Torda vm. szolgabírája (1366). [Dobokai] Mikud bán fia: Péter comes fia: Herchek (d) Péter; Bányabükkön (TD; 1355: CDTrans III. 775. sz.) és Mikesen (1352: uo. III. 674. sz.) birtokos. Magister (uo. III. 908. sz.). Fia: $\rightarrow$ Imre. 86

- Imre, Küküllő vm. isp. (1416). „Veres” (Rufus) Imre, $\rightarrow$ „Herceg” Péter fia (1389: ZsOkl I. 950. sz.; 1391: Ub III. 22). Feleségei: Gerendi Miklós leánya: Margit (1411: ZsOkl III. 191. sz.; 1416: uo. V. 1739. sz.), majd Járai Mihály fia: László leánya (1438: KmJkv I. 99. sz.). Gyermekei: László (1391: Ub III. 22), Péter (1435, 1438, 1439: uo. IV. 572; KmJkv I. 99. sz.; DL 28379), Drági Jakabné Brigitta (1422: TelOkl I. 459) és vingárti Geréb Miklósné Otília (1438: Ub V. 11, lásd Engel: Gen.). A Küküllő vm.-i Bolkácson, Zsidvén (1391: ZsOkl I. 1977. sz. = Ub III. 22), Ádámoson (1405: ZsOkl II/1. 4276. sz.), Dégen (1419: uo. VII. 818. sz.), a Fehér vm.-i Szentjakabon és Oroszin (1410: uo. II/2. 7547. sz.) és Kolozs vm.-ben birtokos (1409: uo. II/2. 7225. sz.). 1423-ban a havasalföldi törökellenes hadjáratba készülve radnóti (KK) birtokának jövedelméből adományt tesz a radnóti templom javára (1423: KmLt 113. sz. = ZsOkl X. 907. sz.). 82

Bojtori (HD; Csánki V. 165)

- (de Boythor) György, Hunyad vm. alisp. (1496). Vajdai ember Hunyad vm.-ben (1482: DL 29855). 59

Bolyai (FH)

- Dávid, Fehér vm. kapitánya (1525). 54

Boncnyíresi 1. Nyíresi

Bonca, Boncza (frátai) 1. Báncsa

Bongárdi (DO; Csánki V. 442)

- János, Doboka vm. szolgabírája (1332). Bongárdon (DO) birtokos (1343, 1344: CDTrans III. 153, 161, 197. sz.). 33

- Mihály, Doboka vm. szolgabírája (1378). Királyi ember (1377: DRH. C. XV. 211). 34 
bongárdi cs: Szilágyi

Bordi (széplaki, kisfaludi, radnóti, KK; Csánki V. 917) cs

- (Radnóti) Bord (d) László, Küküllő vm. szolgabírája (1407). Valószínüleg azonos azzal a Bordi Lászlóval, aki 1395-ben Kolozs vm.-ben jár el vajdai emberként a Tuzsoniak birtokügyében (1395: TelOkl I. 250). További említések: 1383, 1390, 1407, 1420: DL 30137, 31111, 30411; ZsOkl VII. 2101. sz. 81

- Bord/Burd, Küküllő vm. szolgabírája (1344). Vajdai közgyülésen ülnök (Bord, 1344: CDTrans III. 227. sz.), vajdai ember (1351: uo. III. 589. sz.). Bord faluban (KK) birtokos (1337: uo. II. 927. sz.). 81

Borsa nemzetség: Gyulai, Iklódi, Nadányi, Szentpáli

borzafői cs: Huszár

Bot

- Miklós, B-Szolnok vm. alisp. (1482). 28

Botházi (KL; Csánki V. 443)

- Péter, Kolozs vm. szolgabírája (1516-1517). Botházán (KL) birtokos (1515: KmJkv II. 3591. sz.; TelOkl II. 345). Felesége: Katalin (1535: KmJkv II. 4542. sz.). 1536-ban néhai (uo. II. 4575. sz.). 79

botházi cs: Porkoláb

Bozkúti (Bwzkuthy; KL; Csánki V. 338; Bozkút elnéptelenedett település Mócs környékén)

- János, Kolozs vm. alisp. (1482). 77

Brassói-rokonság: Drági

Budai ([budai, óbudai], KL; Buda = Burjánosóbuda, Bodonkút; Csánki V. 446-451). Lásd még Budai (sárdi), Kis (újbudai) cs.

- Gergely, Kolozs vm. szolgabírája (1419). György fia, Buda, Diós, Kölesmező és Balogjánostelke (KL) bir- tokokban voltak jószágrészei (1407: ZsOkl II/2. 5265, 5551. sz.). Királyi kiküldött (1417, 1421: uo. VI. 20. sz.; uo. VIII. 1238. sz.). 72

- György, Kolozs vm. szolgabírája (1363). Mihály fia, Budán és Kölesmezőn (KL) birtokos (1367: DRH. C. XIII. 445). Alvajdai ember (1360, 1364: uo. XI. 534; XII. 249, 287). 68

- Lázár, Kolozs vm. alisp. (1497). $\rightarrow$ Pál fia (1486: KmJkv II. 2607. sz.). Jószágrészei vannak a következő birtokokban: Buda, Kölesmező és Diós (KL, 1502: uo. II. 3237. sz.); Nádason (KL) jószágrészt vesz zálogba (1510: uo. II. 3551. sz.). Felesége: Szentpáli Tamás leánya: Katalin (KL, 1502: uo. II. 3237. sz.). Fia: György és Pál (1518, 1536: uo. II. 3659, 4557. sz.). 1518-ban néhai (uo. II. 3682. sz.). 78

- Pál, Kolozs vm. szolgabírája (1482). Óbudai Pál (1498: KmJkv II. 3049. sz.). $\rightarrow$ Lázár, Imre, Barnabás és Ambrus apja, Óbudán és Dióson (KL) birtokos (1486: uo. II. 2590. sz.). 77

Budai (sárdi, KL; Csánki V. 446-452). Lásd még Budai (budai, óbudai) cs.

- Gergely, Kolozs vm. isp. (1522-1526). $\rightarrow$ István fia (1499, 1519: KmJkv II. 3101, 3751. sz.). Felesége: Gesztrágyi Albert leánya: Margit (1517: uo. II. 3638. sz.), gyermekei: nádasdi Tomori Györgyné Klára, István, Eustachius (1526, 1543: uo. II. 4133, 4783. sz.). Egregius (1524: DF 257632). Sárdi Budai „Nagy” Gergely, nándorfehérvári vicebán 1514-ben (1514: RevArh 4/1998. 1-2. sz. 104-105. = KolozsNLt, Kolozsvári ferences rendház lt, DF 292763; 1517, 1519: KmJkv II. 3638, 3715. sz.; Monumenta Hungariae Historica. 2. Scriptores. III. köt. Pest 1857. p. 8, 1. sz. jegyzet). Birtokai Kolozs vm.-ben feküdtek: Sárdon (1497, 1521-1522: KmJkv II. 3016, 3830, 3871. sz.), Szent- 
mihálytelkén (1519: uo. II. 3751. sz.), Magyarnádason (1517, 1520, 1524: uo. II. 3638, 3755, 3987. sz.), Kölesmezőn, Óbudán (1520-1529: uo. II. 3766, 4032, 4182, 4264. sz.), Gyekén (1526: uo. II. 4133-4134. sz.), zálogba vett Szomordokon (1524: uo. II. 4005. sz.), Kölesmezőn (1525: иo. II. 4070. sz.), Berenden (1526: uo. II. 4141. sz.); [Kalota]szentkirályon, Deritén, Oláhbikalon és Bedecsen (1527: uo. II. 4202. sz.) pedig vásárolt jószágrészeket. Szapolyai János erd. vajda familiárisaként [1521-ben?] részt vett ennek havasalföldi hadjáratában ([1529?]: uo. II. 4268. sz.). 1543-ban néhai (uo. II. 4783. sz.). 79

- István, Kolozs vm. szolgabírája (1492-1493). Sárdi $\rightarrow$ Budai Gergely és $\rightarrow$ Vince apja $(1499,1519:$ KmJkv II. 3101, 3751. sz.). Fogott bíró (1493: uo. II. 2872. sz.). Néhai 1499-ben (uo. II. 3101. sz.). 77

- Vince, Kolozs vm. szolgabírája (1513-1514, 1521-1522). $\rightarrow$ Sárdi Budai István fia, $\rightarrow$ Gergely öccse (1499, 1519: KmJkv II. 3101, 3751. sz.). Sárdon és Újbudán (KL) birtokos, ahol kúriái voltak (1500, 1505: uo. II. 3129, 3365. sz.). 78-79

Burd, Küküllő vm. szolgabírája (1344) 1. Bordi.

Burján (péterfalvi, petendi, KK; Csánki V. 918; Péterfalva = Magyarpéterfalva; Petend vagy Pettend = elnéptelenedett település Szancsal környékén)

- Pál, Küküllő vm. szolgabírája (1448). Alvajdai, kormányzói, királyi kiküldött $(1437,1438,1447,1448,1453$ : DL 29783, 27648, 29791, 14196, 27667). Szancsalon (KK) jószágrészt vesz zálogba (1438: DL 29785; vö. 1440: ThLt 28. sz.); péterfalvi; királyi ember
(Bánffy cs nemz. lt, 1435: DF 260739). 82

- [---], Küküllő vm. szolgabírája (1439).

Lehet, hogy a fentivel azonos. 82

Bükkösi (KK; Csánki V. 870, Bikkesi név alatt)

- János (Boncha fia), Küküllő vm. szolgabírája (1416). 82

Bwzkuthy 1. Bozkúti

Caplon/Coplon, Doboka vm. szolgabírája (1331) 1. Lónai Caplon

Cibak ([palotai, gyéresi, BI]; Csánki I. 631-632; Engel: Gen., Hontpázmány nem 10. Szentjánosi ág, 2. tábla: Cibak; Palota = elnéptelenedett település Újpalota közelében; Gyéres = Körösgyéres).

- László, Kolozs vm. isp. (1429-1430). Palotai (BI) Chybak fia: Mihály fia: László magister fia; testvérei: Mihály, János és György (1403: ZsOkl II/1. 2434. sz., vö. uo. VI. 1436. sz.). Palotai Chybak, Mihály és László apja (1417: ZsOkl VI. 1183. sz.). Családja: szöregi (CsD; 1411: Reizner János: Szeged története. IV. Szeged 1900. 19. = ZsOkl III. 622. sz.); Apátin birtokos (ZD, 1415: $\mathrm{ZsOkl} \mathrm{V.} \mathrm{1300.} \mathrm{sz.;} \mathrm{a} \mathrm{forrásokat} \mathrm{idézi}$ Engel: Gen.). 73

Cikmántori (KK, Szalók nb.; Csánki V. 843, 920; Engel: Gen., Szalók nem, 2. tábla: erdélyi ág)

- János (Jakab fia), Küküllő vm. szolgabírája (1407). 81

Cine (Cyne, olaszi, de Olazy; BI; Olaszi $=$ Érolaszi)

- Marót (Marouth) magister (Olaszi Cyne /d/ Péter fia; $\mathrm{BH})$, Torda vm. isp. (1350). 85

Corvin János, Hunyad vm. isp. (14791504?). Vajdahunyad vár birtokosaként viseli olykor az ispáni címet, ez idő alatt a várnagyok familiárisai közül kerülnek ki. 57, 60 
Cucor (Cuchor, gáldi, FH)

- Balázs, Fehér vm. alisp. (1510). 53

Csanádfi (pestesi, HD; Csánki V. 168)

- Bertalan (= alpestesi Csanád Bertalan), Hunyad vm. szolgabírája (1467-1469). 57

- Fábián (= alpestesi Csanád /d/ Fábián), Hunyad vm. szolgabírája (1433-1439). 56

- István ([István?] fia), Hunyad vm. szolgabírája (1413). 56

- István, Hunyad vm. szolgabírája (1390-1395). Alpestesi; Csanád fia; alvajdai ember (1389: DocVal 358). 56

Csák nb.-i Pós (Pous), Csák nb.-i (Engel: Gen., Csák nem 8., Újlaki ág; Karácsonyi: Nemzetségek 319, 360), Fehér vm. isp. (1227), Béla szlavóniai, majd erdélyi hercegi tárnokmestere (1227-1233). További tisztségei: Bács vm. isp. (1225, 1235), szörényi bán (1235), kir. tárnokmester (1235). Lásd Zsoldos: Archontológia 49, 61, 74, 127, 151, 347; Kristó Gy.: Kán László és Erdély. Tanulmányok az Árpád-korról. Bp. 1986. 272-274. 49

Csáni ([mezőcsáni], TD; Csánki V. 756758)

- János (Torda fia), Torda vm. szolgabírája (1392). Torda fia, $\rightarrow$ Mihály apja (1413: ZsOkl IV. 335. sz.). 86

- László (mezőcsáni; Thorda fia; [= „Tordafi"]), Torda vm. alisp. (1449). Torda fia; Jára, Túr, Csán (TD) falvakban birtokos (1430 [?], 1441: KmJkv I. 57, 381. sz.), Szentjakabon (TD) jószágrészt vesz zálogba (1446, 1452 [?]: uo. I. 600, 1029. sz.). Ügyvéd (1439: uo. I. 165. sz.), fogott bíró (1442 [?]: uo. I. 403. sz.), vajdai ember (1447: uo. I. 606. sz.). Benedek apja (1443: uo. I. 477. sz.). Özvegye: Iklódi Erzsébet (1452 [?]: uo. I. 1057. sz.). 88
- László, Torda vm. szolgabírája (1461). István fia (1461: KmJkv I. 1618. sz.). Ügyvéd (1466: uo. I. 1685. sz.). 88

- Mihály (János fia), Torda vm. szolgabírája (1421). Torda fia: $\rightarrow$ János fia, Szentjakabon (TD) birtokos (1413: ZsOkl IV. 335. sz.). Alvajdai ember (1415: uo. V. 355. sz.). „Torda” Mihály, Skolasztika férje (1429: DL 28809). 86

Császári (Cassari, Chasary d, egresi, [szentmártoni]; TD; Csánki V. 758759)

- Mihály, Torda vm. szolgabírája (1444), Torda vm. alisp. (1449). Felesége: Egresi Balázs leánya: Skolasztika, gyermekei: Albert, Mihály, Zsigmond, Borbála, Lúcia és Margit (1444, 1449, 1467: KmJkv I. 516, 772, 1762. sz.). Azonos szentmártoni Császár Mihállyal, aki alsóegresi (TD) birtokok eladományozása ellen tiltakozik (1440: uo. I. 250. sz.). Ez utóbbi néven említve, ügyvéd (1442, 1461: uo. I. 469, 1649. sz.). Felesége révén birtokos Egresen (TD, 1444: uo. I. 516). Szentmártoni (TD) jószágrészt vesz zálogba (1455: uo. I. 1216. sz.). 1467-ben néhai (uo. I. 1762. sz.). $87-88$

Császár (szentgyörgyi, HD; Csánki V. 137, 168; Szentgyörgy = elnéptelenedett település Dédács környékén)

- Demeter, Hunyad vm. szolgabírája (1489-1494). Királyi és vajdai ember (1498, 1499, 1501, 1504: DL 29889, 29546, 28887; Pesty: Krassó 477). Piski (HD) szomszédja (1498: DL 28881). 59

Csegedi (Chegedy, szentgyörgyi, TD; Csánki V. 760; Szentgyörgy = Csapószentgyörgy)

- Gergely, Torda vm. szolgabírája (1485-1487, 1493-1494). 89

Cseh $(d)$ [DO?] 
- János, Doboka vm. szolgabírája (1334). Valószínütlen, hogy a Kolozs vm.-ben birtokos rödi Cseh cs tagja lenne. 33

Cseh (rődi, KL; Csánki V. 453-456)

- (Chech d) Dezső (Jakab fia), Kolozs vm. szolgabírája (1349). Rőd és Galac, ill. Pata és Bós részbirtokosa (KL, 1345, 1346: CDTrans III. 306, 320. sz.). 67

- Gergely, Kolozs vm. szolgabírája (1499). Bálint fia: György fia (1486, 1497: KmJkv II. 2575, 3020. sz.). Mátyás, Gábor, Ferenc és Zsófia apja (1504: uo. II. 3302. sz.). Szentmárton, Rőd (TD) és Gyéres (KL) birtokokban van része $(1486,1497,1501$ : uo. II. 2575, 3020, 3200, 3269. sz.); szentmártoni jószágrészéről lemond Szentgyörgyi Péter erd. vajda javára (1509: uo. II. 3526. sz.); királyi kiküldött (1497: TelOkl II. 219). 78

- Jakab, Kolozs vm. isp. (1312-1314). Kán nb. László erd. vajda familiárisa (1312: CDTrans II. 195. sz.). 1336-ban néhai; Péter rődi (hibásan: Beud-i) nemes apja (1336: uo. II. 907. sz.). 66, 68

- László, Kolozs vm. szolgabírája (1353-1355). Rődi Cseh Jakab fia (1345, 1346: CDTrans III. 306, 320. sz.). Alvajdai, vajdai ember (1351, 1366: uo. III. 628. sz.; BánfOkl I. 267). Pecsétjének leírása: TelOkl I. 97. 68

- Mihály comes, Kolozs vm. szolgabírája (1334 [?], 1340 [?]). Rődi Cseh Jakab fia (1345: CDTrans III. 295, 306. sz.). Jakab apja (1358: иo. III. 983. sz.). 67

- Miklós, Torda vm. isp. (1444-1446). $\rightarrow$ Péter apja $(1460,1485:$ KmJkv I. 1492, II. 2508. sz.). Létai (TD) officiális (1450: uo. I. 916. sz.). 1431 k. a kir. szolgálatában volt (uo. I. 66. sz.). Ügyvéd (1439, 1452: uo. I. 137, 1024. sz.), fogott bíró (1445, 1450: uo. I. 542, 835. sz.). 1461-ben néhai (uo. I. 1615. sz.). 87
- Péter, Kolozs vm. szolgabírája (1493). $\rightarrow$ Miklós fia (1460, 1485: KmJkv I. 1492, II. 2508. sz.). Özvegye: Dorotytya, Porkoláb Balázsné; gyermekei: Imre pap, Miklós, Pál és Apollónia (1509: uo. II. 3506. sz.). Budaki (DO) jószágrész birtokosa (1472, 1485: uo. I. 2057, II. 2508. sz.). Örökös birtokrészei voltak Szentjakabon (TD, 1493: uo. II. 2874. sz.), Patán (1468: uo. I. 1876. sz.), Bóson (1473: uo. I. 2106. sz.) és Rődön (KL, 1503: uo. II. 3290. sz.). Királyi kiküldött (1497: TelOkl II. 219). 1509-ben néhai (uo. II. 3506. sz.). 77

\section{csehi cs: Móré, Nádasi}

\section{Csekelaki (FH; Iczkovits 52-53)}

- Adorján, Fehér vm. szolgabírája (1455). Ügyvéd (1468: KmJkv I. 1826. sz.). Csekelakán (FH) kúriája volt (1486: uo. II. 2569. sz.). 1481-ben néhai (uo. I. 2332. sz.). 52

- Miklós (Lukács fia), Fehér vm. szolgabírája (1336). Vajdai ember (1331, 1339: CDTrans II. 703, 1020, 1031. sz.). 50

Csép (Cheph d) János, Doboka vm. szolgabírája (1331). 33

Cserényi (Chereny, [balázsfalvi], DO; Csánki V. 456)

- Pál, Kolozs vm. isp. (1493). Drágfi Bertalan erd. vajda (1493-1497) familiárisa, törcsvári várnagy (1494: TTár 1907. 104. = DF 244554). Balázsfalvi, 1519-ben familiárisát említik (KmJkv II. 3736. sz.). Alsó- és Középfüldön (KL, 1504: uo. II. 3319. sz.), Kisesküllőn (DO, 1505: uo. II. 3364. sz.), Járán (TD, 1508: uo. II. 3462. sz.), Szentandráson, Kajlán (DO, 1510: uo. II. 3540. sz.) jószágrészt vesz zálogba. A losonci Bánffy család osztályánál fogott bíró (1515: uo. II. 3587. sz.). 77

Cseszelicki (Kyzeleczky, keresztesi; TD; Keresztes, ma Torda város része) 
- János, Torda vm. isp. (1499). Szentgyörgyi Péter erd. vajda familiárisa; ispáni kinevezéséről értesítés Torda vm.-hez 1499-ből maradt fenn (DL 65442). Mátyás fia (1516: DF 255093. = Jakó-Manolescu 1987. Kézírások34A). Valószínüleg a Kolozs és Torda vm.ben birtokos [mező]szilvási (KL) Cseszelicki cs (vö. Csánki V. 456-457, 714) tagja. Drágfi Bertalan erd. vajda kérése a kolozsmonostori konventhez, hogy Keresztes egészbirtokba (TD) losonci Dezső fiát: Jánost vezessék be, az iktatásnál pedig Cseszelicki (Chezelezky) János (egregius; aule regie miles) egyik ottani jobbágya - ura nevében - ellentmondott (1495: DL 28452; vö. 1496: DL 28454). 89

csesztvei cs: Csongvai, Mike

Csikós (harói, HD; Csánki V. 168)

- Pál, Hunyad vm. szolgabírája (1500). 60

Csolnokosi (HD; Csánki V. 169)

- [Mihály?], Hunyad vm. szolgabírája (1507). Az oklevélből a szolgabíró keresztneve hiányzik. Valószínűleg azonos azzal a Csolnokosi Mihállyal, aki ekkoriban vajdai ember (1506: Amlacher: Broos 79). 60

\section{Csomafáji (DO)}

- István, Doboka vm. alispánja (1528) és szolgabírája (1530-1538). Gergely fia (1507: KmJkv II. 3429. sz.). János, Ferenc, György, Márta, Margit és Zsófia apja (1507, 1518: uo. II. 3429, 3676. sz.). Csomafáján és Szentmártonmacskáson (DO) birtokos, előbbin kúriája volt (1498, 1509: uo. II. 3047, 3494. sz.). Királyi ember (1514: uo. II. 3585. sz.; BánfOkl II. 446). 46

csomafáji cs: Baksa, Erdélyi, Kidei, Tót csombordi cs: Tompa

Csongvai (csesztvei, FH; Iczkovits 53)
- Gergely, Fehér vm. szolgabírája (1483). 53

- (Chungway) György (csesztvei), Fehér vm. szolgabírája (1510). Nádori ember (1507: DL 30071). 53

Csoronk (Choronk, Chorunk; papfalvi, KL; Csánki V. 458-459, 566; Papfalva = Nádaspapfalva)

- Benedek, Kolozs vm. szolgabírája (1413-1414). Papfalvi Chornuk fia, Papfalván (KL) birtokos (1397: ZsOkl I. 5116. sz.). 1389-ben Kolozs vm. szolgabírái előtt köt egyezséget (TelOkl I. 222). Elfoglalta a kolozsmonostori apátság Bács (KL) nevű birtokát (1411, 1415: ZsOkl III. 1139. sz.; V. 862. sz.). Királyi ember (1415: uo. V. 582. sz.). 71

- Benedek, Kolozs vm. szolgabírája (1514). Papfalván birtokos (1498: KmJkv II. 3053. sz.). Pál fia. Felesége: Markos (d) Mihály kolozsvári polgár leánya: Eufrozina (1508: uo. II. 3453. sz.). 79

Csúcsi (de Chwch, FH; Iczkovits 53)

- Miklós, Torda vm. isp. (1447). Gomboc, Nándorlaka és Bükkös (FH) iktatásakor szomszéd birtokos (1449: KmJkv I. 656. sz.). 87

csúcsi cs: Tomori

Csuka (harói, HD; Csánki V. 170)

- Máté, Hunyad vm. szolgabírája (1495-1496). Királyi kiküldött (1506: DL 29914). 59

- Mátyás, Hunyad vm. szolgabírája (1500). Neve valószínűleg elírás Máté helyett. 60

- Tamás, Hunyad vm. szolgabírája (1477-1479, 1483). 57-58

Csutaki (de Chutak, valószínúleg elírás de Zvchak helyett) Tatár (d) Péter, Kolozs vm. szolgabírája (1415-1417) 1. Tatár $(d)$ Péter

Csügedi (FH; Iczkovits 53) 
- Miklós, Fehér vm. szolgabírája (1435). 52

Dancs (szindi) 1. Tancs

Darabos (macskási) 1. Macskási

Darabos Mihály, B-Szolnok vm. isp. (1397-1400) 1. Andrásházi Darabos Mihály

Darlaci Miklós (KK; Engel: Gen., Szalók nem, 2. tábla: erdélyi ág)

- Miklós, Küküllő vm. szolgabírája (1344). Simon bán fia: Miklós; Véckefőn és Zsákodon (KK) birtokos (1342: CDTrans III. 92. sz.); Darlaci (1344: uo. III. 188. sz.). Magister (1351: uo. III. 617. sz.). 1344-ben a vajdai közgyűlésen ülnök (1344: uo. III. 227. sz.). 81

Deák (litteratus) Bálint, Kolozs vm. isp. (1468). 76

Deáki $(B S z ;$ Deáki = elnéptelenedett település, ma puszta Kodor szomszédságában)

- Balázs, B-Szolnok vm. szolgabírája (1449-1455). Ügyvéd (1440, 1459: KmJkv I. 256, 1384. sz.). Tévedés, hogy Kolozs vm. szolgabírája lett volna (Turul 82/2009. 1. sz. 8). 27

- Mihály, B-Szolnok vm. szolgabírája (1474). 28

Dédácsi (HD; Csánki V. 172-173)

- Illés, Hunyad vm. alisp. (1467). Királyi ember (1462: TTár 1907. 113. = DF 244546). 57

Deme (Miklós testvére), Doboka vm. szolgabírája (1305). Talán azzal a Demével azonos, aki Tötörön birtokos (DO, 1317: CDTrans II. 265. sz.). 32

Demjén nemzetség: Lapádi

Dénes, Kolozs vm. szolgabírája (1347). 67

Dengelegi (SzR; Csánki I. 493; Káta nb., Engel: Gen., Káta nem, 5. tábla: Dengelegi Pongrác)
- Zsigmond, Hunyad vm. isp., dévai várnagy (1433). Középszolnok vm. alisp. (1418-1427). Bertalan fia, Dengeleg birtokosa (SzR; 1399: KárOkl I. 504. = ZsOkl I. nr. 6040; 1448: Ub V. 257. = DF 292189). Csáki Miklós és László familiárisa (Engel: Arch. I. 201. II. 59). Királyi ember (1422: ZsOkl IX. 214. sz., az adatok forrása: Engel: Gen.). 56

Dengelegi (BSz; Kádár-Tagányi III. 262)

- (d) István magister, B-Szolnok vm. szolgabírája (1392, 1399). Dengeleg (BSz) birtokosa (1397: TelOkl I. 261). 26

- Zsigmond (Mihály fia), B-Szolnok vm. isp. (1443), Demeter fia: néhai Mihály fia (1443. I. 2.: Beszterce v lt = DF 247260, vö. Berger: Regesten I. 111. sz.). Dengeleg birtokosa (1439: DL 29074), ennek 1439-es eladományozása után az iktatáskor tiltakozik (DL 27873). Királyi ember (1456: BánfOkl I. 688$) .27$

Derencsényi [balogi, derenki, GM; terenyei, NO; Balog nb.; Karácsonyi: Nemzetségek 192; Engel: Gen., Balog nem 2. Derencsényi; Engel: Arch. I. 271. II. 60]

- „Orros" Pető (Péter) erd. alvajda (1337-1342), Fehér vm. isp. (eml.: 1339). Miklós fia (1325: AOkl IX. 584. sz.). Orros (1338: TelOkl I. 56-57; 1344: Hanvay 58. sz.). $\rightarrow$ János, B-Szolnok vm. isp. (1370) és $\rightarrow$ Miklós, Doboka vm. isp. (1364-1372) apja. 50

- János magister ( $\rightarrow$ Pető fia), B-Szolnok vm. isp. (1370). Testvéreivel együtt Léta (KL) várnagya (1364: TelOkl I. 133; Petheu fiai: Miklós, László és János (idézi Engel: Gen.). Bálványos vár (BSz) várnagya (1364-1371: TelOkl I. 133; Ub II. 366). Testvére: $\rightarrow$ Miklós, Doboka vm. isp. (1364-1372). 25 
- Miklós magister ( $\rightarrow$ Pető fia), Doboka vm. isp. (1364-1372). Gömör vm. alisp. (1354-1357; Engel: Arch. I. 130), majd a Lackfiak familiárisaként dobokai ispán (1364-1372), 1364-ben Léta (KL, DRH. C. XII. 292-295), 1364-1371 között Bálványos vár (BSz, TelOkl I. 132-135; Ub II. 366) várnagya, 1377-1380 között székely ispán (Engel: Arch. I. 192). 1373-ban a királyi udvar tagja (DL 48025, idézi Engel: Arch. I. 485). 1380-ban miles, ekkor adományként megkapja I. Lajos királytól Inakháza birtokot (ArhIstRom 2/2004. 2. sz. 8-9. = DL 27438). Pecsétje: TelOkl I. 132. Testvére: $\rightarrow$ János létai (1364) és bálványosi (1364-1371) várnagy, illetve B-Szolnok vm. isp. (1370). 33

derenki cs: Derencsényi

Ders magister (KK?), Küküllő vm. isp. (1331). Talán azonos azzal a Tamás fiával: Ders-sel, aki Hidegvízen (FH) birtokos (1326: CDTrans II. 570. sz.). 81

\section{Dévai Pál 1. Barcsai Pál}

Devecseri (DO; Kádár-Tagányi III. 301)

- András deák (litteratus), Doboka vm. isp. (1455). Ügyvéd (1446: KmJkv I. 571. sz.). 41

Devecseri ([feldevecseri], DO; Kádár-Tagányi III. 301; Feldevecser = Kisdevecser)

- Mihály (Miklós fia), Doboka vm. alisp. (1429-1430); Doboka vm. szolgabírája (1431-1436). Feldevecseren birtokos, a jószág egy részét bírság fejében átadja Császi Mátyás deáknak (1414: ZsOkl IV. 2642. sz.), akit utóbb meggyilkol; feldevecseri jószágrészei az áldozat özvegyéhez és gyermekeihez kerülnek (1421: иo. VIII. 1059. sz.). Talán azonos azzal a Feldevecseri Mihállyal, aki alvajdai ember (1405: WassLt 265. sz.) és aki igényt támaszt
Pulyon, Szentegyed, Borzás, Móric és Jankatelke egyes részeire (DO; 1408: uo. 277. sz.). 38

devecseri cs: Fenesi

Devecseri Fábián, Doboka vm. jegyzője (1520-1525) 1. Kisdevecseri Fábián

Dezméri (KL; Csánki V. 462, 553; Engel: Gen., Mikola rokonsága 7. tábla: Mikola [dezméri, szamosfalvi])

- Miklós (Mikola fia), Kolozs vm. szolgabírája (1315). 66

- Tamás, Kolozs vm. szolgabírája (1408-1410, 1413-1417). Mikola fia: Mihály fia (Csánki V. 553; 1417: ZsOkl VI. 371. sz.). 70

Dezső (patai, KL; Csánki V. 462-463, 764). L. még Patai cs.

- Antal, Doboka vm. és Kolozs vm. isp. (1460). László fia (1459: KmJkv I. 1334. sz.). Felesége: Zsombori Tamás leánya: Anna (1461: uo. I. 1461. sz.). Mérán, Koródon (KL, 1459: uo. I. 1334-1335. sz.; 1484: TelOkl II. 164), Patán (KL, 1467: KmJkv I. 1749. sz.) és Fehér vm.-ben is birtokos (1461: uo. I. 1552. sz.). Ügyvéd (1459, 1482: uo. I. 1389, 2418. sz.), fogott bíró (1467, 1483: ио. I. 1750, 2430. sz.), királyi ember (1468: uo. I. 1800. sz.; TelOkl II. 92). 41

- György, Torda vm. isp. (1447-1448). 87

- János, Torda vm. isp. (1447-1448). 87

Dezsőfi (losonci; BSz; Engel: Gen., Tomaj nem, 6. tábla: Losonci Dezsőfi)

- János, Torda vm. isp. (1508). B-Szolnok vm.-ben birtokos (1501: KmLt = DF 275351). Mihály fia (1502: Veress: Acta et epistolae IV. 61-62). 1500 k. intézkedik Csicsó vár (BSz) és tartozékainak István (Ştefan) moldvai vajda részére történő átengedéséről (Iványi: Bánffy 96; DL 30065; 1502: Veress: Acta et epistolae IV. 61-62). 1502-1503-ban 
Csicsó várából részt kap, de ezt továbbadja. Utoljára 1519-ben említik; családja vele fiágon kihalt (Iványi: Bánffy 95-96). 1505. évi ispánsága nem igazolható (uo. 628). 89

Diósi (de Diogh)

- Ferenc, Doboka vm. isp. (1530). 46

Dobai (KSz; Csánki I. 570; V. 463)

- Gergely, Kolozs vm. isp. (1458). 75

Doboka, Doboka vm. névadó ispánja (1000 k.?), Anonymus említi 1200 k. Csanád fia. 31

Dobokai (DO; Engel: Gen., Kökényesradnót nem, 1. tábla: Dobokai)

- János, Doboka vm. isp. (1404), erd. alvajda (1406-1409, Engel: Arch. I. 14). Magister, János fia (1391, 1403: ZsOkl I. 1982. sz.; II/1. 2865. sz.). 36

- Miklós, Kolozs vm. isp. (1429-1430). Talán Dobokai János erd. alvajda (1406-1409) fia (Engel: Gen.; 1439: BánfOkl II. 628). 73

- Miklós, Doboka vm. isp. (1317). Magister, $\rightarrow$ Mikod bán és dobokai isp. fia (1295: CDTrans I. 540. sz.). Magister; János, Miklós, László, Mihály (1312: uo. II. 202. sz.) és Leukus apja (1337: uo. II. 928. sz.). Csoboló (DO) birtokosa (1312: uo. II. 202. sz.). Egregy (BSz) és az ottani vám birtokosa, I. Károly kir.-t ennek első erdélyi útja alkalmával fogadja (1310: uo. II. 174. sz.). Mészkő, Kerekegyház és Igrictelke (Aranyosszék, 1311: uo. II. 182. sz.), Bányabükk (KL, 1322: uo. II. 437. sz.) birtokosa. I. Károly kir. Doboka vm.-i birtokokat adományoz neki (1317: uo. II. 265. sz.). Királyi ember (1320: uo. II. 356. sz.). 32

- Mikod (Micud) ispán, Doboka vm. isp. (1262-1268 k., 1274?). Szörényi bán (1275-1276: RegArp II/3-4. 2660-2663, 2708. sz.). Kökényesradnót nb. Mykud comes fia ([1262 k.], 1269, 1279: CDTrans I. 236, 278, 368. sz.; En- gel: Gen., Kökényesradnót nem, 1. tábla: Dobokai). 1262 k. testvérével együtt - IV. Béla kir.-tól - adományba kapta Szentmiklós (TD) birtokot ([1270-1272], 12[8]8: CDTrans I. 236, 295, 434. sz.). 1269 e. csatlakozott István ifjabb kir.-hoz, akinek a Doboka vm.-i ispánságot átadta. Istvánt Déva vára alatt, a kunok ellen vívott ütközetben és a feketehalmi és isaszegi csatában is támogatta IV. Béla kir. ellenében (1269, [1270-1272]: uo. I. 275, 278, 294. sz.). Mindezekért adományként kapta Bálványost és Németit (BSz, 1269, 1270: uo. I. 275, 286. sz.), továbbá - egy kétes hitelű oklevél szerint - Jenő (BSz), Boc, Csoboló, Csépántelke (DO) birtokokat (1269, 1270, [1270-1272]: uo. I. 278, 285, 294. sz.). 1269 k. IV. Béla kir.-tól adományba kapta Koppánd és Ivánkatelke/ Koppánd birtokot (FH, uo. I. 281. sz., az adományt később V. István és IV. László kir. is megerősítette, uo. I. 296, 378. sz.); V. István kir.-tól pedig Doboka, Lozsád (DO), Igrictelek és Kerekegyház (TD/Aranyosszék) birtokokat kapta meg ([1270-1272]: uo. I. 294. sz., uo. I. 368. sz.). Megvásárolta Radnót birtokot (FH, uo. I. 422. sz.). Makótelke és Jobostelke (FH, 1295, 1297: uo. I. 540, 564. sz.), továbbá Garáb (NO) birtokosa, Lóna nevü birtokát (KL) elcserélte Újvár és Faludi (FH) birtokokra (1298: uo. I. 566. sz.). 1298-ban Jenő és Csoboló nevü birtokokat Erzsébet nevü leányára és ennek férjére: Chente (d) Jánosra hagyja (1289: uo. I. 574. sz.). $\rightarrow$ Miklós magister és Péter (1300: uo. I. 595. sz.), továbbá Csente Jánosné Erzsébet apja; † 1298 u. (1289: uo. I. 574. sz.; vö. Zsoldos: IV. Béla és István 46-48; Wertner M.: A Kökényes-Rénold-nemzetség Erdélyben. In: EM 12/1895. 347-351; 
Karácsonyi: Nemzetségek 796; Zsoldos: Archontológia 50, 148, 337). 31-32

Dobszai ([gyerőmonostori], KL; Csánki V. 463-464)

- Antal, Doboka vm. isp. (1505). Fogott bíró (1508: KmJkv I. 3458. sz.). Felesége: Gyerőmonostori Radó András és Ilona leánya: Katalin (1493: KmJkv II. 2887. sz.; BánfOkl II. 316), gyermekei: Zsigmond, Borbála, Anna és Margit (1494: Kemény cs malomfalvi 1t, DF 257836). 44

Domokos (Bezter fia), Küküllő vm. szolgabírája (1331) l. Haranglábi

Drági (DO; Csánki V. 464; Engel: Gen., Brassói-rokonság 2. tábla: Drági; 1492: KmJkv II. 2772. sz.; Gündisch, Konrad G.: Das Patriziat siebenbürgischer Städte im Mittelalter. KölnWeimar-Wien 1993. [Studia Transylvanica 18]. 426-428).

- (de Dragy) Ferenc, Doboka vm. isp. (1421 e.?). Nevét 1416-ban említik (TelOkl I. 424-425); leánygyermekei 1417-ben hajadonok (ZsOkl VI. 995. sz.); utolsó ismert említése 1421-ből való (ZsOkl VIII. 1148. sz.). Felesége: Gyerő fia: István leánya: Margit (1416: TelOkl I. 424). Özvegyét 1456-ban említik (1456: KmJkv II. 1251. sz.). Vélhetőleg vele azonosítható az a Franciscus de D[---], aki 1408-ban Kolozs vm. isp. és Léta várnagya (1408: TelOkl I. 342). $\rightarrow$ Jakab kolozsi és $\rightarrow$ László dobokai ispánok testvére (Engel: Gen.). 37

- „Nagy” Jakab (1440: KmJkv I. 189. sz.). Kolozs vm. isp. (1417-1419), létai (KL) várnagy (1419: ZsOkl VII. 1000. sz.; Engel: Arch. I. 249), 1422 e. hátszegi (HD) várnagy (TelOkl I. 459; idézi: Engel: Arch.), Doboka vm. isp. (1429-1431), [Belső-]Szolnok vm. isp. (1431). 1449-ben vajdai ember (KmJkv I. 659. sz.). $\rightarrow$ Bogáti Imre leánya: Bri- gitta férje (1422: TelOkl I. 459; forrás: Engel: Gen.). Zsigmond és Torockói Péterné Hedviga apja (1462: KmJkv I. 1655. sz., idézi Engel: Gen.). $\rightarrow$ László magister és $\rightarrow$ Ferenc dobokai ispánok testvére (Engel: Gen.). 27, 38, 72

- László magister, Doboka vm. isp. (1397-1400, 1406), Középszolnok vm. isp. (1407: DL 65396). Drági Jakab fia: Péter fia, a Zsomboriak osztályos atyafia, Szászzsomboron (DO) birtokos (1407: ZsOkl II/2. 5756. sz.). Királyi kiküldött (1421: ZsOkl VIII. 1148. sz.). $\rightarrow$ Jakab és $\rightarrow$ Ferenc dobokai ispánok testvére (Engel: Gen.). 35-36

- Márton, Kolozs vm. isp. (1512-1514). Zsigmond fia, Kékesen (DO) birtokos (1482: KmJkv I. 2403. sz.). Egregius (1507: uo. II. 3445. sz.). Drágon jószágrészt vásárol (1500: uo. II. 3119. sz.), Órmezőn, Borzován és Farkasmezőn (DO) birtokos (1505: uo. II. 3345. sz.). [Az 1514-es] „keresztes” háborúban megölték (1544: uo. II. 4830. sz.). Felesége: Zsófia, aki első férje halála u. Károlyi Lancz Lászlóné (1524: uo. II. 3996. sz.), gyermekei: Ferenc, Zsigmond (egregiusok) és Károlyi Zsigmondné Anna (1516, 1544: uo. II. 3615, 4830-4831. sz.). 78

[Ebesfalvi] (KK; Györffy III. 551; Csánki V. 925-926)

- Oppor, Küküllő vm. szolgabírája (1331). Sarus fia: László fia, comes jószágrészt vásárol Újlak birtokon (KK, 1325: CDTrans II. 531. sz.). 1337-ben Apour comes és fia: László Gyákoson birtokos (1337: KK, иo. II. 941, 951. sz. = Ub III. 239). Oppor fia: Szentiváni László leszármazottai Ebesfalván (KK) birtokosok (1351: CDTrans III. 617. sz.; 1395: Ub III. 113-116). 81

Écs (Ecce), Geregye nb.-i (Engel: Gen., Geregye nem 1., Écs ága; Karácsonyi: Nemzetségek 459). Erdélyi vajda 
és Fehér vm. isp. (1200: RegArp I/1. 189. sz., Eth), újvári isp. (1201: uo. I/1. 194-195. sz.), Kolozs vm. isp. (1215: CDTrans I. 79. sz., Ecce). Az adatok forrása Zsoldos: Archontológia 37, 151, $163,216,299.66$

Egresi (petlendi, TD; Csánki V. 764; Petlend elnéptelenedett település Túr határában)

- Tamás, Torda vm. szolgabírája (1508-1512). Petlenden birtokos (1520, 1532: KmJkv I. 3785, 4369. sz.). Fogott bíró (1520: uo. I. 3776. sz.). 89

Egresi (TD; Csánki V. 764; a család Egres, Bucs és Indal helységekben birtokos)

- István, Torda vm. szolgabírája (1440). István és György apja (1443?: KmJkv I. 481. sz.). Ügyvéd (1441: uo. I. 338. sz.; 1453: uo. I. 1103. sz.). 87

egresi cs: Császári

Egyed (kidei, DO)

- István, Doboka vm. szolgabírája (1510). Miklós fia (1528: KmJkv II. 4221. sz.). Kidén birtokos, itteni udvarházát bádokira cserélte (1529: uo. II. 4261. sz.). 44

Elekesi (FH) Boldizsár, Fehér vm. szolgabírája (1536). 54

elekesi cs: Komjátszegi

endrédi cs: Bekes

Erdélyi (csomafáji, DO, KL; Csánki V. 465, 617)

- Péter, Kolozs vm. isp. (1444). Nem azonos (tévesen: Csánki V. 617) $\rightarrow$ csomafáii [Tót] Péterrel, Doboka vm. szolgabírájával (1429-1430), mert utóbbi 1439-ben már halott (1439: DL 26885). 74

Erdélyi (ilyei, HD)

- Mihály, Hunyad vm. isp., Hunyad vár várnagya (1531). Királyi ember (1532: Amlacher: Broos 104-105). 64

Erdély (Erdely, kerelői, KK; Csánki V. 883)
- János, Torda vm. isp. (1484-1487). Valószínűleg azonos azzal a Kerelői Jánossal, aki Pál fia, Kerelőn (1468: KmJkv II. 1820. sz.) és Dányánon (KK) birtokos (1492: uo. II. 2798. sz.). 88

Erdélyi (somkeréki, BSz; Csánki V. 467-470; Engel: Gen., Becsegergely nem, 4. tábla: Erdélyi, somkeréki; Décsényi Gy.: A somkeréki Erdélyi család 1415. évi czimeres levele és nemzedékrendje. In: Turul 10/1892. 105-112)

- László magister, Doboka vm. isp. (1350). Geleth fia $(1325,1329,1364$ : CDTrans II. 533, 664. sz.; TelOkl I. 133), Katalin férje, Geleth apja (1399: WassLt 239. sz.), Mihály, Miklós, Gelet, László, András apja (1364: TelOkl I. 133). Testvéreivel együtt Virágosberek, Somkerék, Sajóudvarhely, Szekérbréte, Kócs részbirtokosa (BSz; CDTrans II. 1325, 1329, 1333: 533, 664, 776-777. sz.). Magister (1364: TelOkl I. 133). 33

- Miklós (Antal fia), erd. alvajda (1448, lásd Engel: Arch. I. 15), Torda vm. isp. (1448). Erdélyi Antal alnádor (1423) fia ([1430?]: KmJkv I. 44. sz.; Engel: Gen.). Egregius (1449: KmJkv I. 685. sz.). Felesége: Apafi Anna (1451: uo. I. 986. sz.). Gyermekei: László, Ilona, Katalin, Dorottya (1449: uo. I. 685. sz.), Zsombori Lászlóné Potenciána (1451, 1473: uo. I. 986, 2027. sz.) és István (1470: uo. I. 1935. sz.) [erd. alvajda] és Görgény (TD) várnagya (1465: TelOkl II. 87). 87

Erdős (mányiki, DO; Kádár-Tagányi V. 130)

- János, Doboka vm. szolgabírája (1464-1465). Ügyvéd (1461, 1462: KmJkv I. 1567, 1658. sz.). Széplakon (KL) jószágrészt vásárolt (1497: uo. II. 3027. sz.). 1456-ban a királyi kúriából kiküldött királyi ember a bálványosi uradalom iktatásánál (BánfOkl I. 699; 
DL 27898; vö. Kádár-Tagányi V. 130), alvajdai ember (1488: DL 27552). 41 esküllői cs: Ördög

Esztári (de Eztar [= Sztári, mindszenti], BI; Engel: Gen., Hontpázmány nem 10. Szentjánosi ág, 1. tábla: Esztári és Battyáni)

- Imre, Kolozs vm. isp. (1416). Benedek fia („Benefia”), Bebek Ferenc familiárisa (1403: iktári Bethlen cs 1t, DF 255015, a cs birtokai: Megyer, Szentjános, Marja, Fancsika, Bozinta; BI). Csáki Miklós familiárisaként bihari alisp. (1422). Azonosítására és a forrásokra lásd Engel: Arch. II. 70-71. 71

Esztényi (DO; Csánki V. 471; Kádár-Tagányi III. 420)

- István, Doboka vm. isp. (1450). Mihály fia (1452: KmJkv I. 1001. sz.), Antal apja (1461: uo. I. 1550. sz.). Esztényen és Lónán birtokos (DO; 1441: uo. I. 321. sz.). 40

esztényi cs: Kis, Marói

Eth, erd. vajda és Fehér vm. isp. (1200) 1. Écs

Eustachius, Doboka vm. isp. (1165-1166) 1. Lesták

Ezbwdy (Izbugyai/Zbugyai?) Bernát, Doboka vm. isp. (1476). 43

Farky Pál, Kolozs vm. isp. (1494) 1. Zsuki Pál

farnasi cs: Veres

Fegyveres (kidei, DO)

- György, B-Szolnok vm. alisp. (1485-1487). Eml.: 1493, 1496: KmJkv I. 2879, 2994. sz. 28

Fejér (németi, HD; Csánki V. 178; Németi = Marosnémeti, HD; talán a Hermán nemzetségbeli Németi cs egyik ága)

- Péter, Fehér vm. alisp. (1478-1483). Hunyad vm.-ben birtokos (1468: KmJkv I. 1824. sz.). Királyi (1468: DL 27499) és vajdai (1485: DL 27548) ember. $52-53$ feldevecseri cs: Devecseri, Kis

Felpestesi (HD, Hermán nb.; Csánki V. 180, 244)

- András, Hunyad vm. isp. (1536). 64

- Zakariás, Hunyad vm. isp. (1496, 1500). Zacharias Felpesthewsy de Nemethy (1485: KmJkv II. 2519. sz.). Georgius Zacharias de Pesthes, királyi ember (1504: Pesty: Krassó III. 477; Csánki V. 244). 59-60

Fenesi (devecseri, göci, DO; Nagydevecseren birtokos család; 1396: ArhIstRom 2/2004. 2. sz. 23-24. = DL 27442/1; Kádár-Tagányi III. 299-300)

- László, Doboka vm. szolgabírája (1407). 36

- László, Doboka vm. szolgabírája (1439). Devecseren birtokos (1441: KmJkv I. 386. sz.). 39

- Mihály, Doboka vm. szolgabírája (1493-1494). Felesége: göci Lőcse Margit (KmJkv I. 2093, II. 2979. sz.), fia: Gothárd (uo. II. 3266. sz.). 1496-ban devecseri Fenesi Mihály. Göcön és Kisdevecseren birtokos (DO, ио. II. 2979, 3266. sz.). Országbírói (1482: TelOkl II. 159) és vajdai kiküldött (1499: DL 27577). †1503. I. 15. e. (KmJkv II. 3266. sz.). 44

Ferenc deák Hunyad vm. isp./alisp., hunyadi várnagy (1446-1454) 1. Páznádi Ferenc

Ficsor (Phicor; TD; Csánki V. 772) János, Torda vm. isp. (1463). 88

Fodorházi (DO; vagy Korpádi, KL; Csánki V. 528-529)

- András, Doboka vm. szolgabírája (1443-1445). János (KmJkv I. 620. sz.) és mányiki Gáltői Jánosné Dorottya apja (uo. II. 2603. sz.). Ügyvéd (1441, 1461: uo. I. 308, 1625. sz.). Korpádon birtokos (KL, uo. I. 1012. sz.), Kovácsiban (uo. II. 2877. sz.) és Babócon zálogbirtokos (1493: DL 27559). Deák 
(1457: KmJkv I. 1276. sz.; 1461: DL 27322; KmJkv I. 1625. sz.). 1447-ben tiltakozott az ellen, hogy a férfiörökös nélküli Korpádi György bevallásokat tegyen Korpád és Pata (KL) birtokbeli részeit illetően, vagy hogy ezeket bárki adományul kérje a királytól (uo. I. 620. sz.). Fodorházi András fia: János korpádi örökjogú jószágrésze a Korpádiaknál volt zálogként lekötve (1452: DL 27027). 39

Fodorházi 1. még Korpádi

Folti (HD; Csánki V. 181-183)

- László, Hunyad vm. isp. (1510-1511), Vajdahunyad várnagya, Brandenburgi György familiárisa (1511: Brandenburger Lit., 1056/8 = DF 267268. = Pataki: Hunedoara 154 = Pesty: Krassó III. 496-497). Hunyad vm. szolgabírájával: $\rightarrow$ Kisbarcsai Mihállyal együtt bocsát ki oklevelet (1520: Jósika cs hitb. lt, DF 257630). 1504-ben II. Ulászló kir.-tól Hunyad vm.-i jószágrészeket kapott (Pesty: Krassó 476-478). Királyi ember (1493: DL 29875; 1523: Veress: Acta et epistolae IV. 128. = DL 31040). 61

Fonói ([TO, Bágyon-fi Benedek fia])

- János magister, besztercei, kolozsi és kolozsvári ispán (1317). 1324 e. az erdélyi részek kapitánya, királynéi pohárnokmester, I. Károly kir. híveként részt vesz Erdély visszafoglalásában (1324: CDTrans II. 482. sz.), raholcai várnagy (1321-1323), királynéi pohárnokmester és verőcei ispán (1323-1324; lásd Engel: Arch. II. 76; uő: Az ország újraegyesítése. I. Károly küzdelmei az oligarchák ellen. In: Honor, vár ispánság. Válogatott tanulmányok. Bp. 2003. 345, 395). 66

\section{Forró ([háportoni], $\mathrm{FH}$ )}

- Tamás, Fehér vm. helyettes alisp. (1522). Ecsellőn (FH) birtokot vásárol (1501: KmJkv II. 3202. sz.); Lapádon
(FH), Fügeden (TD), Lapupatakon, Vásártelkén és Argyason (KL) jószágrészt vesz zálogba (1519, 1520, 1528: uo. II. 3721, 3781, 4213-4214. sz.); Bényén (KK) zálogbirtokos (1519: TTár 1907. 117); háportoni (1516: KmJkv II. 3618. sz.). Nádori (1507: DL 30071) és királyi ember (1514: KmJkv II. 3585. sz.); fogott bíró (1522: uo. II. 3865. sz.). 53

Forrói (FH; Iczkovits 54)

- János, Fehér vm. szolgabírája (1525). 54

- Imre, Fehér vm. szolgabírája (1435). 52

- Mihály, Fehér vm. szolgabírája (1342-1348), vajdai közgyülésen ülnök (1344: CDTrans III. 227. sz.). Alvajdai ember (1347, 1348: uo. III. 425, 483. sz.). 51

- (Forray, de Forro) Miklós, Fehér vm. szolgabírája (1406-1408). Péter fia. Szentkirály, Bagó (FH), Mócs, Báld, Csehtelke és Gyéres (KL), Jakabfalva $(\mathrm{KK})$ birtokokban jószágrészeket vásárol (1414: ZsOkl IV. 2363. sz.; vö. 1413: uo. IV. 1206. sz.); királyi ember (1421: uo. VIII. 852. sz.). 51

- Péter comes Fehér vm. szolgabírája (1303). Fogott bíró (1308: CDTrans II. 81. sz.). Királyi ember (1299: uo. I. 589. sz.). 49

Földvári (de Fewdwar, [vajdaszentiványi], TD; Csánki V. 773)

- Imre, Torda vm. alisp. (1453). 88

Frank (kidei) 1. Kidei Frank Gergely, Doboka vm. szolgabírája (1493)

Frátai (KL; Csánki V. 475-477)

- Imre (Beke fia), Kolozs vm. szolgabírája (1386). Fráta (KL) birtokosa (1369: DRH. C. XIII. 664; 1377: uo. XV. 330). Alvajdai ember (1374: BánfOkl I. 325). 69 
- János, Kolozs vm. szolgabírája (1439). Alvajdai ember (1424: TelOkl I. 470). 74

Frátai (KL; Márkházi, DO; Csánki V. 337, 358, 475-476)

- Péter magister (Gál fia), Doboka vm. szolgabírája (1384, [1384-1392?], Márkházi Gál fia: Péter), Kolozs vm. szolgabírája (1398, 1403-1407). Both fia: János fia: Gál fia Frátán (KL, 1355: DRH. C. X. 365) és Botházán birtokos (KL, 1402: ZsOkl II/2. 1593. sz.). István és László testvére (1401: TelOkl I. 281). Vajdai ember (1380: uo. I. 197). Jogtalanul használta Keszüt (KL, 1392: WassLt 216. sz.). Testvéreivel együtt román falut telepített Fráta területén (1391: DocVal 414). A Magyarfrátán, Oláhfrátán, Botházán (KL) és Márkházán birtokos János apja, akivel ez a fiúág kihalt (1440: DL 3031; DL 27484). Pecsétje: TelOkl I. 264. 34-35, 70

frátai cs: Báncsa, Szentes

Furka (keresztúri; HD; Csánki V. 183)

- Balázs, Hunyad vm. szolgabírája (1492-1494). Miklós fia, Keresztúron és Bóson (HD) birtokos (1496: HunyadmÉvk 1/1880-1881. 69-73). Királyi kiküldött (1506: DL 29914). 58-59

Fülöp, Doboka vm. isp. (1272), egyidejűleg királyi pohárnokmester (1270-1272). Korógyi Keled fiával azonosítható (Zsoldos: IV. Béla és István. 116-118; vö. Engel: Gen., Korógyi). További tisztségeire és az azonosításra lásd Zsoldos: Archontológia 302. 32

Fürményesi (KSz; Csánki I. 555)

- Mihály, Doboka vm. szolgabírája (1379-1380). András fia, hihetőleg a Középszolnok vm.-i Fürményes birtokosa (1358: DRH. C. XI. 272). Alvajdai kiküldött (1371: uo. XIV. 17). 34

gáji cs: Mocsk
Gál, Fehér vm. isp. (1177 k.), Kolozs vm. isp. (1183). 49

- magister (Pascha fia), Kolozs vm. isp. (1353), B-Szolnok vm. isp. (1355) 1. Járai Gál

Galaci (DO; Csánki V. 477-478)

- János (Demeter fia), Doboka vm. szolgabírája (1350, 1361-1362). Galaci (DO); az 1350-es években több alkalommal királyi, vajdai és alvajdai kiküldött $(1353,1356,1357$ : CDTrans III. 709, 869, 898, 928, 971. sz.). +1362. XII. 13. e. (DRH. C. XII. 114-115). 33

- Lőrinc, B-Szolnok vm. isp. (1471). Péter fia, Galacon (DO) és Lompérdon (KL) birtokos (1463: KmJkv I. 1660. sz.), ügyvéd (1480: uo. I. 2309. sz.). 28

- Miklós, B-Szolnok vm. isp. (1405). Gyermekei: Péter, László és Katalin, akik Szentjakab és Bő (TD) birtokukat eladják (1413: ZsOkl IV. 743. sz.). Királyi ember (1402, 1407: TelOkl I. 287, 322). 26

galántai cs: Besenyő

Gáldi (FH; Iczkovits 55)

- Ferenc, Fehér vm. szolgabírája (1511). Királyi és nádori ember (1499, 1507: KmJkv II. 3077. sz., DL 30071). 53

- László, Hunyad vm. isp. (1505). 60

gáldi cs: Cucor

Gáldtői (FH; Iczkovits 55)

- Benedek, Fehér vm. szolgabírája (1515). Vajdai ember (1515: TelOkl II. 342). Zsófia férje, Barnabás és Ferenc apja, Pókán (TD) és Ercsén (KL) jószágrészt vásárol (1495: KmJkv II. 2955. sz.). 53

- Kelemen, Fehér vm. kapitánya (1525). Tamás fia (1509: KmJkv II. 3484. sz.), Magyarbényén, Oláhbényén (KK) és Lombfalván (FH) birtokos (1527: uo. II. 4191. sz.). 54 
- Péter, Fehér vm. alisp./isp. (1451, 1455). Ügyvéd $(1468,1471,1482$ : KmJkv II. 1826, 2027, 2357. sz., az erd. püspökség gubernátorának ügyvédje), királyi ember (1479: DL 26432). 52

- Tamás, Fehér vm. szolgabírája (1499). Zsigmond, Gergely, Kelemen, István, Orsolya, Potenciána, Dorottya és Klára apja (1509: KmJkv II. 3484. sz.). Vajdai (1493, 1506: DL 36875, 26491), királyi (1501: KmJkv II. 3193, 3203. sz.) és nádori ember (1507: DL 30071). 53

gáldtői cs: Sülyei

Gegus magister, B-Szolnok vm. szolgabírája (1325) 1. Apafi Gegus

Gálfi (hosdáti; HD; Csánki V. 154)

- Bálint, Hunyad vm. szolgabírája (1544). 64

Gerendi (TD, Tyukod nb.; Csánki V. 479, 774-777; Karácsonyi 1039; Engel: Gen., Tyukod nem, 1. tábla: Gerendi; Gyulai R.: Adatok a Gerendi család történetéhez. In: Genealógiai Füzetek 4/1906. 49-52)

- László, Torda vm. isp. (1508). Miklós és Dobokai Anna fia, Miklós erd. püspök testvére (Engel: Gen.). Feleségei: 1. Czeke János leánya: Gedrud/ Ieronyma/Gera, dicsőszentmártoni Sándor János özvegye (1507: TelOkl II. 296; 1510: KmJkv II. 3547. sz.); 2. Váncsa Márta (Váncsa János és Haranglábi Ilona leánya, 1532: uo. II. 4380. sz.). $\rightarrow$ Márton apja (1522: uo. II. 3837. sz.). Egregius (1520: иo. II. 3782. sz.). Bányabükk, Rőd (KL), Füged, Szentmárton, Cikud, Szentkirály birtokosa (TD, 1520, 1522, 1523: иo. II. 3781, 3784, 3787, 3792, 3860, 3894. sz.); Szelicse zálogbirtokosa (TD, 1524: uo. II. 4017. sz.). Megszerzi Dicsőszentmárton mezővárost (KK) és Péterlaka (FH) birtokot (1513: TelOkl II. 317; 1517: KmJkv II. 3622. sz.). Megvásárolja Szentmártont (TD, uo. II. 3782-3783. sz.). Királyi ember (1515: TelOkl II. 343, 347). 89

- Márton, Torda vm. isp. (1536). $\rightarrow$ László fia (1522: KmJkv II. 3837. sz.); István, Borbála és Katalin apja (1550: uo. II. 4989. sz., ekkor néhai). 90

- Miklós comes (Péter fia), B-Szolnok vm. isp. (1325), Torda vm. isp. (1310-1312, 1326), Kán László erd. vajda fiainak familiárisaként létai várnagy (1315 e.), majd I. Károly kir. oldalára állva részt vett Erdély pacifikálásában a polgárháború idején (CDTrans II. 482. sz.; Kristó Gy.: Erdély 1315-ben. In: Emlékkönyv Jakó Zsigmond születésének nyolcvanadik évfordulójára. Kolozsvár 1996. 333-342). Valószínűleg vele azonosítható az a Péter fia: Miklós comes, aki 1325-ben Belsőszolnok vm. ispánja (CDTrans II. 527, 532. sz.). Az Archontológia (I. 200) tévesen Szolnok vm.-nél szerepelteti (a szolgabírák nevéből kiderül, hogy Belsőszolnokról van szó; helyesen: uo. II. 84). Péter fia, Jakab és Miklós apja (1318, 1340, 1345: CDTrans II. 312. sz.; III. 31, 301. sz.). Comes; Bő, Szentkirály, Felgerend, Szarkad, Tordalaka, Örke (TD, uo. II. 23, 168, 197, 312. sz.), Lóna, Egerbegy, Szentmárton, Hadrév, Keresztúr, Cikud (TD, uo. II. 1026. sz.) birtokosa, megvásárolja Bányabükköt (KL, uo. II. 437. sz.). 25, 85

- Péter, Fehér vm. isp. (1546). Egregius; György, János, Márta, Anna, Magdolna, Erzsébet és Katalin apja (1550: KmJkv II. 5001. sz.). 54

Gergely magister (János fia), Kolozs vm. isp. (1373) 1. Bethlen Gergely

Gergely, Doboka vm. isp. (1443). 39

Gergelyfi (hosdáti, HD; Csánki V. 185)

- Bálint, Hunyad vm. szolgabírája (1488). 58

Gesztrágyi (KL; Csánki V. 479-482) 
- Ábrahám, Kolozs vm. szolgabírája (1499). Fogott bíró (1508: KmJkv II. 3458. sz.), alvajdai kiküldött (1513: TelOkl II. 319). Mérai; Koródon (KL) birtokos (1514: KmJkv II. 3584. sz.); mérai Gesztrágyi Ábrahám, királyi ember (1496: BánfOkl II. 335). Leánya: mérai Nagy Pálné Márta (1523: uo. II. 3899. sz.). 78

- Albert, Doboka vm. isp. (1505). $\rightarrow$ Benedek és Margit fia (1495: KmJkv II. 2948. sz.); Margit - sárdi Budai Nagy Gergelyné, majd sárvári Tomori Jánosné - apja (uo. II. 3638, 4602. sz.). Özvegye, Katalin, később Sárdi Pálné. +1518. II. 21. e. (uo. II. 3661. sz.). Birtoka: Gesztrágy, kúriával (KL, uo. II. 3824. sz.). Jószágrésze volt Petlenden (TD, uo. II. 3785. sz.), részt vásárolt Monyoróalján (KL, uo. II. 3390. sz.). Apja, Gesztrágyi Benedek, per útján megszerezte a Budai család több birtokát (Diós, Kölesmező, Óbuda; vö. Csánki V. 480; 1495: DL 26937-26938). 44

- Benedek, Kolozs vm. isp. (1499). $\rightarrow$ Albert apja (1495: KmJkv II. 2948. sz.). Felesége: Budai Margit (1486: иo. II. 2607. sz.). Jószágrészeket vásárolt Buda, Diós és Kölesmező (KL, 1495: uo. II. 2948. sz.), Szomordok (KL) birtokokban (1499: иo. II. 3313. sz.); Szucságon (KL) zálogba vett birtokot (1498: uo. II. 3071. sz.). Fogott bíró (1486: uo. II. 2629. sz.), ügyvéd (1490: uo. II. 2710. sz.), vajdai ember (1494: BánfOkl II. 320). L. még. KmLt 317. sz. = DF 275356 (1500). 78

- László (János fia), Kolozs vm. szolgabírája $(1391,1398) .70$

Girolti (BSz; Csánki V. 482)

- Antal, B-Szolnok vm. szolgabírája (1434-1435). Ügyvéd (1440-1442, 1446, 1448-1450: KmJkv I. 191, 305, 405, 596, 632, 646, 856. sz.). Királyi kiküldött (1439: DL 27872). Téves az az adat, miszerint Bálványos vár (BSz) várnagya lett volna 1449-ben (DL 36391/98/3, idézi Kálniczky: Várnagyok 83), mert az idézett forrás szerint Iklódi Beke és Miklós töltötték be ezt a tisztséget (Engel: Arch. I. 272; KmJkv I. 777. sz.). 27

- Illés, B-Szolnok vm. szolgabírája (1468). 1497-ben néhai (KmJkv II. 3012. sz.), szeszármai Szabó Zsigmondné Margit apja (1503: uo. II. 3276. sz.). Királyi ember (1467: BánfOkl II. 97). 28

- Márton, B-Szolnok vm. szolgabírája (1487). Mihály és György apja, 1497-ben néhai (KmJkv II. 3019. sz.). 29

- Miklós, B-Szolnok vm. szolgabírája (1474). Imre fia, Csepegőmacskáson és Alsótőkön (DO) birtokos (1473, 1483: KmJkv I. 2121, 2443. sz.). Vajdai kiküldött (1472: TelOkl II. 120). Téves az az adat, miszerint Bálványos vár (BSz) várnagya lett volna 1449-ben (DL 36391/98/3, idézi Kálniczky: Várnagyok 83), mert az idézett forrás szerint Iklódi Beke és Miklós töltötték be ezt a tisztséget (Engel: Arch. I. 272; KmJkv I. 777. sz.). 28

- Miklós, Doboka vm. szolgabírája (1495, 1505). Gyermekei: Mátyás, id. Gergely, ifj. Gergely, Albert, Szentiváni Jánosné: Katalin, szászzsombori Roth Jánosné: Ilona, illetve Márta. Alsótőkön jobbágytelkeket vásárolt (1505: KmJkv II. 3378. sz.). 1500-as adat szerint tőki (DO) Girolti Miklós (uо. II. 3140, 3144. sz.). Alvajdai kiküldött (1492: DL 27974). 44

- „Veres (Rufus)” Miklós, B-Szolnok vm. szolgabírája (1407). 27

Gombási (FH?)

- János magister, Kolozs vm. isp. (1351). 67

Göci (DO) 
- [id.] György, Doboka vm. szolgabírája (1456-1462). $\rightarrow$ Demeter és Mátyás apja (1473: KmJkv I. 2093, 2116. sz.). Ügyvéd (1453, 1459: uo. I. 1092, 1348. sz.), alvajdai ember (1455: WassLt 452. sz.). 41

- [Porkoláb?] Demeter, Doboka vm. szolgabírája (1471-1473, 1487). $\rightarrow$ [id.] Göci Lőcse (d) György fia (1473: KmJkv I. 2093, 2116. sz.), György apja (1496: uo. II. 2979. sz.), Zsuki Dávid leánya: Borbála férje (1473: WassLt 465. sz.; 1473: DL 27520). Göcön birtokos (1473: KmJkv I. 2116. sz.). Vélhetőleg azonos göci Porkoláb Demeterrel (1482: DL 27543) vagy azzal a bongárdi Porkoláb Demeterrel, akit - Bongárdi Benedek leánya: Jusztina nevü feleségével együtt, ennek jussán - bongárdi jószágrészbe vezettek be (1488: DL 27552) és aki Veresegyházon és Mányikon szerzett zálogos jószágrészeket (DO, 1496: DL 27569). Szentmihálytelkén birtokos (KL, 1501: KmLt 318. sz. = DF 275354). Országbírói kiküldött (1483: TelOkl II. 159). 42, 44

- Mátyás, Doboka vm. szolgabírája (1505, 1513), Göci Porkoláb Mátyás, Doboka vm. alisp. (1513). Göci Mátyás vélhetőleg azonos az alisp. Göci Porkoláb Mátyással (1513: WassLt 587. sz.), aki Porkoláb László fia (1495: uo. 489. sz.). Fogott bíró (Göci Mátyás: 1510: uo. 560. sz.), vajdai kiküldött (Göci Mátyás: 1474: DL 27523; 1511: WassLt 568. sz.; 1514: Göci Porkoláb Mátyás: DL 27257). Göcön birtokos, itt kúriája volt (Göci Mátyás: WassLt 544. sz.). 44-45

- Mihály magister, Doboka vm. isp. (1392). László fia, Katalin férje (WassLt 203, 214, 239. sz.; TelOkl I. 310), György apja, Szászzsombor zálogbirtokosa (ZsOkl II/2. 5756. sz.). Gö- cön birtokos (TelOkl I. 295), ismeretlen jogcímen magának követelte a Wass család cegei halastavát (1390: WassLt 205. sz.). Alvajdai kiküldött (1396: ArhIstRom 2/2004. 2. sz. 25. = DL 27442/1), királyi ember (1403: TelOkl I. 295). 35

göci cs: Fenesi

Gula/Jula comes (Artolph/Ortalph fia), Doboka vm. szolgabírája (1315) 1. Gyulai Gula/Jula

Gútkeled nemzetség: Várkői/Várkonyi

gyekei cs: Sztrigyi

gyéresi cs: Cibak

Gyerőfi (gyerővásárhelyi, KL; Csánki V. 487; Engel: Gen., Mikola rokonsága, 3. tábla: Gyerőfi, kiskapusi, inaktelki)

- László, Kolozs vm. isp (1527-1528). Perényi Péter erd. vajda familiárisa (1527: MOL, R 293, Megyei iratok, 5. d, No. 1., f. 1.). László fia (1486: KmJkv II. 2570. sz.). Gyerővásárhelyi, egregius. Felesége: keceli Szele Márton leánya: Klára. Részt vett [Szapolyai János?] 1521-es [havasalföldi?] hadjáratában (1521: uo. II. 3818. sz.). Gyerővásárhely, Kapus, Oláhkapus, Pányik, Bedecs, Szentkirály, Sztána és Szamosfalva (KL) birtokokban voltak jószágrészei (1543: uo. II. 4782. sz.). 80

Gyerőfi (kiskapusi, inaktelki, KL; Csánki V. 486-492; Engel: Gen., Mikola rokonsága, 3. tábla: Gyerőfi, kiskapusi, inaktelki)

- Balázs (János fia; kiskapusi), Kolozs vm. szolgabírája (1493). János fia (1486: KmJkv II. 2588. sz.). Felesége: ónoki Herceg Pál leánya: Adviga (1505: uo. II. 3356. sz.). Kiskapusi (1482, 1485: uo. I. 2405, II. 2542. sz.), magyarkapusi (1483: uo. II. 2436. sz.). Szamosfalva, Magyarkapus, Oláhkiskapus, [Gyerő]vásárhely, Pányik, Bedecs, Sztána, Inaktelke falvakban 
birtokos (KL, 1486: uo. II. 2562. sz.), [Kalota]szentkirályon (KL, 1493: uo. II. 2860. sz.), Sárdon és Újbudán zálogbirtokos (KL, 1500: uo. II. 1329. sz.). Ügyvéd (1489: uo. II. 2704. sz.), a losonci Bánffyak osztályánál fogott bíró (1499: BánfOkl II. 357). 78

- Ferenc (inaktelki), Kolozs vm. szolgabírája (1512). Ábrahám fia (1497: KmJkv II. 3009. sz.). Gyermekei: Szutori Pálné (1527: uo. II. 4200. sz.), majd Zsombori Györgyné Druzsianna és Mihály; birtokai: Inaktelke, Gyerővásárhely, [Magyar]kapus, Oláhkapus, Sztána, Pányik, Bedecs, Szamosfalva, Topaszentkirály (KL, 1549: uo. II. 4932. sz.). Vajdai ember (1501: uo. II. 3173. sz.). Fogott bíró (1516: uo. II. 3609. sz.). 1527-ben néhai (uo. II. 4200. sz.). 78

- Mihály, Kolozs vm. (alisp.?) (1451?). [Gyerő]vásárhelyi János fia: Miklós fia (1441: KmJkv I. 320. sz.). Felesége: Bakaji Zsigmond leánya: Ilona (1449: uo. I. 764. sz.). Gyermekei: Ábrahám, András, Katalin, Orsolya és Ilona (1456: uo. I. 1254. sz.). Inaktelkén (KL) birtokos (1441: uo. I. 320. sz.). Ügyvéd (1441: uo. I. 366. sz.), Lépes Loránd volt erd. alvajdával együtt fogott bíró (1442: uo. I. 435. sz.). + 1458. XI. 23. e. (uo. I. 1324. sz.). Valószínüleg azonos azzal a „Gyerő fia” Mihállyal, aki 1445-ben az erd. püspök makói (KL) birtokát pusztította $(K m L t$ 163. sz. = DF 275273). 75

Gyerőfi (szamosfalvi, KL; Csánki V. 482-486, Engel: Gen., Mikola rokonsága, 2. tábla: szamosfalvi Gyerőfi)

- János („Gyerő fia”), Kolozs vm. alisp./ isp. (1449-1451), Torda vm. alisp. (1453), B-Szolnok (1455) és Doboka vm. isp. (1455). Jószágrészei Szamosfalva, Vásárhely, Kapus, Inaktelke, Sztána, Pányik, Oláhkapus birtokok- ban (KL, 1469: KmJkv I. 1915. sz.) és Keresztes prédiumban voltak (DO, 1454: uo. I. 1122. sz.). István fia (1430: WassLt 406. sz.; 1439, 1460: KmJkv I. 119, 1485. sz.; tévesen László fia, 1450: uo. I. 829. sz.). Korpádi György leánya: Lúcia férje, Péter, Jakab, István, Zsófia és Márta apja (1451: uo. I. 962. sz.). †1460. XI. 25. e. (uo. I. 1485. sz.). Testvére: Gyerőfi István fia: $\rightarrow$ László. 27, 41, 75, 88

- László, Kolozs vm. isp. (1439). István fia (1439, 1454: KmJkv I. 119, 1122. sz.; tévesen László fia, 1450: иo. I. 829. sz.). Vajdai kiküldött (1449: uo. I. 664. sz.). Felesége: Cserényi Pál leánya: Margit (1451: uo. I. 974. sz.), majd Ilona. Fia: Tamás (1460: uo. I. 1458. sz.). Testvére: $\rightarrow$ János. 74

gyerőmonostori cs: Dobszai, Kemény

Gyógyi (FH; Iczkovits 55; Györffy II. 163)

- Gergely comes, Fehér vm. szolgabírája (1320-1322). Péter fia (1318: CDTrans II. 293. sz.), Mihály apja (uo. III. 355. sz.), királyi ember (1320: uo. II. 389. sz.). 50

György magister (Jakab fia), Kolozs vm. isp. (1358-1359) 1. Járai György

Györgyfalvi (v. Henke, KL; Csánki V. 492-497)

- Imre, Doboka vm. isp. (1423). Imre és Péter apja (1423: DL 26770; 1427: TelOkl I. 506; 1431: DL 26881), cegei Wass Junyth férje (1429: WassLt 395. sz.). Györgyfalván (KL, 1417, 1418: ZsOkl VI. 371. sz.; VII. 1419), Pulyonban és Szentgothárdon birtokos (DO, 1427, 1428: WassLt 375, 389. sz.), 1427-ben jogtalanul használt légeni (KL) jószágrészeket (uo. 382. sz.). Örökösei sikertelenül próbálták megszerezni a cegei Wass család által nekik ígért Győr és Veszprém vm.-i Wass-birtokokat (1430: uo. 402. sz.). Testvérével együtt 1420-1430 k. adományként 
megkapta Zsigmond királytól Füzkút és Szentkirály birtokokat (KL, ZsOkl VII. 2440. sz.). 37

- (?) János (Mihály fia), 1. János (Mihály fia), Kolozs vm. szolgabírája (1360-1361). 68

- „Henke” János, Kolozs vm. szolgabírája (1478). „Henke” László fia (1449, 1451: KmJkv I. 764, 989. sz.) vagy „Henke” Domokos fia (1450 k., 1460: uo. I. 923, 1439. sz.). 1494-ben néhai (uo. I. 2918. sz.). $\rightarrow$ "Henke" Salatiel apja (1494: uo. II. 2930. sz.). 76

- „Henke” László, Kolozs vm. szolgabírája (1389-1393, 1398-1402). Alvajdai kiküldött (1384: DL 36881). 69-70

- „Henke” Mihály, Kolozs vm. szolgabírája (1364-1366). Györgyfalvi "Henke" (d) Mihály (1366: DRH. C. XIII. 168), Olah (d) György unokája, Györgyfalván birtokos (1371: TelOkl I. 170). 68

- „Henke” (d) Péter comes, Kolozs vm. szolgabírája (1334). Györgyfalvi „Henke" Péter (1344: CDTrans III. 231. sz.). Királyi és alvajdai kiküldött (1341, 1342, 1345: иo. III. 58, 93, 249. sz.). A Zsukiak állítása szerint rokonaival együtt ezek - Felekfark nevü (KL) - örökjogú birtokát elfoglalta és azt Györgyfalvának nevezve használja (1344: uo. III. 231. sz.). 67

- „Henke” Salatiel, Kolozs vm. szolgabírája (1497, 1513-1514). Györgyfalvi „Nagy Henke (Nag Henke)” (d) Salatiel, olykor „Magnus" Salatiel (1517, 1518: KmJkv II. 3639, 3697. sz.). $\rightarrow$ „Henke” János fia (1494: uo. II. 2930. sz.). Szucságon, Patán (KL) jószágrészt vásárol $(1494,1516,1518$ : uo. II. 2930, 3593, 3689. sz.). Zálogba vett Györgyfalva, Pata, Szentmiklós (1524: uo. II. 3986. sz.), Oláhdezmér (KL, 1524: uo. II. 3989. sz.) birtokbeli részeket. Fogott bíró (1516: uo.
II. 3609. sz.). Vajdai és királyi ember $(1513,1515,1516$ : TelOkl II. 319, 349, 351). Felesége: szancsali Sulyok György leánya: Katalin, gyermekei: Benedek, Sebestyén, Antal, Frátai Salatielné Orsolya és Zsófia (1519: KmJkv II. 3712. sz.). 78

- Kis (Kys, minor) vagy ifjabb (iunior) „Henke” (d) Salatiel, Kolozs vm. szolgabírája (1521-1522, 1525, 1530). Egregius. Felesége: nagylaki $(\mathrm{FH}) \mathrm{Cso-}$ ronk Lőrinc leánya: Ilona, gyermekei: Miklós, Gáspár, János, bagói Miske Miklósné Dorottya és Orsolya (1527: KmJkv II. 4186. sz.). 79-80

Gyula erd. vajda és Fehér vm. isp. (1201) 1. Kán nb. Gyula

Gyulai (DO; Csánki V. 497-498; Engel: Gen., Borsa nem 4. Szentpáli)

- Gula/Jula comes (Artolph/Ortalph fia), Doboka vm. szolgabírája (1315). Gyula (DO) birtokosa (1307, 1329: CDTrans II. 68, 644. sz.). Valószínüleg azonos azzal a Borsa nb. Szentpáli Rodolf fiával: Gyulával, akit 1295-ben (uo. I. 537. sz.) említenek. 32

- János, Doboka vm. isp. (1530-1540). Ügyvéd (1523: KmJkv II. 3917. sz.). Gyulán (DO) birtokos (1533: uo. II. 4403. sz.), Szamosfalva, Kiskapus, Oláhkapus, Pányik, Bedecs, Vásárhely, Inaktelke, Sztána, Topaszentkirály (KL) birtokokban részeket vett zálogba (1531: uo. II. 4353. sz.). Vajdai ember (1516: WassLt 616, 622. sz.). $46-47$

- Lorand (Artolph/Ortalph fia), Doboka vm. szolgabírája (1315). Gyula birtokosa (1307, 1329: CDTrans II. 68, 644. sz.). $\rightarrow$ Szentpáli Gula/Jula comes szolgabíró testvére. 32

Gyulai Mihály, Doboka vm. exactora (1545). 47

gyulai cs: Valkai 
Hacaki (de Hathzak, de Haczak, [sárdi, KL; osztrói, HD]; Csánki V. 499)

- Dénes, Kolozs vm. szolgabírája (1497). Felesége: sárdi Budai Ilona (1499: KmJkv II. 3101. sz.). Gyermekei: Bálint, András, László, Gergely és István (1498: uo. II. 3065. sz.). Sárdon (KL) birtokot szerez (1505: uo. II. 3365. sz.). Fogott bíró (1502: uo. II. 3225. sz.). 1516-ban néhai (uo. II. 3609. sz.). 78

- Gáspár, Kolozs vm. protonotariusa (1544). A kolozsmonostori konvent székének jegyzője (notarius sedis, 1543: KmJkv II. 4797. sz.). 80

Hadrévi (TD; Csánki V. 778-779)

- „Bíró" László, Torda vm. (al)isp. (1446, 1448). A hadrévi nemesek, majd Drági Jakab ügyvédje (1439, 1440: KmJkv I. 165, 201. sz.; vö. 1442: uo. I. 429. sz.). 87

háportoni cs: Forrói

Haranglábi (KK; az alább említendő Bezter név alapján Csánki és feltételesen Karácsonyi is a Nána-Beszter nemzetséghez sorolja; Csánki V. 499, 930-934; Karácsonyi 1097; Engel: Gen., Haranglábi)

- Domokos (Bezter fia), Küküllő vm. szolgabírája (1331). 1344-ben vajdai közgyülésen ülnök (1344: CDTrans III. 227. sz.). 1350-ben néhai (uo. 557. sz.). Haranglábi (1358: uo. III. 1016. sz.). 81

- Gál, Kolozs vm. isp. (1426-1427). Fia: Zsigmond (1441: KmJkv I. 380. sz.). Felesége: Zsuki János leánya: Veronika (1482: uo. I. 2388. sz.). Jószágrészei: Harangláb, Gálfalva, Telek, Désfalva, Boziás és Sáros (KK). 1441-ben néhai (uo. I. 380. sz.). 73

- Miklós, Küküllő vm. isp. (1532-1536). Egregius (KmJkv II. 4320. sz.). Zsigmond fia (1491: uo. II. 2756. sz.). Felesége: losonci Bánffy István leánya:
Borbála (1523: uo. II. 3922. sz.). Désfalván (KK) birtokos (1538: uo. II. 4671. sz.). 82-83

Harói (HD; Csánki V. 186)

- Bálint, Hunyad vm. szolgabírája (1505). Harói Harói (Harray de Harro) Bálint, 1499-ben vajdai kiküldött (DL 30238). 60

- Demeter, Hunyad vm. szolgabírája (1390). Harói Barnabás fia, királyi ember (1362: DRH. C. XII. 90-91; 1390: Ortvay: Temes I. 188. és 196). 56

- János, Hunyad vm. szolgabírája (1481). 58

- Máté, Hunyad vm. szolgabírája (1503). 60

harói cs-ok: Berecki, Csikós, Csuka, Horvát, Kis

Hátszegi 1. Hacaki

héderfájai cs: Lökös

Henke 1. Györgyfalvi „Henke”

Herepei (bényei, KK; béldi, herepei, $\mathrm{FH}$ )

- Gergely, Fehér vm. alisp. (1511-1515, 1522, 1524-1525). Béldi (1522: DL 67262). Bényei, alisp. (1524: DL 67263); herepei, Bényén (KK) jószágrészt vásárol (1527: KmJkv II. 4188. sz.). Egregius (1526: uo. II. 4141. sz.). Meggykerék 1501. évi iktatásánál szomszéd birtokos (uo. II. 3203. sz.). Királyi ember (1515, 1518: DL 30270, TelOkl II. 371). Oláhbényén (KK) és Lombfalván (FH) birtokos, 1522-ben familiárisát említik (KmJkv II. 3865. sz.). Felesége: bényei Temesvári Orsolya (1530: uo. II. 4293. sz.), majd Tötöri István leánya: Ilona; első feleségétől gyermekei: Katalin, Potenciána, Magdolna és Fruzsina. Első felesége révén Berenden (KL) birtokos (1526: uo. II. 4141. sz.). Kalotaszentkirályi (KL) jószágrészét bényeire cseréli (1524: DL 67263). 53-54 
Herepei (FH; Csánki V. 935; Iczkovits 56)

- István, Jakab és Mihály, Küküllő vm. alispánjai (1448). A Herepei család Küküllő vm.-ben is birtokos (Ub III. 456; 1462: DL 27676, idézi Csánki V. 935). 82

- Péter, Fehér vm. isp. (1471). Felesége: Ilona, fiai: Mihály és Gergely (1475: DL 30894). 1476-ban az erd. kápt. Magyarorbói (FH) birtokát pusztítja (1476: KmLt 238. sz. = DF 275418). Királyi (1479: DL 26432) és vajdai ember (1469, 1479: DL 29298 és 26432). 52

Herepei (FH; [szentlászlói, KL; Csánki V. 407-408; Szentlászló = Tordaszentlászló])

- „Erdélyi” (1439: DL 29468) Márk, udvari lovag (1433-1439), erd. alvajda (1446-1450), Torda vm. isp. (1448). Szentlászlói András fia (1433: Lukcsics II. 290. sz.). Özvegye: szamosfalvi Gyerőfi László leánya (1451: KmJkv I. 926. sz.). Első felesége Aranyi Miklós [hunyadi isp.] leánya (1439: Gyulay-Kuún cs 1t, DF 252610, idézi Engel: Gen., Aranyi). 1427-ben Újlaki István familiárisaként részt vett Zsigmond kir. havasalföldi törökellenes hadjáratában, Galambóc ostromában (1428), és ennek jutalmaként megkapta a birtokaiban - Budak (DO), Herepe és Tordas (FH) - levő királyi jogot (1428: DL 30431). 1439-ben elnyerte Albert kir.-tól Budakot (1439: DL 29468); I. Ulászló kir.-tól pedig Léta várát (KL; 1441, 1443: DL 28382, 28387). Ügyvéd, egregius (1441: KmJkv I. 366. sz.), Budakon birtokos (1442: uo. I. 472. sz.). 1433-ban a herepei templomot felkeresők számára bűnbocsánatot kérvényezett a pápánál (1433: Lukcsics II. 235, 290. sz.); udvari lovag (1439: miles aule, Gyulay-Kuún cs 1t, DF 252610; 1439: DL 29468, a felsorolt forrásokat idézi Engel: Arch.
II. 98, 507). Végrendeletében a vásárolt szilvási halastavát és malmát a kolozsmonostori apátságra, szentlászlói jószágrészét az ottani egyházra hagyja. [Torda]szentlászlón (KL) kápolnát építtetett; Léta vár építésére pénzt hagy; magát Kolozsmonostoron akarja eltemettetni; említve létai várnagya (1450: DL 28986). 1450-ben a kolozsvári domonkos kolostortól könyveket vásárol (KmJkv I. 828. sz.). 87

\section{Hermán nemzetség: Felpestesi}

Hesdáti (de Hozdath/Hazdath, DO, KL; Csánki V. 501; Kádár-Tagányi IV. 21)

- Imre, Kolozs vm. szolgabírája (1465-1468). Hesdáton (DO) birtokos (1461: KmJkv I. 1646. sz.), valószínüleg a Kolozs vm.-ben is birtokos frátai Hesdáti család tagja. 76

Hontpázmány nemzetség: Cibak, Esztári, Indali

Horvát (harói, HD; Csánki V. 187)

- Miklós, Hunyad vm. szolgabírája (1496). 59

Horvát (mikeszászi, KK; Csánki V. 935-936)

- Mihály, Küküllő vm. isp. (1513). Mihály és Brigitta fia. Apja Mikeszászán (KK) birtokos (1486: DL 29861). 82

\section{Horvát cs}

- Bertalan, Hunyad vm. isp. (1531). Egregius, I. János kir. familiárisa (1531: Pataki: Hunedoara 259-260). 63

- János, Hunyad vm. isp., Déva vár várnagya (1492). Talán azonos Horvát János lippai és solymosi várnaggyal (1509: TelOkl II. 313). 58

- Kelemen, B-Szolnok vm. isp. (1509). 29

- Péter, Hunyad vm. isp., Hunyad vár várnagya (1544). 64

- Simon, Fehér vm. isp. (1499). 53

Hosdáti (HD; Csánki V. 187) 
- Bálint, Hunyad vm. szolgabírája (1495-1496, 1505, 1507-1508). L. még Bíró (hosdáti)

- Gergely, Hunyad vm. szolgabírája (1510-1516). 61

- János magister, Hunyad vm. szolgabírája (1500, 1509) és jegyzője (1524). 60-62

- Pál, Hunyad vm. szolgabírája (1523). 62

- Vince, Hunyad vm. szolgabírája (1503). 60

hosdáti cs: Bíró, Gálfi, Gergelyfi

Hosszútelki (FH; Iczkovits 56)

- Ferenc, Fehér vm. isp. (1536). 54

- László, Fehér vm. szolgabírája (1451). 52

- Osvát, Fehér vm. szolgabírája (1483). 53

- Zsigmond, Fehér vm. szolgabírája (1525). 54

Huszár (borzafői, de Borzafew; Borzafő nevü település Krassó megyében feküdt; helye nem ismert, a Berzava forrásvidékén, Resicabánya körül kereshetö, 1. Engel: Arch. I. 286; Csánki II. 95)

- Fülöp, Doboka vm. alisp. (1471), B-Szolnok vm. isp. (1471). 28

Iklódi (DO, KL, Borsa nb.; Csánki V. 503-507; Engel: Gen., Borsa nem 3., Iklódi)

- Gergely (Beke fia) magister, Kolozs vm. isp. (1388-1390). 69

- István, Doboka és Kolozs vm. isp. (1465). Péter fia (KmJkv I. 1871. sz.), aki Pénteken (BSz) birtokos (1460: uo. I. 1450. sz.). Ügyvéd (uo. I. 1874. sz.). 1468-ban Doboka vm.-i birtokairól idézik (DL 27498). 1470-ben néhai (DL 107472). 41, 76

- Márton, Doboka vm. isp. (1460, 1465), Kolozs vm. isp. (1465). Beke fia: György fia (1440, 1441: KmJkv I. 203. sz.; Bekefi dictus 1441: uo. I. 378. sz.). Felesége: Drági Zsigmond leánya: Potenciána (1466: KmJkv I. 1688. sz.), gyermekei: János, Tamás és Márta (1466: DL 16446). Iklódon (DO, 1449: uo. I. 672. sz.) birtokos, Poklostelkén (DO, 1466: uo. I. 1690. sz.) jószágrészt vásárolt, Keresztesen (DO, 1454, 1467: uo. I. 1127, 1743. sz.), Örön, Szoporon (KL, uo. I. 1218, 1689. sz.), Dálon, Ugrócon(DO, uo. I. 1664. sz.), Magyardezméren, Oláhdezméren, Szentmiklóson (KL, иo. I. 1903. sz.; TelOkl II. 96-98, 102, 104-105, 111-112), Köblösön és Szótelkén (DO, KmJkv I. 1940. sz.), Kecskeháton (DO, uo. I. 2369. sz.) zálogos jószágrésze volt. Ezeken kívül Vajdaháza, Füzes (DO, uo. I. 1784. sz.), Kecskehát, Köblös és Kékes, illetve a B-Szolnok vm.-i Péntek birtokokban is volt jussa (uo. I. 1763, 1844. sz.). Ügyvéd (1446, 1469: uo. I. 568, 1880. sz.). Csatlakozott Szentgyörgyi János lázadó erd. vajdához, amiért is Mátyás kir. elkobozta birtokait (1467: Ub VI. 293; DL 27330: KL: Szopor és Őr; DO: Iklód, Poklostelke, Vajdaháza, Füzes, Kecskehát, Köblös, Kékes; BSz: Péntek; 1470-1471: DL 26901-26902, 27508-27510: Iklód, Poklostelke, Kecskehát, Köblös. Vö. 1470: DL 27337: Vajdaháza, Füzes, Kékes, Péntek), de neki megkegyelmezett (DL 27339). Vajdai kiküldött (1457: DL 27524). 1473-ban familiárisát említik. †1473. I. 31. e. (KmJkv I. 2078. sz.). 41,76

- Máté, Belsőszolnok vm. szolgabírája (1519). Demeter fia, Iklód, Füzes, Poklostelke (DO), Ör, Szopor (KL) birtokokban volt része (1492: KmJkv II. 2818. sz.). 29

inakfalvi cs: Székely

inaktelki cs: Gyerőfi

Indali (TD; Csánki V. 507-508, 781-782) 
- Gál, Torda vm. szolgabírája (1383). 86

- Pál, Kolozs vm. alisp. (1434-1435), Doboka vm. alisp. (1435). Elírás, miszerint Torda vm. ispánja lett volna (Engel: Arch. I. 251). Torda vm.-i család tagja (más néven peterdi Fancsika; vö. Csánki V. 507-508, 770-771; Engel: Gen., Hontpázmány nem 11. Ugocsai ág 4. tábla: Peterdi), házassága révén Doboka vm.-ben is birtokos. Több alkalommal ügyvéd (1413, 1423, 1431: WassLt 315. sz.; TelOkl I. 467; KmJkv I. 76. sz.; 1421-ben a kolozsmonostori apát ügyvédje, ZsOkl VIII. 1072. sz.), vajdai (1415: uo. V. 327. sz.) és királyi kiküldött (1419: uo. VII. 1131. sz.). Felesége: Gyulai Márta (akitől a jelek szerint Doboka vm.-i birtokokat örökölt a család), gyermekei: Miklós, György (1423: uo. X. 584. sz.), Gergely (1451: KmJkv I. 952. sz.; vö. Csánki V. 497-498) és János (1444: KmJkv I. 488. sz.). 39,74

Ipolt János, Küküllő vm. szolgabírája (1536). 83

iregdi cs: Patócsi

Ispán (kidei, DO)

- Máté (!), Doboka vm. alisp. (1510). 45

- Mátyás, Doboka vm. szolgabírája (1510). Valószínűleg az előbbivel azonos, a két név - Mátyás és Máté szerepeltetése tollhiba. 44

Ispánlaki (FH; Iczkovits 56)

- Benedek, Fehér vm. alisp. (1435), Fehér vm. szolgabírája (1451). 52

ispánlaki cs: Balog

István (Márton fia), B-Szolnok vm. szolgabírája (1370) 1. Szilkeréki István

- (Elleus fia), B-Szolnok vm. alisp. (1349) 1. Torockói István

- comes, B-Szolnok vm. szolgabírája (1325). 25
- (Pető fia) B-Szolnok vm. szolgabírája (1392). Apja, Pető, talán Némai Petővel azonos (1392: TelOkl I. 238). 26

- (Miklós fia) magister, Doboka vm. isp. (1378-1379), Hunyad vm. isp., dévai és hátszegi várnagy (1390) 1 . Aranyi „Porkoláb” István

- comes, Kolozs vm. alszolgabírája (1340). 67

- Küküllő vm. isp., küküllővári alvárnagy (1407). 81

Iwahun magister, Torda vm. isp. (1319). Valószínűleg Balogsemjén nb. Kállai Egyed fiával: Ivánnal azonos személy (Zsoldos Attila szíves szóbeli közlése). A családra lásd Engel: Gen., Balogsemjén nem 1. Kállai 3. tábla: kállói Vitéz). 85

Izbugyai, Zbugyai 1. Ezbwdy

Jakab magister, Torda vm. isp. (1335). Engel (Arch. II. 111) azzal az István fia: Jakabbal azonosítja, akit 1338-ban említenek mint Csicsó vár (BSz) egykori védőjét (CDTrans II. 1013. sz.). 85

Jankafi (ősi, DO; Csánki V. 509-511; Engel: Gen., Jankafi)

- János, Kolozs vm. isp. (1378). Ősi Janka fia $(1359,1379,1383,1397$ : CDTrans III. 1075. sz.; BánfOkl I. 345-346; KmJkv I. 14. sz.; ZsOkl I. 5031. sz.). Ivánka, Péter, Simon, László és György apja (Engel: i.m.; 1402, 1404: TTár 1907. 90. = DF 280914, 244536). Ôs (DO), Palatka, Petelaka és Légen (KL) birtokosa (1373, 1377, 1379: DRH. C. XIV. 359; uo. XV. 189-190; BánfOkl I. 345-346; WassLt 173. sz.). 69

Jánoktelki/Jánoki (BSz; Jánoktelke/Jánok = ismeretlen fekvésü település)

- Péter fia: Antal, B-Szolnok vm. szolgabírája (1405-1406, 1408). 26

János deák (litteratus), Doboka vm. jegyzője (notarius sedis, 1512). 45 
- deák, Hunyad vm. jegyzője (1529-1531). 63

- (Demeter fia), Doboka vm. szolgabírája (1350-1361) l. Galaci János

- (Márton fia), Doboka vm. szolgabírája (1315), Doboka vm. isp. (1321-1334) 1. Mórici János

- (Miklós fia), Hunyad vm. isp. (1382-1390), dévai várnagy (1382-1390), hátszegi várnagy (1390) 1. Aranyi János

- magister, Hunyad vm. isp., dévai várnagy (1397). 56

- (Gegus fia), Kolozs vm. isp. (1355) 1. Apafi János

- magister, besztercei, kolozsi és kolozsvári ispán (1317) l. Fonói János

- (Mihály fia), Kolozs vm. szolgabírája (1360-1361). A birtoknév nélkül említett Mihály fia: János azonosítására két lehetőség van: 1. Györgyfalvi Mihály fia: János (1350: CDTrans III. 572. sz.). Olah (d) György fia: Mihály fia (1371: TelOkl I. 169-170), Györgyfalva (KL) birtokosa (1366: DRH. C. XIII. 168). Királyi kiküldött (1377: DRH. C. XIV. 181). 2. Tuzsoni Semjén fia: Mihály fia: János (1348: CDTrans III. 459. sz.; 1. még: Engel: Gen., Tuzsoni [Szentkirályi]). 68

Jánosdi $(\mathrm{BH})$

- (dictus de Janosdi) Domokos, Doboka vm. alisp. (1415). Csáki Miklós erd. vajda és bihari ispán (Engel: Arch. I. 113) familiárisa. 36

Járai (TD; Engel: Gen., Zicsi/Zichy; Csánki V. 671)

- Gál magister (Pascha fia), Kolozs vm. isp. (1353), B-Szolnok vm. isp. (1355). Azonosítására lásd CDTrans III. 58, 449. sz. (1341, 1348). Járai; János apja, aki Szentmárton (TD) birtokosa és Gerendi Miklós fia: Miklós rokona (1362: DRH. C. XII. 58-59). A Zichy cs őse; valószínűleg ő építtette Jára várát/Bélavárat (TD, Engel: Arch. II. 332. Lásd még: Csánki V. 671). 25, 68

Járai (TD; Csánki V. 783-786)

- Domokos (Marcellus fia), Torda vm. szolgabírája (1310). 85

- György (Jakab fia), magister, Kolozs vm. isp. (1358-1359). Olykor Csáni György névvel említik. Azonosítására lásd CDTrans III. 61, 785, 830. sz. (1341, 1355, 1356; téves azonosítása: EM 1902. 245). 1344-ben vajdai közgyülésen ülnök (uo. III. 227. sz., ahol Csáni Györgyként szerepel); comes: uo. (1351: uo. III. 600. sz.). Torda vm.ben birtokos (1341: uo. III. 61. sz.). Pecsétje: TelOkl I. 111. 68

- László (Dénes fia), Torda vm. szolgabírája (1335, 1338 e.). Tótháza (KL; 1334: CDTrans II. 829. sz., kétes hitelü okl.) és Benk (TD; иo. III. 52, 89. sz.) birtokosa. 85

- Miklós (Tamás fia), Kolozs vm. szolgabírája (1358-1359). Tamás fia: Miklós minden bizonnyal Kolozs vm.-ben birtokos; talán azonos azzal a Járai Tamás fiával: Miklóssal, akit 1356-ban egy Doboka vm.-i egyezség kapcsán említenek (CDTrans III. 830. sz.) és aki fogott bíró Belsőszolnok vm.-ben (1380: TelOkl I. 193). 68

- Miklós, Torda vm. isp. (1461). Ügyvéd (1459: KmJkv I. 1393. sz.). 88

Járai Péter 1. Váradjai

jegyzők: Antal deák (Fehér és Küküllő vm., 1438); Kidei Damján magister (Doboka vm., 1546); Kisdevecseri Fábián (Doboka vm., 1520-1525); János deák (Doboka vm., 1512); János deák (Hunyad vm., 1529-1531); Miklós deák (Kolozs vm., 1524-1530); Sebestyén (Doboka vm., 1516); Szucsáki Miklós magister (Doboka vm., 1530); Újfalusi Lukács deák (Doboka vm., 1494-1495). 
Kabos (gyerőmonostori, KL; Csánki V. 512-517; Engel: Gen., Mikola rokonsága 5. tábla: Radó és gyerőmonostori Kabos)

- Péter, Doboka vm. alisp. (1452). Talán azonos az 1419-ben említett gyerőmonostori Kabos fiával: Péterrel (Engel: Gen.; 1419: ZsOkl VII. 270. sz.). Ilona (1439: KmJkv I. 108. sz.), majd cegei Wass Potenciána férje (1449: uo. I. 706. sz., WassLt 43). Tamás, János és Mihály apja (1441: KmJkv I. 303. sz.). Deritén (uo. II. 451. sz.), Berenden és Szentmiklóson birtokos, része volt a Gyerőmonostoron szedett vámban (KL, 1423: ZsOkl X. 45. sz.). Ügyvéd (KmJkv I. 136, 405, 611, 707, 917, 1025. sz.). 1442-ben Kolozs vm.-i birtokperben döntőbíró (ekkor - mások mellett - váraskeszi Lépes Loránd volt erd. alvajda társa, uo. I. 435. sz.; 1. még: uo. I. 836. sz.). 40

Kabos Mihály, Hunyad vm. isp. (1531). Egregius, I. János kir. familiárisa (1531: Pataki: Hunedoara 259-260). 63

\section{Kacsics nem: Zagyvafői}

Kakas (kazai, BSD; pásztói, HS; Rátót nb.; Csánki I. 161; Engel: Gen., Rátót nem, 5. tábla: Kakas, kazai)

- (Kakas d) Gyula, Hunyad vm. isp., hátszegi várnagy (1413). László fia (1427: DL 89879). Udvari lovag (1406-1426, Engel: Arch. I. 497). Pásztón (HS) jószágrészt vesz zálogba (1427: DL 89879). 1428-ban néhai (DL 89887; a forrásokat idézi: Engel: i. m.). 56

Kállói ([semjéni] SzB; Balogsemjén nb.; Csánki I. 535-536; Engel: Gen., Balogsemjén nem 1 . Kállai, 1. tábla: semjéni ág)

- Ubul (v. Tamás; László fia, semjéni) magister, Lackfi Dénes erd. vajda, majd Lackfi István többi fiának familiárisa, Újvár várnagya, Küküllő vm. isp. (1361), Sebesvár (KL) várnagya (1364),
Szatmár vm. (al)isp. (1364-1367), Arad vm. alisp. (1368-1372), Vas vm. alisp. (1379). 1348-1350-ben Lackfi István erd. vajda oldalán Nápolyban harcolt; 1379-ben a velenceiek ellen harcolt Itáliában. Feleségei: keszi Rátóti János leánya: Orsolya és Kelneki Magdolna. (Lásd Engel: Arch. II. 121; Engel: Honor, vár, ispánság. In: Századok 116/1982. 5. sz. 895-896; uő: A török-magyar küzdelmek legrégibb fejezete? Egy magyar lovag levele Rodoszról 1361-ből. In: Szomszédok között Kelet-Európában. Emlékkönyv Niederhauser Emil 70. születésnapjára. Bp. 1993. 36-37). 81

Kályáni ([kályáni], KL; Csánki V. 519520)

- Mihály (Dénes fia), magister, Kolozs vm. isp. (1398). Mihály apja (1412: TelOkl I. 388). Eml.: DL 28769, keltezés nélkül. 70

Kán nb. Gyula, erd. vajda és Fehér vm. isp. (1201). Erdélyi vajda (1214) és szolnoki isp. (1214), szolnoki isp. (1214, 1220-1221); további tisztségeire lásd Zsoldos: Archontológia 305-306; Kristó Gy.: Kán László és Erdély. Tanulmányok az Árpád-korról. Bp. 1986. 276-277. 49

Kaplyon nemzetség: Károlyi

Karászi Sándor (Drugh fia) bán, Doboka vm. isp. (1274). Egyidejüleg szebeni isp. (Alexander banus comes de Scybinyo et de Doboka, 1274. VIII. 27.: DL 41578. = CDTrans I. 331); 1274. [XII. 25-30.] (RegArp II/2-3. 2566. Sz.). Szebeni isp. (Alexius comes de Scibinio, 1272. IV. 26.: uo. II/2-3. 2492. sz. = CDHung V/2. 172); csak szebeni ispánkén: [1274?] XI. 1. (CDTrans I. 332. sz.). István ifjabb kir. híve, több hadjáratában részt vett (Zsoldos A.: Karászi Sándor bán és utódai. In: Századok 135/2001. 2. sz. 387, 389). Birtokai 
Borsod, Szatmár, Zemplén, Szabolcs és Heves vm.-ben feküdtek (Zsoldos: i. m. 389-390). 118

Károly (szentmiklósi, DO; Szentmiklós = Áronszentmiklós; a család azonos vagy rokon az ugyancsak Áronszentmiklóson birtokos Szentmiklósi családdal, 1. ott is)

- István, Doboka vm. isp. (1456-1457). Áronszentmiklóson (DO) birtokos család tagja (KmJkv II. 3040. sz.). Alvajdai kiküldött (1455: WassLt 451. sz.). 41

- László, Doboka vm. isp. (1453). Áronszentmiklóson birtokos család tagja (KmJkv II. 3040. sz.; 1452: DL 29493, idézi Kádár-Tagányi II. 51), vajdai kiküldött (1480: DL 27540; 1482: TelOkl II. 152-153, 159). 41

Károlyi (de Karol; SzR; Kaplyon nb.; Engel: Gen., Kaplyon nem, 1. tábla: Károlyi)

- Lanch [= László], Kolozs vm. isp. (1431). Károlyi Mihály fia: László (1394: KárOkl I. 470; gyermek: 1395: uo. I. 471). Károlyi Mihály fia: Lancz; felesége: Henchidai Mihály fia: László leánya, Gyapoli Péter özvegye (1436: uo. II. 183-184). 1447-ben néhai (uo. II. 253; a felsorolt forrásokat idézi Engel: Gen.). 40

kazai cs: Kakas

Káta nemzetség: Dengelegi

kecseti cs: Székely

Kecseti (Kechethy, TD; Csánki V. 786787)

- Balázs, Torda vm. isp. (1530-1536). Egregius (1524: KmJkv II. 4007. sz.). 1530-ban somlyói Bátori Istvántól megkapja petlendi Egresi Kelemen és fia: Tamás birtokait (1530: MOL, Erdélyi iratok, 1527-1938, R 298, Vegyes erdélyi iratok, 9. d, Évrendezett iratok, 1527-1600). Gyéresen (TD) volt udvarháza; János apja; 1555-ben néhai (KmJkv II. 5367. sz.). 90

Kegye (Kege dictus; mikói; DO)

- Miklós, Doboka vm. alisp. (1415-1416, 1426-1428). Mikó (DO, elnéptelenedett település Hídalmás és Drág között) birtokosa. Vajdai ember (1428: WassLt 384. sz.). 36

Kéméndi (HD; Csánki V. 188-189)

- István, Hunyad vm. szolgabírája (1496). 59

- Miklós; Hunyad vm. szolgabírájával: $\rightarrow$ Kisbarcsai Mihállyal együtt bocsát ki oklevelet (1520: Jósika cs hitb. lt, DF 257630). 62

- Pál, Hunyad vm. szolgabírája (1467). 57

- Péter, Hunyad vm. alisp. (1467). Királyi ember (1468: DL 27499). 57

- Simon (Gergely fia), Hunyad vm. szolgabírája (1433). 56

Kemény (de Kemen, gyerőmonostori; KL; Csánki V. 512-517; Engel: Gen., Mikola rokonsága, 6. tábla: Kemény, gyerőmonostori)

- Péter, Kolozs vm. szolgabírája (1493), Kolozs vm. isp. (1510-1516, 1521, 1528). Gyerőmonostori Kemény István [erd. alvajda] fia (1460: KmJkv I. 1483. sz.). Berenden, Gyerőmonostoron (KL) birtokos (1467, 1493: иo. I. 1767. sz., II. 2873. sz.). Egregius (1522, 1525: uo. II. 3845, 4065. sz.). 1531-ben néhai; gyermekei: János, Péter, László, Ferenc, Imre (1531: uo. II. 4350. sz.; vö. Csánki V. 513). 78, 80

- Péter, Fehér vm. isp. (1533). 54

Kendhidai Balad 1. Baládfi

Kendi (DO; Csánki V. 521-522)

- Antal, Doboka vm. isp. (1540). Fejedelmi tanácsúr (1542-1551, 1556-1558). Izabella királyné 1558-ban megöleti (Trócsányi Zs.: Erdély központi kormányzata 1540-1690. Bp. 1980. 29, 106, 
257. jegyz.). Bogáti Klára (1553: KmJkv II. 5205. sz.), majd Jaksics Anna férje (1555: uo. II. 5435. sz.). Szentiván, Pulyon, Császári, Cege (DO, 1502, 1506, 1507: WassLt 509, 532, 537. sz.), továbbá Fodorháza, Szentkatolna, Szótelke, Ugróc (DO) birtokokban volt jószágrésze; egregius (1555: KmJkv II. 5392. sz.). Szótelkén jószágrészt vett zálogba (1534: uo. II. 4485. sz.), Oláhdellőn (TD) jobbágytelkeket vásárolt (1549: uo. II. 4924. sz.). 47

- Gál, Doboka vm. isp. (1513-1524). Antal [erd. alvajda (1477-1479)] fia (1493: WassLt 482. sz.), Ferenc apja (KmJkv II. 4672. sz.). 1506-ban alsótőki (DO) jószágrészét - gyermekei: Ferenc, Eufrozina és Klára nevében is - elcserélte Tőki Imre lónai jószágrészéért és ottani kúriájáért (1506: DL 30512). Császáriban jószágrészt vásárolt (WassLt 537. sz.), Szentiványon (1502: uo. 509. sz.), Pulyonban (uo. 532-533. sz.), Cegén (uo. 537. sz.), Szentgothárdon (DO) birtokos; ezek a jelek szerint a Györgyfalviaktól örökségként jutottak hozzá (uo. 545. sz.). Fogott bíró (1507: TelOkl II. 298). 45

- Gergely, Doboka vm. szolgabírája (1392-1397, 1408 e.). Alvajdai kiküldött (1393: ArhIstRom 2/2004. 2. sz. 22. $=$ DL 27440/1). 35

- Mihály, B-Szolnok vm. isp. (1539). Eml.: KmJkv II. 5245. sz. (1553). Katalin férje, Katalin és Farkas apja (1554: uo. II. 5304. sz.). Egregius, Fodorháza, Szentkatolna, Szótelke, Ugróc (DO) birtokosa (1555: uo. II. 5392. sz.). 29

- Tamás (Raphael fia), Doboka vm. szolgabírája (1369-1372). Kendi (1372: WassLt 159. sz.). Alvajdai ember (1371: TelOkl I. 168). 34

kerelői cs: Erdély, Tatár

Kerelői János 1. Erdély János
Keresztesi (DO; Keresztes = elnéptelenedett település Nagyiklód határában)

- Mihály (Kaza fia), Doboka vm. szolgabírája (1305). Fia 1354-ben Keresztes birtokosa (DO; CDTrans III. 743. sz.). 32

Keresztesi (szentiványi, BSz; Szentivány = Iklódszentivány)

- Antal, B-Szolnok vm. szolgabírája (1482-1483). 1500-ban néhai; ekkor gyermekei - Mátyás, Domokos és Zsófia - a keresztesi (DO, elnéptelenedett település Iklódszentivány közelében) jószágrészüket elidegenítik (KmJkv II. 3145. sz.) 28

Keresztúri (HD; Csánki V. 194; Keresztúr = Csernakeresztúr)

- Kelemen, Hunyad vm. szolgabírája (1488). Királyi kiküldött (1506: DL 29914). 58

- Péter (Pál fia), Hunyad vm. szolgabírája (1333). 55

Keresztúri (TD; Csánki V. 714; Keresztúr $=$ Gerendkeresztúr)

- László deák, Torda vm. szolgabírája (1436-1440). Ügyvéd (1441, 1445, 1448, 1452: KmJkv I. 338, 546, 627, 1043. sz.). 86-87

keresztúri cs-ok: Furka, Veres

Kidei [?] (de Kege; DO [?]; Kegyei [?], Csánki I. 477, KSz [?])

- Péter, Doboka vm. szolgabírája (1379). 34

Kidei (csomafáji, DO)

- János, Doboka vm. alisp. (1495-1496). 44

Kidei (DO; Csánki V. 523)

- András, Doboka vm. szolgabírája (1420). Miklós apja; Kidén birtokos (1469: KmJkv I. 1879. sz.). Talán Andreas Mony de Kyde-vel azonos (ügyvéd: 1415: TelOkl I. 419). Alvajdai kikül- 
dött (1423: ZsOkl X. 584. sz.; 1434: DL 27295). 37

- Damján magister, Doboka vm. nótáriusa (1546). 47

- Frank, Doboka vm. szolgabírája (1470-1473). Kidén birtokos (1454: KmJkv I. 1174. sz.). Felesége: kidei Bíró András leánya: Erzsébet. Gyermekei: Mátyás és Gergely (1454, 1482: uo. I. 1174, 2400. sz.). Olykor Ferencként említik (1482: uo. I. 2400. sz.). Királyi ember (1456: DL 27482), vajdai kiküldött (1479: DL 27535). 42

- István, Doboka vm. szolgabírája (1439). 1415-ben vajdai kiküldött (ZsOkl V. 327. sz.). Ügyvéd (1440, 1441: KmJkv I. 199, 346. sz.). 39

- János (Inok fia), Doboka vm. szolgabírája (1361-1364). Kidén (DO) birtokos (1362: DRH. C. XII. 114-115). Pecsétje: TelOkl I. 132 (1364). 33-34

- Frank Gergely, Doboka vm. szolgabírája (1493). Vajdai ember (1496, 1499, 1500, 1509, 1511: DL 27568, 27576, 27578, 27517, WassLt 568. sz.). Neve alapján bizonyára Frank fia. 44

kidei cs: Egyed, Fegyveres, Récsei

Kis (Parvus; esztényi, DO)

- Tamás, Doboka vm. alisp. (1481). 43

Kis (Parvus; feldevecseri, DO)

- István, Doboka vm. szolgabírája (1449-1452). Alvajdai kiküldött (1455: WassLt 451. sz.). 40

Kis (Parvus; harói, HD)

- Bálint, Hunyad vm. szolgabírája (1488, 1508). 58, 61

Kis (Parvus, makrai, de Mackra; BSz?)

- Tamás, B-Szolnok vm. isp. (1474). Talán a B-Szolnok vm.-i Szentgyörgyön (= Vízszentgyörgy, puszta Széplak közelében) birtokos Makrai cs tagja (Kádár-Tagányi VII. 114). 28

Kis (Parvus)

- Lőrinc, Hunyad vm. alisp. (1410). 56
Kis (Parous; szőkefalvi, KK; Csánki V. 939)

- Illés, Küküllő vm. szolgabírája (1499-1513). Vajdai (1503, 1504, 1507: DL 29905, 27784, 28558) és nádori ember (1507: Veress: Acta et epistolae IV. 88$) .82$

- Illés, Küküllő vm. szolgabírája (1532). 82

Kis (Parvus; tőki, DO)

- Mihály vagy tőki Konc Mihály, Doboka vm. szolgabírája (1415). Vajdai kiküldött (1415: ZsOkl V. 327. sz.). 36-37

Kis (Parvus; újbudai, KL; Csánki V. 446-452, Budai név alatt). Lásd még Budai

- Gergely, Kolozs vm. szolgabírája (1429-1434). Domokos apja (1455: KmJkv I. 197. sz.) 73-74

Kis, Parvus (sárdi) Antal, Doboka vm. alisp. (1510) 1. Sárdi (Kis) Antal

Kisbarcsai (HD; Csánki V. 196). L. még Barcsai cs

- Mihály, Hunyad vm. szolgabírája (1516-1520), alisp. (1524). 61-62

kisdevecseri cs: Balai

Kisdevecseri (DO)

- Fábián magister, Doboka vm. jegyzője (1520-1525). Kisdevecseri (1520: Bánffy cs nemz. lt, DF 261121; 1522: WassLt 633. sz.). Alvajdai ember (1522: uo. 633. sz.). Kisdevecseri Simon apja (1550: KmJkv II. 5019. sz.). 46

Kisenyedi (FH; Iczkovits 57)

- János, Fehér vm. szolgabírája (1510). 53

kisesküllői cs: Székely

kisfaludi cs: Bordi

kiskapusi cs: Gyerőfi

kistárkányi cs: Boda

Kyzeleczky 1. Cseszelicki

Kobza (Kobza) 
- Ferenc, Torda vm. szolgabírája (1536). 90

Kodori (BSz; az olasz eredetű Manini család leszármazottai; Draskóczy I.: Olaszok a 15. századi Erdélyben. In: Scripta manent. Ünnepi tanulmányok a 60. életévét betöltött Gerics József professzor tiszteletére. Bp. 1994. 131)

- András, B-Szolnok vm. szolgabírája (1476, 1484-1485). Kodori Pape fia, ügyvéd (1473: KmJkv I. 2083. sz.). Ferenc és Jakab apja, 1491-ben néhai. Családja birtokai: Kecset (DO), Kodor, Törpény, Keménye, Alsó- és Felsőgyékényes, Péterháza (BSz, 1491: uo. II. 2719. sz.). 28-29

kolozsvári cs: Sertő

Komjátszegi (elekesi, FH)

- István, Fehér vm. szolgabírája (1515). 53

Komjátszegi (TD; Csánki V. 527, 790)

- Imre, Torda vm. szolgabírája (1401-1408). 86

- István, Torda vm. szolgabírája (1536). Felesége: Budai Tamás leánya: Margit (KL, 1537: KmJkv II. 4606. sz.). Komjátszegen és Szentmártonon (TD) birtokos (1528, 1537: uo. II. 4207, 4607. sz.). 90

- János, Torda vm. szolgabírája (1484). Komjátszegen és Baromlakán birtokos (TD; 1482: KmJkv II. 2358. sz.). Ügyvéd (1482: uo. II. 2357. sz.). 89

- Miklós, Torda vm. szolgabírája (1409-1418). Oláhfrátán (KL) is birtokos (1402: ZsOkl II/1. 1593. sz.). Alvajdai, királyi és vajdai ember (1401, 1412, 1420: TelOkl I. 281, 383; ZsOkl VII. 1729. sz.) 86

- Miklós, Kolozs vm. szolgabírája (1429). Lehet, hogy azonos a fentebbivel. 73

Konc Mihály 1. Kis (tőki) Mihály

Kónya (alpestesi, HD; Csánki V. 197)
- János, Hunyad vm. szolgabírája (1507). 60

Korógyi [?] Fülöp, Doboka vm. isp. (1272) 1. Fülöp

Korógyi (v. Koródi; KK; Csánki V. 940)

- András, Küküllő vm. szolgabírája (1478-1479). Királyi ember (1473: DL 30323). 82

Korpádi (KL; Csánki V. 528)

- „Bogár (Bugar d)” János, Kolozs vm. szolgabírája (1351). Korpádi (KL); Márton fia: Beke fia (1345: CDTrans III. 280. sz.); Korpádi „Bogár” János. Korpádon birtokos (1357: uo. III. 879. sz.). Patán (KL) birtokot vásárol (1344: uo. III. 204. sz.). Alvajdai ember (1352, 1356: uo. III. 643, 676, 845. sZ.; 1366: DL 30105). 67

- András 1. Fodorházi András

\section{Kozárvári (BSz)}

- László deák, [Belső]szolnok vm. isp. (1536). 1520-ban Szolnoki László néven második férje losonci Bánffy István leánya: Bánffy Katalinnak, 1525 u. nevezi magát Kozárvárinak. 1539-ben részt vett a Majlád-féle titkos szervezkedésben (BánfOkl II. 497, 501, 537; Középkori leveleink /1541-ig/. Szerk. Hegedűs A. és Papp L. Bp. 1991. 474-475; 1536. VII. 29. u., ENMLt, Bánffy cs nemzetségi lt, középkori okl. 610. sz.). Gyermekei: György, Ferenc, János, Zsófia és Anna (1547: MOL, Gyulafehérvári Káptalan Országos Levéltára, F3, Centuriae, A 36). Litteratus (ENMLt, Suky cs lt, 1535. III. 7., középkori okl. 194. sz.). Bánffy Istvántól zálogba kapta Gledény, Kisgledény (KL) és Oroszfalu (TD) birtokokat (1528. VI. 14.: ENMLt, Bánffy cs nemzetségi lt, középkori okl. 578. sz.). 29

Kökényesradnót nemzetség: Bogáti, Dobokai 
Kömörői (de Kemere; SzR; Csánki I. 496; a Szentemagócs nb. Kölcsei cs egyik ága, 1. Engel: Arch. II. 135)

- János, Kolozs vm. isp. (1431), Szatmár vm. alisp. 1440-ben (Engel: Arch. I. 191). Szatmár vm.-ben birtokos (1438: DL 68060). 74

Körei (de Kere, HS; Csánki I. 65)

- Kristóf, Hunyad vm. isp. (1468-1469). 1474-ben dengelegi Pongrác János lippai várnagya (DL 17660). 57

Körtvélyesi (de Kertheweles; KSz?; Csánki I. 559)

- György, Doboka vm. isp. (1473). 42

Köte (Kethe; [kötegyáni, remetei]; $\mathrm{BI}$ )

- János, Torda vm. isp. (1430-1436); Csáki László (1426-1437) erd. vajda familiárisa. Zaránd vm. követe (1440), országgyűlési követ 1444-ben (Engel: Arch. II. 519). 86

kövesdi cs: Tomori

középlaki cs: Bikali

Kristóf, Kolozs vm. isp. (1213), Szolnok vm. isp. (1215: CDTrans I. 77. sz.; Zsoldos: Archontológia 163, 210, 320). 65

Kucsor ([?] Cuchor) 1. Cucor

László (Myke fia), B-Szolnok vm. szolgabírája 1. Tötöri László

Laki György, Hunyad vm. alisp., Hunyad vár várnagya (1477), [1481 u.] Atyina (Körös vm.) várnagya 3 évig (1495: Jajcza 128; az adatot Horváth Richárdnak köszönöm). 57

Lapádi (Demjén nb.-i; FH; Iczkovits 58; Györffy II. 171)

- Péter magister (Bökény/Buken fia), Fehér vm. szolgabírája (1320). Demjén (HS) birtokosa, melyet elcserél Lapádra (1316, 1317: CDTrans II. 262, 277. sz.). Demjén nb. (uo. II. 277. sz.). 50

László (Márk fia), B-Szolnok vm. isp. (1392) 1. Szavai László
- magister (Miklós fia), Hunyad vm. isp., dévai várnagy (1395) 1. Zagyvafôi László

- magister (László fia), Kolozs vm. isp. (1366) 1. Nádasi László

- (Barabás fia) Küküllő vm. szolgabírája (1361) 1. Szentpáli László

- (Dénes fia), Torda vm. szolgabírája (1335) 1. Járai László

Lépes (váraskeszi, ZD; Csánki I. 752, V. 941; Engel: Gen., Treutel-rokonság, 2. tábla: Lépes, váraskeszi)

- Loránd, Küküllő vm. isp. (1434), erd. alvajda, Fehér vm. isp. (1415-1438). Miklós-fi Loránd fia, Zaránd vm.-i cs tagja. Tamási János erd. vajda (1403-1409) és ajtónállómester (1409-1416) familiárisa, szolnoki alisp. (1407), királyi alajtónállómester (1414-1415), udvari familiáris (1414). Csáki Miklós (1415-1426) és Csáki László (1426-1437) erd. vajdák familiárisaként erd. alvajda (1415-1438) és Küküllő vm. isp. (1434). Hunyadi János erd. vajda (1441-1446) familiárisaként erd. vajdai kormányzó (1444-1445). Lásd Engel: Arch. II. 145. A Lépes családnak Küküllő vm.-i birtoklásáról a 15. század közepéről vannak adatok (Csánki V. 941). 51

Lesták (Eustachius), Doboka vm. isp. (1165-1166 k.), Rátót nb. [?] (Engel: Gen., Rátót nem, 1. tábla: elágazás; Karácsonyi: Nemzetségek 912). Talán azonos azzal a Leustachius erd. vajdával, aki 1176-ban III. Béla király segédcsapatait vezette, melyeket utóbbi I. Manuel bizánci császár megsegítésére küldött (CDTrans I. 12. sz. [1176-1196]). 31

Lógó (alpestesi, HD; Csánki V. 150 [Alpestesi cs], 203)

- Máté, Hunyad vm. szolgabírája (1477-1483). 57-58

Lónai $(\mathrm{DO} ;$ Lóna $=$ Kendilóna $)$ 
- Caplon/Coplon, Doboka vm. szolgabírája (1331). Lónai Péter fia, testvérei: János, Fyntha, Mihály (1315: CDTrans II. 252-253, 258. sz.). Miklós apja (1369: DRH. C. XIII. 653). Doboka, Lozsád, Maró és Jenő (DO) szomszédja (1348: CDTrans III. 461. sz.). 33

- Demeter comes, Doboka vm. szolgabírája (1364-1367). Imre apja (1369: DRH. C. XIII. 653). Alvajdai és vajdai kiküldött (1357, 1361: CDTrans III. 890. sz.; DRH. C. XII. 36). Lónán kúriája volt. † 1395. II. 1. e. (ArhIstRom 2/2004. 21-22. = DL 27440/1). 34

Lorand (Artolph/Ortalph fia), Doboka vm. szolgabírája (1315) 1. Szentpáli Lorand

losonci cs: 1. Dezsőfi

Lozsádi (HD; Csánki V. 203)

- Bereck fia: Benedek (Benedictus Brictii), Hunyad vm. szolgabírája (1468-1469). 57

Lozsádi (HD?; Csánki V. 203)

- István, Fehér vm. alisp. (1478). 52

Lökös (héderfájai, KK; Csánki V. 942)

- Domokos, Küküllő vm. szolgabírája (1448). 82

Lőrinc, Doboka vm. isp. (1270-1272), egyidejűleg szörényi bán (1270, 1271-1272). Kemény fia (1267: RegArp II/1. 1869. sz.). További tisztségeire lásd Zsoldos: Archontológia 324. 32

Lukai (Lwkay)

- Bernát, Torda vm. isp. (1493). 89

Macskási (bakaji, HD; Csánki V. 204)

- Gáspár; Hunyad vm. szolgabírájával: $\rightarrow$ Kisbarcsai Mihállyal együtt bocsát ki oklevelet (1520: Jósika cs hitb. lt, DF 257630). 1523-ban vajdai kiküldött (DL 31039). 62

Macskási (DO, KL; Csánki V. 544-545)

- Damján, Doboka vm. szolgabírája (1513-1516). Szentkeresztmacskáson (DO, eltünt település Macskás környé- kén) birtokos. János apja. †1527. V. 17.

e. (KmJkv II. 4189. sz.). 45

- Darabos Mihály, Doboka vm. szolgabírája (1378). Diósmacskáson (DO, Csánki V. 377) birtokos (1357: DRH. C. XI. 174). Alvajdai ember (1357, 1367, 1371: WassLt 112. sz.; TelOkl I. 155; uo. I. 170). 34

- János (Márton fia), Doboka vm. szolgabírája (1390). Diósmacskáson birtokos (1358: DRH. C. XI. 265-266), alvajdai (1365: uo. XII. 403; 1371: TelOkl I. 167) és királyi kiküldött (1395: ArhIstRom 2/2004. 23. = DL 27441). 35

- Péter, Kolozs vm. szolgabírája (1410, 1422-1424, 1425, 1429). A kolozsmonostori apát Kajántó nevű birtoka felőli határperrel kapcsolatosan említik, Macskáson (KL) birtokos (1417, 1418: ZsOkl VI. 20, 1404, 2113. sz.). Királyi és alvajdai kiküldött (1421: uo. VIII. 1238. sz.; 1427: TelOkl I. 496). Egy 1422. IX. 30-i oklevélben (uo. I. 462) tévesen szerepel Doboka vm. neve, ez valójában Kolozs vm. kiadványa és Mócsi Macskási Péter ennek a vm.-nek a szolgabírája. 71-73

macskási cs: Almádi

Magnus 1. Nagy

Magyi (de Magh, SzB) Pál [Dömötör fia, PerényiLt 489. sz.], Hunyad vm. isp., Déva vár várnagya (1492). Valószínüleg azonos azzal a Magh-i Pállal, aki alországbíró és alvajda (alországbíró: 1501: DL 71079; mindkettő: 1502: DL 62961; 1502: PerényiLt 700. sz.; 1503: WassLt 518. sz.; 1511: DL 32581), alnádor (1504: PerényiLt 715. sz.; 1505: DL 39335; vö. Bónis Gy.: A jogtudó értelmiség a Mohács előtti Magyarországon. Bp. 1971. 356-357). 58

Makrai (szentgyörgyi, BSz; Szentgyörgy = Vizszentgyörgy)

- Bertalan, B-Szolnok vm. isp. 29

makrai cs: Kis 
mányiki cs: Erdős, Sztrigyi

Margai (de Marga; Szörényi bánság?)

- László, Torda vm. isp. (1461). 88

Marói [esztényi, DO; Kádár-Tagányi V. 138]

- Lőrinc, Doboka vm. szolgabírája (1487). Esztényi (1470: KmJkv I. 1994. sz.). Dobokán, Lozsádon (1475: uo. I. 2195. sz.) és Marón birtokos (1473: DL 27347, Kádár-Tagányi V. 139). 1475-ben Marói Lőrincet - továbbá Albertet, Andrást, Pált és Zsigmondot - beiktatták Maró birtokbeli részeikbe, amelyeket őseik régtől fogva békésen birtokoltak, királyi adomány címén (1475: DL 27525-27526). Ügyvéd (1470: KmJkv I. 1994. sz.), vajdai kiküldött (L. de Mara, 1466, 1470, 1482: DL 27327, 27336, 27528, 27370). 1468-ban tanúként idézik egy Doboka vm.-i perben (DL 27498). 43

marói cs: Székely

Márkházi Péter (Gál fia), Doboka vm. szolgabírája (1384, [1384-1392?]) 1. Frátai Péter (Gál fia)

Marót magister, Torda vm. isp. (1350) 1. Cine Marót

Márton [Máté fia], Hunyad vm. isp. (1333), dévai várnagy (1326-1338) 1. Mátéházi Márton

Mátéházi (GM)

- Márton (Máté fia), Hunyad vm. isp. (1333), dévai várnagy (1326-1338; azonosítására lásd DL 86571. = AOkl X. 321. sz.; idézi Engel: Arch. I. 248; vö. EM 67/2005. 3-4. sz. 81). 55

Mátyás deák, (al)vajdai jegyző, Fehér vm. alisp. (1398). 51

Medvés (szentmártoni, DO; Szentmárton = Szépkenyerüszentmárton [?])

- Antal, Doboka vm. alisp. (1431-1434), B-Szolnok vm. alisp. (1434-1435). 27

Meggyesfalvi Jakab („Alárd fia”), Torda vm. isp. (1440) 1. Alárdfi Jakab
Méhesi (TD)

- Balázs, Torda vm. alisp. (1440). Vélhetôleg a Torda vm.-i méhesi Gyerőfi (v. Méhesi) család (1. Csánki V. 777) tagja. 87

méhesi cs: Tót

Méhesi [?] [KL?]

- Miklós comes (Gyerő fia), Doboka vm. isp. (1341). Nem tagja a szamosfalvi Mikola családnak (Engel: Gen., Mikola rokonsága 2. tábla; Gyerőfi; Engel: Arch. I. 246, 395. sz. jegyz.). Talán azonos azzal a Gereu fia: Miklóssal, aki Gyekén (KL) birtokos (1335: CDTrans II. 862. sz.). László apja (1363: DRH. C. XII. 160). 33

Mérai (KL; Csánki V. 550-552)

- Bálint, Kolozs vm. szolgabírája (1389). 69

- Miklós, Kolozs vm. isp. (1334). Domokos, László, Miklós, Kelemen, Jakab deák és Ilona apja (1334, 1348, 1354: CDTrans II. 796, III. 468, 485, 755. sz.). Koródon (KL) jószágrészt vásárolt (1334: uo. III. 797. sz.). Királyi kiküldött (1326, 1332, 1334: uo. III. 571, 760, 806. sz.). 1344-ben vajdai közgyülésen Kolozs vm.-ből választott esküdt ülnök (uo. III. 227. sz.). 66

Mercurius, Fehér vm. isp. (1097), erd. vajda (1111-1113; Diplomata Hungariae antiquissima, accedunt epistolae et acta ad historiam Hungariae pertinentia. Ab anno 1000 usque ad annum 1196. I. /1000-1131/. Edendo operi praefuit Georgius Györffy, adiuverunt Johannes Bapt. Borsa, Franciscus L. Hervay, Bernardus L. Kumorovitz et Julius Moravcsik. Budapestini 1992. 383, 396. Lásd Zsoldos: Archontológia 36, 151, 329). 49

mezőcsáni cs: Csáni

Mezőcsáni László (Thorda fia), Torda vm. alisp. (1449) l. Csáni 
Mihálcfalvi (v. Mihálcfalvai; FH; Iczkovits 59)

- Bakó, Fehér vm. szolgabírája (1357). Balázs testvére (1366: DRH. C. XIII. 247). Királyi (1357, 1359: CDTrans III. 903, 1100, 1111. sz.) és alvajdai ember (1367: DRH. C. XIII. 363, 411). Középvincen (FH) birtokos (1391: ZsOkl I. 1992. sz.). Magister, 1393-ban néhai (1393: uo. I. 3122. sz.). 51

- Péter (Jak fia), Fehér vm. szolgabírája (1406). Testvérei: László, Lőrinc és István (1391: ZsOkl I. 1992. sz.). Mihálcfalván (1393: uo. I. 3066. sz.) és Középvincen birtokos (FH; 1391: uo. I. 1992. sz.). 51

Mihály magister, erd. alvajda, Fehér vm. isp. (1322-1332). 50

- (Albert fia), B-Szolnok vm. isp. (1329-1332), Torda vm. isp. (1338) 1. Zsuki Mihály

- (Benche fia), Hunyad vm. szolgabírája (1395) 1. Bencefi Mihály

- (Dénes fia) comes/magister, Kolozs vm. szolgabírája (1312-1314) 1. Szentpéteri Mihály.

- (Kaza fia), Doboka vm. szolgabírája (1305) 1. Keresztesi Mihály

[---] Mihály, Küküllő vm. szolgabírája (1439). 82

Mike [?]/Miske (csesztvei; FH; Iczkovits 53)

- Tamás, Fehér vm. alisp. (1510). Csesztvei; Szentbenedeken (FH) birtokos (1516: KmJkv II. 3599. sz.). Csongván (FH) jobbágytelkeket vásárol; Imre, György, András, Krisztina, Orsolya, Borbála apja (1521: uo. II. 3821, 3833. sz.). Gabud és Gezse (FH) birtokbeli részeit csúcsi Tomori Istvánnak adja, amiért ez kiváltotta Mócs (KL) és Ispánlaka birtokrészeit, illetve csesztvei jószágát (FH, 1521: uo. II. 3833. sz.). 53
Myke comes, B-Szolnok vm. szolgabírája (1329). Talán azonos azzal a Myke-vel, aki 1308-1310 között bálványosi várnagy (1308: CDTrans II. 80. sz.; 1310: Kádár-Tagányi II. 109; 1334: CDTrans II. 829. sz.) és aki 1308-ban Szilágytőn (BSz) birtokot vásárol (1308, 1319: uo. II. 80, 321. sz.). 25

Mikeházi (BSz; Kádár-Tagányi V. 164166)

- Antal magister, B-Szolnok vm. szolgabírája (1399). Eml.: 1398: TelOkl I. 268. Ügyvéd (1430 [?]: KmJkv I. 36. sz.). Felesége: Kidei Inok leánya: Borbála; gyermekei: Mátyás és Erzsébet (DO, 1440: uo. I. 192. sz.). Királynéi kiküldött (1440: DL 27874). 26

- Bálint, B-Szolnok vm. szolgabírája (1487). Vajdai kiküldött (1487: DL 27952-27953). 29

- Fülöp, B-Szolnok vm. szolgabírája (1519). Vajdai kiküldött (1514: KmJkv II. 3581. sz.). Egregius, eskütárs (1517: uo. II. 3637. sz.; vö. DL 27997). 29

- Imre, B-Szolnok vm. szolgabírája (1509). A bethleni Bethlenek ügyvédje (1500: DL 27998). Vajdai kiküldött (1502, 1506: DL 27789, 27240; eml. 1503: DL 28002). 29

Mikei (Mykey; de Myke; DO)

- Péter, Doboka vm. szolgabírája (1431). Doboka vm. hatóságának megbízásából 1430-ban vizsgálatot tart (DL 74045). 38

Mikod, Doboka vm. isp. (1265) 1. Dobokai

Miklós comes (Gyerő fia), Doboka vm. isp. (1341) 1. Méhesi [?] Miklós comes

- comes (Albert fia) Kolozs vm. isp. (1339) 1. Zsuki Miklós

- (Kozma fia), B-Szolnok vm. szolgabírája (1392) 1. Szilágytői Miklós 
- comes (Péter fia), B-Szolnok vm. isp. (1325), Torda vm. isp. (1310-1312, 1326) 1. Gerendi Miklós

- (Simon bán fia), Küküllő vm. szolgabírája (1344) l. Szalók nb. Miklós (Simon bán fia)

- (Tamás fia), Kolozs vm. szolgabírája (1358-1359) 1. Járai Miklós

- Kolozs vm. isp. (1337) 1. Mérai Miklós, Kolozs vm. isp. (1334) és Zsuki Miklós (Albert fia), Kolozs vm. isp. (1339)

- magister (István fia), Doboka vm. isp. (1384). 1384 k. királynéi parancsra oltalmazza a Wass család birtokait (WassLt 186-187. sz.). Vélhetőleg Losonci László erd. vajda (1376-1385) és Losonci Miklós székely ispán (1382-1385) familiárisa (uo. 189. sz.). 34

- magister, Kolozs vm. isp. (1347) l. Vas Miklós

- deák, Kolozs vm. jegyzője (1524-1530). 79-80

- Kolozs vm. isp. (1315). Wertner M. tévesen azonosítja Pok nb. Meggyesi Miklós erd. vajdával (1315-1316) (TTár 8/1907. 15). 66

mikói cs: Kegye

Mikola (szamosfalvi, KL; Csánki V. 552

556; Engel: Gen., Mikola rokonsága, 7. tábla: Mikola, dezméri, szamosfalvi)

- László, Kolozs vm. isp. (1530-1533). Mikola Ferenc fia (1499, 1502: KmJkv II. 3085, 3260. sz.). Egregius (1521: uo. II. 3812. sz.). Erd. alvajda és székely alisp. (1537: иo. II. 4592. sz.), a kir. erdélyi helytartójának helyettese 1543-1545 között (1543, иo. II. 4797. sz.; vicelocumtenens regius: 1543-1544, Jósika cs hitb. lt 23-24. sz.; Kemény J. gyüjt. 1544. IV. 28.; Kemény cs malomfalvi lt, 100. sz., 1545. III. 21.), királynéi alhelytartó (1545: KmJkv II. 4850. sz.; helyettes királynéi helytar- tó: 1549: uo. II. 4941. sz.; 1549. XI. 6.: vicelocumtenens reginalis, Kemény J. gyüjt.), erd. főbíró helyettese (1545: KmJkv II. 4850. sz.). Korpádon (1520: uo. II. 3774. sz.), Szamosfalván, Oláhés Magyardezméren (1521, 1523, 1524: uo. II. 3803, 3930, 4014. sz.), [Puszta]szentmiklóson (1521: uo. II. 3812. sz.), Zsobokon, [Kalota]szentkirályon (1522: uo. II. 3845. sz., KL) birtokos. Zálogba vesz jószágrészeket Csapó, Sályi, Kocsárd (KK) birtokokban (1534: uo. II. 4459. sz.). A kolozsvári domonkos kolostor javára testvérével együtt adományt tesz (1521: uo. II. 3803. sz.). Síremléke a szamosfalvi róm. kat. templomban (Balogh J.: Kolozsvári kófaragó múhelyek. XVI. század. Bp. 1985. 329-330). 79

mindszenti cs: Esztári

Miske cs (bagói) 1. Bagói Miske

\section{Miskei}

- Ambrus, Doboka vm. alisp. (1471). 42 miskei cs: Török

Miskolc nemzetség: Panyit

Mócsi (KL; Csánki V. 557-559)

- István (Miske fia), Kolozs vm. szolgabírája (1373). Alvajdai ember (1369: DRH. C. XIII. 638; 1373: uo. XV. 384). 69

- Miklós (István fia), Kolozs vm. szolgabírája (1396). 70

- (de Machy) Miklós (Sandrinus fia), Kolozs vm. szolgabírája (1419-1424, 1429-1435), Kolozs vm. alisp. (1425). Felesége: némai Kakas Jakab leánya: Katalin (BSz, KmJkv I. 2105. sz.). Ügyvéd (1441, 1442, 1444: иo. I. 349, 427, 429,536 . sz.); vajdai és alvajdai kiküldött (1417, 1424: WassLt 339, 371. sz.; ZsOkl VI. 299. sz.; 1427: TelOkl I. 494). Egy 1422. IX. 30-i oklevélben (TelOkl I. 462) tévesen szerepel Doboka vm. neve, ez valójában Kolozs vm. kiad- 
ványa és Mócsi Miklós ennek a vm.nek a szolgabírája. 72-74

- Miske, Kolozs vm. szolgabírája (1425, 1426-1427). Barnabás fia (1427: DL 62800). Felesége: Csesztvei Erzsébet (FH, 1419: ZsOkl VII. 640. sz.). Alvajdai kiküldött (1426: DL 27008). 1430-ban az ősi Jankafiak tiltakoztak az ellen, hogy Zsigmond kir. Bagó, Szentkirály és Borsjakabfalva (FH), valamint Mócs, Csehtelke, Báld és Gyéres birtokokban (KL) levő jószágrészeiket Mócsi Miskének és rokonainak adományozta (1430: WassLt 406. sz.; vö. DL 27012). 73

- Simon (Mucz-i [?!]), Kolozs vm. alisp. (1466). Miske fia (1458: KmJkv I. 1281. sz.), Benedek apja (1473: DL 27050). Eml.: 1461 (KmJkv I. 1571. sz.). 76

Mocsk (gáji, TC, Engel: Gen., Mocsk; Pór A.: Macska Domokos, királyi kardhordó, erd. alvajda, 1357. In: Turul 27/1909. 130-132; Engel: Alvajda 181)

- Domokos, erd. alvajda (1356-1359; 1356: CDTrans III. 838. sz.; 1359: uo. III. 1090. sz.), Fehér vm. isp. (eml.: 1357). Királynéi udvari ifjú (1346-1349), Lackfi András familiárisaként Nyaláb (UG, 1349-1353), Aranyos (KSz, 1349-1350) és Huszt (MM) várnagya (1353), udvari lovag (1353-1366), baranyai alisp. (1354), lásd Engel: Arch. II. 168-169. Harcolt a tatárok és a ruténok ellen, illetve Itáliában (1349, 1357: CDTrans III. 533, 906. sz.). 51

Móré (csehi; DO; Cseh = Páncélcseh; Kádár-Tagányi V. 386)

- Miklós, Doboka vm. szolgabírája (1524, 1525, 1528). Páncélcsehen (DO) birtokos család tagja (KmJkv I. 983). Királyi ember (1518: DL 27413); 1526-ban ügyvéd (KmJkv. II. 4151. sz.). 46
Móré (More, zsombori, de Zombor; DO; Zsombor $=$ Szászzsombor; Kádár-Tagányi VII. 150)

- Gergely, Kolozs vm. alisp. (1478). 76

Mórici (szilkeréki; BSz)

- Péter, B-Szolnok vm. szolgabírája (1482). 28

Mórici (DO; Kádár-Tagányi V. 197)

- János (Márton fia), Doboka vm. szolgabírája (1315), Doboka vm. isp. (1321-1334). Azonosítására lásd WassLt 19. sz. (1326). István, Jakab és Thelman apja (1342: CDTrans III. 100. sz.). Jószágrésze volt Ôs birtokban (DO, 1333, 1342: uo. II. 783. sz.; III. 100. sz.). Fia Hesdát (DO) örökjogú birtokosa (1352: uo. III. 637. sz.). Comes (1332: uo. II. 753. sz.). Vajdai kiküldött (1315: uo. II. 256. sz.), fogott bíró (1321: uo. II. 410. sz.). Szécsényi Tamás erd. vajda serviense (1329: uo. II. 658. sz.); famulusa: 1341: uo. III. 78. sz. 32

Nadányi (BÉ; Borsa nb.; Karácsonyi: Nemzetségek 225, 231-233; Györffy I. 511; Csánki I. 653, 661; Engel: Gen., Borsa nem 2. Nadányi; Nadány $=$ Körösladány)

- László, Fehér vm. isp. (1406), erd. alvajda (1404-1406). Miklós fia (ZsOkl X. 1567. sz.); Márk apja (1405: uo. II/1. 3864. sz.). Békés vm.-ben birtokos (1411, 1412: uo. III. 1164, 1712. sz. ). Bihar vm.-i birtokot foglal el (1414: uo. IV. 1694. sz.; idézi Engel: Gen.). 51

Nádasdi (KL; Csánki V. 804; Nádasd = Magyarnádas)

- János, Torda vm. isp. (1446). 87

Nádasi (csehi; bádoki; DO; Cseh = Páncélcseh)

- György, Doboka vm. szolgabírája (1540-1548). A vm. okleveleiben 1540-1544 között csehi, 1546-1548 között bádoki. Doboka vm.-ben bir- 
tokos, Menyhárt Gergely leányának: Annának a fia (KmJkv II. 4788. sz.). 1554-ben eskütárs Doboka és Kolozs vm.-i birtokokért folyó perben, ekkor bádoki Nádasi Györgyként említik (DO; uo. II. 5278. sz.). 47

Nádasi (KL; Csánki V. 385-386, 559-560; Nádas = Magyarnádas)

- Domokos (Lőrinc fia), Kolozs vm. szolgabírája (1396). Királyi kiküldött (1418: ZsOkl VI. 1848. sz.). 70

- Ferenc, Kolozs vm. szolgabírája (1516-1517, 1533). Rődi néhai Cseh Miklós fia [?] (1525: KmJkv II. 4079. sz.). Felesége: sólyomkői Menyhárt Gergely leánya: Katalin (1526: uo. II. 4159. sz.). Gyermekei: György, Péter, Bálint, János, Anna, Fruzsina és Mihály (1522, 1525: uo. II. 3880, 4079. sz.). Vajdai kiküldött (1501: uo. II. 3173. sz.), fogott bíró (1508: uo. II. 3458. sz.). Vataháza prédiumban (KL) jószágrészt vásárol; egregius (1522: uo. II. 3880. sz.). 1539-ben néhai (uo. II. 4722. sz.). 79-80

- László magister (László fia), Kolozs vm. isp. (1366). Felesége: Bongárdi Pető leánya (1351: CDTrans III. 615. SZ.; 1367: DRH. C. XIII. 313; 1372: uo. XIV. 230). Nádasi (1367: uo. XIII. 313, 429). Járai Péter erd. alvajda szentimrei officiálisa, aki az alvajdának járó adót a Kolozs és Doboka vm.-i szolgabírákkal együtt kell hogy behajtsa (1366: TelOkl I. 168; 1363 v. 1368: uo. I. 92); részt vesz I. Lajos kir. 1371. évi hadjáratában, érdekében a kir. perhalasztást rendel el (1371: uo. I. 171). Alvajdai ember $(1365,1368:$ DRH. C. XII. 403; uo. XIII. 467), vajdai kiküldött (1372: uo. XIV. 180). 68

Nagy Gergely (andrásházi) Gergely, Kolozs vm. szolgabírája (1439-1446) 1. Andrásházi „Nagy” Gergely

Nagy Gergely 1. Budai (sárdi) Gergely
Nagy (botházi, KL; Csánki V. 560)

- Simon. Csánki V. 560. szerint Kolozs vm. szolgabírája (1473), de a hivatkozott oklevelekben nem lelhetô fel ez az adat (1473: KmJkv I. 2096. sz.; DL 26906: Simon ekkor már néhai; DL 27050)

Nagy (Magnus; kápolnai; BSz)

- Fülöp, Doboka vm. alisp. (1471). 42

- Tamás, Doboka vm. alisp. (1471). 42

Nagy (Magnus; sáromberki, TD; Csánki V. 804)

- Imre, Torda vm. alisp. (1448). Felesége: Vincen lakó Kosa/Kasa László leánya, aki Peterden (TD) birtokos. Gyermekeik: György, Ilona, Erzsébet (1449: KmJkv I. 780. sz.). 87

Nagy (Nagh; szentmiklósi; KL; Csánki V. 561; Szentmiklós = Pusztaszentmiklós)

- Ambrus, Kolozs vm. szolgabírája (1524). 79

Nagy (Magnus; szilágyi)

- Jakab, Doboka vm. alisp. (1444). 39

Nagy (Magnus; szucsáki; KL; Csánki V. 561-562)

- Benedek, Kolozs vm. alisp. (14821488). Szomordokon és Nádason (KL) birtokos (1489: KmJkv II. 2708-2709. sz.). Fogott bíró (1474, 1478, 1482, 1486: uo. I. 2156, 2253, 2353. sz.; II. 2629. sz.), királyi kiküldött (1479: TTár 1907. 98. = DF 244549). Ügyvéd (1489: KmJkv II. 2704. sz.). 77

- Kelemen, Kolozs vm. szolgabírája (1462-1465, 1468). Szucsáki Nagy Mihály fia, Szomordokon (KL) birtokos (1460: KmJkv I. 1448. sz.). Ügyvéd (1467: uo. I. 1720. sz.). 76

Nagy (Magnus; túrcsáni, de ThwrChan; TD; Csánki V. 804; Túrcsán = Pusztacsán) 
- János, Torda vm. szolgabírája (1485-1487). Fia: Máté (1508: KmJkv II. 3447. sz.). [Túr]csán (TD) határában jószágrészt vásárol (1501: uo. II. 3200. sz.), Remetén, Kisremetén és Szurdokon jószágrészt vesz zálogba (TD; 1507, 1508: иo. II. 3421, 3447, 3479. sz.). 1509-ben túrcsáni örökjogú részét eladja, ingóságait unokáinak ajándékozza el (1519: uo. II. 3738). 89

Nagy (Nagh; újbudai, KL; Csánki V. 450)

- Domokos, Kolozs vm. szolgabírája (1509). Imre fia (1501: Csánki V. 450). 78

Nagy (zalai, DO; Zala/Zalaháza eltűnt település Esküllő közelében)

- György Pál (Paulus Georgius Magny [!] de Zala), Kolozs vm. isp. (1468). 76

Nagy (Magnus; zsombori, DO; Zsombor = Szászzsombor)

- Albert, Doboka vm. alisp. (1479-1481, 1487). 1476-ban királyi kiküldött (DL 27530). 43

Nagy (Magnus) családbeliek

- Ambrus, B-Szolnok vm. isp. (1468). Talán devecseri Nagy (Magnus) Benedek fiával: Ambrussal azonos (1453: KmJkv I. 1091. sz.). 28

- Bálint, Doboka vm. isp. (1475). Talán azonos Szakácsi Nagy Bálinttal (1450: TelOkl II. 43; 1461: KmJkv I. 1639. sz.; 1472: иo. I. 2059. sz.), aki a bélteki Drágfiak és kusalyi Jakcsok ügyvédje (1459: иo. I. 1376. sz.; 1461: иo. II. 1560. sz.). 42

- Barnabás, B-Szolnok vm. alisp. (1482). 28

- Bertalan, Doboka vm. alisp. (1470). 42

- János, B-Szolnok vm. alisp. (1484). 28

- Máté, B-Szolnok vm. alisp. (1495). 29

- Pál, B-Szolnok vm. isp. (1470). 28

- Pál, Doboka vm. alisp. (1470, 1475, 1476). Talán azonos az 1460-ban és 1461-ben említett Csomafáji Nagy
Pállal (KmJkv I. 1496, 1608. sz.) vagy azzal a Nagy Pállal, aki 1470-ben B-Szolnok vm. isp. (Kornis cs lt, DF 257678). 42-43

- Pál, Hunyad vm. isp., Hunyad vár várnagya (1481-1483). 57

- Tamás, Kolozs vm. alisp. (1493 k.). 77

nagyszentmihálytelki cs: Olcsárdi

Nagyvátyi (BAR?) György, Fehér vm. szolgabírája (1536). 54

Naláci (HD; Csánki V. 213)

- István, Hunyad vm. szolgabírája (1520, 1524-1544). Királyi kiküldött (1518: DL 29964). 62, 64

Nána-Beszter nemzetség: Haranglábi

Némai (némai, KmJkv II. 3958. sz.; BSz; Kádár-Tagányi V. 226)

- Gergely, B-Szolnok vm. szolgabírája (1435). Ügyvéd $(1439,1449:$ KmJkv I. 126, 650. sz.). 27

- István (Pető fia) 1. István (Pető fia)

- Mihály (Pető fia), B-Szolnok vm. szolgabírája (1392). 26

- Tamás, B-Szolnok vm. szolgabírája (1509). Felesége: Anna (1523: KmJkv II. 3905. sz.). Gyermekei: Margit és Erzsébet (1523: uo. II. 3950. sz.). Némán és Bekében (BSz) birtokos (1523-1524: uo. II. 3950, 3958, 4031. sz.). Vajdai (1501: Veress: Acta et epistolae IV. 56) és királyi ember (1514: KmJkv II. 3585. sz.). 29

németi cs: Fejér

nemzetség: Agmánd, Ákos, Balog, Balogsemjén, Becsegergely, Borsa, Brassói-rokonság, Csák, Geregye, Gútkeled, Kacsics, Kán, Demjén, Hermán, Hontpázmány, Kaplyon, Káta, Kökényesradnót, Miskolc, Nána-Beszter, Szalók, Szentemagócs, Tomaj, Tyukod, Zsombor

Németi (BSz; Kádár-Tagányi VI. 259) 
- Albert magister, [Belső-]Szolnok vármegye nótáriusa (1479). Deák, ügyvéd (1469: KmJkv I. 1874. sz.). 43

Nényei (Nenyey) István, Hunyad vm. isp., Hunyad vár várnagya (1544). 64

Novaji (KL; Csánki V. 563)

- Fülöp, Kolozs vm. szolgabírája (1441-1446). Ügyvéd (1440, 1454: KmJkv I. 272, 1137. sz.), fogott bíró (1450, 1454: иo. I. 922, 1173. sz.). 1461-ben néhai; öröksége Novaj (KL, uo. I. 1636. sz.). 74-75

nótárius 1. jegyző

novaji cs: Sztrigyi

Nucden, curialis comes, Kolozs vm. (1235). 66

Nyitrai Péter, Kolozs vm. isp. (1288). 66 Nyíresi (boncnyíresi, DO)

- István, Doboka vm. szolgabírája (1414-1415, 1426-1430). $\rightarrow$ Lukács és $\rightarrow$ Mihály, továbbá György, Tamás, Erzsébet, Márta és Magdolna apja (1439: KmJkv I. 126-127. sz.). Nyíresen birtokos (DO; 1415: BánfOkl I. 537), Ugrócon és Szúnyogszegen (BSz) csere útján szerzett birtokokat, csere révén Igrice felének is birtokosa (1405: ZsOkl V. 327. sz.). Jószágrészei voltak Nyíres, Mányik és Móric birtokokban (DO 1416, 1417: uo. V. 2520. sz., VI. 52. sz.; vö. 1439: KmJkv I. 127. sz.). Királyi ember (1426: WassLt 373. sz.). 36-38

- János (Domokos fia), Doboka vm. szolgabírája (1341). Valószínűleg azonos azzal a Domokos fia: Jánossal, aki 1318-ban testvérével együtt eladja Boncnyíres negyedrészét cegei id. Wass Miklósnak (DO; CDTrans II. 294. sz.; WassLt 30. sz.) és aki vajdai kiküldött (1340: uo. 62. sz.), vajdai közgyülésén Doboka vm.-ből választott esküdt ülnök (1344: CDTrans III. 227. sz.). 33
- Lukács, Doboka vm. szolgabírája (1448). $\rightarrow$ István fia (1439: KmJkv I. 126-127. sz.). Fia: Pál apja, felesége: Erzsébet (1457: uo. I. 1283. sz.). Boncnyíresen birtokos (1439: uo. I. 121. sz.). Jószágrésze volt Alsó- és Felsőtőkön (1442: uo. I. 439, 442. sz.), Mányikon és Móricon (1439: uo. I. 127. sz.). Felsőtőki jószágrészét - testvéreivel együtt - 1442-ben zálogosította Agmándi Péter váci püspöknek (uo. I. 439. sz.). Ügyvéd (1442: uo. I. 443. sz.). 40

- Mihály, Doboka vm. szolgabírája (1453-1466). $\rightarrow$ István fia (1439: KmJkv I. 126-127. sz.), Tamás deák apja (1484: DL 27546). Boncnyíresen birtokos (1465: WassLt 461. sz.). Jószágrészei voltak még Mányikon, Móricon (1439, 1475: KmJkv I. 127, 2198. sz.), Alsó- és Felsőtőkön (1442, 1468, 1472: uo. I. 442, 1832, 2065. sz.; 1484: DL 27546). Felsőtőki jószágrészét - testvéreivel együtt - 1442-ben elzálogosította Agmándi Péter váci püspöknek (1442: KmJkv I. 439. sz.). Több alkalommal ügyvéd (1440, 1442, 1459: uo. I. 199, 443, 1387, 1390. sz.), 1468-ban tanúként idézik egy Doboka vm.-i perben (tőki Nyíresi Mihály, DL 27498). 41-42

óbudai cs: Budai

Oláh (Olah) András, Doboka vm. isp. (1475). 42

olaszi cs: Cine

Olcsárdi (Olchardy, nagyszentmihálytelki, KL; Csánki V. 563, 622)

- János, Kolozs vm. szolgabírája (1514, 1518). Várcai (KL, 1508: KmJkv II. 3458. sz.). Fogott bíró (1518, 1529, 1531: uo. II. 3698, 4244, 4337. sz.). Részbirtokot vásárol Szentmihálytelkén (KL; uo. II. 4849. sz.). 79

Olnoki (v. Ónoki, DO; Kádár-Tagányi V. 285) 
- Barnabás, Doboka vm. szolgabírája (1384). János fia, Ónok (DO) birtokosa (1371: DRH. C. XV. 17), $\rightarrow$ István apja (1426: WassLt 373. sz.). Vajdai kiküldött (1370: TelOkl I. 164; 1376: DRH. C. XV. 101). 34

- István, Doboka vm. szolgabírája (1423-1429). $\rightarrow$ Barnabás fia (1426: WassLt 373. sz.). 37-38

- Pál, Doboka vm. szolgabírája (1397-1401, 1414). Alvajdai ember (1431: DL 27463). 35-36

Oppor (László fia), Küküllő vm. szolgabírája (1331) 1. Ebesfalvi Oppor

osztorói cs: Hátszegi

Ózdi (FH; Iczkovits 60)

- Illés, Fehér vm. szolgabírája (1494). 53

Ördög (sólyomkői, DO; Engel: Gen., Zsombor nem, 1. tábla: Ördög, sólyomkői, esküllői)

- Miklós, Doboka vm. szolgabírája (1416-1419). Az Ördög család a Zsombor nem kiágazása, fontosabb birtokai: Esküllő, Bábóc, Kovácsi, Sólyomkő, [Magyar-, később Borsa]újfalu, Fodorháza, Nagyesküllő, [Ördög]keresztúr, Köblös, Szentkatolna, Szótelke (DO, 1395: ArhIstRom 2/2004. 22-23. = DL 27441; sólyomkői Botos János öröksége, 1441: DL 27474). Ördög Miklós szótelkei birtoklásáról maradt fenn oklevél (1408: ZsOkl II/2. 6026. sz.). Ügyvéd (1423: WassLt 367-368. sz.). 1431-ben néhai (KmJkv I. 78. sz.). 37

özdögei cs: Besenyő

Pál, Doboka vm. isp. (1273). Egyidejűleg szörényi bán (1272-1274) és valkói isp. (1273-1275). További tisztségeire és azonosítására lásd Zsoldos: $A r$ chontológia 342. 32

- deák, Torda vm. isp. (1446). 87
- magister (Kochka Mihály fia), Torda vm. szolgabírája (1321). 85

- B-Szolnok vm. isp. (1368) 1. Besenyő Pál

Palásti ([mezőkeszi?, HT?])

- Péter, B-Szolnok vm. isp. (1509). Vö. Csánki V. 235 (Szentimrei cs); 1504, 1509: DL 30507, 30339. 29

Pálosi (FH, KK) Gergely, Küküllő vm. isp. (1536). 83

palotai cs: Cibak

Panyit, Doboka vm. isp. (1268). Szörényi bán (1270: RegArp II/1. 1963. sz.), zalai isp. (1270, 1270-1272, 1272), gecskei isp. (1272-1273), lásd Zsoldos: Archontológia 50, 148, 232, 274. Miskolc nb. (1270: ÁÚO XII. 7. = RegArp II/1. 1994. sz.; Karácsonyi: Nemzetségek 823-824; Engel: Gen., Miskolc nem, 9. tábla, töredékek). Pál fia (1263: CDTrans I. 242. sz.). István ifjabb kir. híve, akinek oldalán a feketehalmi és isaszegi csatában is harcolt IV. Béla kir. ellen; a tatárokhoz küldött követ (Zsoldos: IV. Béla és István 66, 95; Szűcs J.: Az utolsó Árpádok. Bp. 1993. [História könyvtár. Monográfiák 1]. 111, 117). Borsod vm.-ben birtokos. (Györffy I. 789; RegArp II/1. 1884. sz.). 31

papfalvi cs: Csoronk

Parvus 1 . Kis

Patai (KL; Csánki V. 566-567; vö. patai Dezső)

- János (Imre fia), Kolozs vm. szolgabírája (1373-1388, 1390). Csánki V. 567. szerint - forrást nem idéz - 1384-ből is lenne adat a szolgabíróságára. 69

- János, Kolozs vm. szolgabírája (1451). Patai Dezső (1431[?], 1439, 1440, 1449: KmJkv I. 72, 133, 243, 684. sz.) vagy Patai Imre fia (1439: иo. II. 134. sz.). Patán (KL) birtokos (1439: uo. II. 133-134. sz.). Patai Dezső fia: János 
rődi, bósi és patai (KL) jószágrészt vesz zálogba (1440: иo. II. 243. sz.). Patai Imre fia: János Rődön birtokos (1442: иo. II. 394. sz.). Ügyvéd (1452: uo. II. 1062. sz.). 1458-ban Patai Dezső fia: János néhai (uo. II. 1325. sz.). 75

\section{patai cs: Dezsó}

Patócsi (iregdi, AR; Csánki I. 786)

- Péter, Hunyad vm. isp. (1516), Hunyad vár várnagya (1513-1516). Sarudi. Brandenburgi György familiárisa (1514: MonRustReb 306). 61

Pázmány (Pazman), Kolozs vm. isp. (1201). Poznan 1193-ban tolnai isp. (RegArp I/1. 155. sz.). 65

Páznádi (TS; Csánki V. 216; Páznád = elnéptelenedett település Temeskenéz és Kisbecskerek mellett)

- Ferenc deák Hunyad vm. isp./alisp. (1446-1452), hunyadi várnagy (1446-1456). [Páznádi] Ferenc hunyadi várnagyot Hunyadi János nagyobbik fia, Hunyadi László kir. lovászmester (1456-1457) a „mi várnagyunk"-nak nevezi (1456: Sz[abó] K.: Jelentés a vajda-hunyadi görög catholikus egyház levéltáráról. In: Századok 21/1887. Pótfüzet p. 49). Id. Rozgonyi István familiárisa 1439-ben (Bártfai Szabó L.: A sárvárfelsővidéki gróf Széchényi család története. I. Bp. 1911. 552, idézi Engel: Arch. II. 187), később a Hunyadi család familiárisa. 56-57

Perényi (AJ; Csánki I. 230; Engel: Gen., Perényi, 1. tábla: nyalábi ág)

- (de Puren) Péter, Küküllő vm. isp. (1344). Említve: DL 75361 (1345). Orbán-fi János fia (Engel: i.m.). 81

Pestesi Benche fia: Mihály, Hunyad vm. szolgabírája (1395) 1. Bencefi Mihály pestesi cs-ok: Bencefi, Bíró, Csanádfi petendi cs: Burján

Péter, Kolozs vm. alisp. (1414). 71
Péterházi (BSz; Agmánd nemzetség, Péterházi cs)

- Péter, Belsőszolnok vm. szolgabírája (1488). Királyi ember (1488: DL 30052, Kádár-Tagányi VII. 205). 29

Péterfalvi András, Küküllő vm. alisp. (1478), küküllővári várnagy (1478) 1. Porkoláb András

péterfalvi cs: Burján, Porkoláb

Petlendi (TD; Csánki V. 809. Petlend = elnéptelenedett település Túr határában)

- Pál, Torda vm. szolgabírája (1463). Fogott bíró (1449: KmJkv I. 710. sz.), ügyvéd (1459: uo. I. 1381. sz.). 88

\section{petlendi cs: Egresi, Solymos, Veres}

\section{Phicor 1. Ficsor}

piskenci cs: Aranyi

Pókai (TD; Csánki V. 809)

- András, Torda vm. szolgabírája (1447), Torda vm. alisp. (1448). 87

- „Porkoláb” Bereck, várnagy, Torda vm. isp. (1462-1463). Talán azonos $\rightarrow$ Bereck várnaggyal, aki Kolozs vm. isp. (1462). 88

Polyeni (HD; Csánki V. 126, 128)

- János, Hunyad vm. alisp., Hunyad vár várnagya (1477). 57

Porkoláb (ádámosi, KK; Csánki V. 952 953)

- Imre, Küküllő vm. szolgabírája (1507). János fia; Ádámoson nemesháza, Kocsárdon, Sályin és Csapón (KK) jószágrésze volt (1503: KmJkv II. 3280. sz.). 1503-ban jószágrészt adományozott (valószínűleg famulusának, 1503: иo. II. 3281. sz.). Szentgyörgyi Péter erd. vajda és székely isp. fövesztésre ítélte jogtalan eljárás miatt (1507: uo. II. 3417. sz.). 1509-ben még említik (uo. II. 3517. sz.). 82

Porkoláb (bácsi, KL)

- János, Kolozs vm. alisp. (1465-1466). 76 
Porkoláb (botházi, KL; Csánki V. 569)

- Mihály, Kolozs vm. szolgabírája (1476, 1482, 1484, 1491). András, Pál és Péter apja (1480, 1486, 1492: KmJkv I. 2291, II. 2570, 2777 sz.). Fogott bíró (1482: uo. I. 2337, 2407. sz.). 76-77

Porkoláb (göci) Mátyás, Doboka vm. szolgabírája (1505, 1513), Doboka vm. alisp. (1513) 1. Göci Mátyás

Porkoláb (péterfalvi, KK; Csánki V. 953)

- András, Küküllő vm. alisp., [küküllővári] várnagy (1478), Küküllő vm. isp. (1479). Meggyesfalvi Zsófia férje, János, Simon (1483: KmJkv I. 2426. Sz.), Lőrinc (1503: uo. II. 3280. sz.) és Zsigmond apja (1505: uo. II. 3349. sz.). Péterfalvi Porkoláb András, ügyvéd (1482: uo. I. 2357. sz.). 1492-ben Cicsó és Küküllővár István (Ştefan) moldvai vajda részére történő iktatásánál királyi ember (Veress: Acta et epistolae IV. Bp. 1914. 44). 82

Porkoláb (szentgyörgyi, BSz; Szentgyörgy = Vízszentgyörgy, puszta Széplak közelében)

- Sandrinus, B-Szolnok vm. szolgabírája (1476). Ügyvéd (1482: KmJkv I. 2422. sz.). 28

Porkoláb (szucsáki, KL; Csánki V. 571)

- Demeter, Kolozs vm. szolgabírája (1488), Bánffy Ferenc sebesvári (KL) várnagya (1493: DL 32515). Özvegye: Orsolya (1498: KmJkv 3071. sz.). Ügyvéd (1490: uo. II. 2710. sz.). Fogott bíró (1497: uo. II. 3006. sz.). 77

- György, Küküllő vm. isp. (1538). 83

Porkoláb (tompaházi, FH)

- Józsa, Fehér vm. szolgabírája (1522). 53

\section{Porkoláb}

- Demjén, Torda vm. alisp. (1469). Rédei János erd. alvajda familiárisa (1469: KmJkv I. 1851. sz.). 88
Porkoláb Bereck, Torda vm. isp. (1462-1463) 1. Pókai „Porkoláb” Bereck

Porkoláb Mátyás, Doboka vm. alisp. (1513) 1. Göci Mátyás

Pous, tárnokmester, Fehér vm. isp. (1227) 1. Csák nb. Pós

Radnóti Bord (d) László, Küküllő vm. szolgabírája (1407) 1. Bordi

Rafael, Küküllő vm. isp. (1214), erdélyi vajda (1217). Lásd Zsoldos: Archontológia 37, 167, 348. 81

Rákosi ([abosfalvi]; FH; Csánki V. 953) Mihály, Küküllő vm. szolgabírája (1536-1538). 83

\section{Rákosi (HD)}

- Gáspár, Fehér vm. alisp. (1494). Vajdai ember (1506: DL 26491). 53

Rápolti (HD; Csánki V. 221-222; KmJkv I. p. 56-58)

- György, Hunyad vm. isp. (1467). Mátyás fia: Péter fia; Gothárd kolozsmonostori gubernátor és gyulafehérvári prépost testvére (KmJkv I. 1506. sz.). Felesége: Borbála, leányai: Ilona (Macskási „Tárnok” Péter szörényi bán felesége), Katalin (albisi Zólyomi Dávidné), Margit (Ráskai Mihályné), Márta (Ravazdi Péterné); Hari (FH) birtokosa; 1500-ban néhai (DL 30950). 76

- Mátyás, Hunyad vm. isp. (1439-1446), dévai várnagy (1446-1458). Ügyvéd (1440, 1452: KmJkv 184, 1024. sz.). 56

Rátót nemzetség: Lesták, Kakas cs

Ravasz (szucsáki, KL; Csánki V. 573574)

- Lukács, B-Szolnok vm. szolgabírája (1470). Szucsáki Ravasz Domokos fia ([1430?], 1495: KmJkv I. 43. sz.; II. 2965. sz.). Felesége: Péterházi/Gyékényesi Balázs leánya: Ágota (1458: uo. I. 1283. sz.; 1487: uo. II. 2647. sz.). Péter apja (1487: DL 27949). A losonci 
Bánffyak ügyvédje (1461, 1472 [?]: uo. I. 1585, 2061. sz.). Fogott bíró (1485: uo. II. 2514. sz.). 28

Récsei (kidei, DO; Csánki V. 584)

- Gergely, Doboka vm. szolgabírája (1450-1452). Récsei Miklós (1441: DL 27474) vagy Récsei Yhthor (d) Mátyás fia (1459: KmJkv I. 1401. sz.), cegei Wass János leánya: Dorottya férje (1473: DL 27519), Jakab, Lőrinc, György/Gergely, gyulai Porkoláb Istvánné Katalin és Ilona apja (1469, 1475, 1478, 1504: KmJkv I. 1914, 2184, 2257. sz.; II. 3303. sz.). Récsén (KA, 1468: DL 29828) birtokos, Szentmiklóson (KL; KmJkv I. 1894. sz.) és Oláhkecelen (KA) zálogbirtokos (1471: uo. I. 2036. sz.). Ügyvéd (1440-1441, 1444, 1451, 1453, 1461, 1466, 1472: иo. I. $183,306,485,981,1090,1564,1714$, 2061. sz.). Alvajdai (1441: DL 27474) és királyi kiküldött (1451: DL 27883), 1469-ben familiárisát említik (TelOkl II. 100). 40

Rédei (HS; Csánki I. 83)

- János, erd. alvajda (1468-1472), Hunyad vm. isp. (1468-1469). Heves vm. alisp. (1461-1467, 1. Havassy P.: Heves megye középkori tisztségviselői. Eger 1986. 39-40). Pecsétje: TelOkl II. 111. 57

Remetei (TS?, KS?)

- Zakariás, Hunyad vm. alisp. (1508). 61

Rimai (GM; az almágyi nemesek egyik ága)

- (d) Miklós magister (Miklós fia), kolozsvári (!) ispán (1331), Kolozs vm. isp. (1332), kecskési várnagy (1322), létai várnagy (1331-1341). Lásd Engel: Arch. II. 205.66

Rohodi (de Rohod, SzR [?], 1511: DL 62392)
- János, Hunyad vm. isp. (1496). Fogott bíró a Corvin János özvegye, Frangepán Beatrix és Hunyad vm. nemessége közötti vitában (1507: DL 37813). Talán azonos azzal a Rohodi Jánossal, aki 1499-ben a görgényi (TD) várnagygyal együtt részesül Hunyad vm.-i királyi adományban (DL 29546), illetve aki 1500-ban Szentgyörgyi Péter erd. vajdától és székely ispántól kap parancsot egy marosszéki eljárás lefolytatására (SzOkl III. 145-148; a felsorolt adatok forrása: Neumann T.: Felső-Tisza-vidéki nemesek a késő középkori Nyitra megyében. In: Szabolcs-Szatmár-Beregi Szemle 42/2007. 4. sz. 440-441). 59

Roth (Rod, Rood; zsombori, DO)

- András, Doboka vm. szolgabírája (1487). Szászzsomboron kúriája volt (1499: KmJkv II. 3080. sz.). Vajdai ember (1482, 1495: DL 27543, 27564). 43

- János, Doboka vm. szolgabírája (1524-1525, 1536-1540). Ilona férje (1505: KmJkv II. 3378. sz.). Vajdai ember (1533: WassLt 656. sz.). +1540. III. 16. e. (uo. 664. sz.). 46-47

rődi cs: Cseh

Rufus 1. Veres

Sándor bán (Drug fia), Doboka vm. isp. (1274) 1. Karászi Sándor

Sándor (szamosfalvi, KL)

- András, Kolozs vm. szolgabírája (1533). Berenden zálogbirtokos (KL, 1536: KmJkv II. 4566. sz.). 80

Sándorházi (szucsáki, KL; Csánki V. 574-575)

- Ambrus, Kolozs vm. alisp. (1510). $\rightarrow$ György fia (1486: KmJkv II. 2573. sz.). Felesége: Orsolya, gyermekei: Benedek, Tamás, Mihály, sárdi Hacaki Gáspárné Márta, Borbála, Zsófia, Katalin (1524: uo. II. 4058. sz.). Gyalu (KL) erd. püspöki vár várnagya, egregius (1477: Kemény cs csombor- 
di lt, DF 280922; 1478: Suky cs lt, DF 255243; 1479: DL 27213; Kemény cs csombordi lt, DF 280924; 1482: uo., DF 280928; az adatok forrása: Horváth Richárd kéziratos váradattára). Szomordokon (KL) birtokos (1489: KmJkv II. 2708. sz.). Bócon (KL) jószágrészt vásárol (1518: uo. II. 3690. sz.). Szucsákon (KL) birtokos (1526 uo. II. 4148. sz.). 1482-ben Sándorházi Ambrus gyalui várnagyot említik (TTár 1907. 99-100). Fogott bíró (1508, 1510: KmJkv II. 3458, 3531. sz.), ügyvéd (1523: uo. II. 3954. sz.). 78

- György, Kolozs vm. alisp. (1491-1492, 1497). $\rightarrow$ Ambrus, László, János és Tamás apja (1486: KmJkv II. 2573. sz.). Felesége: Margit (1489: uo. II. 2708. sz.). Szomordokon (KL) birtokos (1489: uo. II. 2708. sz.). Ügyvéd (1490: uo. II. 2710. sz.), királyi kiküldött (1479: TTár 1907. 98. = DF 244549). $77-78$

Sárdi (KL; Csánki 575-577)

- András, Kolozs vm. alisp. (1423-1424). 72

- (Kis) Antal, Doboka vm. alisp. (1510). Minden bizonnyal azonos azzal a Sárdi Antal Kolozs vm.-i nemessel, aki fogott bíró a Gyerőfiek perében (1508: KmJkv II. 3458. sz.). 44

sárdi cs: Budai, Hátszegi

sáromberki cs: Nagy

Sárosi (szengyeli, TD; Csánki V. 811)

- Albert, Torda vm. szolgabírája (1484). 89

- Bernát, Torda vm. szolgabírája (1508). Szengyelen (TD) birtokos (1516: KmJkv II. 3598. sz.). 89

Sárosi (KK? KL?; Csánki V. 577)

- János, Kolozs vm. isp. (1441). 74

Sásvári (UG) Miklós, Torda vm. isp. (1494). Talán azonos azzal a Sásvári Miklóssal, aki Doboka vm.-i birtoko- kat próbál megszerezni (1492: KmJkv II. 2764. sz.) és aki Cikudon (TD) jószágrészt vásárol; egregius (1520: uo. II. 3792. sz.). 89

Saul magister, Hunyad vm. isp. (1365). 55

Sebestyén, Kolozs vm. isp. (1229). 66

- Doboka vm. jegyzője (1516). 45

semjéni cs: Kállói

Septéri (KL; Csánki V. 577, 811)

- Gyula, Torda vm. alisp. (1448, 1453), Fehér vm. isp. (1455). Ügyvéd (1450: KmJkv I. 855. sz.). 52, 87-88

Sértő (Serthew, kolozsvári; Tonk S.: A középkori közjegyzőség Erdélyben. In: Müvelődéstörténeti tanulmányok. Buk. 1980. 60, 273-274, 59. sz. jegyz.)

- Péter magister, Kolozs és Torda vm. isp. (1462). Mihály fia (1447, 1453: KmLt 171. sz. = DF 275238; DL 30316). Providus; eladja birtokát (1439: KmJkv I. 122. sz.); deák (1452: uo. I. 1023. sz.); magister (1450: uo. I. 845. sz.). Ügyvéd (1440, 1452, 1459: uo. I. 193, 1028, 1389. sz.). Császári közjegyző (1445: Nagybányán, Ub V. 155-156; 1447: KmLt 171. sz.; 1453: Sáromberkén, Petrus Michaelis Serthew de Cluswar, DL 30316). Tarkői Rykalf fia: György erd. alvajda aljegyzője 1451-1461 között (subnotarius; 1451: TelOkl II. 45; Ub V. 328-329; 1461: alvajdai subnotarius; DF 277554; KmJkv I. 1590. sz.), vajdai kiküldött (1451: TelOkl II. 45). Kolozsvári háztulajdonos 1453-ban (Szabó K.: A kolozsvári magyar polgárság összeírása 1453-ban. In: TTár 1882. 527, 730, Tonk: i. m.). Tordán lakik, Egyházasfalván birtokos (1459: KmJkv I. 1389. sz.; Csánki V. 702). 76, 88

Simon, Hunyad vm. isp. (1431). 56

- Kolozs vm. alisp. (1445). 74 
Solymos (petlendi, TD; Csánki V. 812; Petlend = elnéptelenedett település Túr határában)

- Miklós, Torda vm. szolgabírája (1436). Gyermekei: Pál és $\rightarrow$ Zsigmond ([1452?]: KmJkv I. 1061. sz.). Ügyvéd (1430, 1439: иo. I. 37, 137. sz.). 86

- Zsigmond, Torda vm. szolgabírája (1453). $\rightarrow$ Miklós fia ([1452?]: KmJkv I. 1061. sz.). Ügyvéd (1449, 1468: uo. I. 775, 1833. sz.). 1452-ben Berkes (TD) bitorlása miatt tiltakozik ([1452?]: uo. I. 1061. sz.). 88

sólyomkői cs: Ördög

Somai (KL; Csánki V. 578-579; Soma = elpusztult település Szucság közelében)

- Gergely, Kolozs vm. alisp. (1445), Kolozs vm. szolgabírája (1465-1466). Felesége: Újbudai Nagy (Magnus) János leánya: Márta (KL, 1449, 1471: KmJkv I. 652, 2042. sz.), gyermekei: Imre, Gergely/György, Nyíresi Mihályné Ilona, Némai Tamásné Anna, Orsolya (1470, 1492: uo. I. 1953. sz.; II. 2784. sz.). Jakab fia; Szucsákon (1446, 1449, 1469: uo. I. 576, 652, 1878. sz.) és Somán (KL) birtokos (1470, 1474: uo. I. 1953, 2156. sz.), Újbudán (KL) jószágrészt vásárol (1471: uo. I. 2042. sz.). Ügyvéd (1447, 1461: uo. I. 611, 1602. sz.), fogott bíró (1460, 1474: uo. I. 1448, 2134. sz.), királyi ember (1472: uo. I. 2062. sz.). 74

Sombory l. Zsombori

somkereki cs: Erdélyi

Suky l. Zsuki

Sulyok (szancsali, KK; Csánki V. 959960)

- Benedek, Torda vm. isp. (1508). György fia; Benedek, György és Borbála apja; ősi birtoka Szancsal (KK). Nővérétől, Györgyfalvi „Henke” Salatielné Katalintól ennek férje által vásárolt patai (KL) jószágrészt kap
(1519: KmJkv II. 3712. sz.). Szancsalon jobbágytelkeket vásárol (1513: DL 29945). Királyi és vajdai ember (1514, 1515, 1519, 1524: DL 30269, 26527, 29971, DL 26550). 89

- Demeter, Küküllő vm. szolgabírája (1513). Alvajdai, vajdai és királyi ember (1497, 1501, 1503, 1505, 1510, 1514, 1515: DL 29888, 29899, 29905, 29744, 26510, 29931, 29931, 30269, 26527). 82

- Menyhárt, Küküllő vm. szolgabírája (1532). 82

Sülyei (FH; Iczkovits 62; Csánki V. 958959)

- Gergely, Fehér vm. szolgabírája (1435). 52

- Illés, Torda vm. isp. (1436). Kormányzói ember (1448: DL 30445). 86

- István, Fehér vm. szolgabírája (1357-1366). Miklós fia, alvajdai ember (1348: CDTrans III. 483. sz.). Gergely, Antal, Lukács és Miklós apja (1418: DL 31124. = ZsOkl VI. 1909. sz.). Kerelőn (KK) birtokos (1356: CDTrans III. 855. sz.). Királyi és vajdai ember (1359, 1372, 1374: uo. III. 1103. sz.; DRH. C. XIV. 162; иo. XIV. 467. = DF 253587). 51

- Mihály, Fehér vm. szolgabírája (1478-1479). Királyi ember (1468: DL 30211). 52

- Osvát, Fehér vm. alisp. (1494). Vajdai, nádori, alvajdai ember (1493, 1520, 1507: DL 26453, 31030, 30071). 53

Sülyei (gáldtői, FH; Iczkovits 62; Csánki V. 958-959)

- Illés, Fehér vm. szolgabírája (1471). 52

sülyei cs: Volkányi

Swerch-i (v. sztrigyi Swarch) János magister, erd. alvajda, Fehér vm. isp. (1396-1401). Fiai Sztrigyen (HD) bir- 
tokosok (1426: DL 27856); vö. Csánki V. 206, 237. 51

Szakácsi (KSz; Csánki I. 563)

- [Nagy] György deák, Doboka vm. alisp. (1493-1494). Olykor Szakácsi Nagy Györgyként említik (1486: DL 27944, 1495: DL 27981). Báldoni (KA) Nagy Mátyás fia: szakácsi Nagy Bálint és Keceli Tamás leányának: Margitnak a fia, Rátoni Nagy Albertné Ilona és Szodorói Albertné Katalin testvére, Magyarkecelen birtokos (KA, 1498: KmJkv II. 3054. sz.). Iklódi Balázs leánya: Kata férje, János apja, 1493-ban füzesi, oláhpénteki és poklostelki jószágrészekkel kapcsolatosan egyezséget köt Iklódi Benedekkel (Kádár-Tagányi III. 483). 1498-ban Kecel (KA) iktatásának ellentmondott (1498: ErdKLt 758. sz.; idézi Kádár-Tagányi III. 613). Szakácsin birtokos (KSz, é. n., TelOkl II. 43). 1479 k. Doboka vm. alispánjával, szolgabírájával és több más nemessel együtt osztályt hajt végre a megyében (KmJkv I. 2272. sz.). Királyi ember (1495: DL 27981). Ügyvéd (1493: DL 27560). 44

Szakál (abosfalvi, KK; Csánki V. 960)

- Imre, Küküllő vm. szolgabírája (1478-1479). Ügyvéd (1468: KmJkv I. 1826. sz.). 82

Szalmás (Salmas) Miklós, Torda vm. szolgabírája (1430). 86

Szalmatercsi (NO; Csánki IV. 118)

- János, Doboka vm. isp. (1451), Kolozs vm. alisp. (1450-1451). Nevéből ítélve Nógrád vm.-i nemes. 40, 75

Szalók nb. Miklós, Küküllő vm. szolgabírája (1344) 1. Darlaci Miklós

Szalók nemzetség: Baládfi, Cikmántori, Darlaci, Kendhidai

szamosfalvi cs: Gyerőfi, Mikola, Sándor

Szancsali (KK; Csánki V. 585, 960)
- Mihály, Kolozs vm. isp. (1458). Felesége: Sárdi László leánya: Ilona (1453: KmJkv I. 1108. sz.). 75

szancsali cs: Sulyok

Szarkadi (TD; Csánki V. 813-814)

- László (Miklós fia), Torda vm. szolgabírája $(1409,1418,1421)$. János, Tamás, László és Szentmihályi Péterné Dorottya apja (1417: ZsOkl VI. 352. sz.; Csánki V. 813). 86

\section{Szászzsombori (DO)}

- Salatiel, Doboka vm. szolgabírája (1511-1515). Péter, Bálint és László apja; Szászzsomboron birtokos (KmJkv II. 3681. sz.), Galacon zálogbirtokos (1518: uo. II. 3605. sz.). 1516-ban lemondott a szolgabíróságról (WassLt 617. sz.). Vajdai és királyi ember (1511, 1518: иo. 568. sz.; DL 27411). 45

Szavai (DO) László (Márk fia), B-Szolnok vm. isp. (1392). 1377-ben vajdai kiküldött (DRH. C. XV. 110, 189). A család Pélen és Sállakán (ZD) is birtokos (1371: uo. XIV. 79, 88). 26

Székely (inakfalvi, Aranyosszék; Csánki V. 590)

- Tamás, Kolozs vm. isp. (1458). Valószínűleg Székely Tamás Kolozs vm.-i alispánnal azonos. 75

Székely (kercsedi, de Kerczet, Aranyosszék [?])

- Tamás, Kolozs vm. alisp. (1465-1466). L. fentebb. 76

\section{Székely (kisesküllői; DO)}

- Sebestyén, Doboka vm. isp. (1548). Felesége: Zsombori Klára (1552: KmJkv II. 5167. sz.). Kis- és Nagyesküllőn birtokos (1537, 1553: uo. II. 4597, 5238. sz.), Kolozs vm.-ben zálogbirtokos (1548, 1551: uo. II. 4903, 5067. sz.), egregius (1545: uo. II. 4852. sz.). 1554. évi végrendelete ismeretes (uo. II. 5276. sz.). 47 
Székely (marói, DO)

- Péter, Doboka vm. alisp. (1414). 36

Székely (szentegyedi, DO; Csánki V. 591)

- Lőrinc Doboka vm. szolgabírája (1481-1484), Doboka vm. alisp. (1487). Cegei Wass Margit férje (1505: WassLt 530. sz.; 1477: DL 26427). Szentegyeden zálogbirtokos (DO; 1482: KmJkv I. 2344. sz.), Pulyonban (DO; WassLt 568. sz.; KmJkv I. 2442. sz.) és Szentmiklóson (DO, 1476: DL 37304) birtokos. Szentegyedi és pulyoni birtokát emberölés miatt II. Ulászló kir. eladományozta (1499: DL 30303). Fogott bíró (1497, 1501: WassLt 492, 503. sz.), ügyvéd (1503, 1508; ио. 517, 544 sz.), vajdai ember (1496: TelOkl II. 427; 1500: DL 28662). 1514-ben jobbágy famulusát említik (WassLt 610. sz.). 1505-ben megírt végrendeletében a szentegyedi egyháznak adományt tett, másokra pulyoni házát és szőlőit hagyta (uo. 530. sz.); gyóntatója a szentegyedi plébános volt (uo. 630 . sz.). †1511. XI. 29. e. (uo. 568. sz.). 43

- István Doboka vm. alisp./isp. (1446-1452), 1452-ben B-Szolnok vm. alisp. (1452). Herepei Márk erd. alvajda familiárisa (1450: KmJkv I. 805. sz.). Ügyvéd (1446, 1449, 1452, 1459: uo. I. 571, 707, 1055, 1394. sz.), vajdai ember (1449: uo. I. 659. sz.; 1461: DL 27487). Talán azonos Szentegyedi Istvánnal (András fiával), aki Doboka vm. szolgabírája 1453-1455 között. $27,39-40$

\section{Székely (TD)}

- Miklós, Torda vm. isp. (1494). Vélhetőleg szentiváni Székely Mihály fiával: Miklóssal azonos, akinek örökjogú részbirtokai [Vajda]szentiványon, Szakálon és Szengyelen (TD), zálogos jószágrészei pedig Faragón (KL), Némán és Rücsön voltak (TD, 1492,
1513: KmJkv II. 2793, 3713. sz.; 1491: TelOkl II. 176). 89

Szengyeli (TD; Csánki V. 817-818)

- Domokos, Torda vm. szolgabírája (1444, 1453). Szengyelen (TD) birtokos (1468: KmJkv I. 1804. sz.). Királyi ember (1468: DL 26413), ügyvéd (1471: KmJkv I. 2020. sz.). 87-88

- László, Torda vm. szolgabírája (1401). 86

- Mátyás, Torda vm. szolgabírája (1447, 1462-1463), Torda vm. alisp. (1469). Benedek fia, András, Benedek, Klára és Margit apja (1467: KmJkv I. 1725. sz.). Szengyelen birtokos (TD; 1447: DL 30185; 1468: KmJkv I. 1804. sz.), vajdai ember (1467: DL 31170), ügyvéd (1468: KmJkv I. 1806. sz.). Rédei János erd. alvajda familiárisa (1469: uo. I. 1851. sz.). 87-88

- Mátyás, Torda vm. szolgabírája (1503, 1512). 89

- Miklós, Torda vm. szolgabírája (1449). Lőrinc apja, 1459-ben néhai (KmJkv I. 1347. sz.). 88

szengyeli cs: Sárosi, Tót

Szentegyedi (DO)

- András (Mihály fia), Doboka vm. szolgabírája (1397-1401, 1414, 1416-1420, 1423). Pál apja (1435: DL 44023). Vélhetőleg $\rightarrow$ Mihály szolgabíró fia. Szentegyeden birtokos (1407: WassLt 276. sz.), Császáriban zálogbirtokos ( $\mathrm{ZsOkl} \mathrm{IV.}$ 806. sz.); 1392-ben vajdai, 1410-ben alvajdai kiküldött (WassLt 217, 286. sz.), ügyvéd (1398: uo. 231. sz.). 35-37

- István (András fia), Doboka vm. szolgabírája (1453-1455). Vélhetőleg $\rightarrow$ András szolgabíró fia. Rápolti Anna férje (HD, KmJkv I. 1024. sz.). Talán azonos az ekkor élt szentegyedi Székely Istvánnal (1449: uo. I. 707. sz.), aki alisp. és ispán 1446-1452 között. 41 
- Mihály magister (Jakab fia), Doboka vm. szolgabírája (1367-1372). Azonosítására lásd WassLt 158. sz. (1372). Vélhetőleg $\rightarrow$ András szolgabíró apja. Alvajdai, vajdai kiküldött (1366, 1369, 1372: uo. 142, 163. sz.; DRH. C. XIII. 635). 34

szentegyedi cs: Székely, Valkai

Szentemagócs nemzetség: Kömörői

Szentes (frátai, KL; Csánki V. 592-593)

- György, Kolozs vm. szolgabírája (1458). Máté, Barnabás, Fülöp és Erzsébet apja (1469: KmJkv I. 1857. sz.). Magyar- és Oláhfrátán, Botházán (KL), Márkházán (DO) birtokos (1440, 1442: иo. I. 230, 450, 471. sz.). Ügyvéd (1440: uo. I. 281. sz.). 75

Szentgyörgyi (BSz; Szentgyörgy = Vízszentgyörgy, ma puszta Széplak közelében).

- Miklós, B-Szolnok vm. szolgabírája (1443). László fia (1440: KmJkv I. 273. sz.), Gergely apja (1440: uo. I. 274. sz.). Szentgyörgyön és Széplakon (BSz) birtokos (1440: uo. I. 273. sz.). Ügyvéd (1442, 1453: uo. I. 458, 1090. sz.). 27

Szentgyörgyi (HD; Csánki V. 137, 229235)

- István, Hunyad vm. szolgabírája (1439). 56

- János (Mihály fia: János fia) Hunyad vm. szolgabírája (1410-1413). 56

Szentgyörgyi (szopori, KL; Csánki V. 593; Szentgyörgy = Marosszentgyörgy)

- György, Kolozs vm. szolgabírája (1488, 1492). Barnabás fia (1486: SzOkl I. 259). Felesége: méhesi Tót István leánya: Márta (1482: DL 26925; KmJkv I. 2408. sz.). Egregius, Kolozs vm.-i birtokokkal való megadományozása ellen 1492-ben tiltakoznak (uo. II. 2818. sz.). Szoporon és Őrön (KL) birtokos
(Csánki V. 593). Királyi ember (1493: KmJkv II. 2845. sz.). 77

Szentgyörgyi (TD; Csánki V. 819; Szentgyörgy = Csapószentgyörgy)

- János, Torda vm. szolgabírája (1461). 88

- Mátyás, Torda vm. szolgabírája (1447). Valószínüleg elírás Szengyeli Mátyás Torda vm. szolgabírájának (1447, 1462-1463) neve helyett. 87

szentgyörgyi cs: Császár, Csegedi, Porkoláb

Szentimrei (FH, Csánki V. 235)

- András deák (litteratus), Hunyad vm. isp., Hunyad vár várnagya (1520-1529). 1509-ben Szentimrei (másként morvaországi, de Moravia) András az erd. vajda dévai és aldiódi jövedelmeinek kezelöje, Lövöld (Moson vm.) birtokosa, egregius (DL 30339, idézi Csánki V. 235). 1509-ben bevezetik Középszilvás és Alsószilvás (HD) birtokokba (DL 27590). Hunyad vár birtokosának, Brandenburgi Györgynek a familiárisa (Pataki: Hunedoara 177). †1530-ban (uo. 242-243). 62

Szentiváni (TD; Csánki V. 819; Szentiván = Vajdaszentivány)

- Péter, Torda vm. szolgabírája (1430). Alvajdai ember (1427: TelOkl I. 490). 86

Szentiványi (BSz; Szentivány = Iklódszentivány)

- István (János fia), B-Szolnok vm. szolgabírája (1408). 27

szentiványi cs: Keresztesi

Szentkirályi (de Sancto Rege; FH; Csanád nb.; Szentkirály = Enyedszentkirály; Iczkovits 62-63; Györffy II. 186)

- Gergely comes, Fehér vm. szolgabírája (1303). 1291-ben az alvajda helyettese mellé kirendelt társbíró (CDTrans I. 479. sz.). 49 
- Gyula, Fehér vm. szolgabírája (1462). 52

- István comes, Fehér vm. szolgabírája (1320-1322). Enyedszentkirály (FH) birtokosa. $\rightarrow$ Sándor apja (CDTrans II. 875 , 1033. sz.). 50

- Sándor (István fia), Fehér vm. szolgabírája (1336-1339). $\rightarrow$ István comes fia (CDTrans II. 875, 1033. sz.). 50

Szentkirályi (székelyföldi, a Tuzsoni cs egyik ága, Simon fia: Semjén utódai [1366-1378]; TD; Csánki V. 820-821)

- Semjén, Torda vm. isp. (1440). 87

Szentkirályi (TD; Szentkirály = Pusztaszentkirály)

- „Oláh” (Wolach) János, Torda vm. alisp. (1440). Lehet, hogy azonos Szentkirályi János görgényi várnaggyal (1439: TelOkl II. 7). 87

szentkirályi cs: Sztrigyi

szentlászlói cs: Herepei

Szentmargitai (TD; Csánki V. 821)

- Miklós, Torda vm. szolgabírája (1408). 86

Szentmártoni (TD; Csánki V. 821; Szentmárton = Pusztaszentmárton)

- János (Beke fia), Torda vm. szolgabírája (1383). 86

- Miklós (Pál fia), Torda vm. szolgabírája (1392). Alvajdai ember (1378: TelOkl I. 182). 86

szentmártoni cs: Medvés

Szentmiklósi (DO). Talán azonos vagy rokon az ugyancsak Áronszentmiklóson birtokos szentmiklósi Károly családdal (1. ott is).

- Ferenc, Doboka vm. szolgabírája (1407). Alvajdai ember (1419: WassLt 354. sz., uo. 1423: 366. sz., 1424: иo. 371. sz., DL 27290; 1434: WassLt 426. sz.). Áronszentmiklóson birtokos (uo. 426. sz.; más néven: Aranyszentmiklós). 36
- Jakab, Doboka vm. szolgabírája (1390-1397, 1406). 35-36

szentmiklósi cs: Károly, Nagy

Szentpáli (KL; Csánki V. 598-599; Karácsonyi: Nemzetségek 290; Engel: Gen., Borsa nem 4. Szentpáli; Szentpál = Magyarszentpál)

- András (szentpáli), Doboka vm. isp. (1536, 1544-1546). Mihály és Gesztrágyi Erzsébet fia, Menyhért testvére (1514: KmJkv II. 3583. sz.), lelei Szilágyszegi Pál leánya: Margit (uo. II. 3814. sz.), majd Vitéz Katalin férje (uo. II. 4920. sz.); Borbála és Anna (uo. II. 3814. sz.), Erzsébet, Menyhért, András és János apja (második feleségétől: uo. II. 4849, 4920, 5342. sz.). Szapolyai János király familiárisa (Simon: Szapolyai familiárisai 241), követe (D-Gy.: Pöstyényi Gergelynek, Szapolyay János király 1526-1532. udvari kiadásáról vezetett jegyzéke. In: TTár 1898. 175). Szapolyai János erdélyi vajda (1510-1526) kíséretének tagjaként részt vett a hatvani országgyúlésen (1525: DL 24172, idézi Kubinyi: Szapolyaiak 191). Fogott bíró Kolozs vm.-i birtokperben, egregius (1519, 1524: KmJkv II. 3751, 4048. sz.), ügyvéd (uo. II. 3955, 4514. sz.). Szentpálon (uo. II. 3814. sz.), Koródon (mindkettő Kolozs vm.-ben; 1514: uo. II. 3583. sz.), Felegregyen, Szentpéterfalván (uo. II. 4400, 4442. sz.), Hídalmáson (uo. II. 4520. sz.), Szentmihálytelkén (KL; uo. II. 4849. sz.) birtokos; olykor hídalmási Szentpáliként említik (uo. 4583. sz.). Szentpálon kúriája és malma volt (uo. II. 3814, 4268. sz.). Nagyesküllőn nemesi kúriát (DO, 1524: uo. II. 4015. sz.), Papfalván (KL, 1535: uo. II. 4526. sz.) és Zsomboron (DO, 1536: uo. II. 4583. sz.) jószágrészt vásárolt. Andrásházi (KL) és fodorházi (DO) puszta jobbágytelkeit átengedte 
[Zsombor nb.] sólyomkői Menyhért Mátyásnak cserébe ez utóbbi nagyesküllői (DO) puszta jobbágytelkeiért (1524: uo. II. 4016., 4019, 4021. sz.), melyeket utóbb ugróci (DO) jobbágytelkekért és halastóhelyért cserélt el (1529: uo. II. 4274. sz.). Jenőn jószágrészt, udvarházat és malmot vett zálogba (DO, 1543: иo. II. 4786. sz.). Részt vett Szapolyai János erd. vajdának Havasalföldére vezetett hadjáratában (uo. II. 4268. sz.). I. János kir. (1526-1540) híveként megszerezte az I. Ferdinánd kir. pártján álló Valkaiak bábóci jószágrészét (DO; 1535: uo. II. 4520. sz.). Pénzen vásárolt erdélyi birtokai felét 1539-ben feleségére hagyta, minthogy állítása szerint annak anyai birtokai jövedelméből legalább annyi birtokot vásárolt, mint a szolgálataival szerzett saját pénzből (1539: uo. 4692. sz.). +1549. V. 7. e. (uo. II. 4920. sz.). $46-47$

- Gula/Jula comes (Artolph/Ortalph fia), Doboka vm. szolgabírája (1315) 1. Gyulai

- János, Kolozs vm. szolgabírája (1512, 1525). Szentpáli, ügyvéd (1523: KmJkv II. 3955. sz.). Vajdai ember (1528: uo. II. 4227. sz.). 78,80

- Lorand (Artolph/Ortalph fia), Doboka vm. szolgabírája (1315) 1. Gyulai

- Mihály, Kolozs vm. szolgabírája (1478, 1484, 1491, 1493). Pál fia (1472, 1474: KmJkv I. 2066, 2126. sz.). Koródon (KL) birtokos (uo. I. 2126. sz.). 76-78

- Pál, Doboka vm. isp. (1457), Kolozs vm. isp. (1458). Csicsó (BSz) várnagya (losonci Dezsőfi János familiárisaként, 1462: BánfOkl II. 51). Mihály, Tamás, Bálint apja (KmJkv I. 2136. sz.). Szentpálon (KL, olykor DO; uo. I. 1286. sz.; vö. uo. 609. sz.) és Koródon (KL) birtokos (uo. I. 483, 1287, 2136. sz.). 1439-ben az ugyancsak Kolozs megyében birtokos Valkói Benedek egyik társaként vérdíj fizetésére kötelezi magát egy gyilkosság kapcsán (uo. I. 153. sz.). Több alkalommal ügyvéd (uo. I. 305, 2113. sz.) vagy fogott bíró (uo. I. 1448, 2134. sz.). Vajdai kiküldött (1450: I. uo. 830. sz.; 1472: DL 27515), 1469-ben a tordai vajdai közgyülés egyik kiküldötte (uo. I. 1851. sz.), és a közgyűlés nevében a kolozsmonostori konventnél bevallást tett (uo. I. 1852. sz.). 41, 75

Szentpáli (KK; Csánki V. 964-965; Szentpál = Kerelőszentpál)

- László (Barabás fia) Küküllő vm. szolgabírája (1361). Ügyvéd (1364, 1367: DRH. C. XII. 206, XIII. 443-444). 81

Szentpéteri (KL; Györffy II. 373; Szentpéter $=$ Uzdiszentpéter $)$

- Mihály (Dénes fia) comes/magister, Kolozs vm. szolgabírája (1312-1314). Vélhetőleg azonos Szentpéteri Dénes fiával: Mihállyal (1305: CDTrans II. 46. sz.). Miklós magister telegdi föesperes, erd. kanonok testvére. Felesége: Agmánd nembeli Lőrinc leánya (1303: uo. II. 22. sz.). Magister, királyi ember (1321: uo. II. 406. sz.). 66

széplaki cs: Bordi

Szilágyi (bongárdi, DO)

- (Zylagy de Bangarth) János, Kolozs vm. isp. (1462), Torda vm. isp. (1462). Felesége: Girolti Ozsvát leánya: Klára, gyermekei: Bernát, Jób, Klára, Magdolna és Rwsynth (1471, 1491: KmJkv I. 2014, 2743. sz.). Bongárdon (DO) birtokos (1461: uo. I. 1547. sz.). Ügyvéd (1468: uo. I. 1833. sz.); eml. 1480 (uo. I. 2292. sz.); 1486-ban néhai (uo. I. 2596. sz.). 76,88

szilágyi cs: Nagy

Szilágytői (BSz)

- János, B-Szolnok vm. szolgabírája (1434-1435). 27 
- Lesták, B-Szolnok vm. szolgabírája (1397-1398, 1400). 26

- Miklós (Kozma fia), B-Szolnok vm. szolgabírája (1392, 1407). Alvajdai ember (1391: TelOkl I. 232). 26-27

Szilkeréki (BSz)

- András, B-Szolnok vm. szolgabírája (1452), Doboka vm. szolgabírája (1487). Ügyvéd (1453, 1482: KmJkv I. 1090, 1137, 1669, 2387. sz.). Szilkeréken (BSz) birtokos (uo. I. 2290. sz.), ahol nemesi kúriája volt (uo. II. 2720. sz.). Alsótőkön birtokos (DO, 1484: DL 27546). Vajdai ember (1464: DL 27491), 1468-ban tanúként idézik meg egy Doboka vm.-i perben (DL 27498). Somkeréki Erdélyi István ügyvédje (1476: TelOkl II. 122; 1479: uo. II. 139). Mihály fia, tőki Varsány Ambrusné Ágnes (KmJkv II. 2720. sz.), illetve Lőrinc dévai plébános apja (uo. II. 2514. sz.). Vö. Csánki V. 600. 27,43

- Demeter (Jakab fia), B-Szolnok vm. szolgabírája (1483-1485). $\rightarrow$ Jakab fia (1480: KmJkv I. 2290. sz.). 28-29

- István (Márton fia), B-Szolnok vm. szolgabírája (1370). Igrice (BSz) határjárásánál tiltakozást jelentett be (1379: DRH. C. XV. 572). 26

- Jakab, B-Szolnok vm. szolgabírája (1449). $\rightarrow$ Demeter és Fábián apja (1480: KmJkv I. 2290. sz.). Tévesen szerepeltette a szakirodalom Kolozs vm. szolgabírái között (Turul 82/2009. 1. sz. 8). 27

- János (Jakab fia), B-Szolnok vm. szolgabírája (1397-1398, 1400-1406). Vajdai ember (1380: TelOkl I. 197). 26

- Mihály, B-Szolnok vm. szolgabírája (1471). Szilkeréki birtokrész elidegenítése miatt tiltakozik (1480: KmJkv I. 2290. sz.). 1480-ban mikeházi Szilkeréki Mihályként említik (DL 27940). 28
- Miklós, B-Szolnok vm. szolgabírája (1471, 1495). Péter fia (1480: KmJkv I. 2290. sz.). 28-29

- Péter, B-Szolnok vm. szolgabírája (1455, 1468-1470). Miklós apja (1480: KmJkv I. 2290. sz.). 27-28

\section{Szilkeréki (tőki, DO)}

- Lukács, Doboka vm. szolgabírája (1494). 1497-ben Sárd birtokba (KL) való bevezetésekor ellentmond (KmJkv II. 3016. sz.). 1499-ben az alsótőki (DO) kúriáért perel (uo. II. 3091. sz.), Felső- és Alsótőkön zálogbirtokos (uo. II. 3926. sz.), leánya: Katalin Sárdon birtokos (uo. II. 3938. sz.). Alvajdai ember (1495: DL 27565). 44

szilkeréki cs: Mórici

Szilvási (KL; Csánki V. 601, 823; Szilvás = Mezőszilvás)

- Bertalan (András fia), Torda vm. isp. (1415). Testvére, illetve a fia: Balázs, 1448-ban a Vajdaszilvás, más néven Mezőszilvás (KL) nevü örökbirtokukat Farnasi Dénesnek vallják (1447, 1448: TelOkl II. 31-33; KmJkv I. 613, 628. sz.). 86

- Kristóf, Belsőszolnok vm. isp. (1515 e., DL 36607), vajdai nótárius (1487: DL 62927). Az erdélyi káptalan jegyzőkönyvének keltezetlen töredéke (DL 36607) szerint Nyíresi Tamás, az erd. káptalan jegyzője (1491-1514, DL 29547. és 29623) Nyíres (DO) birtokát Szilvási Kristóf Belsőszolnok vm.-i ispánnak és feleségének: Katalinnak kötötte le. Szilvási Kristófot 1515-ben vezették be az ekkor már néhai Nyíresi Tamás birtokába (DL 27605). 29

szilvási cs: Tót

Szindi (TD; Csánki V. 739)

- Sándor (Alexander, Sandur), Torda vm. szolgabírája (1366). Vajdai (1360: DRH. C. XII. 547, 552) és alvajdai ember; magister (1366: uo. XIII. 295). 86 
szindi Dancs 1. Tancs

Szomordoki (KL; Csánki V. 603-606)

- Domokos, Doboka vm. isp. (1446-1448), Kolozs vm. isp. (1449), Kolozs vm. szolgabírája (1451), Kolozs vm. alisp. (1461). Szucsáki (KL, KmJkv I. 752. sz.). Királynéi (1440: DL 30312) és vajdai ember (1449: KmJkv I. 659. sz.). Ügyvéd (1460: uo. I. 1429. sz.; 1461: uo. 1572. sz.). Péter fia (uo. I. 1148. sz.), Imre (uo. I. 474. sz.) és György testvére (uo. I. 563. sz.), Mihály, György és Antal apja (uo. I. 1544. sz.). Jószágrészei voltak a Kolozs vm.-i Szomordokon (uo. I. 1544-1545. sz.), Szucsákon (uo. I. 1148. sz.), Nádason (uo. I. 474, 563-564. sz.; 1482: DL 27069) és Karán (KmJkv II. 752. sz.). A Szucsákiakkal atyafi, Szucsákon jószágrészt szerez (uo. I. 209. sz.). 1449-ben vajdai ember (uo. I. 659. sz.). Fia, Mihály Vajdaházán és Felsőfüzesen birtokos (uo. II. 2586. sz.). 39-40, 75

- Imre, Kolozs vm. szolgabírája (1425, 1426-1427, 1434-1435). Szomordokon (KL) birtokos (1427: TelOkl I. 496). 73-74

- László (Domokos fia), magister, Kolozs vm. isp. (1396), Kolozs vm. szolgabírája (1398-1407). 70

szopori cs: Szentgyörgyi

Szőkefalvi (KK; Csánki V. 963)

- [---], Fehér vm. jegyzője (1536). 54

- Antal deák, Fehér vm. alisp. (1451). Deák (litteratus); Rédei János erd. alvajda Erdélyen kívüli familiárisa; itteni birtoka Szőkefalva, ahol kőtemplomot építtet (1468: KmJkv I. 1808. sz.). Kormányzói ember (1447: DL 29791). Lásd még Antal deák, Fehér és Küküllő vm.-ék nótáriusa (1438). 52

szőkefalvi cs: Kis

Sztári 1. Esztári
Sztrigyi (HD; szentimrei, FH; Szentimre = Marosszentimre)

- Péter, Fehér vm. isp. (1406), erd. alvajda (1404-1408). 1390-ben Hunyad vm. hatósága előtt ügyvédet vall (TelOkl I. 223). Az erd. kápt. tiltakozása szerint ennek Hunyad vm.-i birtokait el akarta pusztítani (1396: ZsOkl I. 4319. sz.). 1405-ben Zsigmond kir. (Nagy)denk (HD) birtokot neki adományozza (1405: TelOkl I. 303). Magister (1408: uo. I. 331). Felesége: somkeréki [Erdélyi] Miklós leánya: Katalin (1408, 1410: uo. I. 335, 362). Gyermekei: László szolnoki főesperes, Miklós, Imre és Ilona (1408, 1425: uo. I. 335, 475). 51

Sztrigyi (szentkirályi, FH; Iczkovits 62-63; Szentkirály = Marosszentkirály v. Enyedszentkirály)

- Dénes, Fehér vm. szolgabírája (1455). Ügyvéd (1452: KmJkv I. 1024. sz.). 52

Sztrigyi (sztrigyi, HD; mányiki, DO; novaji, gyekei, KL; Csánki V. 606. Mányikon birtokos család, 1395: Ub III. 158)

- György, Doboka vm. szolgabírája (1443-1446). Valószínüleg gyekei Sztrigyi Györggyel (KmJkv I. 100. sz.) azonos, aki 1444-ben fogott bíró Doboka vm.-ben (uo. I. 536. sz.), 1449-ben néhai (uo. I. 681. sz.). Fia: Imre Gyeke (KL) és Áronszentmiklós (DO) elfoglalása ellen tiltakozott (1449, 1461: uo. I. 695, 1577. sz.). 39-40

- István (novaji), Kolozs vm. szolgabírája (1449-1450). Fogott bíró (1448: TelOkl II. 37). 75

- István, Doboka vm. alisp. (1493). 1496-ban királyi ember (KmJkv II. 2989. sz.). Mányikon (DO) volt háza, 1523-ban néhai (uo. II. 3936. sz.). 44

- László (mányiki), Doboka vm. szolgabírája (1465-1470). 41-42 
- László, Doboka vm. szolgabírája (1530). Füzkúton (KL; KmJkv II. 4653. sz.) és Mányikon (DO) birtokos, ahol kúriája volt (1535, 1538: иo. II. 4523, 4652. sz.). 46

- Simon (mányiki), Belsőszolnok vm. alispánja (1519). Felesége: apáti Bojár András leánya: Ilona (1519: KmJkv II. 3707. sz.). Fiai: János és Péter (1523: uo. II. 3936. sz.). 1538-ban még élt (uo. II. 4654. sz.), 1549-ben néhai. Mányik, Apáti (DO), Báld, Kolozs, Oláhdellő, Magyardellő (TD), Szentbenedek, Medvés (FH) birtokban voltak jószágrészei (1549: uo. II. 4910. sz.). 29

Szucsáki (v. Szucsági, KL; Csánki V. 606-608)

- András (Miklós fia), Kolozs vm. szolgabírája (1360-1361). - A családnév nélkül említett Miklós fia: András azonosítására két lehetőség van: 1 . Szucsáki Bese fia: Miklós fia, vásárolt birtoka: Felsőmacskás (KL, 1357, 1358, 1368: CDTrans II. 911, 977, 1077. sz.; DRH. C. XIII. 515-516). 2. Szentmihálytelki „Chol” Miklós fia, magister, valkói (KL) nemes (1358: CDTrans III. 1022, 1030-1031. sz.; vö. Engel: Gen., Mikola rokonsága, 1. tábla: elágazás). 68

- János (István fia), Kolozs vm. szolgabírája (1351). Szucsáki István fia: János vajdai emberrel azonosítható (1348: CDTrans III. 450. sz.). János és Domokos apja (1361: TelOkl I. 119). Eskütárs (1353: CDTrans III. 716. sz.). 67

- János (Jakab fia), Kolozs vm. szolgabírája (1424, 1425). Ügyvéd (1423: TelOkl I. 467). 72-73

- János (László fia), Kolozs vm. szolgabírája (1408). Eml. 1409-ben (ZsOkl II/2. 7225. sz.). 70-71

- Mátyás, Kolozs vm. alisp. (1467). János fia. Felesége: Szucsáki László fia: Antal leánya: Márta (1460: KmJkv I.
1439). János [vajdai nótárius] apja (1499: uo. II. 3093. sz.). Szucsákon birtokos (1453: uo. I. 1088. sz.). Vajdai ember (1449, 1464: иo. I. 659, 1674. sz.), ügyvéd (1442, 1469: uo. I. 427, 1878. sz.), fogott bíró (1460, 1466, 1471: uo. I. 1448, 1702, 2041. sz.). Antal kolozsmonostori apát familiárisa és ügyvédje (1451: uo. I. 971. sz.). † 1480 e. (uo. I. 2295. sz.). 76

- Mihály (Antal fia), Kolozs vm. szolgabírája (1476). Szucsáki László fia: Antal fia (1460, 1474: KmJkv I. 1439, 2154. sz.). Vajdai ember (1464: uo. I. 1675. sz.), fogott bíró (1474, 1478: uo. I. 2156, 2253. sz.). 76

- Miklós magister, Doboka vm. jegyzője (1530). Szucsákon (KL; KmJkv II. 4227), Némán és Bekében (BSz) szerez birtokrészeket (1524: uo. II. 4031. sz.). 1519-ben a vajdai törvényszékről kiküldött ember (DL 30281). Deák (1525: KmJkv II. 4075. sz.); özvegye: Apollónia (1536: uo. II. 4575. sz.). 46

- „Porkoláb” Demeter, Kolozs vm. szolgabírája (1488) 1. Porkoláb

szucsáki cs: Nagy, Ravasz, Tatár, Vas

Szurda (túrcsáni, indali, TD; Csánki V. 823)

- István (Tamás fia), Torda vm. szolgabírája (1493-1494). Indali; Tamás fia, Indalon és Alsóegresen (TD) birtokos (1484: KmJkv I. 2482. sz.). Alvajdai és vajdai ember (1489, 1494: DL 28444, 27224). 89

Tabiási (eceli; KK; Csánki V. 966) János, Küküllő vm. isp. (1532). István fia. (1507: KmJkv II. 3394. sz.). Felesége: Bánffy Orsolya, gyermekei: János, Erzsébet, Katalin, Klára (1551: uo. II. 5074. sz.). Azonos azzal az almási Tabiási Jánossal (egregius), akinek Bábóc (DO), Bürkös (FH), Almás, Somogyom, Darlac, Pócstelke, Gyákos, Szénaverős, Bábahalma, Bord, Ko- 
csárd, Kissáros, Désfalva, Szentiván (KK) birtokokban volt jószágrésze (1526: uo. II. 4161. sz.). Eceli, Ördögkeresztúron (DO) birtokrészt vásárolt, Kovácsi (DO) birtokosa (1531, 1533: uo. II. 4359, 4421. sz.). 82

Tamás, Kolozs vm. isp. (1177 k.). 49

Tamásfalvi (KL; Csánki V. 608-613; Jakó Zs.: A Farnasi Veres család (Az 1467. évi erdélyi lázadás kutatásához). In: Emlékkönyv Imreh István születésének nyolcvanadik évfordulójára. Kolozsvár 1999. 215-217; Engel: Gen., Mikola rokonsága; 8. tábla: Bikali Tamásfalvi)

- Tamás (Gergely fia), Doboka vm. isp. (1419-1420). Olykor Bikali Tamás (KmJkv I. 1120, 1703. sz.) vagy Vitéz (uo. I. 1406. sz.; bikali Vitéz Tamás: uo. II. 2008. sz.) néven említik. Tamásfalvi Illés fia: Gergely fia, Miklós, Imre és György miles testvére $(\mathrm{ZsOkl} \mathrm{V}$. 897. sz.; 1434: DL 29245), György, Mihály, László és Gergely apja (KmJkv I. 188, 1120. sz.). Kolozs vm.-ben (Bikal, Kelecel, Szentmihálytelke, Topa, Valkó) birtokos család tagja ( $\mathrm{ZsOkl}$ I. 4936, 5433. sz.; TelOkl I. 498; ZsOkl II/2. 6449. sz.). Testvérének, György milesnek Isztriában, Friaulban (Itália) és Németországban teljesített szolgálataiért a család Zsigmond királytól új adomány címén kapta Háromfüld (Alsó-, Felső-, Középfüld, KL) birtokot (1415: ZsOkl V. 897. sz., vö. V. 958, 1057, 1079, VI. 46. sz.) és ugyancsak 1415-ben címeradományt (uo. V. 645. sz.). Tamás Bikalon (KL, KmJkv I. 497. sz.), Szentmihálytelkén (KL, 1451: uo. I. 993. sz.), Tancson (KL, ио. I. 1120. sz.), Háromfüldön (KL, иo. I. 1703. sz.) birtokos; osztályos testvéreivel együtt birtokolja Sebesvárt (KL, 1452: DL 29276) és velük együtt telepítette Nyírszeg (KL) falut (KmJkv I. 674. sz.). 1444-ben a családtagok érvény- telennek nyilvánították azt a korábbi egyezségüket, miszerint az érdemeikért kapott birtokaikat egyenlően elosztják (uo. I. 521. sz.; DL 44400). †1466. XI. 13. e. (KmJkv I. 1703. sz.). 37 tamásfalvi cs: Bikali

Tancs (Tanch, Danch; szindi, TD; Csánki V. 823-824)

- Péter, Torda vm. szolgabírája (1446-1448). 87

Tárkányi Dénes, B-Szolnok vm. isp. (1443) 1. Boda

Tatár (Thatar d, kerelői, KK; Csánki V. 967)

- Lőrinc (Bálint apja), Küküllő vm. szolgabírája (1416). Kerelőn (KK) birtokos (1410: DL 27633). 82

Tatár (szucsáki, KL; Csánki V. 614)

- (Tatar d) Péter, Kolozs vm. szolgabírája (1410, 1415-1417). Alvajdai ember (1419: ZsOkl VII. 513). † 1423. e.; Katalin apja (uo. X. 418. sz.). 71-72

Tátéi (FH; Iczkovits 62)

- László ( $\rightarrow$ Márton fia), Fehér vm. szolgabírája (1363-1366). Alvajdai ember (1367: DRH. C. XIII. 363, 411), királyi ember (1369: uo. XIII. 577). 51

- Márton (Kemin fia), Fehér vm. szolgabírája (1339-1342). Péter és $\rightarrow$ László apja (1369: DRH. C. XIII. 661). Comes, Bökényszegen (FH) birtokos (1354: CDTrans III. 751. sz.), vajdai közgyülésen ülnök (1344: uo. III. 227. sz.), vajdai ember (1343, 1356: uo. III. 121, 864). Vö. LtKözl 55/1984. 2. sz. 120. (Jakó Zs.). 50-51

Temesvári Vince, Hunyad vm. alisp. (1479), Hunyad vm. isp., Hunyad vár várnagya (1481-1483, 1489-1491). II. Ulászló királytól Hunyad vm.-i birtokokat kap adományba (1491: KmJkv II. 2737. sz.). Talán azzal a Bosory István fiával: Themeswary Vincével azonos, aki apjának Naghzechenn (AD) nevü 
birtokára vonatkozó oklevelek kiadását kéri 1484-ben az aradi káptalantól (DL 15294). Vö. Márki S.: Aradvármegye és Arad szabad királyi város története. Arad 1892. 292. 57-58

terenyei cs: Derencsényi

Tholdalagi 1. Toldalagi

Thorda, Torda vm. szolgabírája (1338 e.). 85

Tomaj nemzetség: Dezsőfi

Tomori (kövesdi, csúcsi, FH)

- István, kolozsmonostori jószágigazgató (1521), erdélyi alvajda (1523-1526), Fehér vm. isp. (1530). Lásd KmJkv I. p. 74-75. 54

Torockói (v. Thorotzkay; torockószentgyörgyi, TD; Csánki V. 827-829; Engel: Gen., Ákos nem 6. Torockói; ThLt 5-6)

- István (Elleus fia), B-Szolnok vm. alisp. (1349). 1344-ben a vajdai közgyülésen ülnök, Torda vm.-ből (CDTrans III. 227. sz.). Vajdai kiküldött (1355: uo. III. 785. sz.), fogott bíró (1355: uo. III. 788. sz.). 1366-ban ő és fiai: Elleus, Miklós, Elek és László magisterek I. Lajos kir.-tól pallosjogot kapnak (1366, 1373: DRH. C. XIII. 83-84; иo. XIV. 426-427). 25

Toldalagi (TD; Csánki V. 824-826)

- Barnabás, Torda vm. szolgabírája (1335). 85

- Tamás, Torda vm. szolgabírája (1446). Mihály apja ([1444]: KmJkv I. 532. sz.). Királyi ember (1439: DL 28378). 87

Tompa $(d)$ ([csombordi]; FH)

- Jakab, Fehér vm. szolgabírája (1408). Antal apja; csombordi (1418: ZsOkl VI. 1909. sz.). 51

tompaházi cs: Porkoláb

Tót (csomafáji, DO; Csánki V. 617)

- Gergely, Doboka vm. szolgabírája (1475, 1476-1481, 1487). Katalin férje (1462: DL 27489), $\rightarrow$ István, $\rightarrow$ László és Mátyás apja. Csomafáji Tót István fia (1454: KmJkv I. 1174. sz.). Örökölt birtoka Kide (DO; 1473: иo. I. 2088. sz.), Csomafáján birtokos (uo. I. 2383, 3047. sz.; 1462: DL 27489). Alvajdai ember (1468: KmJkv I. 1832. sz.; 1472: DL 27513), ügyvéd (1470: uo. I. 1994, 2061. sz.). †1498. IV. 30. e. (uo. II. 3047. sz.). 42-44

- György, Doboka vm. alisp. (1466). $\rightarrow$ Péter fia (KmJkv I. 562, 579, 629. sz.), János, Adorján és Csomafáji Pálné Veronika testvére (1446, 1448, 1461: uo. I. 563, 631, 1631. sz.), Koppányi János leánya: Katalin férje, Margit és Katalin apja (uo. I. 1503. sz.). Csomafáján (uo. I. 579, 1059, 1227, 1503. sz.), Koródon, Mérán (KL; uo. 579, 629. sz.) és Kidén birtokos (DO, uo. I. 1174. sz.), testvéreivel együtt a mérai plébániatemplom kegyurai (uo. 631. sz.). Ügyvéd (uo. I. 1429, 1631. sz.), királyi kúriából kiküldött királyi ember (1467: DL 27496, 27497, 27498). Vingárti Geréb János [erd. alkormányzó] familiárisa (1446: uo. I. 562. sz.). 42

- István, Doboka vm. szolgabírája (1530-1538). $\rightarrow$ Gergely fia, László és Mátyás testvére (1498: KmJkv II. 3047. sz.), János, Ferenc, György, Márta, Margit, Zsófia apja (uo. II. 3429, 3676. sz.). Csomafáján és Szentmártonmacskáson (DO; 1498, 1509: uo. II. 3047-3048, 3429, 3494. sz.) birtokos, utóbbit 1518-ban a Drágiaknak adta el (1518: uo. II. 3676. sz.). Bádokon jobbágytelket vett zálogba ([1530?]: uo. II. 4336. sz.). Testvéreivel együtt birtokolt mikeházi (BSz) kúriáját a Kodoriak kidei udvarházára és jószágrészére cserélték (1505: KmJkv II. uo. 3382, 3499. sz.). Vajdai (1499: TelOkl II. 233) és királyi ember (1514: uo. 3585. sz.). 46 
- László, Doboka vm. szolgabírája (1476 és 1479. III. 18. u. [?]). $\rightarrow$ Gergely fia (1498: KmJkv II. 3047. 1507: uo. 3429. sz.). Csomafáján (DO, 1477: uo. I. 2230. sz.), Kidén és Bádokon (DO, uo. II. 3429. sz.) birtokos. Fogott bíró (1484-1485: uo. II. 2514-2515. sz.), vajdai kiküldött (1479: DL 27535). 43

- Péter, Doboka vm. szolgabírája (1429-1430). $\rightarrow$ György, kidei Nagy Pálné Veronika, János és Adorján apja, akik Csomafáján, Mérán és Koródon birtokosok és a mérai templom kegyurai (KL; 1446, 1448, 1454, 1470: KmJkv I. 579, 629, 631, 1059, 1174, 1976. sz.). 38

Tót (méhesi, KL; szentannai, Marosszék; TD; KA; Csánki V. 617-618, 829)

- Balázs (szentannai), Torda vm. isp. (1493). $\rightarrow$ István (1466: KmJkv I. 1704. sz.) vagy Balázs fia (1488: uo. II. 2688. sz.). Tomb, Tuzson (KL), Dátos, Gerebenes, Sályi (TD), Benefalva és Szabad (Marosszék) részbirtokosa (1495: uo. II. 2951. sz.). Kraszna vm.-i ősi birtokai: Petenyefalva, Szentkeresztfalva, Alsó- és Felsősereden (1499: uo. II. 3088. sz.). 89

- István (méhesi) Kolozs vm. alisp. (1476). Felesége: Drági Zsigmond leánya: Potenciána, $\rightarrow$ Iklódi Márton özvegye (1476: KmJkv I. 2211. sz.; 1478: DL 26910). Szentannai Tót István Sebesvár $(\mathrm{KL})$ várnagya 1462-ben (SzOkl I. 192-193; az adatot Horváth Richárdnak köszönöm). Valószínűleg azonos néhai szentannai Tót Miklós fiával: Istvánnal, aki György, Miklós és Albert apja és aki Tuzson, Tomb (KL), Dátos és Lekence (TD) elfoglalása ellen tiltakozik (1462: DL 28524; Csánki V. 617). Alvajdai ember (1479: DL 26806). 76

Tót (szilvási, [BSz; Szilvás = Kecsedszilvás])
- István B-Szolnok vm. isp. (1476). 28

Tótházai (KL; Csánki V. 420)

- Benedek (Tamás fia), Kolozs vm. szolgabírája (1378-1381, 1388). 69

Tótprónai (TC; Csánki V. 617)

- Cherubin (Cherwbyn), Kolozs vm. isp. (1514-1521). Fehér vm.-ben birtokokat vásárol (1505: KmJkv II. 3359. sz.), zálogba veszi Gerendi Mátyás birtokait (1519: иo. II. 3714. sz.). Szentmártonon (TD) birtokos, Bányabükkön (KL), Egregyen, Kékesen, Nyárlón (DO) zálogbirtokos (1520: uo. II. 3783-3784. sz.; 1521: uo. II. 3798. sz.). A Turóc vm.-ben birtokos Szapolyai János erdélyi vajda (1510-1526) vagy Turóci Miklós erdélyi alvajda (1511-1516) familiárisa. 78-79

\section{Tóki (kidei, DO)}

- Gergely, Doboka vm. szolgabírája (1446-1449). Ügyvéd (KmJkv I. 126, 305. sz.). Kidén birtokos (DO, uo. I. 192, 361, 387 sz.), Alsó- és Felsőtőkön zálogbirtokos (uo. I. 442. sz.). Királynéi ember (1440: DL 30312). Fiai: Bálint és László (1471: uo. I. 2021. sz.), akik Kölesmezőn (KL) zálogbirtokosok (1470: uo. I. 1992. sz.) és Poklostelkén jószágrészt vásárolnak (1471: $u$. I. 2021. sz.). 40

tôki cs: Kis

Török (miskei)

- Ferenc, B-Szolnok vm. isp. (1468). 28

Török cs

- Ambrus, B-Szolnok vm. isp. (1470). 28

- András, Hunyad vm. isp. (1505). 60

Tötöri (DO; BSz)

- László (Myke fia), B-Szolnok vm. szolgabírája (1370). Tötöri (1371: DRH. C. XIV. 66). 26

túrcsáni cs: Nagy, Szurda

Túri (TD; Csánki V. 829-830) 
- Benedek, Torda vm. isp. (1512, 1527), erdélyi alvajda (1505-1507; Beszterce v lt, 1505. VII. 29., DF 247475; Suky cs 1t, 1507. II. 18. DF 255318). Csánon és Túron birtokos (1493: KmJkv II. 2898. sz.). A kolozsvári domonkos kolostor javára adományt tesz (1501: uo. II. 3215. sz.; túri birtokait annak adományozza, 1520: KmLt 389. sz. = DF 275302). Királyi ember (1514: KmJkv II. 3585. sz.). +1520 e. (KmLt 389. sz. = DF 275302). 89-90

- János (János fia), Torda vm. isp. (1366). János fia, Csánon és Túron birtokos (1366: DRH. C. XIII. 77). Vajdai ember (1366. uo. XIII. 126). Magister (1367: uo. XIII. 375). 86

Turóci (TC; Engel: Gen., Bogomér rokonsága, 3. tábla: Prónai/Turóci)

- Jakab (Beke fia), Kolozs vm. isp. (1381). Körös vm. isp. (1386). Turóc vm.-i nemes, Pál fia: Beke fia (Engel: Arch. II. 248). 69

Tuzsoni (KL, Engel: Gen., Tuzsoni /Szentkirályi/)

- Semjén fia: Mihály fia: János 1. János (Mihály fia), Kolozs vm. szolgabírája (1360-1361)

Tyukod nemzetség: Gerendi

Újbudai ([= Budai], KL; Csánki V. 447)

- Balázs, Kolozs vm. szolgabírája (1449-1450). István fia: György fia (KmJkv I. 1700. sz.). 75

- Bálint, Doboka vm. isp. (1453). Péter fia: István fia, Kolozs vm.-ben zálogbirtokos (KmJkv I. 1436. sz.). 1455-ben fogott bíró (uo. II. 1206. sz.). 41

újbudai cs: Kis, Nagy

Újfalusi (DO; Újfalu = Borsaújfalu)

- Lukács deák (litteratus), Doboka vm. jegyzője (1494-1495). Nevéből ítélve Újfalun lakos (DO, ma Borsaújfalu). 44
Vajcai (de Wayca) András, Hunyad vm. alisp., Hunyad vár várnagya (1479). 57

vajdaszentiványi cs: Földvári

Vajda, Doboka vm. isp. (1214-1219). 31

Vajda (várcai, KL; Csánki V. 423-424; Várca = elnéptelenedett település Incsel környékén)

- Vasile, Kolozs vm. szolgabírája (1530). Felesége: inaktelki Gyerőfi András leánya: Katalin (1543: KmJkv II. 4805. sz.). 80

Valkai (gyulai, DO; KL; Csánki V. 625; Engel: Gen., Mikola rokonsága, 9. tábla: Valkói és farnasi Veres)

- Márton, Doboka vm. alisp. (1510). Felesége: Koppány Péter leánya: Margit (1529: uo. II. 4277. sz.). Leányai: ősi Jankafi Miklósné Lúcia, bikali Vitéz Andrásné Ágnes, gyerőmonostori Kabos Imréné Fruzsina, Borbála, gyerőmonostori Kabos Kristófné Anna és istvánházi Istvánházi Györgyné, majd balázsfalvi Cserényi Györgyné Klára (uo. II. 4277, 4488. sz.). Családja Gyula birtokosa (DO; ZsOkl VI. 1655. sz.). Galaci (DO, 1502: KmJkv II. 3228 , 3332. sz.) és gyulai (DO, uo. II. 3917. sz.). Vajdai ember (1512, 1513: WassLt 576, 599. sz.). Jószágrészei voltak Szentmiklósmacskáson (DO), Valkón és Kelecelen (KL; 1518: KmJkv II. 3660. sz.; 1515: KmLt 363. sz.), Farnason (KL; KmJkv II. 3910. sz.). Kajlán és Szentandráson jószágrészt vásárol (uo. II. 3228. sz.). + 1529. XI. 11. e. 44-45

Valkai (szentegyedi, DO)

- István, Doboka vm. szolgabírája (1528). Péter fia, Gáspár, Boldizsár, János és Borbála apja. Jószágrészei voltak Gyula, Szentmiklósmacskás (DO), Valkó, [Kalota]újfalu és Kelecel (KL) birtokokban (1534: KmJkv II. 4488. sz.). 46 
- János Doboka vm. szolgabírája (1475-1479). Valószínűleg azonos azzal a Valkai Jánossal, aki 1479-ben jószágrészeket próbált megszerezni Méra, Andrásháza, Valkó, Kelecel, Koród (KL), Gyula és Macskás birtokokban (DO, uo. I. 2273. sz.). Királyi (1472: DL 27513) és vajdai ember (1482: DL 27543, 1487: DL 27915). $42-43$

- Péter, Doboka vm. szolgabírája (1498, 1510, 1515-1516). $\rightarrow$ János fia (1514: WassLt 610. sz.). Felesége: Szomolyai Péter leánya: Katalin (1524: KmJkv II. 4023. sz.); leánya: hídalmási Kántor Gáspárné, majd Hodosi FerencnéZsófia (1533, 1538: uo. II. 4403, 4648. sz.) és Dorottya, akiknek Szentandráson volt örökölt jószáguk és kúriájuk (uo. II. 4404. sz.). Fia: István (1534: uo. II. 4488. sz.). Egregius (1529: uo. II. 4241. sz.). Királyi és vajdai ember (1496, 1513: uo. II. 2989. sz.; WassLt 581. sz), fogott bíró (1503, 1507, 1515: KmJkv II. 3285,3399 , 3587. sz.), per tárgyalásán oklevelet olvas fel (WassLt 598. sz.). Gyulán, Szentmiklósmacskáson (DO) és Valkón (KL) birtokos (1529: KmJkv II. 4241. sz.). 44-46

Váradjai (Járai, FH; Engel: Gen., Váradjai/Járai; Lázár Miklós: Járai Péter alvajda és maradékai. In: Turul 2/1884. 152-156)

- Péter (Mihály fia), magister, erd. alvajda (1344-1349: CDTrans III. 233, 531. sz.), Fehér vm. isp. (eml.: 1348), Kecskés/Kecskekő vár (FH) várnagya (1346: CDTrans III. 335. sz.). Lackfi István erd. vajda (1344-1350) familiárisa, majd ugyanennek familiárisaként Körös vm. (Szlavónia) isp. (1351-1353), Nagykemlék vár (Körös vm.) várnagya (1351), szlavón vicebán (1352-1353); Lackfi Dénes és ifj. Lackfi Miklós erd. vajdák familiárisa- ként erd. alvajda (1359-1368), Hátszeg vár (HD) várnagya (1360: $D R H$. C. XI. 506-510). Lásd Engel: Arch. II. 254. Magister, részt vett a zárai hadjáratban, ennek jutalmaként megkapta Váradját (FH, 1346: CDTrans III. 338. sz.). + 1368-ban, I. Lajos kir. havasalföldi hadjáratában (Johannes de Thurocz: Chronica Hungarorum. I. Textus. Ediderunt: E. Galántai et J. Kristó. Bp. 1985. 181). 51

váraskeszi cs: Lépes

Várkői (Warkoy) Amade [= várkonyi Amadé; PO; Engel: Gen., Gútkeled nem 3. Amadé-ág]

- György, Kolozs vm. isp. (1499). Talán várkonyi Amadé Lénárd fiával: Györggyel azonos (1486, 1499, 1502: DL 90410, 48492, 48694). Pozsony vm.-i nemes. Bizonyára Szentgyörgyi Péter erdélyi vajda familiárisaként került Erdélybe. 78

Varsányi (de Warsan)

- Péter, Doboka vm. alisp. (1464). Talán annak a Varsányi családnak a tagja, amelynek egyik tagja 1491-ben Tőkön (DO) birtokos (KmJkv II. 2720. sz.). 41

Vas (Wass, cegei, DO; Csánki V. 626-627; Engel: Gen., Vas, Wass, cegei, szentegyedi; WassLt 27-115)

- Miklós magister, ifj., Kolozs vm. isp. (1347, 1349), Doboka vm. isp. (1361). Emuch fia: János fia (1331: WassLt 25. sz.). Felesége Aba nembeli Csente (Cente) János nővére volt (1356: uo. 110. sz.). Debreceni Dózsa erd. vajda famulusa (1329: uo. 22. sz.). Höltövény várában szolgál 1335-1344 között (uo. 36, 72. sz.), Kőhalom (al)várnagya (1357, 1358: WassLt 111, 117. sz.; DRH. C. XI. 247-248; WassLt 119. sz.). 1355-ben az erdélyi nemesek képviseletében ő járt közben I. Lajos királynál a vajdai közgyűlések ügyében (1355: DRH. C. X. 380-382). Cege, Keresztes, 
Mohaly, Nyíres, Pulyon, Szentegyed, Szentgothárd, Szentiván, Szilvás (DO) és Keszü (KL) részbirtokosa (1362: uo. XII. 102-103). Pecsétjén címert használt (DL 73688). 33, 67

- „Veres (Rufus)” Péter (János fia), Kolozs vm. alisp. (1359). Verres/Weres dictus (1354, 1359: WassLt 103, 121. sz.). Emic fia: János fia (1335: uo. 36. sz.). 1344-1348 között Lackfi Dénes allovászmestere (1344, 1348: uo. 72, 89. sz.), 1363-ban harcolt Boszniában (miles, 1363: uo. 130. sz.), 1368-ban ifj. Lackfi Miklós erd. vajda familiárisaként küküllővári várnagy. Részt vett a Havaselve elleni hadjáratban, ahol elesett (Johannes de Thurocz: Chronica Hungarorum. I. Textus. Ediderunt E. Galántai et J. Kristó. Bp. 1985. 181). 68

Vas (Was, szucsáki, KL; Csánki V. 627)

- Fábián, Kolozs vm. szolgabírája (1451?-1458). Felesége: budai Hamar Péter leánya: Ilona (KL, 1455: KmJkv I. 1197. sz.). Ügyvéd (1457, 1467: uo. I. 1283, 1720. sz.). Vö. DL 27039 (1463). 75

Vásári (BI; Engel: Gen., Vásári, 1, Rupolújvári)

- Miklós (Szügyi Loránd fia), erd. alvajda (1319-1320), Fehér vm. isp. (eml.: 1320). Loránd fia (1295: HOkm VIII. 347. = DF 278504, idézi: Engel: Arch . II. 255). 50

Vécsei (de Wece; AJ?) Balázs, Küküllő vm. isp. (1513). 1525-ben Vécsei Nagy Balázsként említik, ekkor Szapolyai János erdélyi vajda (1510-1526) kíséretének tagjaként részt vett a hatvani országgyűlésen (1525: DL 24172; idézi Kubinyi: Szapolyaiak 191). Szapolyai János király familiárisai között említik (Simon: Szapolyai familiárisai 241). 82
Veres (farnasi, KL; Engel: Gen.; Mikola rokonsága, 9. tábla: Valkói és farnasi Veres; Jakó Zs.: A Farnasi Veres család. Az 1467. évi erdélyi lázadás kutatásához. In: Emlékkönyv Imreh István születésének nyolcvanadik évfordulójára. Kolozsvár 1999. 231)

- Márton (János fia), Kolozs vm. isp. (1530-1533). János fia (1509: KmJkv II. 3507. sz.). Egregius (1540: иo. II. 4753. sz.). Farnas, Valkó, Füld, Szentmihálytelke, Tamásfalva stb. (KL) és Torda vm.-i jószágrészek birtokosa (1518: uo. II. 3653. sz.). Erdélyen kívüli szolgálatra megy (1518: uo. II. 3655. sz.), Szapolyai János erdélyi vajda familiárisa, havasalföldi hadjáratban vesz részt (1529 e.-re: uo. II. 4267. sz.). Koppányi Péter leánya: Magdolna férje, Detreh és Mindszent (TD) birtokosa (1520: uo. II. 3778). 1549-ben néhai (uo. II. 4923. sz.). 79

Veres (Veres, keresztúri, HD; Csánki V. 243)

- László, Hunyad vm. szolgabírája (1500). 60

Veres (Rufus, Weres, petlendi, TD; Csánki V. 836)

- Pál, Torda vm. szolgabírája (1449), fogott bíró (1449: KmJkv I. 710. sz.), ügyvéd (1450, 1452, 1474: uo. II. 785, 1058, 2131 sz.). Ilona és Márta apja, Torda vm.-ben birtokos (1452: uo. II. 1061. sz.). 88

Veres (Rufus) Miklós, B-Szolnok vm. szolgabírája (1407) 1. Girolti "Veres" Miklós

Veres (Rufus) Péter, Kolozs vm. isp. (1359) l. Vas Péter

Vessződi (FH; néhai gáldtői Vessződi György birtokai 1515-ben: Kisenyed, Farkastelke, Hidegvíz, Vessződ, Bólya, Ingodály, Salkó, Sálfalva, Ivánfalva, Kövesd; FH; DL 63007)

- Elek, Fehér vm. alisp. (1525). 54 
- János, Fehér vm. alisp. (1435). 52

- János, Küküllő vm. alisp. (1518 e.). 82

Vízközi (de Wyzkez) András, Hunyad vm. isp., Hunyad vár várnagya (1488). 58

Volkányi (valkányi, sülyei, Felsőfehér vm.; 1487-től Segesvárszék: DL 36636)

- Miklós, Fehér vm. szolgabírája (1478-1479). Sülyei (1470: KmJkv II. 1860. sz.). György apja (1484: TTár 1907. 101. = DF 253727). A Torockói család ügyvédje (1470: DL 28535). 52

Wass 1. Vas

Zagyvafői (NO; Kacsics nb., várbirtokuk: Zagyvafö, vö. Csánki I. 111; Engel: Gen., Kacsics nem, 2. tábla: Zagyvaföi)

- László magister (Miklós fia), Hunyad vm. isp., dévai várnagy (1395), borsodi alisp. (1405), sárpataki (TD) officialis 1411-ben (TelOkl I. 372). Pető fia: Miklós fia. Zsigmond királlyal együtt Morvaországban fogságba esett, testvére váltotta ki (1414: $\mathrm{ZsOkl}$ IV. 2361. sz.; 1393?: uo. I. 3124. sz.; azonosítás és az idézett adatok forrása: Engel: Arch. II. 261). 56

Zakariás (felpestesi) 1. Felpestesi Zakariás

Zakeus, curialis comes, Doboka vm. (1213). 31

Zalai (TD?; Csánki V. 796, 837)

- (d) Pál, Torda vm. alszolgabírája (1310). 85

\section{Zalai (bongárdi; DO)}

- Gáspár, Doboka vm. szolgabírája (1544-1546)

Zalai (cegői, zalaházi, DO; Csánki V. 635-636; Kádár-Tagányi II. 498; Zalaháza = eltünt település Esküllő közelében) 47
- László, Doboka vm. választott esküdtje (1489). István fia (1451: KmJkv I. 931. sz.). Felesége: Kewsla, aki férje halála u. köblösi Teke Balázs felesége; István, János (1499: DL 27577), László, Kecseti Lászlóné Magdolna és Anna apja (1503: DL 27234; vö. KmJkv II. 3533. sz.). Cegői Zalay (uo. II. 2405. sz.) vagy zalaházi Zalay László (uo. I. 2343. sz.; 1464: DL 27177) néven említik. Zalaházán (KmJkv I. 929. sz.), Szentmártonmacskáson (1451: uo. I. 931. sz.) birtokos. Katonán (KL) udvarháza volt (1493: Entz 313). Királyi (1464: DL 27490; 1475: DL 27055), vajdai (1489: DL 27379) és alvajdai ember (1449: KmJkv I. 659, 671. sz.), ügyvéd (uo. I. 1283. sz.). Zálogos vagy vásárolt jószágrésze volt Kékes (DO; 1450: uo. I. 795. sz.), Csomafája (DO; uo. I. 2230; II. 3533. sz.), Felsőbréte és Kócs (BSz; 1477: uo. I. 2246. sz.), Bábóc (DO, 1477: uo. I. 2249. sz.), Szilvás (1482: KL, uo. I. 2343. sz.), Régen, Magyarrégen (TD), Dedrád, Széplak, Kissajó birtokokban (KL; 1483: uo. I. 2450. sz.; 1474: DL 27199). Csépán és Priszlop (BSz) zálogbirtokosa (1481: TelOkl II. 145). †1499. XI. 15. e. (DL 27577). 44

zalai cs: Nagy

Zalasdi (HD; Csánki V. 244)

- János, Hunyad vm. isp., Hunyad vár várnagya (1507). 60

Zbugyai, Izbugyai 1. Ezbwwdy

Zicsi, Gál magister, Belsőszolnok vm. isp. (1355) 1. Járai Gál

Zolardus/Zorad, B-Szolnok vm. isp. (1483-1485). 28

Zutori ([= középlaki, középlaki Kémeri], KL; Csánki V. 529-534)

- István deák, Doboka vm. alisp. (1510). Siroki Mátyás leánya: Borbála férje, István és Erzsébet apja. 1555-ben egy kolozsvári ház elidegenítése ellen 
tiltakozik (KmJkv II. 5353. sz.). Zutoron (KL) birtokos (1538: uo. II. 4637. sz.; vö. Csánki V. 636). Bócon (KL, elnéptelenedett település Magyarnádas közelében) zálogjószágot szerez (1508: KmJkv II. 3450. sz.). 44

Zsámboki Simon erd. alvajda (1333-1336), Fehér vm. isp. (eml.: 1336). Zsámboki (1361: DRH. C. XII. 18-19; idézi: Engel: Arch. I. 11). 50

zsombori cs: Móré, Nagy, Roth

Zsombor nemzetség: Ördög

Zsombori Salatiel, Doboka vm. szolgabírája (1511-1515) 1. Szászzsombori Salatiel

Zsombori (v. Sombory, DO; Csánki V. 579; Zsombor = Magyarzsombor)

- Mátyás, Doboka vm. szolgabírája (1487). Vélhetőleg azonos Zsombori Kis (Parvus) Mátyás alvajdai kiküldöttel (1479: DL 27535). 43

- Pál (Pető fia), Doboka vm. szolgabírája (1380). Vajdai kiküldött (1380: DRH. C. XV. 700). 34

Zsombori (v. Sombory DO; Engel: Gen., Brassói-rokonság, 1. tábla: Zsombori, Sombori; Zsombor = Szászzsombor)

- László, Doboka vm. szolgabírája (1548). Péter fia (1540: KmJkv II. 4737. Sz.). 47

- Péter, Torda vm. isp. (1499). Szentgyörgyi Péter erd. vajda familiárisa; ispáni kinevezéséről értesítés Torda vm.-hez 1499-ből maradt fenn (Sombory lt: DL 65442). Gergely [gyalui várnagy] fia (1473, 1474: DL 65430; KmJkv I. 2124. sz.). Első felesége: Zsófia (uo. II. 2342. sz.). Gyermekei: Péter, Benedek, Mihály, János, Borbála, Cakó Benedekné Margit, Klára és Fruzsina (1492, 1507, 1520, 1526: ио. II. 2772, 3439, 3758, 3796, 4139. sz.). 1519-ben néhai (uo. II. 3742. sz.). Özvegye: Klára (1520: uo. II. 3796. sz.). Egregius (1507: uo. II. 3438. sz.). Somi Gáspár ud- varbírája, intézője és jövedelmeinek kezelője (1520: uo. II. 3758-3759. sz.). Ügyvéd (1482: uo. I. 2379. sz.). Esküllő, Kisesküllő, Galponya, Örmező, Farkasmező, Kendermező, Borzova, Szászzsombor, Rákos (DO) és Ajton (KL) birtokokban voltak jószágrészei (1473-1508: DL 65430, 65426, 65429, 65430; KmJkv II. 2666, 2670, 2806, 3364, 3439, 3482. sz.). Magyaregregyen (DO) birtokrészt vásárol (1507: uo. II. 3438. sz.). A drági (1488: uo. II. 2669. sz.) és az őrmezői vám birtokosa, II. Ulászló kir. évenkénti sóadományban részesíti (1496: DL 65441). 1482-ben, római zarándoklata előtt végrendelkezik (KmJkv II. 2342. sz.). Familiárisait említik (1482, 1524: uo. I. 2342. sz.; II. 4003. sZ.). 89

Zsuki (KL; Csánki V. 580-584; Engel: Gen., Agmánd nem 2. Zsuki, Suky; Daróczi Z.: A Suky család leszármazása a XVI. sz. közepéig. In: Turul 26/1908. 139-142; Petrichevich-Horváth E.: A Suky család címereslevele. In: Turul 50/1936. 69-77)

- István comes, Kolozs vm. szolgabírája (1312-1314). Demeter fia, Lénárt, László, Sandur és György apja (1332: CDTrans II. 746. sz.). Zsukon birtokos $(1312,1326$, a rokonság birtokosztálya 1332-ben: uo. II. 195, 563, 569, 746. sz.). Királyi ember (1332: uo. II. 760. sz.). 66

- János comes (Domokos fia), Kolozs vm. szolgabírája (1340-1349, 1353-1359, 1363-1367). Comes (1342: CDTrans III. 117. sz.). Domokos fia, Zsuk birtokosa (1326, 1332: uo. II. 563, 746. sz.). 1344-ben, majd 1371-ben, rokonaival együtt, tiltakozik Felekfark nevü, utóbb Györgyfalvának elnevezett (KL) birtokuk elfoglalása ellen (uo. III. 231. sz.; TelOkl I. 169-170). Birtokai: Zsuk, Szovát, Sármás és 
Kötelend (KL, 1348, 1354, 1359, 1360: CDTrans III. 482, 755, 1102. sz. DRH. C. XI. 457, 473). 1344-ben vajdai közgyülésen ülnök (CDTrans III. 227. sz.). Vajdai és alvajdai ember (1351, 1364: uo. III. 628. sz.; DRH. C. XII. 249). 67-68

- Mihály magister, B-Szolnok vm. isp. (1329-1332), Kolozs vm. isp. (1324), Torda vm. isp. (1338). Albert fia, $\rightarrow$ Miklós testvére, szolgálatai jutalmául I. Károly kir.-tól megkapja Pálostelkét és Omboz erdőt (DO, 1320, 1324: CDTrans II. 348, 353, 360, 472. sz.). Szovát, Zsuk, Sármás (KL) birtokosa (1312, 1326, 1332, 1335: uo. II. 195, 563, 569, 746, 852. sz.). Vajdai ember (1320: uo. II. 362. sz.). 1329-ben Szécsényi Tamás erd. vajda szolgálatából Szécsi András erd. püspökhöz szegődik és ennél tárnokmesterséget vállal; birtokait ekkor a vajda felprédálja (1329: uo. II. 658. sz.). Eml. 1342 (uo. III. 112. sz.). Vö. EM 67/2005. 79-80. 25, 66, 85

- Miklós (Albert fia), Kolozs vm. isp. (1339). Albert fia, Barnabás, Mihály, Dávid és Illés apja (1348: CDTrans III. 489. sz.). Albert fia, $\rightarrow$ Mihály testvére, szolgálatai jutalmául I. Károly kir.-tól megkapja Pálostelkét és Omboz erdőt (DO, 1320, 1324: CDTrans II. 348, 353, 360, 472. sz.). Zsuk, Ábeltelke, Sármás, Omboz (KL) birtokosa (1326, 1332, 1335: иo. II. 549, 563, 569, 575, 746, 852, 857. sz.). 1326-ban serviensét említik (uo. II. 579. sz.). Magister; a reászállott [Póka]keresztúr (TD) birtokot az erd.-i püspökségnek adja (1339 u.: uo. II. 1048. sz.). 1343-ban özvegyét, Erzsébetet említik (uo. III. 132. sz.). 67

- Pál, Kolozs vm. isp. (1494). A kolozsmonostori konventnél tett bevallásban: Paulus Farky, comes comitatus de Colos, 1494: Kemény cs malomfalvi lt, DF 257836). Valószínü, hogy a név elírás, helyesen pedig Suky lenne;
Zsuki Pál kolozsi ispánságát azonban semmilyen más adat nem támogatja. 77 
EME 


\section{EME}

REZUMAT

Lucrarea de față conține listele arhondologice ale celor şapte comitate transilvănene aflate sub cârmuirea voievodului Transilvaniei (I. Solnocul Interior, II. Dăbâca, III. Alba, IV. Hunedoara, V. Cluj, VI. Târnava, VII. Turda) pentru perioada anterioară anului 1542. Aceste liste conțin, pentru fiecare dintre comitatele menționate, numele comitelui (dacă există şi pe cel al vicecomitelui), a celor doi juzi nobiliari, precum şi a notarilor comitatenşi, informații la care se adaugă precizări privind perioada în care aceştia îşi îndeplineau funcția. Arhondologia Ungariei medievale, alcătuită de către Pál ENGEL, pentru perioada 1301-1457 (Magyarország világi archontológiája 1301-1457, vol. I-II, Bp. 1996) conține şi datele referitoare la comiții ardeleni din acea perioadă. Datele respective au fost însă reluate şi completate cu noi detalii (şi desigur, cu informațiile referitoare la juzii nobiliari).

Comiții comitatelor transilvănene erau desemnați de către regele Ungariei, iar de la începutul secolului al XIV-lea de către voievodul Transilvaniei din rândul slujbaşilor (familiarilor) proprii, provenind de regulă din familii nobiliare ardelene. În cele mai multe cazuri nu dețineau de-a lungul „carierei” lor alte funcții de importanță politică, ocupând din acest punct de vedere un statut inferior față de comiții celorlalte comitate (în Ungaria, în comitatele din afara Transilvaniei şi Slavoniei comiții erau numiți de către rege pe tot parcursul evului mediu şi foarte des, funcția era îndeplinită de către demnitari importanți).

În ceea ce-i priveşte pe juzii nobiliari, alegerea lor revenea în fiecare comitat nobilimii comitatense, care îi selecta întotdeauna din rândul familiilor cu posesiuni în comitatul respectiv. O bună parte a comiților şi juzilor nobiliari erau recrutați din rândul aceloraşi familii nobiliare ardelene.

Listele arhondologice publicate cu acest prilej rețin pe lângă numele comiților, respectiv pe cel al juzilor nobiliari, orice menționare în funcție a acestor demnitari (prin urmare, nu doar prima şi ultima); sursele citate sunt, cu puține excepții, documentele comitatense. Data emiterii documentului citat este urmată de referința bibliografică a ediției sau în cazul surselor inedite, cota arhivistică. Identificarea documentelor comitatense (până la anul 1526) s-a făcut cu ajutorul catalogului (DVD) documentelor medievale privind istoria Ungariei (Collectio diplomatica Hungarica. A középkori Magyarország digitális levéltára. Digital archives of medieval Hungary. DL-DF 4.3. Red. György RÁCZ. Bp. 2008). Identificarea exhaustivă a documentelor comitatense din perioada 1526-1541, în lipsa unor evidențe arhivistice 
centralizatoare rămâne o sarcină a viitoarelor cercetări. Din documentele emise de către autoritățile comitatense din Transilvania, anterioare anului 1542, s-au păstrat până azi mai mult de 500 .

Ultimul capitol conține lista alfabetică a tuturor funcționarilor şi în măsura în care acest lucru a fost posibil, identificarea celor menționați fără nume de familie. Totodată sunt inserate şi alte date, privind familia, titlurile onorifice purtate, posesiunile şi eventualele alte funcții deținute. (Datorită caracterului unilateral bine cunoscut al informaţiei documentare, datele înşiruite în acest segment al lucrării se referă mai ales la posesiunile avute de către cei care se regăsesc în listele discutate). Raporturile de familiaritate dintre comiți şi voievodul aflat în funcție au fost rememorate doar în situația în care o sursă documentară conservă în mod explicit memoria acestui fapt.

În evul mediu, vicevoievozilor Transilvaniei le era asociată şi funcția de comiții ai comitatului Alba. În arhondologia de față au fost incluşi doar acei vicevoievozi, în urmă cărora s-au păstrat documente emise în calitate de comiți de Alba.

Listele arhondologice publicate cu acest prilej sunt precedate, în cazul fiecărei comitat în parte, de referințe bibliografice la unele lucrări mai vechi de arhondologie sau geografie istorică. 


\section{ZUSAMMENFASSUNG}

Die vorliegende Arbeit enthält die archontologischen Verzeichnisse der sieben siebenbürgischen Komitate, die unter der Führung des Woiwoden von Siebenbürgen standen (I. Innen-Szolnok, II. Doboka, III. Weißenburg, IV. Eisenburg, V. Klausenburg, VI. Kokelburg, VII. Thorenburg) aus der Zeit vor 1542. Diese Verzeichnisse enthalten für jedes erwähnte Komitat den Namen des Gespans (comes, sowie des Vizegespans, wenn es einen gab), der beiden Adelsrichter sowie der Komitatsnotare; zu diesen Informationen wurden Details über die Zeit hinzugefügt, in der sie ihre Ämter ausübten. Die Archontologie des mittelalterlichen Ungarns, die Pál ENGEL für den Zeitraum 1301-1457 zusammengestellt hat (Magyarország világi archontológiája 1301-1457, Bd. I-II, Budapest, 1996), enthält auch Daten über die siebenbürgischen Gespane in der behandelten Zeitspanne. Die betreffenden Daten wurden wieder aufgenommen und um neue Einzelheiten (sowie den Angaben über die Adelsrichter) ergänzt.

Die Gespane der siebenbürgischen Komitate wurden vom ungarischen König und ab Anfang des 14. Jahrhunderts vom Woiwoden Siebenbürgens aus der Reihe der eigenen Familiaren ernannt; in der Regel entstammten sie siebenbürgischen Adelsfamilien. In den meisten Fällen bekleideten sie während ihrer „Laufbahn” keine anderen politisch bedeutenden Funktionen; von diesem Standpunkt aus hatten sie einen niedrigeren Rang als die Gespane der anderen Komitate (in Ungarn, in den Komitaten außerhalb Siebenbürgens und in Slawonien wurden sie vom König ernannt; sehr oft wurde das Amt von wichtigen Würdenträgern bekleidet).

Die Adelsrichter wurden in jedem Komitat vom Komitatsadel immer aus den Reihen der im betreffenden Komitat begüterten Familien gewählt. Ein beachtlicher Teil der Gespane und Adelsrichter gehörte immer wieder den gleichen siebenbürgischen Adelsfamilien an.

Die archontologischen Verzeichnisse vermerken, neben dem Namen der Gespane bzw. der Adelsrichter, jede amtsbezogene Erwähnung dieser Würdenträger (folglich nicht das erste und letzte); die angegebenen Quellen sind mit wenigen Ausnahmen Komitatsurkunden. Nach dem Ausstellungsdatum der zitierten Urkunde wird die bibliographische Referenz der Edition oder, im Falle der unveröffentlichten Quellen, die Signatur angegeben. Die Identifizierung der Komitatsurkunden (bis 1526) wurde mit Hilfe des Katalogs (DVD) der mittelalterlichen Urkunden zur Geschichte Ungarns (Collectio diplomatica Hungarica. A középkori Magyarország di- 
gitális levéltára. Digital archives of medieval Hungary. DL-DF 4.3. Red. György RÁCZ. Bp. 2008) vorgenommen. Die ausführliche Identifizierung der Komitatsurkunden aus der Zeitspanne 1526-1541 bleibt wegen des Fehlens einiger zentralisierenden Archivalien eine Aufgabe für die künftigen Untersuchungen. Von den vor 1542 herausgegebenen Urkunden der sieben Siebenbürger Komitatsbehörden blieben uns mehr als 500 erhalten.

Das letzte Kapitel enthält das alphabetische Verzeichnis aller Beamten und, soweit es möglich war, die Identifizierung jener, die ohne Familiennamen erwähnt wurden. Gleichzeitig werden auch andere Daten über die Familie, die erhaltenen Ehrentitel, die Besitztümer und gegebenenfalls die anderen bekleideten Ämter angeführt. (Wegen des bekanntlich sehr einseitigen Charakters der urkundlichen Information beziehen sich die in diesem Teil der Arbeit aufgezählten Daten vor allem auf die Besitztümer der in den behandelten Listen angegebenen Personen.) Die Familiaritätsbeziehungen zwischen den Gespanen und dem herrschenden Woiwoden wurden nur dann in Erinnerung gerufen, wenn eine urkundliche Quelle diesen Hinweis ausdrücklich enthält.

Im Mittelalter bekleidete der Vizewoiwode von Siebenbürgen gleichzeitig auch das Amt des Grafen des Weißenburger Komitats. In die vorliegende Archontologie wurden nur jene Vizewoiwoden eingetragen, über die jene Urkunden erhalten geblieben sind, die sie in ihrer Eigenschaft als Weißenburger Gespan ausgestellt hatten.

Die bei dieser Gelegenheit veröffentlichten archontologischen Verzeichnisse sind im Falle jedes einzelnen Komitats von Literaturhinweisen zu einigen älteren archontologischen oder historisch-geographischen Arbeiten vorangegangen. 
EME 
A címlapon a hét erdélyi vármegye 1348. május 10-én kelt oklevele (Magyar Országos Levéltár, Mohács előtti gyüjtemény, DL 30647)

A hátsó borítón Hunyad vármegye 1490. évi pecsétnyomója (Szinte Gábor: Hunyadmegye czimere. In: A Hunyadmegyei Történelmi és Régészeti Társulat Évkönyve, 8/1893-1896. Kolozsvár 1897. 27) 


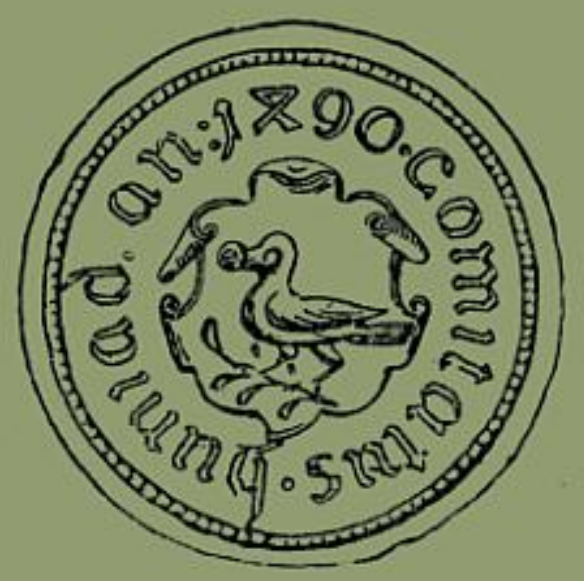

$A z$ erdélyi vármegyék középkori archontológiája a hét erdélyi vármegye (Belsőszolnok, Doboka, Fehér, Hunyad, Kolozs, Küküllö, Torda) ismert tisztségviselőinek - az ispánok, a megyénkénti két szolgabíróés a vármegyei jegyzőneveit és hivatalviselésük időhatárait tartalmazza. Az ispánokat az Árpádkorban a király, a 14. század elejétỏl az erdélyi vajda nevezte ki tisztségbe, az ugyancsak a 14. század elején feltünő szolgabírákat pedig (valószínűleg évenként) az egyes vármegyék nemessége választotta. Az összeállítás legfontosabb forrása a hét vármegyei hatóság által kibocsátott oklevelek; az 1542 elöttiek közül több mint 500 maradt fenn napjainkig.

ISBN 978-606-8178-08-0

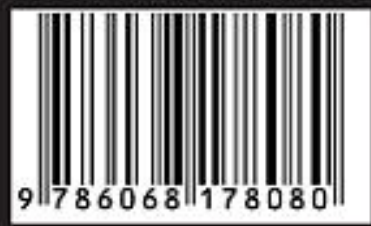

